\title{
THOLAS CROLIELL
}

ASPECTS OF HIS ADNIINISTRATIVE MORK.

\author{
G.R. Elton
}

Thesio

submitted for the degree of $\mathrm{Ph} . \mathrm{D}$.

in the Univeroity of London

1948 


\section{ELTON}

Thomas Crorarell: Aspects of his Adminiatrative Work.

(Brief summary of thesis).

The thesis is concerned with these points:

(1) The features of Cromoli's administration.

(2) The light they throw on his personality.

(3) The place of his rule on the history of administration. The introduction defines the linits set and reviers the oources. A first chapter discusses Cromwell's rise to power, showing that he rose by degrees and as an adrainistrator, his arrival to power being marked by his obtaining an office. Chapter two invegtigates his chief lay offices (master of the jerrels, clerk of the hanaper, chancellor of the exchequer, principal secretary, master of the rolls, lord privy seal), dealing with their functions, their importance to Crontrell, and the effect on them of his tenure. His choice of offices is seen to have been determined by a desire to control the financial and secretarial organisations, and these are then discussed. In the former, note is taken of Cromwell's personal treasurership which mede him the nain disbursing officor for the king's money, of hts relations with the chamber machinery whose decline was die to hirn, and of the agencies established to administer the new revenues. Then cone his dealings with the various secrotariats: "orders thich tightened up the organisation of the signet office; a stricter definition of the use of the signet and privy seal in the process of a grant under the great seal, and Cromela's evasion of his orm rules; his personal activities as secretary and lord privy seal; his use of Thomas VTriothesley as "undereccretary" in charge of the clerical departments. The last chapter investigates Cromoll's relations with the council; he is seen to have encouraged conciliar government and himself to have organised the privy council proper as oarly as 1536. The conclusion attempts to account for the fact that in his adninistration Cromeli seems to have been guided by contradictory desires (to organise bureaucratically, and to evade bureaucratic organisation in the intorests of personal ascendancy), and to assess his place as the founder of modern government in England. 


\section{BEST COPY}

AVAILABLE

Poor text in the original thesis.

Some text bound close to

the spine.

Some images distorted 


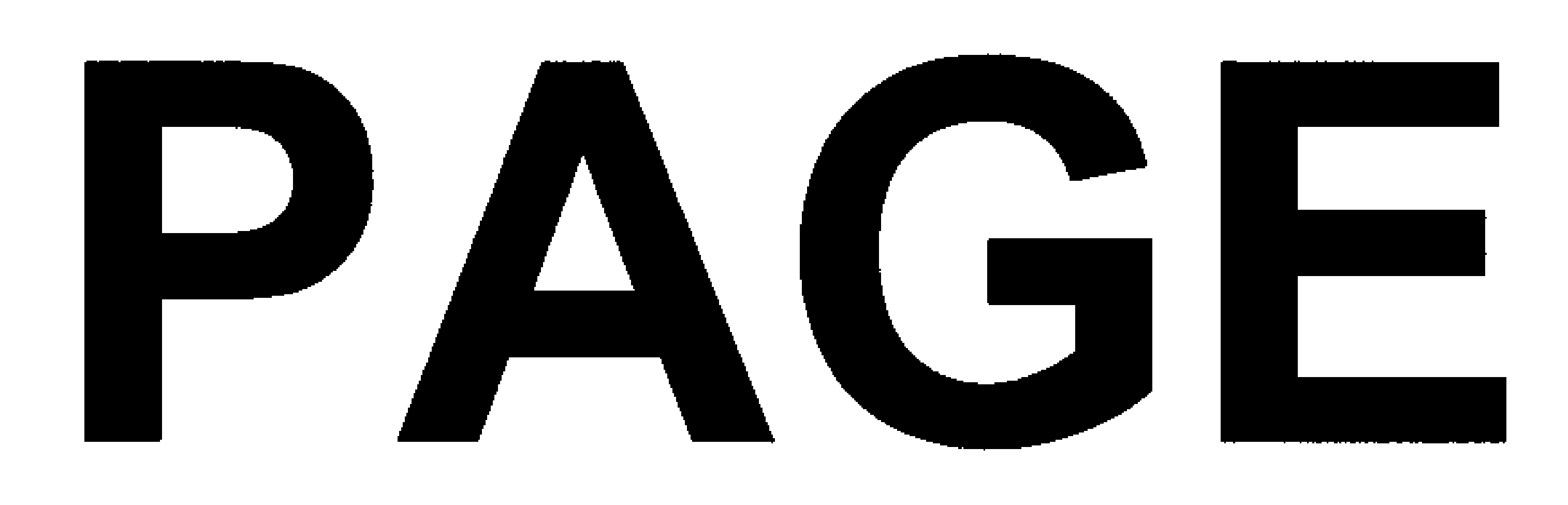

NUMBERING AS ORIGINAL 
THOMAS CROMUELL

Aspects of his Administrative Work 
Table of Contents.

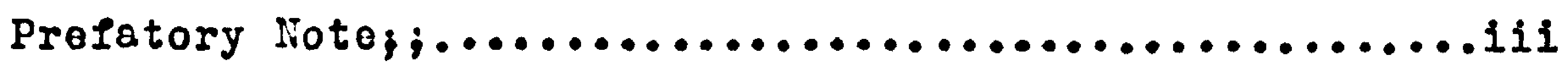

Introduction: Scope and Sourcoo of this study.......... 1

Chapter 1: Cromell's Rise to Potror................. 12

I. The llanner of his Rise (p.12)

II. The Stages of his Riso $\left(p_{0} 43\right)$

Chapter 2: Cromell's oflices....................68 I. Haster of the Jowelo $(p .64)$

II. Clerk of the Fianaper $\left(\begin{array}{l}p .72 \\ \text { I. }\end{array}\right)$

III. Chancellor of the Exchequer (p.86)

IV. Frincipal Secretary $(p .101)$

$V$. Master of the Rollo $(p, 120)$

VI. Lord Privy Seal (p.136)

VII. The Significance of the offices (p.151)

Note: Lisater of the Fards ( $p .156)$

Chapter 3: The Financial Adminiatration...............161

I. The Financial Administration in 1531 (p.161)

II. Cromell as a Treasurer (p.174)

III. Crowwell and tho Chamber $(p .201)$

IV. Cromell's New Lachinery $\left(\begin{array}{l}\text { p.234) } \\ \text {. }\end{array}\right.$

V. Tho Administration after Cromtril's Reformo (p.286)

Chapter 4: The Clerical Organiastion.................284

I. The Signet and Signet office (p.284)

II. The Privy seal (p.316)

III. Crommeli's Personal Activity (p.332)

IV. Thomag Vriothesley, Cromveli'g "Undersecrotary" (p.341)

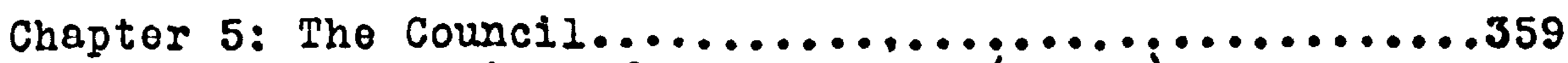

I. The Council beforo Cromwell (p.359)

II. The Council under Cromell (

III. Erowtell and tho Council (p.385)

IV. The Rise of the Privy Council (p.409)

Chapter 6: Cromoll's Place in the Hiotory of.........443 Adminiatration

Appondix A: Transcripts of Documents..................457

I. The financial machinery when Cromell came to power (p.458)

II. "Account $A$ ", a specimen of Crommell's accounts $(p .463)$ 
III. The earliost aurviving warrant for paymont addresood to Cromell (p.466)

IV. Crommell'g ordorg for the aignet office (p.467)

V. The appointmont of Thomao Derby as clork of the council (p.469)

Appendix B: Bibliography

I. Lanuscript Sources $(p .471)$

480

II. Printed Sources $(p .474)$

III. Secondary Works $(p .475)$ 


\section{PREFATURY NOTE.}

The following uoureviations have beon usod:

A.P.C. - Acts of the Privy Council.

B.... - iritisis ingeun.

Bul1. - Bulletin of the Inctitute of Historical Rosearcin. Cal.S.P.Doin. - Calendar of Stato Paners, Domestic. Cal.3.P.For. - Calendar of State Papers, Foreign.

D.N. i. - Dictionary of iNationaI Biograpliy.

E.H.H. - English iligtorical Roviow.

if.k.c. - Historical ianuscripts ioimisoion.

L.J. - Lords' Journals.

L.P. - Lotters and Papere, Foreign and Domertic, of the Reign of lienry VIII.

P.R.O. - Public Record Orfice.

Span.Cel. - Calondar of Stato papors, Spaniah.

V.C.H. - Victoria County History.

Ven.Cal. - Calondar of State Paperg, Venetion.

Figures aftor roferences to L.P. and Ven.Cal. aro to numbers of documents, that being the prictico in the respective indexes; in all other cases they are to pages. Finere the or ginal of a docuinent calendared in L.P. has jeen consulted the reforence to the manuscript is usueliy given, folloved by the reference to L.P. For the sake of brevity, P.R.O. manuscripts are quoted by the call number there in use; a key to these vith a full description of the classes winich they roprowent rill be found in the bibliography (App.B, Section I). In transcripts, abbreviations have beon extended and rodern punctuation has been adopted, with the result that capitals have occasionally been put where there are none in the original; othertige the apelling of the manuscript has alway been rendered exactly. Reierences to printed works in the footnotes are usually given in more or less abbreviated form; the complete description vill be found in the bibliography. 
Introduction. SCOPE AND SOURCES OF THIS STUDY.

"In the whole line of English statesmen there io no one of whos we would willingly know so mach, no one of whom wo really know so littlo, as Thomes Cromwell."1 Indeod, although volumos have been writton on Henry VIII, on Wolsoy, Gardiner, and Cranmer, although whole shelves could be filled with the literature that has grown up round Thowas ifore, out knorrledge of the man to whom Groen ascribed the Reforwation and whom another historian called the creator of the Church of England ${ }^{2}$ is still scanty. The standard biography contains a collection of his letters, with an introductory "Life" which does no more than give a résumé of the political ilistory of the period with Cromell in the centre of the stago. 3

Thug seventy yearo after Green doplored our ignorance, we wust still ask ourselves what sort of man Thomas Cromiroll Was. Tho word that springs to the mind, the rord that has most comonly been used to describo him, is "dachiavellian".

1. J.R.Greon, History of the Engligh People (1878), ii.142. 2. J.A.Froude, History of England, iii.339.

3. R. B. Lierriman, Life and Letterg of Thomas Cromell. Quoted hereafter as "Serriman". 
The picture usually left with us is that of a very diligent man, subervient to his overbearing master, clerer and unscrupulous, cruel and ruthlese, a spider in his net, a vicious enemy to the gracious light of More snd the gentlo piety of bishop Fioher, not even inspired by the zeal of a now faith. Apologiato may diacover extenuating featuros. He was, we are told, a sociable companion; he novor lorgot old Iriends; he lacked all trace of vindictiveness. Sometimes we are reminded, by way of excuse, that wore persecuted heretice and that Firher engaged in troasonable traflic with the omperor's ambassador. But in truth, this is no picture. It is the caricature of emotional partisanship or of inoufficient knorledge, and the use of a convenient, though meaninisless, label indicates the depth of the appreciation attained. The men who know him in life have taken their knorledge with thew. ${ }^{1}$ No faithful son-in-law or gentleman usher was inspired by Thomas Cromell to leave a memorial to one who was either a great stateswan or a magnificently great scoundrel.

We shall thorefore havo to seek him in the monument which he erected for himself, in hio work. For something like ten years he stood near or at the centro of alpalss.

1. Though Nicholas Harpsfield wight apparently have left us some revealing anecdotes told by one who kner hin very well (cf. R.W.Chambers, Thomas wore, p.292). 
His corrospondenco, confiocated at hio Lalk, ourvived in fifty-tro volumes, until it was brokon up and robound with the other state papers of tho roign. The history of the timo, the rocords of his doings, ought to provide the clueo which tro are oeeking. Some, we have soon, have made him the moving spirit hehind the Rolormation. On the other hand, Profesoor Pollard could tell the story of Honry VIII with practically no major reference to Cromell. There is a passage in bis book which exemplifies his attitude. ${ }^{1}$ Then the Reforwation really got under way, ho tells us, in 1532-3, everybody opposed ifonry's policy. Firm oupportera of the divorce began to waver when they gaw where things were going. He gives a fow nameo - archbishop Loe, bishops Tunstall, Gardiner, and Longland. "It was tho King, and the King alone, who kept England on the course which he had weppod out." There is no mention of Cromoll. The policy of the $1530^{\prime} 8$ was Henry'o om and no-ono olse had a hand in it. Werriman, looking at the watter from the other side, ascribed every act of policy to Cromwoll, leaving Henry in the cold, and we aro left to wonder whose the wind was that directed the course of tho Reformation. Biographers will almayo exalt thoir subject, and it way bo unprofitable to engage in a controversy which way for ever remain undecided.

1. A.F.Poliard, Henry VIII, p.306. 
King and rinister are so inoxtricably ontanglod with oach other, and the evidence is so insufficient, that overy answor will, in tho lagt resort, reisain a porsonal vordict. In any caso, it is not intended hore to onter that dusty arena.

Nevertheless, oince the groateot modern historian of this period lelt justifiod in practically ignoring Cromell, it may be porissible to rovier quickly the reign of Henry VIII, in order to see whether there is not good roason, on a general view, for ascribing importince to him. Henry's reign. Lalle into three parto. Until 1529 Wolsoy ruled and Henry remained in the background. Tho period was one of wuro and brilliant diplomacy. England achierod a now position of exinence in Europe, and the great cardinal seeled at tives to arbitrate in the councils of princes. Hovever, the glory was a sham and Wolsey's magnificont building lacked foundations. With his fall the socond period of Honry'o reign began, the poriod of the break with Rome and the subjugation of the English church to the royal power. It was in the $1530^{\prime} \mathrm{s}$ that the pormanent achievewents of the roign were produced, and it was during these years that cromell stood beside the king. After 1539 wo can detect the third period, one of rapid decline and retreat. Indeed, it is as though the doath of Crowtroll romoved the 
iil inopring of the machinory. Profesnor Pollard reste his interpretation of tho roign on the paychology of tho king. Ilonry, he waintains, matured slowly, and it was not until 1529 that he caile to his lull stature as a statosuan. That may be so, but are wo to see no sianificance in the fact that rhatever of lasting value was done in Enfland undor Henry VIII was done while Crowwell was in power? Why, for instance, was it only after 1540 that England wont to war again, that the coinage was debased and the monastic lando were squandered? Does not the drift into lamentable Lailure, tine general disorganisation, which characterise the last seven years of ITenry's lifo, sugoest that thore is sorrething wrong vith an interpretation vinich purhos Cromell to the back of the stage?

These are large questions, and they cannot recoive thoir answer rithin the limits of this study. Cromell the Liamer of the Lonks, Crommell the policy waker, Cromrell the political thinkor, Cromoll the financjal and comorcial genius, Ell theso and other facets of his fagcinating personality we shoil have to ifnore. Doubts may for ever be raisod whother it was he or the king who guided the course of the Reformation, but there is one aspect of his work which is wost clearly and fully his. The surviving ovidence leaves no doubt whatever that it was he who san to the administration 
of the kingdom. The dotalls of govornient, the day-to-day roris of the exocutive, tho control and reform of the administrative rachine, these rore in his hands. Thousande of lotters, warrants, arafts, accounts, bearploquent vitneso to that. lior has this aspect of his work recoired tho attontion and detailed study which it deserves. Fow mon can ever have identified their lives so corpletely wi.th their public work, and Cromell the adranistrator may provide us with meny a clue to his true pereonality.

There is snother, loss biographical reason, why his administrative rork ought to be studied. Reform of the adrinistrative machinery ras one of the outstanding features of the Tudor contury. Few things are more striking in a survey of the public records of England than the manner in which many redieval series run down to about the time of Edvard IV, while most of the modern series do not begin until the last thirty years of Elizaboth's reign. ${ }^{1}$ The intervening hundred years are filled with a turmoil of pragmentary and sometines ill-assortod ovidence through which there man occagional otrands of the dying past or the germinating future. The state of the rocordo, 88 is so often the case, reflects a development in the practice of govern-

1. This is particularly true, e.g., of the exchequer and the signet, wuch lese so of the chancery which presorved wany of its medieral series though it lost some and added others. 
ment. Whateror crodit way bo givon to the Yorkiot kings and we are hoginning to roaliso more and more that tho Tudors did not start from scratch - the plain fact is that Ilonry VII ascendod the throne of a medievally governed kingdom, while Elizabeth handed to hor guccosior a country administered on modern lines. A lost oignificant history of the contury could be witten round the work of its groat adrinistrative rolormers - Henry VII, Cromell, Winchester, Burleigh, and many lessor names.

This is, then, a study of the administrative work of Thomas Cromoll, but as the title indicates jt will deal with certain selected aspecte only. Cromrell's work affectod so wuch of the country's history, covering as it did every Ephero of govornment activity, that a study of the wholo of it would involve us in tho viriting of a full biography as well as in detailed investigations into a dozen different fields. That could clearly not bo dono within the limits of a thesio. It thus becaine nocessary to make a choice, and the first and most obvious dividing lino was that botween lay and ecclogiastical aduinistrations. No account is hero taken of tho latter: we do not propose to deal with Cromwell's work as the king's vicar-general and vicegerent in spirituals, with tho dissolution of the monasteries excopt inesmuch as it was a Iinancial roasure, or with the admin- 
istrative side of the rubjugation of tine church to the cromn. Te aro only concornod with tho fiold of lay adriniatration. Evon this proved so large that further selection bocame unaroidablo, but it ras poss:blo to select a fer aspects of administration which formod a roasonable whole.

Starting from Cromsil's rise to power, a rise which took place within the adujnistrative machine and was marked by his obtaining office, wo shall be led to a diecussion of the six chiol lay offices which he held. The significance of theso officos will take uo into nn investigation of the tro indisponsable pillars of every adninistration, the financial and clorical organisations, and finally ro shall havo to deal with the coping-stono of the administrative structure, the king's council. These are the fundaisental aspocts of Cromell's administration, and his work in these sphores is essential for an understanding of the wan and his idoas; other points of considerable interest, such as the royal household, local governmont, the adrinistrative use and control of parliament, have had to be omitted as distracting Irom the main theme. A whole soparate study could and should be vritten on aduinistrative projects and ideas, both Inside and outside the government, but this could obviously not be included within the linito of a thesig.

To turn to the sourcos which havo been used. Evoryono 
who works on the history of the first half of tho oixteonth contury mast otart by acknowlodging his dobt and paying hio tribute to that ragnificont ooriog of calondara, the Letters and Paperg, Foroign and Domestic, of the Roign of Honry VIII. Tho editoro havo anticipatod much labour and drudgory, but in ranoacking the Public Rocord Offico and Brition Wuseum they have made tho task of linding anything roally now, at loast in London, very difficult indoed. Although much reliance has, of course, boen placed on tho calendar, an attompt has been made to soo orory document of importanco, overy document on which a crucial argurent might dopend, in the original; the manuscript has also boen consulted where the abstract in the calendar seomod doubtful or ambiguous. At the same time it has been necessary to glean where the editors of the calendar had reapod; on tho one hand, large numbers of documents of poosible relevancy have boen gono through, more often than not without positive result, and on the other recordo not used in the calondar havo been exploited, as for instance many rolls and accounts in the exchoquer. A good deal of manuscript material not printed evon in abstracts has therofore boon uood, but the nature of the rrork and of the sources rakes it impossible to deocribe any largo clasges as particularly important. All has had to be griat to this mill, but a good deal had to be thrown 
array as usoleos. A list of all the material which has actue.Ijy contributed to the writing of this atudy wili bo found in the bibliosraphical appondix, and where it seomed advisable individuel classes of manuscripts have been discussed in the relevant placos in tho text.

Apart Irom the important articlos by Profoisorg Pollard and lierton, and the work of Dr. Dietz on financo, littlo has been written on the administrative history of the time. I have had the bonefit of discussions wi.th Profossor W.C. Richardeon, of the Louisiana State University, Those forthcoming book on the financial machinery of the early Tudor period is bound to mark a nor stage in discussions of tho subject, and to provido tho much nooded larger picturo into wh:ch such more detailed studies as those in Chapter 3 of this thesis ought to fit. That chapter mas written before I first aar Professor Richardson whose largor conclusions I was glad to see were in agreement with my orn. other works have proviced the necessary background and setting for other administrative problems; they are noted in tho bibliography.

The moterial has variod in usofulnegs and charactor for each of the oucceeding chapters. Cromoll's riso and tho story of the council have had to be vritten almost entirely Irom sources calendared in the Letterg and Panerg, with 
frequent reforencos to the originals, while Chaptero 2 and 3 have benofited mont from inveatigationo into materiols not used bofore. The survey of the arailablo sources has often takon me outaide the narrow limits sot for this thesis; it has reverled, for instince, how much might be done on the srowth of legiglation and ita shaping by Crowvell whose handwriting appoars on so many drafta. Such mattora, as well as the dotails of his momoranda and notes, are all almost untouchod as biographical matorial and as moans of illuminating tho inner history of tho timo; porhaps it will be posgible to make more of them in the future. In the neantimo it is hoped that tho investigations of Cromoll's offices, of tho financial and clerical organiaations, and of the council, will throw somo light both on Crowroll porsonally and on tho history of the changes rhich produced the modern adrinistrative system in ingland. 
Chepter 1.

CROUTELL'S RISE TO POWER.

I. The Lanner of his Rise.

Wolsey was deprived of the great ncal in Octobor 1529; by the beginning of 1533 Cromroll was, in the words of tho imperial ambassador, the man who had "most influonco with the king". 1 In the opace of three yearo tho servant of the fallen cardinal had attained to a degroo of influenco Which differed littlo from that wolded by his old master. What is in doubt is not tho achiorement but tho way of it: Crommell may havo gradually climbod to oupremacy, as Carondish suggeste, 2 or, as other moro or 108 contemporary writers say, he may have presented tho king with a full plan for the divorce and the break with Romo alwost as soon as he ontered his service, thereby imediately becowing the power bohind the throne. Profossor Werriman took tho latter viow. 3 Tho methods employed in carrying through the Relormation, tho contrast with Wolsey's policy, and his conoequent bolief thet we mast supposo a now adviser in order to explain the nor line of action, convinced him that what he called "the siniater genius of Cromoll" was at rorks

1. Span.Cal. 1r(ii).644.

2. Covondigh, Wolgoy, pp.1981.

3. Merriman, i.8911. 
bohind tho ocener. He admittod that thore is little concroto ovidence for auch a vion but sugge日ted that it was in Henry'g interest to koep his minioter in the background and assume responoibility himoell, thus using tho prostigo of the royal name to protect moasuros "universally unpopular", and incidentally also to ohield Croweld from tho pooplo'o rovenge.

Such reasoning clearly depondo on a personal estimato of equally personal factors in the story. The biographer of Henry VIII held a different opinion. To Professor Pollard tho eccleaiastical logislation of the yoars 1530-34 was due to forogerablo and long foresoen circumstancos and developmento. 1 He shored that Merriman's guggestion of a deliberate suppression of Cromell'o part in affairs will not stand up to investigation: it ras not Henry's "habit to assume a responsibility which he could devolve upon others", 2 and indeod it seems hard to say - as Pollard says - why Henry should have found it moro difficult to protect his minister in 1530 than in 1536. Pollard came to the conclusion that "Cromell, in fact, was not the author of that policy [the Reformation], but he was the most efficient instrument in ito exocution". Similarly, Dr. Gairdner

1. A.F.Pollard, Cranmer, pp.66ff. and note on p.68. 2. A.F.Pollard in Enc.Brit. (14th ed.), vol.7, p.500a. 
affirmod that Cromwoll playod a oubordinato part at firot, being "the more tool of the court" and, in the years under consideration, but a minor member of the council. 1

Wo mast turn to the oridence on which these different viers were based. Merriman's opinion could claim tho authority of Chapuya, the imperial ambassador, 2 of Cardinal Pole, 3 and of John Foxe, 4 all of mhom make it appear that Crompell entered the royel service and achieved pre-eminenco at one bound as tho reault of one interview mith the king at which he submittod a plan for solving Henry's diflicultios which ras immediately accoptod. Thoir stories, howover, can be crodited only if they are reasonable in themselver and agree with other known lacts, and these requiromente nono of them fulfil.

Chapuys relates how soon after Holsey's death Crompell was involved in a quarrel with Sir John Fallop and therefore sought the king's protection. "He asked and obtained an audience Irow king Henry whow he addressed in such llattering terms and eloquent language - promiaing to make him tho richest

1. J.Gairdner in D.N.B.g V.198b-199a. CL. A.F.Pollard, Wolney, p.340: "There Jas an interval... between Wolsey's and Cromwell's predominance; and during that interval....iorlolk and Gardiner rather than Cromwell and Cranmer were tho adviaers on whore Henry relied."

2. Span.Cal. $\nabla(i) .5681$ ( (L.P. ix.862).

3. Reginald Pole, Apologia, pp.66ff.

4. Juhn Foxo, Acts and lionumonte, $\nabla .36611$. 
king in the rorld -1 that the king at once took him into his service and made him councillor, though his appointment was kept secrot for four montho." This can hardly be true. Wen pore sworn of the council, that is, they took an oath before their fellows which made thoir appointment manifost.2 Loreover, wo knov that if Chapuys is right about the timo of the interviow Cromproll'a councillorahip dia not remain a oecret for four montho. Noloey died on 29 Norember $1530 ; 3$ thus we should have to assume that Cromoll's appointwent did not become known until at the earliest in April 1531. Yot on 10 January 1531 an obscure priest of York who was certainly not in any of the king's secrots addregeod a lottor to "Mastor Cromwell, one of the kinger most graces Counsaill", 4 and letters to Cromisell as councillor become quito erequent after that. Chapuys wrote his account in 1535 by which time Cropwoll was undoubtedly tho king'o loading minioter. He relied on information which, howerer good, could no doubt bo wrong at times, and he could not have loarnod of what happonod is

1. Thus Span.Cal. The original French says moro reasonably that Cromrell promised Henry "de le lairo lo plus richo que oncques lut en angleterre" (uerriman, $i .17$ ).

2. H.S.Holdsworth, Higt.of Law, iv.o4; J.F.Baldwin, King'g Council, pp.71,346,354 ("a rell-undergtood featuro of the constitution" by the time of Henry VI). Fortescue thought the oath an essential feature of the council (ibid., p.207). The owearing-in of councillors is noted in the liber intracionum of tho reign of Henry VII (ibid., p.347; cI. E.H.R. xxrvil, pp.3561.).

3. A.F.Poliard, Wolgoy, p.301.

4. P.R.0.SP $1 / 65,1.60$ \{.,. .38 ). 
at the oupposed interview with any cortainty except Irom Henry or Cromell, neither of whor rould have told him thio particular atory. In all likelihood ho obtalned the material for his roport Irom more than one source, throming together in one dramatic otory erents which had taken place at different timer, and mixing in as well common reporte and peroonal belielo which may not have been anywhero near the truth at all.

Eren less credence can be placed in Pole's account. Ho tells how Cromerell, as the "dessenger of Satan", came to the king and persuadod hiw to tho ovil way in an intervien at which he oubmitted the whole of his future policy. Easily convincod; Henry "oino mora dedit ut inter intimos ot primarios conciliarios cognosceretur illen.1 This story, in Prolessor Pollard's mords, hak been too readily acceptod, 2 though its reliability was torn to ohrede by Profoseor Van Dyke who proved beyond doubt that - to put it moderately Pole mas not incapablo of error. 3 Friting some nino years aftor the erent and influenced by all that had happened since he loft in Engzand in 1531, Pole not ourprisingly ascribod both to himself and to Cromrell such viers and insight at so early a dato as 1529-30 as ought in truth to have been sproad

1. Pole, Apologia, p.125.

2. Enc.Brit. (44th od.), v01.7, p.499b.

3. Paul Van Dyke, Renascence Portraita pp.37711. (appondix on "Reginald Polo and Thowas Cromelin"). 
orer the rhole intervening period. 1 He himoell affirmo only that the oentimente which he ascribes to Crownoll aro such as Cromell truly hold, adding that ho has hoard thoir like at divero times from Crompell and his friende. He doos not appear oo concorned with the truth of tho oetting which he has given to the supposed opeech. 2 He may have reported rightly some of the things thet occurred, bat wo cannot truat him in his account of how things happenod.

Foze, too, has an interviow. He saye that it was brought about by "Lord Russell, earl of Bedford", anxious to repay Cromrell for saving his lifo at Bologna whon Russell was there on the king's oervice. Russeli - not elevated to the peorage until $1539-3$ was at Bologna in 1525 whon thore is ample evidenco that Cromwell was in England engeged on Wolooy'o busines8.4 Crourrell, Fore relater, rent to the king armed rith the biohops' oath to the popo in order to prove his allegations againgt tho clergy, and left with the king's aignet ring to go dom to Convocation and scare the biohopo out of their wits. If this nere tmo, the silence of contemporary accounto of tho proceedings in Convocation would indoed be surprising. The whole story is unconvincing, and

1. Ibid., pp.3371., 3971.

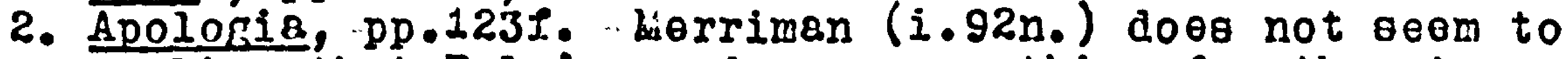
roalioe that Pole'o rordo prove nothing for the story of the intorvier, whatovor light thoy way throw on Crowtroll'o politicel opinions.

3. L.P. xiv.I.477.

4. D.1H.B. $x \nabla i i .445 \mathrm{~b}$. 
Fozo'o reliability is not increased by his otating that Cromwell ras knighted and made mester of the king's jorrol-houge "the noxt yoar" (1531), and admitted to the council. In fact, Crowroll was not knighted until 1536,1 on the occasion of his elevation to the peorage, and was officially otylod "armiger" in September 1532. ${ }^{2}$ Hio appointmont as master of the jerrelo was dated 14 April 1532.3 Horeover, Cromoll was of the council by the beginning of 1531, Noll bofore ho attained any other position. We may discard Foxe as an authority on thio matter.

Howerer, it is of some iraportance that all those writers rere convinced that Crompell had some one important intervier with the king, an intervier of decieive influence on his later coseor. They ray have boon right to this extent that Cromwell took overy opportunity to see the king and ecquire his confidence, though they were hardly right in assuming that all the rest follored frors one such meeting. Cavendish rentions a number of intervierr, though be did not ascribe to them any such startling and 1mmediate consoquences. 4 According to his version Cromroll had occasion to 800 the king repeatediy because he had "the ordering and disposition of the landes" of Tolsey's colleger, for which reason he acquired

1. N.A.Shaw, The Knights of England, ii.50.

2. Rymer, Foodera, xiv.439. 3. I. . P. V. $978(13)$.

4. Cavondioh, Folooy, p.199. 
much importance in tho ejos of courtiors hungry for thoso lands, and "grewo continually into tho kingo lavour". "Tho conferenco," as Cavendish puto it, "that ho had therein with the king, caused the king to ropute him to bo a very wios man, and a meto instrument to sorvo hie grace." That Cavendioh moant by confercnce is clear from whet went bofore: ho was thinking, not of one mooting, but of Henry and Crowwell conotantly conforring togother on the dioposal of those lendo. Perhaps it is in this liberty and frequency of accers to the royel person that wo cust soek the origin of the "intorviow" atory.

Evidence in farour of the vior that Cromoll roge gradually in the royal service is to be found in tho record of his day-to-day activitios from tho fall of Holoey onwarda, a record protided by the extant portion of cromell'o correspondence. There is no roason to suppose the collection of incoming lottero seriously deficiont in any part, though it 18 unfortunate for us that the business mothods of the time had not yot adrancod as far as tho kooping of copies of out-lettors. Mo are told that "Henry and Cromwoll mado erery effort to concoal their traces; scarcely any information can be gleaned Irom their correopondence". 1 It would heve been woro correct to osy that thero is hardly any

1. Lerriuan, i.89. 
correspondence betroon them extant for this time. Wo poosoge three lottere from Cromroll to Henry and none at all from llonry to Crompell for the joars 1530-32, and these threo lettere belong to the last eight months of 1532 whon Cromwell had Eono far in his rise to porrer. ${ }^{1}$ Loroover, these lottero do not oupport Herrimen's contention, for in each of them Cromroll reported in dotail, and without attempting to concoal any traces, on various administrative activities in which ho ras engaged: news recoived from abroad, the affairs of an attaintod traitor, the making of jorrelry to tho king's dosign, a caso concerning land in which tho king had an interest. Tho lact is that in theoo early yearg cromoll know that hio influence dependod on proximity to the king, so that naturally there was rarely any correspondence betroen them. On the other hand, there io no reeson whatsoever for confining ourselves to the letters which Cromwell and Henry may or may not heve written to each other. From what eurvives of Cromerell's papers it is easily discovered what ho ras doing at any given tiwe, though it may not always be possible to say with certainty what he was not doing.

Whatorer hio position at court may have been, from Wolsey's fall to Volsey's death his main busineso was with and for Wolsey. Though intent on porer, he epent much time on

1. I.P. F.1055, 1092, 1298 . 
the affairs of a fallon man; while it is true that ho used Wolooy'o business to adrance bimself, it must also be oaid that thero seome to havo been a otrong trait of loyalty in him. As early as Norember 1529 he oam the king himeolf sbout Wolsey's licence to go to hid province of York and transmitted Henry'o disploasuro at a delay in the conferment of a benefice. ${ }^{1}$ All through the year we find those numerous appealo from the fallen mastor to the riaing servant which have caused so anch moral censure. ${ }^{2}$ For the first lew months Cromell was Wolsey's only hope. 3 He was to geo to Volsey's pardon, to achiere the restoration of Winchester, to intercede with the ner powers - the Boloyns and Norfolk. 4 If his vieito to Esher lacked the regularity which geomed desirable to the cardinal'g oick and worried wind he ras agsailed with abject and pressing entreaties.5 He still drafted Wolsey'o lotters to the king. 6 He tried to more Gardiner, apparently to lukeriarm for the faithful sadler, to help his old master, 7 though Holsey himself spared no pains to enlist the man who as the king'o secretary might be thought to have been in a better position to assiet than Cromrell.8 In omall things as in big Crowell was Wolsey's stand-by this year. He was

1. L.P. Add. 665 .

3. L.P. iv. $6076,6098,6114,6181$.

4. Ibid. 6222; 6181,6226; 6076,6098,6114,6226,6262,6554.

5. Ibid. $6114,6203,6263$.

7. Ib1d. 6112,6202 . 2. E.g., Merriman, i.73. 6. Ibid. 6467 . 8. Ibid. $6202,6224-5,6260-1,6299$. 
to obtain medical aid, ho was expocted to look aftor a horoodeal and after money, he settled Woleey's billo and handled hio library, ho drnfted a privy ooal to socure Nolsoy hospitality on his ray north, he ras asked to look into somo trouble among the tenents of Wolsoy's hougo at Battersea, he rag deeply involrod in the complicated story of Thoma Strangways' suit for $£ 700$ againot Wolsey. 1 In othor vords, he rag otill, es he had been, Foloey's sollicitor.

Wolsey'a imediate troubles wore by no meang all the business which his fall put in the way of his servant. Folsey made some grants of land to influential men at court, and the negotiations concerning them were in Crommell'o hand. It is not improbable that he had porguaded the cardinel to make these grants; at any rate, he made good use of them in advancing his orm importance, a lact alroady realioed by Cavendish. ${ }^{2}$ Then the king granted the keepership of Farnhem Castle, part of Folsey's surrendered possessions, to lord Sandes, a grant which noeded Toloey's seal and consent, Cromwell was approached about the drafting of the king's letter and for information where the seal of Winchester ras; ${ }^{3}$ the advantages of all these activities were shown in the letters of thanks which the recipient, lord chamberlain of the house-

1. L.P. iv. 6151, 6249,6108,6436,6186(ii), 6390,6294,6494,6582-8. 2. Cavendioh, Holsey, 1981.; Lerriman, 1.711.

3. L.P. 18.6420 . 
hold, wrote to Cromell.1 The businese connected with these patents of Folsey's continued to occupy Cromprell right through July, August, and September 1530.2

In addition to all thio varied work there ras another big part of the Nolsey legacy: the colleges at 0xford and Ipswich required Cromrell's attention. He had superintended their foundation and the disoolution of the monasteries used to found them. 3 The cardinal'o fall and his praemunire put them in a very difficult pooftion, but their tie日 with the cardinal's moot prominent agent were not eevered. By 9 Norember 1529 Milliam Capon, dean of the Iparich college, was in despals because be did not knor who ras actually in control of his affairs, Holsey or the king, and as a matter of course he appealed to Cromell; ${ }^{4}$ Cromwell was imediately informed when the king's comissioners came to take an inrentory and to depart with a portion of what they found, 5 he did the college's legal business. 6 For the oxford college he continued to oupervise the collection of rents, and his serrant Nilliam Brabazon made the rounde at the Buckinghamahire monesteries of Tickford and Ravenston, ${ }^{7}$ both of which belonged

1. Ibid. 6435,6460 2. L.P. Add. 693-4,697.

3. $\frac{\text { L.P. }}{444}$ ir. $989,1137(2-20), 3360,3461,3536,4117,4229(9), 4230$,

4. Ibid. 6055 .

5. Ibid. 6061.

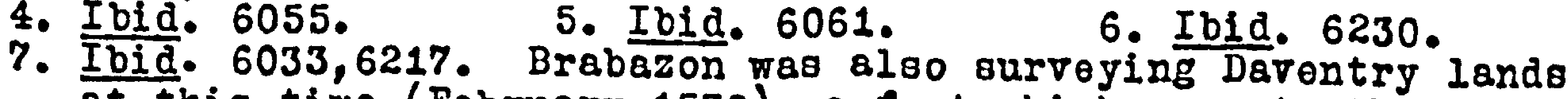
at thio tine (Fobruary 1530), a lact which sugests that Cromvell continued to look after some of Holoey's om property. Daventry was still in Folsey's poseession in March 1530 (ibid. 6863). 
to Cardinal'a Collego. 1 He aogiotod in tho salo of goodo bolonging to the collegor.2 None of this activity, horover, indicates that Cromwell was in any way connected with tho government. Ho had acted midrife to the college at Iporich, yet when the king sent a commigeion there Cromell was not on it and had to bo told of ito activities. Like all the other business which we heve so far mentioned, this work came to him as a consequence of his service with Folsey.

This conclusion is confirmed by tho colleges' subsequent history. Their position became criticel about tho middle of 1530 when the king turned his attention to the problem of their future, and when it seomed for a time as though both might be dis801red. Wolsey was in despair, and appealo wont out to Gardiner, to the chief juatice of the king'o bench, to the attorney-genoral, to tho king himeelf. 3 Cromell was oimilarly approached. 4 Neverthelese he played no part in the negotiations which followed. Neither Capon, for Ipowich, nor Treshem and Higdon, for Oxford, mentioned him in their roports to Folsey. 5 They wont to Gardiner, who appears to have done hio best to prevent the threatened dissolution, 6 but they did not go to Crommell whose connection with the colleges had boen

1. V.C.H. Bucks., ii.113,3631.

2. $\mathrm{Li}_{\mathrm{i}} \mathrm{P}_{\mathrm{l}} \mathrm{iv} \cdot 6222$.

k. Ibia. 6524. 6. Ibid. 6523,6579,6679. with the ro-founding of the colloge,
early as 1 August 1530 (ibid. 6545 )!

3. Ibid. $6529,6574-8$.

8. Ibid. $6377,6579,6666 ; 6510,6523$. He seems to havo had a good deal to do knoring about it as 
oo much closer and by no moano yot at an ond. The mon apponled to - Norfolk, Gardiner, Nore, Fitzwilliam - all held official and influential pooitlons; Cromoll, we mat conclude, had no ouch position at this timo (1530), and his work on bohalf of the colleger was not rork in the king's gervice. ${ }^{1}$

Thile thus occupied with matters arioing from the oclipso of Toloey, Cromeli did not negleot his orn private business. Ho continued hio legal practico: a cortain Richard Reynoldo appeare geveral times in the correspondonce, both in connection vith a legal arbitration undertaken by Crowrell botreon him and another merchant, 2 and with a request that Cromwoll intorcede for him with the king. 3 Arbitration in logal ouits oeoms to have been a not uncommon employment of Cromelil's at this time, and drafto of avards and agreemento to abide by his decioion ourvive anong bis papers.4 A parson threatened with prae= munire sought his advice; he represented a man sued for debt by the king's officers; a man who had boen told to submit a petition to the council retained his services for the draftine

1. Strype (Eccl.jlem., I.j.181) atates that tho continuing of the 0xford college vas due to the efforta of both Gardiner and Cromill, but be adduces no proof beyond the lact that they rero both appoalod to by Holooy.

2. L.P. i $5948,6005,6133,6137$.

3. Ibid. 6064. In this lotter, writton on 29 Novombor 1529, Reynolde oddly enough declared that he had no-one to intercede for hin except Wolsey and Cromrell.

4. Ibid. 6102,6126 . 
of tho "inotmmont". 1 lior did Cromroll'o privato trading ceaso in this year mhon ho firat ombarkod on a fully political careor. His friond, Stophon Vaughan, was ontrustod with somo sporwaceti to soll for him in Flanders, 2 a taok that was not dono by the timo Vaughan returnod to England in 1532. Some light is throm on Cromrrell's businesa.methode by a romark of Vaughan's that the opermaceti noro "very oubtly packod", boing nothing like as good on tho inside as on tho outgide. 3 For a eriend Cromell acted as intermodiary in a horsedeal.4 He recoired many appoalo for asgiotance, and it is noticeable that in 1530 ouch letters did not request official patronage but woro addressod to the man who was Wolooy'a right hand or woro quite private in nature. 5 Wo way 800 in this one more proos for the fact that so far Crompoll did not occupy a sufficiontly public place to justify any asoumption that he had yet any influonce on policy.

But Cromrell sat in the Refomation parliament, and traces ourvive of his activitios thero in its first sesolon. They aro all evidence of his pork and atanding as a private

1. Ibid. 6058; I.P. Add.576,666. There is nothing in thio last letter (dated by the oditor "Noromber 1529") to auggest any personal connection between Cromell and the council.

2. L,P. iv. 6744, and in many other letters from Vaughan.

3. B.L. Galba B.I, 1.4 (L.P. ..808).

4. L.P. iv. 6800 .

5. Ibid. 6116-8,6139,6682,6783; I.P. Add.691. 
member and do not shor him as a royal oervant in the houso. Ho was a laryor, and as such wao no doubt included among tho lamyers whom the cormons appointed to draft the bille concorning probato of vills, mortuarioo, and pluralitiog; ${ }^{1}$ Hall ouggeste that all the lawyers in the house nore thuo appointed, and Cromell, who had taken a prominent part in tho parliament of 1523, was oomothing of an old parliamontary hand. ${ }^{2}$ Te also have a draft bill concerning "protoctiong" which is endorsed "for protec ciono Lastor Cromell, Laster PoI Withepoll, Waster Halle of Greyes Ynn, Lastor Soye, Haster Branyag". 3 all these men oxcept seyo aro knomn for certain to bavo aat in this parliamont, 4 and thoy wore undoubtodly the comiltoe to whom the bill ras entruated for conaideration and dralting. The matter mith which it attempted to deal abuses of the king's protection - was one on which Cromell, himsolf a lawyer and a merchant, may have beon something of an authority; at any rate, he prosided over the combitteo Which included a leading London merchant (Withepoll) and the latryer and chronicler Hall.

Cromrell was concerned with another bill in parliament. It can be shom that parliament attempted in this session to

1. Hall, Chronicle, p.766. 2. Merriman, i.2711.

3. P.R.0 SP 1/236, 1.166 (L.P. Add.063). The endorsement has been largely destroyed olnce the document mas calendared, but such traces as remain confira lir. Brodie's reading.

4. Official Returng, i.36811. 
prosent a petition which wao worked up, two yoaro lator, into the "Supplication againgt the Ordinarieg". Of the four surviving drafts of this Supplication threo nero dram up bofore the parage of tho acta concorning probate and mortuary, that io they wore dram up on the 1529 sesgion, and it was these that Cromrell correctod. ${ }^{1}$ If the Supplication ras imposed on the commons by the king, Cromelli's revialon of it would shor him to have been in the royal service as oarly as Norember 1529; but if tho document really originated in the commons, then it rould oeom that Cromroll was entruated by the house with its drafting. The fact that nothing came of it for the time being ouggests that the king had no hand in it, a conclueion otrengthened by the fact that grierancea againat the clergy rere genuinely entertained by the commong and did not have to be fostered by the government. ${ }^{2}$ Horeover, the first draft of ali looks most convincingly like a document emanating from the comons. 3 Crombell's corrections must, therefore, also be considered as part of his parliamentary activities rather than as aigns of rojal service. All this

1. The drafts are L.P. $\nabla .1016(2-4)$ and L.P. IV.6043(7), which lattor was completely misunderatood by tho ditoro. They have been investigated in the original, but as a fult discussion is impossible in this place it villnhecessary to confine ouroelves to stating the conclusions arrived at.

2. C1., 0.G., A. I.POllard, Factors in Modorn Hiatory, pp.11411. The importance of the true nature of the "Supplication", as a measure of the attitude of parliament and nation, is clear but cannot be gone into any further here. 3. L.P. $\nabla .1016(3)$. 
goog to shom that Cromell achioved a certain pooition of importance in parliament, as he told Cavendish ho would, 1 but not that ho was as yot in the king'o service.

Iention mat not be made of the slender evidonce of such service in 1530. There survives the draft of a council letter, dated 31 May (1530), requesting the oonding up to London of two criminale who had taken roluge in the liberty of Ripon. ${ }^{2}$ It io unsigned, but the calendar hoads it "[Cromwell] to [the Toim of Ripon]". It is not, horrover, in Crommoll's handrriting, or in that of any knom clerk of his, and it is difficult to 800 on what the oditor basod his assurption that cromrell wroto or dictated the letter which ras, in any case, writton on the behalf of a number of men, "vo of the counsol1". In August 1530 Cromrell's handmriting appeared on two drafts to be signed by two messengers of the King's Receipt, acknorlodging the receipt of various combsions, indentures, and the like, from the attomey-general. 3 This was the roris of a subordinate civil servant. Lastly wo may mention a petition from the city of Briatol to the king, dated late into 1530, on which there appear a fow corrections in Cromell's hand.4 This might suggest that he handled such

1. Carendigh, Wolgey, p.180.

2. P.R.0. SP 17286, 1.307 (L.P. Add.687).

3. P.R.o. SP $1 / 58$, 1f.19-22 (L.P. iv.6598).

4. L.P. Add.705. An inapection of the original hag failed to reverl eny significance in the corrections. 
petitiono before they reached tho king, offoring advice on details of phrasing, or oven thet he received potitions for the king, but it is much more likely that he ras only approached by the potitionero 8.8 a person suitablo for that sort of thing, and that the document in fact bolonged to his private legal practice which included the draming up of petitions to the council. 1 Thus the picturo which wo must have of Cromell in the first year after Folsey's fall is composed largely of rork for Holoey, for himgelf, and in parliament, with the first laint beginninga of a career in the royal service. ${ }^{2}$

The picture changes with quite dramatic suddenness at the beginning of 1531. To this extant re may credit tho stories of Chapuys and Polo: thero certainly seoms to have

1. E.g., ibid. 666 .

2. Te have not included in the exidence for Crommell's activitios a letter from Richard strote to $\mathrm{Dr}$. Leo, requesting him to soo Cromell about the succeseion to the Staffordshire priory of Calvich (P.R.O. SP 1/37, 1f.60-1). This lotter io calendarod under 6 April 1530 (L, P. iv.6313). To believe it to belong to 1531, for these reasone: (1) The anstrer to Streto's lotter is L.P. $\nabla .277$, written in May 1531, not 1530. (2) The letter is addressed to Dr. Lee, chaplain to the king. Brerer's inder makes it plain that he thought this to mean Edrard Loe; ro ouggest it meant Rorland whom ro meot as Crontrell's agent in monastic affairs in 1532-3, and tho ras not chaplain to the king until 1531 (D.N.B., xi.815a). (3) Calwich ras suppressed by agreement with the founder's heir on 27 April 1532 (L.P. V.696). This heir is roported to be claiming rights of presentation in L.P. "1F.6313; it seers unreasonable to suppose that the suppression, agreed on clearly becauso of the vacancy, should have come trro full years aftor the last prior's death. 
boon a point at which Crompoll became a man of gomo importanco about the court, and the chanjo oeome to have boen exproosed in hir apjointmont as councillor. This modo of addroos ras lirot uood in a lottor dated 10 Jenuery 1531,1 cre it recamo normal after that. But the exact degroo of importanco, tho ectual influenco axercised on policy, can again only bo ostablishod by acruting of Cromtroll'g corroapondonce and an analysis of his rork.

Foloey was dead, and there was no sore rork to be dono on hie bohalf. The collegeo continued to trouble cromoll, but not 80 Irequently 80 bolore. His pleasure mas rocuostod when the king rroto to what was nor to bo called King'g Collogo, 0xford, for the next aroldance of the place of beadle at law; he continued to supervise the college accounte and financer; poople farming the college lands bothored hit Fith their affeirs; Fhon the dean died tho canons rould do nothing without consulting him. ${ }^{2}$ Ho was one of the trustees at the re-founding of the college.3 Although it wis not until 1532 that he ras officially appointed tho king'a roceivor-general and ouperviser of the lando lately belonging to the colloges, 4 he looked nfter the collection of rente from these lands all through 1531.5 But this business ras

1. L.P. $\nabla .38$.

2. Ip1d. 196, 334, 341, 228, 899, 1632, 1647 .

3. Rymer, Foodere, $x i v .443$.

4. L.P. V.701.

5. Ibid. $83,174-5,273,842$. 
no longer in the Loroground, and it come to occupy lese and 1008 of hio attontion.

Private affairs continuo to play thoir part in tho correspondonco. Cromoll bought and ronted lands and housos in thooo yoars and bogan his building activitios in London, 1 he did not allow his privato legal practico to drop altogether, ${ }^{2}$ hos buginoso enterprisos in Fianders woro not yot at an ond, 3 thoro rore still \& good many privato lottero mixed up with tho moro official corrospondence. 4 Eut whilo an occasional lettor of appeal for help or patronage atill doos not suggest any official porers in the person appoaled to, 5 the largo majority - and they are a vory large number roquest things which only a man in farour and porror at tho court could bo expocted to procure. 6 Cromell's growing importance ia iliustrated by the fact that people sooking his favours included now such ren as the earl of luntingdon, Sir Nicholad Carom (mastor of tho king'a horgo), Sir John Gage (vice-chawberlain of the hougehold), Christopher Haleg (attornoy-genoral), the earl of Essex, and the duke of Suffolk.7

1. Ibid. $671,679,963,1028,1065(33), 1562,1192,1339,1435,1442$, $1454,1404,1573,1723$

2. Ibid. $142,172,386,440-2,499,541,620,672,1161$.

3. Ibid. 311,808.

4. A for references vill suffice: ibid. 15-22, 212, 479, 496, 591.

5. Ibid. $279,338,359,481,644,840$.

6. Such letters occur constantly from 1531 ontards; there are sowothing liko 200 in L.P. $\nabla(1531-2)$ alone.

7. L, . . $\nabla .323,429,538,620,945,1403$. 
Tho bulk of Cromell'o corrospondonce now concernod royal and official buoinero. Tho corporation of saliabury appoalod for a gaol delivery which they thought long ovordue; ${ }^{1}$ Crommell recoivod advance information on logal suitors coming to appeal to him; ${ }^{2}$ ho ros joinod with the king'a legal officera in exocuting, tho king'o legal business; ${ }^{3}$ alone or vith othoro he heard and adjudged legal appealo; ${ }^{4}$ prisoners and felons were brought to his notice and disposed of at hio pleasure. 5 It was as one engaged on legal business for the king that ho nor began to be the king's agent for parliament and legiolation. 6 Even whon he was with the king at Calaio in septembor and 0ctober 1532 he reg consulted by people at home on

1. Ibid. 182. 2. Ibid. $23,298,360$. 3. Ibid. $627(18)$.

4. Ibid. 507,668-70,759,793,1057,1298.

5. Ibid. 830,1092,1139(18),1120; L.P. Add.7\%1.

6. CI. L.P. V.394 for instructions to Cromoli on such matters. A cese hes been made out for supposing that he ras engaged 8e early es the beginning of 1531 on the revision of treason billo to bepubmitted to parilament (I.D.Thorniej, "The Troason Logiglation of Henry VIII," Trans.R.Higt.30ce, 1917, pp.87f1.). Liso Thornley based her case on hor claim that the corrections on all five extent irafts of the treason act are in Crompell's hand, and she quotes the support of Ir. Brodie for her assumption. It is, homover, quite cortain that on only trio of the drafto the correctiong are in Cromrell'g hand, nearly ell the remainder being in that of lord chancellor Audeley. Thero is oomo superficial resemblanco betreen their handritings, but the difference is really quite cloar. Cromroll's writing is more rogular and inclinea alightly to the right, and is invariably easily road, whereas Audeley'g is usualiy upright and woro of a ocraml. Audeley also used a number of orthographical peculiarities which nevor occur in Cromwell's mriting ( $\theta_{0} g .$, the plural onding in $-z$ and the use of "yt" for "that"), and employs a small c rhich is quite differont from cromwell's. There are othor smaller differences. Tho only drafts of tho treason act corrected 
logal mattera. 1

In sddition, he began to be active about the royal revenues and poscesaions. He io frequently found rocoiving grants of land to the king's uso, 2 and he ras, for inotance, the king's agent in the exchange of lando by which Honry acquired the manor of Piohow from lord Scrope for Anne Boloyn.3 He supervised the king'o rorks at Heotminater and the Torer of London. 4 Then Sir John Rugsell ranted repaire done at the manor of the Lore Henry refuged to do anything without soeing Cromell firot.5 The firet aign of Cromell handling the king's money is an ontry of $\$ 13.6 .8$ which ho recolved for the building of the king's tomb on 31 Decerber 1530.6 In 1531 he is found supervising the colloction of rovenues from the vacant oees of Coventry and Lichlield, and of the clerical subsidy." However, his full activities as a financial minister did not begin until hio appointment ao waster of the king's jerrele on 14 April $1532 .^{8}$

- by Cromtrell rere thoso called by Liss Thornley A2 and $A 3$, i.e. the tro drafto propared for the oession of 1532 in accordance with the instructions received in L, P. $\nabla .394$. 1. L.P. $\nabla .1444,1446,1450,1476$.

2. Ibid. $285,409,814,1136,1309,1445,1470,1537,1571,1580-1$, $1607,1611,1684$.

3. Ibld. 915-6,1015,1445. C1. statute 25 Henry VIII c.31.

4. L.F. V.260,1086,1467, 1487, 1719,1781.

5. Ibid. 976 .

6. Sir Harria llicolas, Privy Purse Expenses, p.101.

7. L.P. $\nabla .27 \%, 332,848-9,1675$.

8. Ivid. $978(13)$. 
All these activities show that Cromwoll ras ontruated with a growing amount of legal and financial business, but such rork 18, after all, the fiold of an executivo agont, of an administrator, and does not imply any connection with tho sheping of policy. So far, nothing has boen found to justify Lerriman'o asoumption that bofore 1533 Cromell Was alroady the moving opirit behind Honry'a anti-papal policy. On the contrary, ono thing has emerged cloarly onough. Crompli'g rork shows him to have gradually rioon in the king's estimation and to have gradually attracted to himself wore and wore of the adwinietrative detail of government. He built up a position of porrer and influence by degrees and did not achiere it at one bound. Nor did he gain this position by presenting sore plan of policy but by cloge attention to tho routine rork of adminiotration.

In October 1532 he accompanied the king on hile expedition to Calais and Boulogne, and the rork he did in connection with that enterprise shows where he otood at tho time when hio apprenticeship was drawing to $\dot{a}$ close. In the main, he ras employed on detailo of preparation and finance. 1 It is also clear that he was otill rorking his way up, for it was thought worthy of remark that ho had managed to acquire golden opinions

1. Ibid. $1237,1239,1297,1298-9,1392,1600$. 
with both kings. 1 He remained close to the king, but even while ho was out of England he was careful to keop in touch vith affaire there.2 In January 1532 he could deprecate bis own importance in a letter to Gardiner, reporting Henry as saying that Gardiner's absence was "the lacke of my right hand, for I am nor so mocho pestrod with busynes and haue nobodie to rydde ne depeche the same".3 But in Auguet that year Gardiner wrote to hiw: "I sende vnto youe berwith... the treaty with Iraunce and a commiseion signed rody to be sealed to the dolng wherof ye must necessaryly helpe or it ohal I feare me be rndoon." 4 It eeeme that during this yoar 1532 the king's right hand was changing identity, though there is no reason to suppose that Henry ras not master of his brain and originator of his own policy. It is in connection with the French treaty and the Boulogne meeting that we get a glimpse of Cromell acting in a more than purely executive capacity when a draft letter on the "king's groat matter" was sent to him for correction with a vier to leaving out things too secret to be commicated to the French. 5 Howerer, thio piece of evidence comes late in the period under revier, and

1. P.R.Q. SP 1/72, 11.11-12 (L.P. V.1509), Alvard to Cromrell: "Alao I am veray glad to here the good Reaporte howe the Kyngea grace hath you in so great favour, And the frrencho King also."

2. L.P. V. $1457-8,1467,1472,1513$.

3. Ibid. 723 (Lerriman, i.344).

4. P.R.0. SP $1 / 70,11.230-1$ (L.P. V.1245).

5. L.P. $\nabla .1305$, lettor of 9 september 1532. 
in general the case is clear enough. Cromell roge gradually in the royal oorvice and ras an agent rather than an originator of policy until about the middie of 1532.

Fo must yot doal with tho negotiationo which Stophon Vaughan, Cromell's friond, carriod on rith Villiam Tyndale in Flandero in 1531, negotiationo of which Werriman aade a good doal. 1 It was his vier that Cromoll neoded an "intelligent and consiotent ally to help hirs carry out his schemes of 'political Protostantism'", and hopod to find his in Tyndale whose "Obedience of a Christian ilan" advocated the policy of subjecting tho church to the king which Werriman held was poculiarly Cromell's. Henry had denounced Tyndalo's books, in particular his translation of tho bible, in the atar charsber on 25 say 1530,2 and at firot sight it rould indeed seem, in Merriman's mords, that "the lact that cromell was able to persuade the king to permit him to attompt" the enliatment of Tyndale "io a good proof of his influence with Henry". Yet it is certain that what me have so far seen of Cromell's activitios and position early in 1531 makes it diffiealt to boliero that ho hed any such influence. The story of the negotiations is simple. On 26 January 1531 Vaughan wrote from Bergen-op-zoom that in accordance Fith instructions, perhaps received boforo he left England at 
the ond of Horomber 1530,1 he was trying to get in touch with Tyndele. On 25 larch he hed a copy of Tyndalo'o "Anerier" to Hore tho printing of which he was hoping to hold up, and on 18 April and 20 lay he reported converoations with Tyndalo which soemed to indicate that the reformor wight at last begin to truat Henry's promises.2 But somo timo in May Cromroll wrote a violent lottor to Vaughan, describing Henry'o anger at Tyndalo'g lateot book and ordoring an immodiate ond to the negotiations.3 Despite this comand Vaughan once more recurred to the businose, ${ }^{4}$ but any chance of bringing Tyndalo back to England ras obriously gone.

The question of who was the prime mover in the affair can be answered if it can be establighed what advantage was expected from having Tyndele in England, and hor and why tho business foll through. Vaughan usually roported to the king, but occasionally aloo to Cromsoll whose friend and servant he was. He pas not at the time in the king's service, and the original reason for his living in Flandero was that he had buginess there as a merchant adventurer. The fact that he Fas used might therefore suggest that the idea of enlisting Tyndale originated with Cromell who may have pointed out to Henry that he had a good man on the spot, a man moreover with

1. J.F.Llozley, Jilliam Tyndale, p.187.

2. L.P. $\nabla .65,153,201,246$.

3. Ibid. 248.

4. Ibid. 303. 
decidedly reformiot leanings. 1 on the other hand, the idoa of employing pampleteors, of finding men able to oupport "the king'o great mattor" by word and pen, was older than the Tyndale affair. The opoed with which Cranmer's suggostion of asking the univeraitios for their opinions ras adoptod by Henry ohors hor readily his aind embraced such methode of varfare, and thio otrategy of collecting and publishing opinions ras still going on while Vaughan ras trying to win Tyndale. The addition of another friter to the toam who nore propagating Henry'g point of vier rould not have marked a ner departure in policy.

The king himelf dirocted the nogotiations. Vaughan ras comigsioned to obthin "the knorlago of such thinges as your magostie comaunded me to lerne and practise in these partieg, and therol taduertioe youe", 2 he received his inotructiono "from my Laister maister Crumell, at the comaundement of your magostio", 3 and though Cramell was his usual channel to the king he was not the only one.4 No-one wanted Tyndale's help becauge he was a relormer. The argument which Cromsell put formard in the king's name was that "if it were possible by good and holsome oxhortacions to reconsile and

1. C1. ibia. 574 for Vaughan's religious vierr.

2. B.H. Galba B.X, 1.46 (L.P. $\nabla .65$ ).

3. P.R.0. SP $1 / 65,1.271$ (L.P. V.246).

4. B.L. Galba B.X, 1.47 (L.P. $\nabla .65$ ): "Theras I lately apperceyrod by certeyn lettores directed to me frow Maister ffitzmiliam, trelsourer] of your householde...". 
conuert the oaido Tyndele from the trayno and affection thicho he is nowe in, and oo to excerpto and tooke anayo tho opynyono and Lantasios oorely rooted in hym, I doubt not but the Kyngoo highnos trolde bo much loyous of his conuoroion and amondomont. And $s 0$ being conuerted, if he thon wolde return into this Realmo, vndoubtedly tho Kyages royell magestio is so inclyned to mercie, pitie, and compassion that ho refuseth none whiche he seythe to oubmyt thom self to the obedyonce and good order of tho world". 1 Tyndale rould firot have to recant. Tho reason why he oteadfastly refused Vaughan's overtureo was that he kner too much of the persecution of horotica thon going on in England, 2 and whon Vaughan was told to turn hio attention to Frith it ras made plain that an abjuration of Lutheran vioms was the first condition of the king'o mercy. 3 There were no "ochemes of political Protostantism" behind the negotiationo.

The king torminatod the business when it became clear that no help for the divorce nas likely to come from Tymale Tho had just condemnod it in his "Practico of Prelateg". This book, though published bofore Vaughan left England, probably did not roach Henry until some time later.4 Tho book againot lore clinched the matter; thio 780 no possible

1. P.R.0. SP $1 / 65,1.271$ (L.P. $\nabla .246)$.

2. L.P. $\nabla .65,201$ 3. Nerriman, 1.338.

4. J.F.Mozloy, Villiam Tyndalo, pp.16311.; R.Domaur, Tyndalo, pp.2321. 
meok adrocato of the royal views. 1 Honry peraonally controlled the negotiations milo they wont on and personally decreod their ond, and Cromoll was but an agont of the royal vill, though an agent on a rathor largor acalo and in a moro important matter than any we have so Lar geon him connected with. It becomes reasonable to ouppose that Cromoll was the moving spirit in tho affair only if ho is asgumed to have alroady achioved a position of influence, but such an argument mores in circles. Cromwell was otill working his way up, and his lear that a faloo step might min a pooition as yot very precarious best explaing the almost hysterical tone in which he commicated to Vaughan tho king's orders to drop the matter.

Thus, notil thstanding the presence around the king of ouch great won as the duse of Norfolk, Gardiner, and the Boleyns, Henry hed no chiel minister betreen Tolooy'o fall and about the middle of 1532. By then he had found and teoted another man who could be trusted with the multifarious details of domestic adminiotration and with the delicate manipulation of a diplomacy which relied on keoping in with both France and the emperor, and who hed moreover an original mind and a policy of his orn which Henry found to his liking. The revolution which began on 3 November 1529 with the meeting

1. Jerriman, i.33511. 
of the Roformation parliamont may have beon Cromollian from the otart in that tho things done agrood with what we knors of Cromerti's political viera, but they agreod equally woll with tho imperious will of the king. Furtherworo - though this rould take us too far into a fiold which ro havo purposely excluded from the prosent study - a good caso can be made out from the statute book for the view that Cromreli's arrival to power at the ond of 1532 resultod in a nor forcefulneso and a ridor stroop in the measuros taken to broak with Rome and subject the church to the crom which go far to prove that his influence on policy mast be rated very $10 \pi$ until that time. Tho evidence of his correspondence has shom a gradual increase in the amount of buginess handled by him, a gradual sproading of his influence over difforent opheres of the king's affairs, a gradual accurulation of duties and responsibilities on his shoulders. There were definite otages in his rise to porer under the king, points at which his position appars crystallieed for a monent and from which the uprard path assumed a different aspect. These otages, which are simply significant points reached by Cromwoll in the administrative organisation, wast nor be ascertained and as far as io possible dated. 
II. The Staged of hio Riso.

In October 1529 Cromoll's position was very soriouo. It seomed inovitable that the cardinal's fall should also involve his servant and agent, his "asaecla" as Pole called him. ${ }^{1}$ He himgelf appeared for a momont to have given ray to despair, though the mood did not last and was soon replaced by more characteristic leatures, purpose and energy. ${ }^{2}$ If Pole can be believed, people rere clamouring for his head and the rumour rent round London that he had been sent to the Torrer and was to be executed. 3 Vaughan, in Flanders, was very worried: "I...am greatly in doubt bov youe ar introated in this sadyn ouerthrow of my lorde, your master. I neuer longed so soro to here Irom youe as notr." 4 He asoured Cromwell, of any service it was in his porrer to render and advised hir "to praye to god to lende youe a constant and paciont mynde, not doubtyng that yo shall...escape without any daungier." This was on 30 0ctober 1529; throe months later, on 3 Fobruary 1530, he wrote again, in answer apparently to Cromell's reply to the letter just quoted: "I... was therby asserteyned all thingeo to haue succeded euyn as I desired. Youe now saile in a sure haryn." 5

1. Polo, Apologia, p.121.

2. Carendiah, Wolsey, pp.16911.

3. Pole, loc.cit.

4. P.R.0. SP 1/55, I.246 (L. P. i .6063).

5. P.R.0. SP 1/56, 1.252 ( L.P. iv.6126). 
That oteps had Cromirall taken so to altor his pooition? Ho left Eahor on 1 Hovomber 1520, doterminod - in hid favourito phraso - to make or mar, and promising Cavondish that ho would shortly hoar from him again. He roturnod two or throo dayo lator, and whon bo cans to Eshor "with a pleasaunt countenance" he told Carondhsh that he "had once adventured to put 1ni his sooto, where ho rould be better regarded, or over tho parliamont rere Iiniohed". 1 He had ontorod parliament, and the manner of his entry is of conoiderablo importance to uo es it helpe to oxplain his "plessaunt countenence" and air of hopefulneso.

Carondioh aseerte thet Cromold changed places at tho leot mowent with the son of Thomas Rush who had been olected ag a burgeso to the Reformation parliarent.2 Fantastic though this soundo, there io at loast one knorm case of such an exchange boing effected. 3 Cavendioh adds a good deal of circumstantial detail, claining that he 8 am Cromell ride off from Esher in the evening of 1 jovember togethor vith Ralph Sadler, his clerk; yot ho ras miataken. 4 At four o'clock on that very day sadier wrote a lotter from London which cannot posiibly havo boen meant for anybody but cromell. 5

1. Cavendish, Volsoy, pp.177,180. 2. Ibid.179. 3. Cf. A.F.Poliard, "A Changeling L.P.," Eull." x.201f. 4. Ceriendish, Trolsey, 177.

5. B.L. Cleop.E.iv, 2.178 (E,p. iv,App.238). The loat rith the address is missing. The letter ig printed in full by verriman (i.67l.), with one small but important miotake. 
Ho had boon to tho court and had spokon to sir John Gago, tho vice-chamborlain, "and according to your commundemont novod him to speke vnto my lorde of Norffolk for the burge日es Romme of the parlyament on your behalf... Wherevppon my saido lordo of Norffolk answerod the salde Magtor Gage that ho had opoken with the king his highnes and that his highnes was voray roll contented ye ohould be a Burge日, So that ye wolde order yourself in the seide formo according to suche instructions as the saide Duke of Norflolk shall gyuo you from the king". Cromell was to come to London to discuse mattero with the duke, and possibly with the king himoolf; Sadler's language is not quite clear on that point. "As touching liaster Rusoho ...I will speke vith him this night, god milling, and know rhether ye shalbe Burges of Orforde ${ }^{1}$ or not. And if you be not olect there I will then, according to your ferther comwaundenent, repayre vnto lieoter paulet and roquiere him to name you to be one of the Burgeses of ono of my lordes tormes of his busghopriche of Fynchester."

There aro hero two distinct pointo. Tho king'o approval was sought for Cromoll'o entry into parliamont, but hoither

1. This is the corroct reading, as the original proves boyond a doubt (cl. aloo A. F.Pollard in Bull., $x_{.24}$ ). Both L.P. and Lerriman wisread "Oxford". Orford aloo makes senso Where oxford does not; Rush had no connection with the latter, but he (a Suffolk man) was atyled burgess of orford

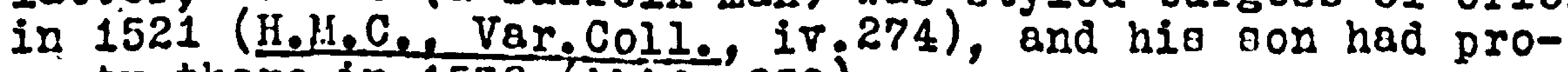
perty there in 1538 (ibid. 259 ). 
the king nor lorfolk had anything to do with the actual provielon of a seat. There ras no question of official patronage. Both the mon appealod to wero old friende of Cromoll'o; Rush had boon agsociated with him tho the ogtablishment of Folooy'd college at Iperich, 1 and Paulet had been a oervant of Molegy's beforo he entored the royal service as master of the rarde and was otill active on Woleey'a behalf in June 1530.2 Although orford, in Suffolk, may be regarded as falling within the Quke of Norfolk's genoral sphere of influence, there is no evidence of any direct connection betreen duke and borough until 1532 when Norfolk was granted some land there which had once belonged to the priory of Snape at Aldeborough. 3 Ag for the alternative, eome borough belonging to the bishop of minchester, the king wight be thought to heve held all such boroughs when it is remembered that Holsey had ourrendered all nie poseeseions to the crom. 4 But an inquidition hold after 14 July 1530 declared Folsey to be otill bishop of Fincheoter and solzed of certain manors, 5 oren though the biohopric was not included in the restoration of some of his possessions and be only drep \& pension from it in 1530. Te must also note a clear distinction betreon the tro possibilities in the rording

1. L.P. iv. 1024(vi),459ع. C1. also ibid.6110.

2. Ibid. 6436,6438 .

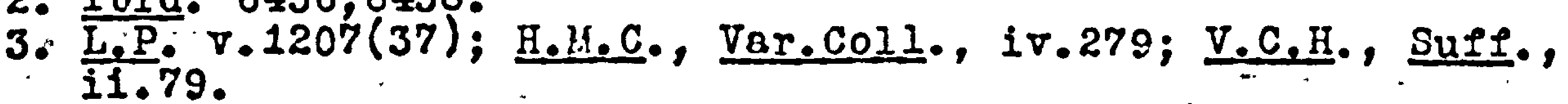

4. L.P. iv.6017.

5. Ibja. $6516(13)$. 
of Sador'o lottor. Ao far as orford is concorned he will find out whother thero is a chanco or not, and failing orford ho vill require peulet to provide Cromell with o seat, and although "renuiore" way bo no more than "esk" it yot is plain that there ras no ouch doubt about the second alternative as about tho firat. It io probablo that Cromoll hoped to enter parliament without using hio connection with Wolsoy, and that Sadier was therefore instructed to try the lese certain ray lirst. The mention of Rush incidentally helpo to explain the origin of Catendioh's story; be presurably beard a garbled version of the truth in which the name occurred, and he drer his orn conclusions. The most important point about the letter is that sadier had received his ordors belore the king's approval had been obtained. This makes it certain that no help ras expectod from the king in the finding of a seat.

In the end Cromell sat for Taunton. ${ }^{1}$ Considering only the diocesan boundaries, Professor Pollard came to the conclusion that reither of Cromell's approaches aucceeded, thus leaving it open how he managed to secure that partleular seat. ${ }^{2}$ Later, horever, he seens to have seen the significance of the constituency, though he did not work the matter out completely. ${ }^{3}$

1. Official Returng, 1.370. 2. A.F.Pollard, Ienry VIII, pp.2541.; Fact, in Mod.Higt., p.120. 
Taunton was, as a matter of fact, one of the oldost and most ralusble possersions of the ses of Vinchester. There exist Saxon charters which clain that it was given to Finchoster as early as 721, and as lato as the serenteonth contury it produced about a third of the seo's enormous incomo. ${ }^{1} \mathrm{As}$ lorde of the manor the blohops appointed the bailiff for town and borough who made the return of elected membera, as the earliest extant, frow the reign of llary, shor. ${ }^{2}$ Winchester influenco vas thus oupreme at Taunton, and Cromell actuelly sat for the pick of the Ninchoster borougho. Though Rash: could do nothing for him, Paulet responded nobly. lior nood it ourprise us that cromell could be slipped in at so late a stage, on the day before parliament met. It was not unusual for a return to be made after the opening of parliament, and Taunton itself ras not in time for the oheriff'e return in 1543.3 One may rell leuppose a similar vacancy in the retury for 1529, Taunt on poselbly having left the appointment of at least one of its members to Paulet who appears to have had a personal connection with the tom. 4 Cromrell, then did not rely on the king or llorfolk to get him into parliament, but he sought their approval, or rather, he sought the king's and used llorfolk to obtain it.

1. R.G.Hedworth thitty, History of Taunton, pp.1,182,287. 2. J. Toulmin, Hiotory of Teunton, pp.3071.

3. Cf. A.F.Polilard, in Bull., x.24.

4. L.P. i .5407 . 
Merriman thought that he tried to win tho favour of the now winister, that ho ront "straight orer to hio [Wology'g] bitterost enery".1 This sooms a misreading of the situation. The Lavour which Cromoll was after was higher and more important then any the duko of Norfolk could bostor. It rao not the duke rhom Cromell wiohod to servo, but the king. His main ambition in entering parliament was to prove hio usefulnose to Henry and win his approbation. No doubt, there wero bther reasono why ho should wioh to take part in the important businese which everybody could soo rould be dealt with in the parliament which mot in 1529,2 and Cromoll who had sat in 1523 may havo acquired a liking for, and somo efficiency in, the rork of a member. But his chief roason for wiohing to sit in parliament was aurely that thero ho rould be able to live domn tho associations of the past and pould have a chance of building a now careor. As he had told Carendigh, he rished to be "better regarded". Entering perliament was something in itoolf; entering it with tho king's approval was ovorything.

Crombll's entry into parliament now appearo to us as the first definite step in his rise to power. It was the point at which the ner allegiance bocame possible, though the old

1. Lerriman, i.681.

2. The French ambassedor, e.g., foreser, that the priesta rould have "terrible alarms" in thte parliament (L.P. iv.6019). 
ras not apparently throm array. 1 It markad tho tranoition from dangor to sefoty and 700 clearly the otarting point of nis careor. He had soomod sot on tho road to fortuno ao Molooy'o right-hand wan, but tho cardinal's lall provod this to have beon a falso otart and Cromroll now began again.

Hio noxt otep was to enter tho royel service, that io to aay, to bocome tho king'o oorvant in the technical sense. It cannot be otrese日d too otrongly that such a titlo impliod $\dot{a}$ definite rocognised otatur. ${ }^{2}$ Tho mastor-gervant rolationohip governed much of the oocial and political life of the country, and it was bad for a man to bo masterlo80.3 Retainers no longer composed those large armod bodies of men

1. The story that Cromell was responsible for the deleat of Wolsey's attaindor in tho commons has beon told ofton onough (Cavendish, Holsey, p.180; Morriman, i.691.; A.Innoo, England under the Tudora, p.122). Prof.Pollard (Foloey, pp. 2611.) doubto its truth. But there ooomo no reason to think of it as wholly false, though it is fairly certain that ovon if Cromell took Tolsey's part he was not risking Henry's displeasure. It secms that the case was really sottled in the king'o bench and that tho parliamentary procoedings rosulted from the exceasive zeel of Frolsoy's opecial enemies (K.Pickthorn, Henry VIII, D.143). Henry was not among theso but llorfolk ras, 60 that Cromeli's dofonce of Holsey supplies one more reason for supposing that he sought the king'g favour rather than the duke's.

2. In enswer to lir. Pickthorn (Honry VIII, p.130) it must be gaid that king's servants ought to have meant to Edward Hell somothing more definite than either "capitaliots" hirelings" or "lir. Baldrin's followers", and that probably it did.

3. Cl. L.P. V.588, where Sir John Gage discusses the case of a can rhom he had dismiseod from his oervice rithout so far provising him vith a now master. 
who had fought thoir lordo' privato waro in the fiftoonth century, but ovory nobleman and wany a gontloman still had bio oervents who erequently wore livory and woro owarn to tho oervico of their mastor, ouch service now consisting more commonly bn kooping his accounto or collecting his rants, or in improving his social position by increasing his hougehold, than in deopatching his onomier. 1 In tho political ophoro a man's servants were his secrotariat: The caso of Wolooy, who built up a civil sorvice Irom within his own housohold, is woll known, and oven before his fall somo of his sorvants had changed masters and becomo tho king's gervants so that the training and knowledge acquired in the cardinal's gefairo Fere put at the disposal of tho otate. Henry realiood tho posoibilitios offerod by ouch on experiencod body of man, and as early a 1 Novembor 1529 sadier reported to Cromoll: "dyuers of ry lorde his seruauntes, as Haster Aluardo, Haster Sayntclerc, Laster Ifore日t, Humfrey liale, jaster iloros, \& other, ben elect and srorno the king hio seruauntes." 2 The

1. Apart from housohold sorvanto, retainers of the old type no longer oxioted. Charged at his fall with keoping thom, Crommoll claimed that ho had not transgressed becauso, although he had beon compelled by Iriends to increase his household by many rising young men, their parento "found thom", i.e. paid for their keop (I.P. XV.776). Thus whon a young man, a knight'o son, wished to onter Cromoll's oervice, hio father promised to Murniah him to do you cerVice like an honest man" (L.P. $x .206$ ).

2. B.L. ClOOD.E.IV, 1.211 (L.P. iv, App.238). 
phraso demonstrates clearly onough the formal, quasi-foudal, nature of the transaction. 1

The king's sorvants wore not necessarily about the court or engaged on the king's lmmediate business. Among the poople to whom the titlo was given we find the mayor and an ox-mayor of oxford who benelited from their otatus to the tune of fourponce a day.2 Thile their case illustrates one of tho adrantages to be derived from being the king's servant, a different and to us more important aspect is ahom in a lottor from sir Thomas Percy, brother of the earl of Northumberland, who in July 1535 declered to Crowell his deaire to become the king's servant because his brather was not treating his fairly; ${ }^{3}$ by ortering the king's service he hoped to get the king's protection and support. Cromoll, in 1530, had a similar reason Lor the same desire. II he ranted to get on he had to attach himself to some person of importance. He satr that on the occasion of his entering parliament he had decidod to go as high as posible, and he mast early have realised the importance of becoming the king's servant. That he achievod this and was properly strorn of the king's service is proved by a grant of January 1533 to Thowas Cromell, king's servant and councillor.4

1. It is true, horever, that in one case a man claimed to be Crompell's gervant by the simple lact of being receiver of certain lands which Crompell had acquired (L,P Xiv.II.298). 2. L.P. Xili.I.1342. 4. $\underline{L}$. $\forall j .105(13)$. 3. L.P. V111.1143(4). 
It io, horrover, difficult to ootablioh tho dato of thio stop. Thero exiats a lottor from Roynold Lytylprow of Norrich, datod 0 Fobruary and placod into 1531 by tho oditore of tho Lottorg and Paporg, in which ho told Cromoll that "I do here that yow bo the Kyngoo oarvand \& In hyo hoye faror". 1 The year of the letter was probably determined on tho basis of the only other sentence of importance it containg: "I do horo gayo that my Lorde Cardenall yo ded nycho I thynko yo not trewo." If this reforred to a truo report of Wolsoy's doath, Which took place in November 1530, it muat bo said that nerro sooms to have beon slow in travelling to Norfolk, for tro monthe after it happenod such an ovent ought to have boen knorn for certain. On tho othor hand, tho reforonce may have boen to a falso report, for it is quite possible that Holsoy's death ras being rumoured freely in the period after his disgrace, and woreover he pros very ill in January 1530.2 In that case re ought to dato Lytylprom'o lottor into Fobruary 1530. One thing, at any rate, this letter makeo cortain: Cromplell did not entor the king'o service beforo the prorogetion of parliament on 17 Docomber 1529,3 for Lytylprov, who sat for

1. Pa. R. SP 1/65, 1.132 (L.P. $\nabla .86$ ).

2. L.P. i . 6151 .

3. Parliament mas prorogued oeveral tiwoo from 17 Decomber 1529 to 16 January 1531 (cl., $\theta_{. g}$, B.R.O. DI 28/7, no.1, I.15). This deopito Pickthorn's otatement, quoting Buscho, that it was prorogued Irom 5 Decomber 1529 (Henry VIII, p.132) $\therefore$ 
Norwich, ${ }^{1}$ rould havo knom about ${ }_{\omega}$ and would not havo writton later aftor roturning howe as though it wore nerro.

Hall states that Cromell left Noloey and entored tho royal service about the time of Wolsey's journoy north, that is about April 1530.2 Opposod to this is Lytylprow's letter if it was writton in 1530, and aloo Vaughan's statement on 3 February 1530 that ho had heard that Cromell was to be included in Rochelord's embassy then about to leavo for Franco. 3 The report was mistaken but it could hardly have been made about a man not in the king's service. The king's ambassadors wero either king's servants or king's councillors, and we know for cortain that Crommoll was not as yot the latter. The most re can therofore say concerning tho exact date of Cromell's entry into the king's service is that it took place after 17 Decerber 1529 and before April-May 1530, and is likely to havo occurred early in 1530. Porhapa wo ohall not go far wrong if suspect that it came shortly after the end of the 1529 session and that it was a result of Cromwell's actitivites in parliament which he had entered with the king's approval and plodged to obey the king's instructions. The fact that he rorked so largely for Folsey in 1530 is no argument against this date. Quito apart from tho advantages

1. Official Returns, i.370.

2. Hall, Chronicle, p.769.

3. L.P. $i \nabla .6196$. 
in money and otanding which this work gave him, ho would havo undortaken it for any cliont and more particularly for hio old magtor.

Though he was not the king's sorvant he had a good way to go yot. A lettor Irom John Russell to Cromell, datod 1 June 1530, givor a pretty clear picture of Cromboli's position at the time.1 Tho king had asked Russoll ("knowyng the greate famylyaryte and aloo you my speciall firende") to ask Cromproll "that yt wold please you" to make out a patont for the lord chamberlain of the keoporship of Farnham caotlo which was in Wolsey's gift. "And also ho dosyryd you to sonde hym the fforwe of A Lettor how tho kyng ohuld wryte to my Lord Cardonall for his Conoent of tho same se for his aigne and seale, praying you that you wold send yt to my Lorde Chamberlayno as shortly as you can. And also that you wold sonde hym norde whother my Lorde Cardonall haue tho soalo of Fynchester or ellis the Chauncelor of Fyncheoter." Russell enclosed a Iriendly letter of his orm to be formarded to Holoey, and continuod: "After your doparture from the Kyng hio grace hadd vory good Compnycacion of you, whiche I shall aduertiso you at owr next metyng."

This letter shors Cromoll in the king's sorvice, drafting a letter patont for a royal grant, and it alo0 showa him as the

1. P.R.0. SP 1/57, 1.145 (L.P. iv.6420). 
link betroon court and cardinal. Both tho king and Rusooll rere uaing him as intermediary with Folooy. Tho polite and Iriendly tono of the lotter, convoying a royal roquest rathor than a comand, may be ascribod more to Rugsoll than to Henry, but it shows that Crowroll was by thon a man whom a courtier rould be well-advised and ready to address with courtosy. of greater importance is the little entence "After your departure frow the Kyng his grace hadd very good Compnycacion of you", which proves that Cromtrell had, on the one hand, ouch freodom of accese to the king that it caused no surpries to see them together, ${ }^{1}$ and on the other was otill much in need of being recomendod to Henry by other men. He was still trying to prove his worth.

On 27 Norember 1530 a correspondent wrote to tell him that "I am enformod that you ver in greto troblo for my Lorde cardynall causes and mattero, whiche right oore dyd grevo mo. Horbeit, sithen I haue had comportable tydynges that you be in lauour hilie with the Kynges grace, lordes, and comunyaltio ospell spirituall as temporall".2 Hall tells us that Crom-

1. C1. Holsey's words in August: "...and hauyng suche means of acceos to the Kynges preseno..." (State Papors, Henry VIII, i.371). Such statements increase one's doubts of the stories told by Chapuys, Pole, and Foxe all of whom imply that Cromrell jurped into prominence after his first intervier with the king.

2. P.R.O. SP $1 / 68$, P.65 (L.P. V.551). The letter is dated 1531 in L.P., with a note that it may be 1530. In 1531 Cromell's troubles on 7oleey's account rero over by two years which rould have made a relerence to them rather pointless. 
Foll was "nowly como to tho fauor of tho kyng" in January 1531. 1 There are indicatione, then, that torrarde the ond of 1530 Cromell took anothor otop formard by ontering tho royal favour ris well as the royal service, and indeed wo know already how thio stop was exprosed administratively. Crommeli becano a momber of tho council.

The nature of tho king's council at tho timo of Folsoy's fall is discussed in anothor place.2 Hore, a baro outlino rill have to cuffice. Professor Pollard has told us that though thero ras a large number of consiliarii in tho roign of Honry VII who wero "eimply retained to give logel or ghostly counsol" the king selected a smallor number "who roro appointed for life, sat with some regularity, were admitted on oath to an organised council, and vero paid tho regular courcillor'g Ioo", and that "Eenry VIII had clearly as large and varied an assortment of councillors as his father".3 The council of the oarly part of the roign was, we have boen sosured, not a dofinite body but "ouch toam of councillors as tho king ras then in tho habit of consulting".4 Recent discoreries seem to indicate that thero ras wore definition, 1080 royal caprice or accident of circumstance, about the

1. Eell, Chrontele, p. 775 .

2. Cf. belor, Chapter 5 , Section $I$.

3. A.F.Pollard, in E.H.R., exखvii (1922), pp.35611.

4. E.Pickthorn, Henry VIII, p.12. 
composition of tho council. 1 It now doema clabr that "thoro Tas a king'e council, not just king'g counool, that tho king's council functionod 80 an institution and. wao not just a 10000 body of royel adviserg". 2 All that can hore bo oaid with any certainty about the council at the tino of Cromplol'o ontry into it is that the council which transacted the normal day-to-doy business of the government did not normally includo Qll tho king's councillors and tended to be composed nore and wore of cortain of their numbor, either bocauge thoy hold high office of state or bocause the nature of their employmont for instance, an office in the royal household - necosoitated their close attendance on the king.

Cromell, then, became a councilior towarde the end of 1530. To have seen that though ho continued to be mainly occupied with minor administrative dutios tho vblure of official buainoss which ho transactod grer imonooly. To thio extent the accounts of Chapuys and Fore, and also of Polo if his intervieri atory can bo dated to tho ond of 1530, Fere right, and Cromitoll began to be of importance when he became a councilior, though thoy romenticised and drametioed tho manncr of his appointment. 3 An indication of hio place in

1. F.H.Dunhan Jr., "The Ellesmero Extracto from tho 'Acta Consilii' of King Henry VIII", E.H.R., lviil (1943), pp.30111.

2. Ibid., p.302.

3. What part did Cromell play in achieving the firot subraisoion of the clergy in Janaary 1531? Foxo (Acts and lionuments, .3671 .) makes hits alono reoponsible, but Lord Horbort 
the government is convoyod by the "Instmactions yovon by tho Kingeo Highnos unto hia trusty Counsaillor Thomas Crumoll, to be declared on his bohalf to hio Lerned Counsaill and indelayedile to be put in execucyon" in the lichaelmas Term 1531, ${ }^{1}$ which ohow Cromwell supervising the king'o logal buginoog, proparations for parliamont, and sizilar mattors which would bo entrusted to a purely executivo minigtor. His councillorohip did not make hiw tho loador of the council, the king's chiol minister, as Chapuys, Pole, and Foxe would have uo boliovo. But he ras gradually approaching tho hoighto. In Norember 1531 the Venetian arbarsador, in his roport on England, gave a list of the leading councillore rhich included Cromell as the serenth of the eight ren named.2 The same report, hovever, alob otated that Jorfolk had beon supreme bince Holsey's lall, evory employment devolving upon him, an opinion which was fully shared by Chapuys. 3 The fact that

(Henry VIII, p.348) sajrs that "some of tho.King'g Council together Fith Cromwel" perauaded convocation, a phrasing which might almost ouggest that he did not think Cromoll was yet of the council. In the absonce of contemporary evidence it is impossiblo to bo certain on this point, but it may bo suggested that tho position in which 70 887 Cromrell at that time, and rhich is illustrated by contemporary docursontary evidence rather than tho words of a panegyrist, maker it unlikely that ho played a moro than subordinate part. He may have as8isted; indoed, it is probable that ho did; but ho $7 a 8$ not tho loader in the business.

1. Stato Panerg, Henry VIII, i.380 (L.P. V.394).

2. Gardiner boing the 188t: Von.C8l. iv.694.

3. Span.Cal. iv(i).292, 416,460. 
Crompll was employed only in domostic offairs until tho boginning of 1533 naturally obscured hio groning importance to Loreign oboorvero who wore more likely to como into contact with Norfolk, Wiltohiro, Gardinor, and Fitatiliam. In the circumstancos, the Venotian ambasador'o inclusion of Cromvell in the innor council is an earnest of the position achioved by Crompoll by the ond of 1531. Thether ho bolonged to this inner circle frow tho otart it is iuposiblo to say for cortain; we think it unlikely in vior of tho evidence which shorred a gradual rise in the king's oorvice and favour. At any rate, by the latter part of 1532 his position raso ouch that experiencod offlcialo like Gardinor and sir Francio Bryan addressod him as "of tho Privy Council", and that he was included in tho commissions of the peace together with other leading councillors, as the custom ras. 1

Even moro definite proof of this upward novewent is tho fact that in the year 1532 Cromell laid the foundations of that large collection of officed which rere to him source of both income and porrer. In April ho ras appointed mastor or treasurer of the king'o jerelo, and in July keoper or clerk of the hanaper of chancery. ${ }^{2}$ crommell had made a position for himself oufficiently strong to allow of his holding

1. L.P. $\nabla .1245,1406$; 1694 (ii): Essex, Kont, Middlesox.

2. Ibid. $978(13)+1207(36)$. 
appointments and of his boing one of the fow moro important mombers of the council, but ot1ll modost onough to provont his snatching at any of the groater officos of otate or housohold.

After hio roturn with Henry from tho mooting with Francio I at Boulogno, Cromrell soomo to have taken tho last otep to achieve that place rhere Chapuyo firot took notico of him ao a posoible rival to Norfolk. ${ }^{1}$ By April 1533 ho nas doscribed as tho man with tho greateot influence over the king, and by lovember he ras "ruling everything".2 The long otrugglo for tho king'g favour was over. It was not by somo magnificont plan and suddon inspiration, or by some hidden oatanic inIluence, that Henry discovered the socond great minioter of his rejgn. By his hard mork and officlency cromoll had provod himself in tho king's sorvice, shoring himsolf a willing and akilful instmuent of the royal policy. Ho norked his ray up after ostablishing his personal oafoty by entering parliament with tho king's approval, and his riso ras bound up with definite positfons within tho adminiotrative machine. King's servant, king's councillor, mombor of the innor council, treasurer of the jerrels and other offices theoe rere the stages by rhich Cromell reached supromecy

1. Span.Cal. iv(ii).601,618.

2. Ibid. 644 ; L.P. $\nabla i .1445$. 
in the king's government. Ho founded his caroor on his work 0.3 an executivo minister and administrator rathor than os a political advigor, a choice of ground rich indicatoo whoro his poculiar abilitiog lay. 
Chaptor 2.

CRONTELL'S OFFICES.

I. Haster of the Jorrolo.

Cromirell was appointed master or troaguror of the king's jorels by patent datod 14 April 1532.1 Ho hold tho offico till his death, though at somo period of his caroer ho surrendered his patent for a new one, made out jointly to himsolf and to John Williams, principal clork of tho jorrolo.2 The exact date of thio patent is not knom as it meroly namos the regnal year, 27 Honry VIII, the year ending on 21 April 1536. It can be fized a little more closely than that. The master of tho jerols ras paid by the exchequer, and tho oalary is recorded as going to Crommeli alone until Michaolmas 1536.3 The first yoar in which Cromoll and Williams Fore paid jointly was the exchequer yoar 1536-7.4 There is no mention of Nilliams as master of tho jerrolo until the beginning of 1538 whon a grant $7 a 8$ mado to Thomas Cromell, keopor of tho privg seal, and John Filliams, troasuror of tho king'o jerelo. 5 The two offices are algo noted separately in the list of now year'o gifto in Decombor 1538.6 After that timo,

1. L.P. $\nabla .978(13)$

3. P.R.0.E $164 / 69$.

5. L.P. Xiii.I.384(98).

2. L.P. $x .776(1)$

4. P.R.0.E $405 / 203$.

6. Bjlitaryndej $4 S$ 97: $1.54 \mathrm{v}$ - lord privy geal; 1.55 - mastor 
reforences to Filliams in his now office are erequent, 1 and there can be no doubt that he succeoded as golo mater on Cromeli's death. 2 But the exchoquor accounts make it certain that from 1537 to 1540 tho office was held jointly by both. 3 Those accounts, mado up at Michoolmas, woro always a 1ittle bohind the times: it 188 rocordod at Michoolmas 1532 that the fee of the troasurer of the jorrolo rent to Robort Arader who had beon decd for some oix months, 4 and in 1540 Cromell mas mentioned rith Williamo despite bio oxocution threo months earlior. 5 The lact that Filliams was. not montioned at Michoelmas 1536 is not, therefore, prool that the regnal joar of the joint patont wag wrong, but together with the fact that wo do not find him called master of tho jorolo until a later date it goos far to prove that tho joint appointment was made rell towards the ond of 27 Henry VIII, that io to say, about April 1536. In Boptembor 1535 Crómell ohowed an interest in "the patont of the jerrol housen" and had a copy sent to himself by one of his servanto. 6 Presurably ho was thon beginning to think of sharing the office.

By a privy seal of 1485, tho exchequer had boen authorisod to pay various household officials, among them the "koopor of

1. E.g., L.P., xiii.I.903; xiv.I.67-8,905(8),1354(14); II.780(20); x०. $436(25)$ :

2. CI. D.N.B.; xxi.412b. His patent, if he was given a now ono, has not survived.

3. P.R.0. E 405/203-5.

B. P.R.0.E 405/205.

4. B.L. Add. MS 33376 .

6. L.P. ix.359,372. 
our jorrelo mithin our chamber". 1 The foo of tho office as otated in the patont was $\$ 50$ a yoar, to bo paid in equal portions at Hichaolmas and Lady Day, 2 and Crompoll'o privato accounts ohow that he received this oum and no more. 3 It 18 not quite clear what happonod aftor the appointmont of two joint holdors. One would suppose that tho foo was difIded, and indoed it ras paid in equal parto, and ooparately, to Cromoll and Williams in 1538.4 For the remaining throo years it ras all paid into Filliams' hands though it ront supposedly to both, 5 and ro cannot bo oure whothor Williams kept the total or made over £25 to Cromrroll. He may ouppose that the latter happened, for thoro could hardly be any roason for Cromell to continue holding such a minor office excopt the money which it brought him.

For it 788 a minor office, dosconded - 80 the privy seal alroady quoted indicates - Irom the office of the keoper of the

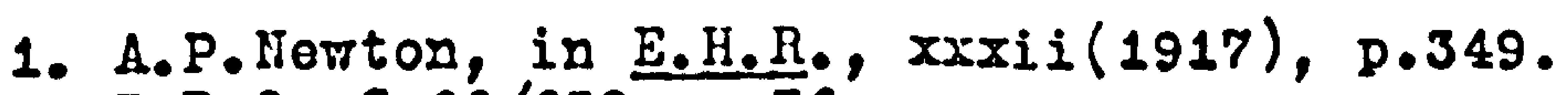

2. P.R.0. C 66/659, m.36.

3. L.P. Vi.841: half year's foo of the jerrel house - £25; ibid. ix.478: $\$ 75$ for the period Wichaelmas 1533 to Michaolmas 1535 (that is, \&25 each at Lady Day 1534 and 1535 and at Uichaelmas 1534, so that the exchequer muot have beon behindhand with.its paymenta). L.P. ti.135 gives Cromroll's accounts for Micheolmas 1535 to July 1536 and records \&25 as tho haIf yoar's foo of the mastership of tho jowols, oothat ro may ronder what had bocome of the $£ 25$ due at ulichaolmas 1535. The tollers' accounts for that year are misoing. Whatorer the answer, it is plain that Crommell drem at the most his official salary.

4. P.R.0.E 405/203. 5. Ibid. 204-5. 
jewolo in the chamber rather than from the kooperohip of the jerrolo in the Torrer. It 700 a housohold office, closely connocted with the chamber; in the time of Richard II the roceiver of the chambor had also boon keoper of certain ferrelo there. 1 Although jerrolo wore kept in various places, a opocial keoporship ovolved from this official, and when tho office of the jerrel-house became definite in the fifteonth century ito head was at times described as the kooper of tho king's jertels and at others as the treasuror of the chamber. ${ }^{2}$ The offices were combined under Edward IV and Richard III, 3 and as late as 1533 a royal official - Sir Milliam Skeffyngton, the master of the ordnance - could wake the miotake of addressing Cromell as treasurer of the chamber. 4 The keoper of the jerrelo was responsible for looking after the king's bullion reserve in plate and jerrels which 780 kept in the chamber, and until Henry VII promoted the treasurer of the chamber to a high position in the central financial adminiotration the troagurer tras as often as not more important for that part of his duties which rould wore accurately be described as the keoperohip of the jerrels. Horrever, the reforms of Honry VII separated the tro offices, and by advancing the treasurer of the

1. Tout, Chapterg, iv.197,204. Horrevor, another keeper of jerrels of the same period appoars to havo had no connection vith the chamber (ibid.334-5).

2. Ibid., pp.3361.

3. A.P.Nerton, in E.H.R., xxxii(1917), pp.3501.

4. L.P. Vi.1290. 
chamber renderod tho keepor of tho jorrolo of oocondary importanco. ${ }^{1}$ Cromoll's prodecosoor in tho offico, Robort Amadso, was a goldowith, a citizon of London, 2 who appoaro to havo been in charge of Molooy'a jorrolo beforo he took ovor tho kooperahip of the king's.3 Such trecoo as romain of hio activities shor that he was concorned only with jowelo and plate. Ho occura in the occounts of the troaduror of tho chamber 08 recoiving and paying monoy for such matters only, usually for plate given to ambassadors.4 Ao mastor of tho king's jerelo be did only such rork as a otrict intorprotation of the title cllors, and the appointment of a goldsmith ras both obvious and significant.

Such ras tho offico to which Cromoll gucceodod in April 1532. Its scope was baroly indicatod by the patent which eppointed hiw "Lagistor siue Thesaurarius Iosaliuw nootrorum" with the usual fcos, rovrards, and houoohold livory, and with an

1. A complication is introduced by Sir Henry Wyat, trocourer of the chamber from i524 to 1528, who rao also draming $f 20$ a year as mator of tho jorelo, at a tivo whon others, called treasurere of the jerols, rere paid their $£ 50$ (P.R.0., Doclarations of the state of the Treasury, panging. Thio is the only case where a distinction ras made botroen a master and a treasurer, and it is obviously merely one of convenienco to exchocuer officielo. Fyat drow his oinecuro money rithout doing any rork connocted rith jorrols, all of rhich ras in the hando of Crowmell and his prodocosoor Anadas.

2. Liats of Early Chancery Procoedings, $\nabla i .2,4$.

3. L.P. iv.1662,6748(5). Hia patent $7 a$ datod 20 April 1526 (ibid. 2114), but he ras acting in the office ao oarly 08 october 1524 (ibia.695).

4. L.P. V., pp.3iा, 315,316,319,321,323, 325 . 
annual oalary of $\$ 50.1$ Ho was aloo givon the power to appoint a yooman and groom of tho jorel-houso to sorvo undor him and during hio pleasuro. Hio orm appointment, in accordanco with procodont, wag during good bohoviour. Tho patent oaid nothing about any porors to appoint a auficient doputy, a fact vinich may explain why Cromvell went to all tho troublo and exponoo of sharing tho offico whon ho himgelf could no longer look aftor it. ${ }^{2}$ Ho thus hold an offico which by a fairly rocont tradition had becomo no moro than tho custodianship of tho king's plate and jorrolo, but rhich had at ono time ro far overahadorod even tho treasurer rithin the chember that officialo holding both offices mere comonly called by the title of the former. It ras primarily a financiel office, the first of any importance to fall vacant aftor Cromroll's entry into the royal service and favour, and it soowe clear that Cromroll took it for that roason. His firot alaijod appointcont in the king's service gavo him the place of a minor cog in the adminiotrative machine of the royel financeo.

Ho carried out the basic dutios of the office, that io, ho personeliy lookediefter the king's jerrols and plato. In September-October 1533 notos about such matters appeared in his "remembranceg". 3 The king'o goldsmith delivered plate

1. P.R.0. C 66/659, m.36.

2. Snother reason may have beon his desire to promote a faithful servant (and kingman?).

3. L,P. vi.1194,1382. 
to his in 1534, and although the tranoaction io rocordod as hoving boon mado with liastor socrotary, it was rathor as troaouror of the king'o jerrols that Cromoll was concornod in $1 t^{1}$ Ho took chargo of the plato roceived on now year's day 1534,2 and in all probability aloo of the plato coming to the king whon bishop Fishor wao iapriooned.3 In Fobruary 1535 a ourvoy of jorolo deliverod to the coldowith for altorationo was carried out by his peroonal gorvanto, sadlor and Vaughan. 4 It ras this attention to tho smallost detail which raisod him to porfor, and rinich gave his career much of its outstanding importanco in the history of adminiatration. A similar caro for efficioncy was shom by his co-opting to tho offico, when his orn immodiato control had perforce to ceaso, a man who had six years' practical exporience of its dutiog. 5

Though Cromell by ho moans neglectod the tasks fundementally associated with tho office be did not content bimsolf with them. The details rili be rorked out in another chapter, 6 but fie may here sumbarise its conclusiono. As mastor of tho jevelo Cromell turned hio private office into a department which collectod cortain small revenues and handled a largo expenditure. The mastor ceased to adminioter only bullion

1. L.P. Vii.1668.

3. L.P. $\nabla i i i .888$.

5. Wiliams ras appointod clerk of tho jowols in April 1530 (L,P. i . 6418[8]).

6. Cl. bolor, Chapter 3, Soction II. 
and doalt with large amounto in cash and bonds. Ho rivallod, and in a meacure superseded, the treasurer of the chambor as head of a sponding department which financod waro and garrisons, and largely contributed to the day-to-day expondituro on retrardo, buildings, naval affairg, and a dozen other purpooeg. For income he relied mainly on equally irregular sources, ouch as repayinento of debto and fines for knighthoode, and in particular on reserves from the royal colfora. Cromell wishod to have plonty. or: money ready to hand in order to be able to govern Ireely and unimpoded by depondence on other departaents, and he used the mastership of the jerelo to give him that froodom.

Such a dovelopment naturally dopended on the man. The wester of the jerrels usurped considerable functions only as long as Cromtrell held the office. He created no organised department. The officials allored to him by his patent, the yeoman and groom of the jerrel-house, were omployed only on wattere directly connected with jerrels. Tho businese which Cromroll added to the dutics of the office was trangacted by himself in person, with the asgiatance of his orm household servente, three of whom in 1535 held his porrer of attorney to receive all money due to the king in his nare. ${ }^{1}$ Thuo the offico dropped back into relative unimportance when he 
rolinquighod 1t. Milliams might otill bo ontrustod with paymonts to the troasurers of Borvick and Iroland, 1 but vory largely he reverted to the dutios of a keopor of tho jorrolo. The jorrol-houso continuod to bo a troasury which could bo mentionod together with the chmbor, tho court of augmontations, and the oxchequer. 2 horrovor, as the ropository of tho normal resorvos of the ago, jowols and plate, it would naturaliy and without Cromell'o prork have hold an important place awong royal treasuries. Tho significanco of Crompoll'a tenure of the office lay rather in the fact that ho had mado it into a major apending departmont. Sir John Milliamo, lator to bo first baron Thamo and chancollor of tho court of augmentations, was a moro important man than Robert Amadas, citizen and goldsmith of London. By that mossure the importanco of the offico had incroased as a consoquence of Crommell'o wastership. In the financial adminiotration of England, horever, it did not keop tho place given to it by Cromell. Crommell's mastership of the jomols is of the groatoot importance in his own career, boing hio first post and one which shored what ho could rake of eren tho most colourless office, but it loft no enduring mark on adwininotrativo organiaation. 
II. Clork of tho Hanapor.

The offico of kooper or clork of the hanapor of chancory 780 grantod to Crommoll by a patent dated 16 July 1532.1 Ho hold it until his death but ourrondorod his patont for a nor one, made out on 24 April 1535 to hineolf and Relph Badler jointly. Thio patent doos not appoar to have beon enrollod but survires in a copy in a procedent book of the Cromn office. 2

The cleris of the hanaper was the official in charge of the profits of the great soal, that is, he was the treasurer of the chancery. 3 The office was not, indeed, a major ono in the organisation of the government, but it rag of $80 \mathrm{mo}$ importanco. An ordor in chancery in 1622 declarod that it had alrays been one of great trust and involving considerablo business for tho clerk who had to be in continual attendanco on tho groat seal, oithor in poroon or by doputy.4 Ho rao only a clerk "of the second form", but had beon a man of some standing as early as Richard II, 5 and tho order just quoted

1. L.P. V.1207(36).

2. P.R.0. C 193/2, 11.618-64. Thero is the lese doubt about this patent having actually boen granted because the hanaper accounts name Cromiell and sadlor together from Lichaelmas 1535 onrarda (P.R.O.E 101/222/8).

3. C1. Tout, Chapterg, 1.286: "The keeper of the haneper rec- oived the lees of tho seal, paid tho oxpenses of tho chance ory organisation, and prosented the cccounts of tho adwinistration for rovior."

4. Sandors, Orders in Chancory, p.135.

5. Tout, chanters, ii.444. 
oayo, arong other things, that "tho clorkoo of the Hanaper herotofore wore men of great accompt, as the Lord Cromell Earle of Essex". Cromoll's joint kooper and successor, sir Ralph Sader, was principal oocrotary and koopor of tho groat Fardrobe whon he held tho office. Though, thereforo, it rould be wrong to claim that the clerkship of the hanaper was in itsolf vory important, it is clear that it could moll bo hold by mon aspiting to importanco.

The Lees and emolumento which Cronrrell ras to recelve mere described in his patent. ${ }^{1}$ First came the traditional oalary, "vadia leoda robas s regardia quocumquo oidom officio aliquo modo ab antiquo debita sonsuota". These had for centurios consisted of oixpence a dey, that is $\$ 9.2 .6$ a year, in $10 e,{ }^{2}$ and of finter and summer robes for which the keeper recolved 22.6 .8 in cash. 3 secondly, the patent of appointment granted an annuity of $\$ 40$ chargoable on the revenues of the hanaper, and lastly, Crontrell was to recoivo the sum of 18.6d. for every day opent "attendendo \& equitendo curfancollario nostro Anglia". Me aro told that as oarly as 1516 this gum had become stereotypod as 1s.6d. For every day of tho yoar, 4 but, as a wattor of fact, the first yoar in which a foo for

1. P.R.0. C $66 / 660, \mathrm{m.33}$.

2. Laxroll Lyto, Great Sorl, p.284.

3. C1. expenso accounts of tho hanpper, O.g. P.R.0. E 101/222/ 11.

4. Laxrrell Lyte, 10c.cit. 
365 days was paid was tho first of Edrard VI (1547), after which this sum of $\$ 27.7 .6$ rag paid regularly yoar aftor yoar. ${ }^{1}$ The accounts show that while Cromell held tho offico at loast a pretonco was kopt up of paying only for dayo actually opent on duty. 2 Tho clerk of the hanaper could, thorefore, oxpect to drar $\$ 51.9 .2$ plus an averago of about 200 dayo at elghtoonponco each, a rough total of $\$ 65$ a your altogother.

In addition to that there rould bo the unofficial income, but here rie can hazard only the vaguest of guesger. The chancery order of 1622 atated that "one of the choifost proflitts belonginge formerly unto the said offico of clorke of the hanaper was the rocipt of fynes for all licenses and pardong of alienacion rritto of corenant and writts of entry for recorerlog", no doubt a considerable sum, for it was the granting array of those profito ("which woro auncyontly payd into tho hanaper") under Elizabeth which led to tho order appointing very largo foos for the clerk. 3 But did theoo profits go to the clork or to the office? The fines montioned nere accounted for in tho hanapor accounts, and tho complaint in 1622 ras that oring to their disappearance the

1. P.R.O. E $101 / 224 / 7$. In 1544 only 278 dayo nore charged against the hanaper rerenues (ibid. 224/2), and no accounts survive for the two yearo folioming.

2. The knorm figureo are 192, 194, and 213 days for the yoars ending Uichaolmas 1535, 1536, and 1540 (P.R.0. E 101/222/7 and $11,223 / 6)$.

3. Sanderg, Orders in Chancery, p.136. 
office no longer paid itg ray. As was tho comon practico of the tira, the clerk could pocket as profit what ran left after he had paid the expensoo of his offico, and it sooms that that was littlo enough. On the othor hand, it is possible that ho was rocoiving alroady in Cronmoll's time tho tro shillings for the sealing of ovory "perpotulty" which ho cortainly recoivod later, ${ }^{1}$ and which did not go into tho official accounts, but nothing is knom for certain. At any rate, tho office provided a reasonable income for a minor official.

The question of hor ruch Crommoll got from the hanaper is complicatod by tho fact that tho official accounta toll a difforent atory from that revealed by his private accounto. If we believe the petitions for allowancos presented by the clerk, ${ }^{2}$ all the fees listed abovo nero paid out year by yoar, allorrance being clained regularly for the kceper's aalary, robes, and annuity, and for a spocified number of dayo of the spocial allorrance. Horrever, the date of an account is small guarantes for the date on which it ras actually made up, and these petitions appoar to be in genoral rather schenatic and stereotypod. Nor vore salaries normally paid in tho sixteonth century on the day on which they rore due. The mention of a

1. Lasmoll Lyto, Groat Soal, p.336.

2. Those surviving for Cromreli's keepership are P.R.O. E 101/ $222 / 7$ and $11,223 / 2$ and 6 , for the yoaro onding Nichaolmas $1535,1536,1539,1540$. 
payment in an account doea not, therolore, nocossarily provo thet the payment was ovor made at all. It cortainly provoo nothing for the date on which it was made. Cromvoll'o accounts tell a ourprioing otory. Durine the period from Janary to July 1533 he recoived a sum of 66.17 .4 , otatod to be the revenues of the clerkohip of the hanapor. ${ }^{1}$ This seems reasonable enough: something orer $\$ 30$ would have been due in 1000 in that half year, and tho balanco was medo up of thoso unofficial profits on which j.t is genorally supposod officiale of the period lived. But what are we to make of the fact that for the tro years onding at Michaelmas 1535 ho had only $\$ 58$ from the hanaper? ${ }^{2}$ At the very least, ovon leaving out tho troublesome eighteenpence a day, somothing lick $\$ 100$ ought to havo boen expocted. For the hall year which followed this account Cromeli received $220.6 .4,3$ broken down in the account into items: his half year'o annuity ( $\{20)$, foe at sixpence a day (24.11.3), pinter livery ( 1.6 .8 ), and a fee for his clerk at fourpence hal fpenny a day which is not mentioned at all in tho official hanapor accounts. There it came from must remain a myetery; apparently Cromrell managod to put a personal clerk on the haneper establishrjent and drer wages for hin which were not accounted for in the annual account. It is conceivable 
that the clork in question might bo Cromell's doputy, the underclerk of the hanaper, but the accounts provido no trace of such a sum boing paid to him, either. Aloo it was tho underclerk who paid the money to Cromwell't sorvanto, ao io noted in Cromell's accounts, and wo should thereforo have to asoume that the money rent from him.to Cromsell's privato coffers and later back to hin again - surely a noodless and unlikely corplication. ${ }^{1}$

Horrever that may bo, we must noto that after the firat belf year ro cannot find any sign that Crommell was receiving large sums in customary but unoficial foes. In fact, he barely got the minimus due to him, and it can be said thith some certainty that he did not drat the 18.6d. a day for special expenses to whibh his patent entitled him. Thoso oums, horiever, appoar year by yoar in the hanaper accounts. That became of them can only bolsurmised. Cromroll'd patent declared that in coneideration of the heary costs, expenoes and burdens which the same Thoras Crommell or his deputy Fould have to bear by reason of his office in attending and riding with the lord chancellor "dodimus \& concessimas eidem Thowe Crumell decem \& octo denarios" for every day thus opont.

1. A further difficulty is introduced by the fact that thio full half year's foo ras received at a time when Cromrell was sharing the office mith Sadler who suroly did not go vithout a share in the profits. Hould he porhapo receive the feos for the second half year? 
Yot, excopt posoibly right at tho beginning of hls tonuro of ofico, Cromtrell did not draw this money, and it soomo moat iikely that it rent to his deputy, tho underclerk of tho haneper, who did all the rork but ostensibly rocoivod only the sur of one mark for his vinter robe from the hanaper. ${ }^{1}$ The accounts uoe a rather curious phraso, dogcribing the money as spent "pro expengio equorum circa attendentium cum Cancellario", a wording which leaves it open who actually received the money. ${ }^{2}$ As there is nothing to show that Cromell received the customary profits due on cortain inotrumente under the great seal, it is moro than likoly that these also vent to the active official, the underclerk. Cromell clearly did not uee the clerkship of the hanaper for the purpose of enriching himself, receiving at most his basic Lees.

1. P.R.O. 3 101/222/11.

2. Dorm to the keepership of Thomas Hall the phraso ran "in expensis dicti Custodis de deputati sui equitantium cum domino Cancellario" (P.R.O. E 101/220/7). Perhaps because the fiction of a traveling chancery could no longer be maintained, it ras then changed to "pro exponois equorum" (ibid. 221/10; used for the last time in 1544: ibid. 224/2). The change to a fired payment for 365 days conincidos tith another chenge in the rording. The money ras theroafter spent "pro omnibus custubus \& exponsis dicti Custodis in oeruiciendo domino Cancellario" (ibid. 227/8): the pretence that opecially arduous dutieg rero to be covered by 1 t had been given up. It may not ve fanciful to connect the last change wi th the appointment of John Hales as Sadler's partner in October 1545 (P.R.0. C 66/785, w.34), and perhaps With lord chancellor Wriothesloy's orders of Way 1545 part of which is lost (Sanders, Orders in Chancery, Pp.81.). 
It is oqually plain, howoror, that ho did not hold tho office for the purpose of carrying out its dotallod duties. There is an occasional trace of hio acting in his capacity ao clerk of the hanapor. He attended whon tho groat soal was banded to the now lord chancollor on 26 January 1533, and ho is followed in tho liat of pooplo prosont by poxarl, clork of the crom in chancory, croke, firat of tho oix clerks and controllor of the hanapor, and Judde, undorclerk of tho nanaper. 1 It is very likely that ho attonded a function intimately concerned with chancery business, and in the company of permanont officialo of the chancery, rather bocause he ras a chancory official himself than bocauso of hio genoral position about the court. Admittedly, tho other wen present - Norfolk, Cranmer, Wiltohire, Gardiner, Fitzwilliam, Peulet - wore loading officers of state and household who had nothing to do with the chancery. But unless 70 are prepared to say that Cromell alone was tinoro because of his general position rather than because of his office, the fact thet all the others hold offices otrangthons the supposition that ho was there as clerk of tho hanapor.

A for other examplos of Cromroll apparentiy acting in tinio capacity can be cited. An indonture of Auguat 1533, by which tho frardens of St. Olave'g, Southrark, bound thomsolvos 
to pay to him, for the king'a uoe, a fine on purchaging landa under a patent lately granted to them, deacribos him as clerk of tho henaper. ${ }^{1}$ The collection of fines payablo undor the torms of a patent and not for its oealing did not, strictly spoaking, belong to the hanepor, and it is thorefore unlikely that the degignation had any coministrative significanco. mhere also survives one of the undoubtedly large number of rarrants exemptine the boarer frow the peymont of fees in the henaper.2 This is an order under the sign manual to delivor to Anne Boleyn the prtent creating hor marchionego of Pombroke, "without taking any fine or fee for ve or to our vee for the seales", and is addreseed "To our right trasty and velbiloued Coursaillour Thosas Crumell, keper and Clorc of our Hanapor in our cheuncery, and in his absence to his doputio". 3

It may, horrever, be doubted whother Cromell over oor this varrant or handled Anno's patont, and it is woro probable that tho matter ras attended to by "hio deputie". It is as clear as the meagre evidence will aldon that John Judde, the underclork, saif to tile routine mork. It rao he who paid the keopor's emolumento from the henaper to Cromoll's oertants, and who paid to him as mester of tho rolls the profits

1. L.P. vi.970. There is a copy in a precedent book, P.R.0. C $193 / 2,1.13$.

2. Lany of the items in the hanaper accounts are marked as "pardonatur" or "excusatur per rarrantum regis" or "por cartam", or $\nabla i$ th oome oimilar phrasc.

3. P.R.0. E $163 / 10 / 19$. 
due to that office out of the hanapor. ${ }^{1}$ In Soptember 1535 he received from Crommoll the fco for the sooling of hio patent as master of tho rolls. ${ }^{2}$ His succesoor, Richard Snorre, wrote to liriotheoloy in 1538, iskini for the foe due on a "book" sealed in the chancery. 3 Judde had boen deputy to Thomas Hall, Cromell's prodecossor, and was apparently left in charge then Hall died. Some time in 1532 ho handed over to Cromell the sum of $\$ 300$, described as the profits of the hanaper in Hall' $\varepsilon$ time. 4

In August 1532 Judde wrote a letter to Croumell which doserves quoting at some length because of the light it throws on the administration of the hanaper. 5 It otarta: "Please it your Haistership to understond that I haue receyued your letter... Wy lorde of the greate soale hath sealed the patent of Armys, at the sealyng of which patent I fas at Ippistich." Apparentiy the presence of cboth. the clerk and the underclerk at the sealing could be dispensed vith, though the provision of eighteonpence for every day spont in attending the chancellor implied a theory that one of them had to be there. In Judde's absence things had gone wrong: "For, and

1. L.P. $x i \cdot 135,66(i)$. 2. L... ix. 478 .

3. L.P. Iiii.I.1490.

4. L.P. $\nabla .1730 ; \nabla i .228(\$)$. Hanaper surpluses usually ront to tho chamber (L.P. Xiv.II.13), but in this caso Cromoll seems to have used them for his om financial ministry (c1. belor, Chapter 3, section II)

5. P.R.0. SP $1 / 70,1.207$ (L.P. V.1214). 
I had ben at thonooalyng of it, it shuld hauo bon ooalod rith Ereno wax and lacia of eylke, whicho cannot norro conuenyontly bo don by cause of tho cutto that the angnus is in." Ho wont on to elaborato somo detailo for tho bonofit of his now ouperior: "For it is a porpotuyto graunted to hym and to hio hoyros, whiche must pay for tho soale to tho kyngos highnoo viij Ii'ix g', oneles your liastorship do attoyno a rarraunt for tho discharge of thesame. For and if the kynger hightnog govo but Iyconco to eny man to Inparke any grounde, or to Inbatell his houso for hym and his hoyros, it is a porpotuyto and shall pay viij li' ix s'." Cromtoll probably nooded this instruction. He hed not beon trained in tho chancery and its rules pore no doubt otrango to hir, a oufficient reason for leaving the day-to-day rork to an experienced underclerk. But horverer little of tho actual fork ho may here done it ras not in his nature to neflect any office or to leare his deputy a completoly froo hand, and Judde concluded by assurinis him that "at my comyng to london I will resorte to your seid Lastership to knowe your ferther pleasar."

Cromell's activo intereot io ohom in other thingo. He possessed arong hio papero a "roll of the chargo of the clerk of the hanaper" and one describod as a roll "of Thoma Hall, late clerk of the hanaper", that is to say, accounto 
or ootimatos of hanapor oxpensog.1 Rocoipts for paymonto from the hanaper show that, although tho money was profosoedly roceivod from the clerk, it was tho undorclerk who did tho actual paying.2 Thus the troagurer of the chamber, or rather hia clerk Thomas Carmarthen, received on 8 Deceruber 1538 the sur of $£ 200$ "Do Thome domino Crvmoll Custodo Privati Sigilli domini Regis ot Radollo Sadlor cloricis Hanaporij Cancellario dicti domini Regio por manuo Ricardi Snoro". 3 Those recoipts also shor that in co-opting sadier to tho office Crombell was not looking for someone to do the routine work. He ras doing Sadler a favour, and he may posoibly have left the general supervision more to him. The normal Fork of the dopartment, howover, continued to be done by the undorclork.

It cannot therefore be doubted that Cromoll did not spend hio timo in the detailed administration of the hanaper. As ho did not recoivo large oums from tho office, it must bo concluded that he held it for the sake of boing ablo to exercise a general supervioion and control over this branch of the administration, and we have been ablo to produce somo ovidence, though littlo enough, to support a vior which is convincing in itgolf.

1. L.P. $\nabla i .299(i x . E) ; \nabla i i^{2} .923(i, x i j)$.

2. A for of these recoipts ourvivo, sowo of them mutilated: P.R.0. E $101 / 222 / 12$ and 15 .

3. P.R.0. E $101 / 222 / 15$, no.1. 
It therefore becomes important to know why such control soemod desirable, that is to say, what the scone and plaoo of the hanaper rere. It has alroady boen indicated that the keoper of the hinaper was esoontially the official charged With the financial side of chancery business, with the colloction of its profits and the peymont of ito exponses. $\Lambda$ little more detril nor becomes necoseary. The hanaper accounts doal rith $\varepsilon$ number of sources of income. 1 There rere the fees for the gealing of all documents issued by the chancery, as well as fines payablo on cortain typos of granto: these made up the incowe of th: chancery proper. There foro further tine feos payabie for writo oued out of tho courts of justice, collected there but delivered into the hanaper whoro they wore accounted for torm by torm. Lastly, thero rore a number of smalier source日, such as fines for the restitution of the temporalities of ecclestastical benefices, or fines on the bonds knorn as statutos staple. It is difficult to arrive at any accurate totals, for where a chock is possiblo the figures invariably disagreo. ${ }^{2}$ But it can bo said that Income in the hanaper fluctuated botreon about $\$ 2000$ and

1. The hanaper accounts for the period are preservod anong the various accounts of the exchoquer, P.R.O. E 101.

2. The dotailed account for tho year 1533-4 adds up to a totol of 82069 (P.R.0. E 101/222/4), whilo the rbotractod atatemont of account giveo 22886 (L.P. Vil.1204). A oimilar discropancy existo for 1538-9 thore tho figureg are $\$ 2279$ and 22486 (P.R.0.E 101/223/1; L.P. xiv.II.252). 
23000 a year. The significant figures, howovor, are thboe of eurplus aftor the expenses had been paid, and thooo avoraged somothing like 1200 a yoar, though here agnin thero were conoiadable fluctuations. Of this the better part ront to the treanuror of the chamber who could expect betwe on $\$ 800$ and $\$ 1000$ from this source. Tho balance romainod in the hanaper.

The chancery thus oupplied a not inconsiderable oum every year to the royal revenue, the chief morit of which must have been ito rogularity and roliability; Tuke, tho treasurer of the chamber, doscribed it as "the hamper money whiche was ront to be to we a good shoteanker". 1 This revenue was controlled by the clerk of the hanaper. Ho have found ourselves compelled to discrird tro motives which wight explain Cromrell's tenure of the office, namely that it wao oither a sourco of realth or a meang of employment to him. There remains the third which ve have beon able to discover, that he rished to control it; for thie we heve now supplied the reagon. The hanaper attracted him as an independent and inportant financial department, as in esoential part of the financial adminiatration.

1. P.R.O. SP 1/153, 1.9 (L.P. xiv.II.13). 


\section{Chancellor of tho Exchequer.}

Crommell noxt acquirod the chancollorohip of tho oxchequor, his patent for which was dated 12 April 1533. 1 Thio toa not as yot an important position in tho financial adainistration. The chancellor of the oxchequor pas the doscendant of the chancellor of England's clerk at tho oxchequer table, and his dutios wore confined to the uppor oxchequer. $^{2}$ By the reign of Elizabeth he ras the socond officer in the exchequer, having "in Court the proper placo of the Bonch abovo the Lord Troesuror". 3 But such doos not appear to have boen his position in oarly Tudor timeo. Fe are told that until the first fruito and auguentation officeo were inclinded in the exchequer in Lary's reign, that is, until its ancient preominence had been restored to the exchequer, the lord treasurer rarely attended the exchequer court, leaving his duties there to the chancellor, the undertrossuror, and the barono. 4 of all these the chancollor was the lowest paid and therefore the least important. 5 In the court the chiof baron preaided, and he and the other barons did the rork; in the loter exchequer the undertreasurer supplicd the placo of

1. L.P. Vi. $417(22)$.

2. R.L.Poole, Exchenuer in the Trelfth Century, p.189; A.P. Nowton in E.H.R., $2 x x i i(1017)$, p.353.

3. Sir Thomas Fensharre, Practice of the Exch, Court, pp.191.

4.. Ibid., p.13.

8. Cf. the "Declarations of the State of the Treasury", P.R.O. E 405 . 
hio mastor, tho lord troaguror of England, who wao also ox efficio trosourer of the exchequer. 1

The chencollor's dutios aro somorhat obocuro. It appoaro from an order sent to the exchequer on Cromoll's appointmont that he kept tho soal of the court and exercioed a cortain amount of control over its rocordo.2 A oixtoonth contury disquigition on the exchonuer, proserved in a precedent book, 3 quotos tho Dialogus as saying that no groat thing should bo dono in the exchequer nithout the consont or counsel of the chancellor, but this is clearly o miounderotanding, for tho chancellor referrod to in tho Dialogua is the chancellor of England. The treatiso admits as mach whon it goos on to say that there is no traco in tho rocordo of the chencollor of the exchoquer giving judgmont in oither lar or ecuity, oither alone or jointly rith the treasurer and barons, of hio dealing rith any debts, taking accounto for tho king, or being put in authority by any of tho king's orito or atatutos "to doo anj of these thingo, which have \& boo not only magna but maxima in scaccario". All those things had almayo boon dono by the troasurer and barons, singly or conjointly. Tho writer then deocribed what $7 a 8$ in his vion tho chancollor's

1. The origin of the undertreasureris office is obscure. Poolo makes him the descendant of tho treasuror's clork (opecit., pp.1891.).

2. P.R.0. E $159 / 312$, Comunia, Eastor Term, Recorda, m.3.

3. P.R.0. E 369/118, If.13-15. Thero is a copy at the Brition Luseum (Tit. B.iv, $1.55 \nabla$ ). 
proper ophore: ho appointe the controller of tho pipo and tho clerk of the common ploas, keeps the soal, and is usually 10arned in tho law. Finally, he referred to the changes made in tho offico "recently", that is to bay, in Lary's roign, as a consequences of the reform of the exchoquer thon carriod out. Theso changes wore ombodied in a writ of 10 July 1559 which described tho now work to bo dono by tho chancollor as a result of tho onlargement of tho exchequer and asolgnod him now fees. 1

It is cloar, therefore, that up to tho middle of tho oixteenth contury the chancollor of tho oxchoquer was a minor official. Ho must not bo confuood ofith tho undortreasurer; $^{2}$ although the two officos came to be hold by the oame man they rore definitely separate. 3 cromoll'g successor, Sir John Baker, was the lirot man to combine them, and in Cromell's time sir Hichard Heaton was undertreasurer, naving succeoded Sir Thomas lore in 1528. Thus tho chancellor had not, by virtue of his office, any dealings with tho lowor exchoquer whore rocoipts and issuos wero adminiotered, and his place - an inforior place, at that - was in

1. There is a copy in B.Lf. Lanod.MS $168,1.274$.

2. Even Dr. Dietz as8erted that the "Declarations of the State of the Treasury" rere made by the chancellor (Engegov. Fin., p.234), whereas the documents themsolves otate explicitly that they rere oubmitted by the undertreasurer.

3. Even in the nineteenth century the same man rould otill hold the tro offices by different petento (F.S.Thomas, Notes on Laterials, pp.111.,15). 
tho exchoquor of audit, as a kind of ouporior clork without any particular influonce or control. His oath ahowo that ho was mainly employod in the soaling of writo; ${ }^{1}$ as has already boon romarkod, the custody of the exchequer seal was his most definito function, apart from the patronage which bolonged to him. In the reign of Elizaboth he held lour offices in hio gift, those of the controller of the pipo, the clork of tho ploas, tho clork of tho ninilo, and the soalor of the court; ${ }^{2}$ tro of these offices moro declared to bo hio by traditional right in the treatioe quoted abovo. But howover small its recognised ocopo may have boen, thoro woro possibilitios in an office rhich ontitled its holder to a seat in the exchoquer and put no groat opocific dutios on nim. It might be turnod into a oinocure, as it was by Cromell's prodecossor, Lord Bernoro; 3 but for that very reason it could be mado into a post of importanco, as ito subsequent developmont shors. To have hore ono example of Cromell'o fondness for offices mith an ill-defined scopo

1. B.H. Lansd.MS 168, 1.280 .

2. B.L. Harl.US 5174, 1.54 ; Langd.us 171 , $11.408,410$.

3. Bernerg ras appointed chancellor of the exchequer in May 1516 (I.P. il.I.1946) and hold tho offico until his death in 1533. During most of that timo ho 783 also deputy at Calais (cI. his lifo in D.N.B., ii.9201., and additions in Bull., vili.107). During 1532, e.g., he spent all his timo in Calais (E.P. $\nabla .787,857,1041,1219,1543$ ), and thero is only one montion of him as chancellor of the exchequer: in that capacity ho nas ored money by tho rardrobe (ibid. 1710). 
which loft much to the will and onorgy of tho individual holder.

Cromizell had shomn an oarly intorest in the oxchoquer. Evon bofore October 1531 he had acquired various documonto connectod rith it, as for inotanco a paper doclaring tho exchoquer to be the highest court of rocord - porhaps an early troatiser on the exchequer which wo should give a good deal to possess -1 and a nursbor of exchoquer accounto and declarations by customers, tellers, and an undertroasuror. ${ }^{2}$ Later he added documents which prove a groving interest in the chancellorship: a copy of the chancellor'o oath, a copy of Loroll's patent of the offico, an abstract from the Rod Book of the exchequer. 3 It rould seem, therefore, that he intended to control the exchequer, that he riohed to give concrete shape to this control by acquiring an office thore, and that he decided on the chancellorship.

He held the office from April 1533 until his fall. His patent allored the eppointment of one or more deputies, but there is no trace of any being appointed; it also granted him all lees and rights which his predecessor had had, and assigned him robes out of the great vardrobe. Financially,

1. L.P. $\nabla i i .923(x i i)$.

2. Ibid., 923 (2riii). The Hasilwood there mentioned ras ono of the tellers of tho recoipt, while sir John Cutt proceded Lore as undertroasurer.

3. Ibid. $223(x i x, x 2 \pi, x x x i v)$.

4. Printed by Rymer, Foedera, xiv.456. 
tho offico was rorth littlo. Tho chancollor's annual 100 wao \&26.13.4, 1088 than that of tho fourth baron, rhilo tho lord treasuror drom 2365 , tho undertroasurer $\{173.6 .8$, and tho chiol baron 2100.1 Cromroll's accounto wow that ho normally rocoirod this foo and no moro. For tho half-yoaro onding in Warch 1533 and 1536 he receivod $£ 13.6 .8$ oach. ${ }^{2}$ For the two years ending at Licheolmas 1535, horrover, ho got \&65.10.0, or aome $\$ 12$ moro than hio galary rould account for. 3 If this $\$ 12$ constitutod spocial picisings for a poriod of tro years they cannot be said to havo amounted to much, and altogether the emolumento of tho office woro hardly great enough to bo its privo attraction. The porroro of tho office, ouch as thoy woro or could bo made to bo, noro a more important point in its favour.

Although Cromeli's appointmont was dated 12 April, it was not until the 24 th that a writ was sent to tho exchoquar otating that "cortio de causis" it vas deoired to lind out what foos, rights, and porers attached to tho office of chancellor of the exchoquer, and ordering the barong and treagurer to eearch the rocords and notify tho chancory of the rooult.4

1. "Declarations of the statio of the Troasury", pasoim. It may,

$\therefore$ horever, bo taken 00 ono of tho first oigno of a greater ixportance attaching to the chancellorchip that these doclarations elmaja put tho chancolior firet in thoir list of saleried officialo, i.e. bofore the barono.

2. L.P. Vi.841; xi.135.

3. L.P. ix. 478 .

4. P.R.0.E 159/312, M.12. 
Having thus foliliarised himself rith his nor offico, Cromell appoared in the excheruer on the 30 th to bo admitted to opfice and to erroer his octh bofore the berons. 1 Ho alno brought with him a writ which spocified among tho things which cbould be handod over to him "sigillum dicti scaccarij nostri necnon rotulos memorand' rocord"".

It in not easy to discovor to what oxtent ho oxercised the chanceilorship. He used its poryors of patronage end appointed to the office of cloris of the ploco in the oxchocuer tro wen ono of thos, Willian: Erehazor, had boen his orn servant and rust have been an absentoo official ao he was undertroasurer in Ireland at the time. ${ }^{2}$ It rould also appear that he put in a fairly regular appearance in the court. At any rato, it was noted in Elizabeth's roign that "only this is remembrod by some auncient of the Court yot living that Tho: Crontoll, being Chauncellor \& the $K^{8}$ Secretary \& after $L^{d}$ privy sealo, did take place vppon the first bench cz dextra doxini Thesaurarij; but Sir John Baker, being the next Chauncellor, \& after vndertresorer also, did elrayes git rppon the second Bench where the vndertreaoorer now doth. And Sir Nalter Lildmay, next Chauncellor after hic, did take place be sitt whore the L: Crumell did, but by what authority or reason

1. Ibid. Commia, Easter Term, Recorda, w.3.

2. The offico $7 a 8$ conferred by Crommell's deod of 27 April 1538 and confirmed by patent in the January following (L.P. Xiv. I.191[31]). 
tho Chauncellor heth ritton in thosc rovorall placeo it app-

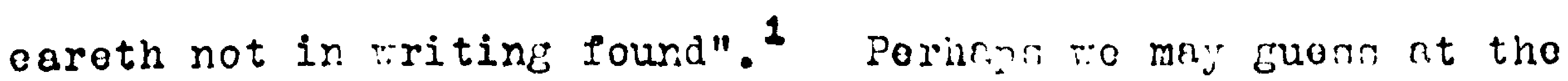
reason nnd euggest that Cromell usurper: the roat on the firet bonch, theroby sotting r procedont wich i.ilcmay follored though Baker rias too prudent or porronelly unii,portent to do so. It is likely that Cromell invostod the chancolloruhip with some of his own irportance. A chanceilor of the exchoruer tho in other ceprejties governed as the king's chiof minister could not be axpected to taiso en inferior place in the exchequer.

It is this question of his various capscities, and of the importance rbich attached to his person rather than to his office, rhich makes it diffialt to be cortain hor far he acted as chancellor of tho excheruer. Whon he appears in the exchequer recorde as acting in the court he is nearly alrays designated by that title, though sometimes sorie other office, gecretery or lord privy seol, is also mentioned. He used his position in tho exchocuer to appoar there as the king's wouthpiece. The rocord of an action against one Hilliam Evan, rerchant otranger, for tranggreseing a statuto of Honry VII concerning the import of Gascon rine, broaks off with the noto: "Bon fiat hic vitorius exocucio per mandatum Regis, nuncianto Thoma Cromoll Armigero Cancellario huius Scaccarij, quousque 
ac."1 Tho caoo of another merchant otrengor, John Tolargo, which belongs into 1540, shows him acting in the court togothor with the barons; apparently he had given the chancollor oufficient otanding to wake hin part of tho rogular judicial machinery of the oxchequer. In fact the roording of the record is ouch that vo might asoumo that ho had reducod the barons to asoistanto in a court presided over by himsolf, ${ }^{2}$ and it quite possible thet by 1540 ouch a devolopment had come about. If thio nas so, it is certain that the offico did not justify or maintain so exaltod a position, and that Cromell was here using his poreonal standing as lord privy soal. Another case, concerning a country rector fined for non-residence, shows him acting together with the lord treasurer. 3 There cannot be eny doubt, then, that he somotimea sat in the oxchoquer court and that he did not confine himself there to his supposod dutios of goaling writs but took a leading part in the bueiness of the court. On the othor hand, his activity thore ras not a comon thing, and it is unlikely, in any caoo, that he could have at tended frequently.

1. 2 Uay 1533. P.R.O. $: 159 / 312$, Comunia, Eastor Torm, Recorde, mon.28-28d.

2. P.R.0. E 159/315, Comunia, Easter Term, Rocorda, m.1. Part of the case is annotated: "Parcatur por mandatom Domini Crortrell \& Baronibus prosentibus hic xxriljo Ianuarij $A^{0} \times x x j 0^{\circ} "$

3. Ibid. 317, Comrunia, Trinity Torm, Rocorda, m.15: "Parcatur per mandatur Theaburarij Anglio \& Domini Cromsroll ad instanciam Gosneld'." 
Ho had othor cello on hio timo.

There wao, howevor, one othor occaojon for which ho oparod time to be in court, namoly the admission of nor officialo. He was thero, on 27 April 1534, when Thomas Nalsh ras made fourth baron, and the day aftor when Humphrey Bowland appoarod to fill the now vacant post of king's remombrancor; though he ras in neither case the sole councillor presont ho alono is mentioned by name. 1 Ho was alono, hoveror, on 4 Lay 1535, whon his sorvant Richard Pollard was admettod to Bowland'g, office, vacant by ito holdor's doath. ${ }^{2}$ on 2 Docomber 1539 John and Clomont Smyth rore admitted to the offico of lord treasurer's romembrancer, "per Barones"; but they stroro their oath beforo Norfolk, as lord treasurer, and Cromell, as lord privy seal cind chancellor of the exchequer, 3 and the samo procedire. was observod with Nicholas Luke, the new third baron, on 14 April 1540, except that othero of tho council Fere aloo present to hear the oath. 4

This samo interest in the otaff of tho oxchoquor was ghom also in the caso of Nilliam Elys who was fourth baron at the time of Cromell'g rise to porrer. Elyo was a very

1. Ibid. 313, Communia, Eastor Term, Rocorda, m.26: "In proGoncia Egregij viri Thomo Cromeroll Armigori, Socretarij dicti domini Regio Ac Cancolarij huiuo Bceccarij, \& aliorum do Consilio dicti domini Rogio hic adtunc oxistonciur." 2. Ibid. 314, Communia, Eastor Torm, Rocorde, m.4. 3. Ibid. 318, Commia, Lichaolmas Torm, Rocorda, m.60. 4. Ibid. 319, Commia, Easter Term, Recorda, m.4. 
old man, over eighty, with long servico to hio crodit; and dooirous, as he told Cromoll, to dio in harnoss. ${ }^{1}$ Cromwoll, howover, appears to have held different vioms about important officials who were too old snd ill to attond to thoir dutios, as Elys evidently was, despite his rather pathetic asoertions to the contrary. He thereforo asked tho old man to surronder his patent of office, \& recuest not by Elye rith the counterrecuest that he right be allored to carry on for a yoar or two. ${ }^{2}$ Cromell retorted by sending his servant John Gostwick to collect the desired resignation, but all he got out of Elyo was another lettor about his ago, service, and continued suitability. 3 It is a nice point whother Cromroll's persistenco rould in the end have conquered the old man's obstinacy, but soon aftervards Elyo solved the problem by dying - in office, as he had deoired - and Thomas Taleh was appointed in hio place.4 The affair showed that Cromell was determined to have an efficiently rorking exchequer, for which roason he ras caroful to have the right men appointed and to attend their admission to office. Although ho dealt With Elys as the king's minister rathor than as chancellor of the exchequer, we have hore another pointe to the reason

1. L.P. $\nabla i .1308$.

2. Ibid. 1485.

3. L.P. Vii.34. About the same time, horrovor, Elyo vrote another letter in which he admitted that disease prevented his doing hig duty in the exchequer (ibid. 35 ).

4. Ibid. $589(10)$. 
Thy he became chancollor at all. It was part of a plan for controlling the financial edminiatration.

His correopondenco offers further exampleo of the importance the office had for hit. In 1533 Edward Loe, archbiohop of York, was in trouble with the exchequer about some money due before his appointment to tho soo which ho rofused to pay. Ho appoaled to Crompoll who, Leo said, had ordorod tho barone not to issue process ageinst the archbiahop; nevorthelese the oheriff attempted to secure payment, alleging that Cromell had comanded the money to be zerifed. Leo therefore pointed out that Cromell had now a place of guthority in the exchequer and could rrell see to it that such unjust clalms wore not prossod. ${ }^{1}$ Loe, at any rato, ascribed a standing to the chancellorship as oxerciood by Cromell which rould enable hiv to enforce orders on the barons which ho had isoued unsuccesfully before his appointment.

To quote some more examples. The sherifl of Corntrall, eddresaing his letter to Cromell as chancellor of the exchequer, begged to be excused from attending the court and promised to send the money of hio sheriffuick by his attorney there..$^{2}$ A potition, also addressed to him in that capacity, asked for the restoration of a horse which Cromell's oervant sifyt had orongly detained. The petitioner lost it at

1. L.P. Vi.1158,1219.

2. Ibia. 1309. 
Hacknoy, aftermards rocogniood it and clainod it as his omn in Smithpield markot, and thon brought an action in tho Guildhall. Swylt succoeded in havine tho ouit romorod into tho oxchoquor, before the chiof baron and Cromoll. 1 Here mo havo anothor instance of cromirell actually oitting in tho court. It is possiblo that at this oarly stago of hio caroor ho sat thoro with sone regularity, and that the memorande rolls concoal the actual constitution of the court by the use of a traditional forsule which inplios that all cases more hoard by the barons only. A hint like that containod in thio petition makes one suspect somothing of the kind, but nothing can bo proved. In these earlier yoars he cortainly attonded to exchequer business more freruentiy than later. Thus a letter, again addresoing him as chancoilor, informod hin of Lrauds conmitted in connection with a rardship; a man against whom a scire facias ras out for the colloction of a debt askod for the judgment to bo doforrod until after Easter, by which time he rould havo rocovored hio hoalth so far as to be ablo to como up and arrange the watter with Cromroll and tho undertroasurer; 3 the mayor of Southampton thenked him for his reasourance about an old fine in the oxchequer hanging over the borough, but had to add that Cromell's ordors did not soom to have prevonted attachmonte issuing out of the 
oxchoguer agningt somo ox-sheriffo. ${ }^{1}$ These activitioo ouggeat that Cromell had to rely on his chancollorahip at a timo when he was not yot strong onough to inposo his will on tho oxchonuer from the outgide. Io thue had his good roasons for acquiring on office thi rin juve him omo atnnting in the oxchequer and enabled him to ox rcire oud control ovor that repartment. Clearly, he oxploited it for rathor more than it was rorth. Refising to be tied by tho ireditions of $n$ anor office, he extended to scono to fit his ambitions and dosigns.

In choosing the chancollorship of the oxchenuer as tho office through which the exchecuer could be controlled, Erom-oli anticipated the future. The value of the office rose to $\$ 113.6 .8$ a year by Elizabetin's time, so that the chancollor then dron the third highest foe in the exchoquor, after the lord treasurer and the undertreasurer rhose salarios had remained practically unchanged. 2 This enormous increaso, amounting to an adniniatrative revolution rhich foreshadored the future greatnoss of the chancollor, was mainly due to the exchonuer roforms of Lary's reign which had throrn wuch additional business on the chancellor. It way, horrever, be asked why the chancellor should have boen pickod to do the ner rork. Tho anstrer rould sools to bo that his was an 
offico of small doscribod scopo but with largo inhoront poseibilitios of expanoion, a lact fully ronlifod by cromiroll and firot oxploitod by hiw. It could not foll to gain in stonding from the fact that he hold it. By uning the office to control the exchenuer ho had set a precedent which ras follored by tho later relormoro, Finchostor and Burloligh. Baker had not followed Cromiroll in vialbly asoorting the authority of the chancellor by sitting on the sirst bonch on the right of the lord treasurer, but the examplo ras not forgotton. It Wag taken up by sir Nalter vildmay who held the office from 1565 to 1589 and succoodor in having it rocognisod as ono of the important posts in the exchoquer. ${ }^{1}$ It vas reserved to the chancellore of James I, lod by Sir Julius Caosar, to complote tho nork started by Cromell, and to make the chancellor of the exchequer a leading officor of steto. All this is not to say that Cromell set out consciously to add stature to the office as an office. He ras intorested in it only inasmuch as it gave his accoso to the exchoquer, but a man of his porers and position could not hold any poot without in some measure increasing its importance and sotting procedents for its futuro placo in the adminictrativo machine.

1. Cf. D.H.B., xiii.375a. 


\section{PrincipaI Socratary.}

It was during its tenuro by Thomas Crommoll that tho office of tho king's principal socretary bocamo "tho binding forco of the atate, holding togother all the various unito of adminiatration". 1 Ho ras the first groat "modorn" aocrotary. Tho office was still so ill-dofined, so mach a porsonal office in the king's housohold, that appointmont was by rord of moith and delivery of the signet only. In connequence tro havo no evidence of the exact date on which Cromell was appointod, though wo can put it within fairly norror limits. Gardinor, the eirst secretary regularly to counteroign signot warrants, 2 oigned his last ourviving tarrant on 3 Fobruary 1534,3 and tho first warrant signod by Cromoll is datod 15 April 1534.4 Tho office, therofore, changed hands some time betwoen these tro datos. In all probability tho date traditionally assigned (April 1534) is correct as it is supported by a statement made on the 15th of that month that Gardiner had loot tho oecretaryohip. 5

1. F.G.Evgns, Principal Secretary, p.31.

2. The warrants preservod for hin secrotaryship are so oigned (P.R.0. PSO $2 / 4$, files for 22 and 23 Honry VIII).

3. P.R.0. C 82/679, no.4. 4. Ibid. 681, no.26.

5. L.P. vii.483. In vior of all this ovidence, no importanco can be ascribed to the fact that warrants to cromroll do not addrose him as socretary until lator. A warrant of 27 May 1534 (P.R.0. E 101/421/6, no.37) callo his master of the jorrolo only. It io in the higheot degreo unlikely that Cromer should have actod and beon addrossod as oocrotary for two months before the appointment took effect. 
On tho other hand, there is cloar ovidonce that Cromell ras acting as socrotary in the last montho of 1533. On 30 Soptomber, Thomas Derby, one of the clorka of tho olgnot, Wroto a lotter in which ho collod Crowsoll his mator and referred to a warrant which ho vas fomarding to his or his servants Richard Cromell and Ralph Sadlor to bo soalod with the signet. 1 In Decombor of the same yoar Cromoll deliverod to Lord Lislo's agent a bill aignod by the king, enother duty which properly bolongod to tho secretary. 2 The agent, Leonard Smyth, had asked Cromell to lot tho liconco in quostion poss without on:" loes boing paid, "but sucho comandoment ho said lay not in hym; notwithstonding, bicauso tho oignett is in his keping, now in the absons of tho socretary, Raufe sadeleffrold tako nothing for tho signett". 3 Tho socretary, Gardinar, was away from England from 3 Soptomber until the ond of the year; ${ }^{4}$ in his aboenco, Cromoll apparently acted for him, though ho did.not fool that as a tomporary socrotary he could authorise the remisoion of a customary foo due to the clerk sealing the bill. Hotrover, deopito Cromwoll's roluctance, Sadier, into whose pockot tho monoy would apparently have gone, took the authorisation upon himself.

1. P.R.0. SP $1 / 79,1.114$ (L,P. Vi.1177);

2. P.R.0. SP $3 / 7$, art. 120 (L.P. Add.886).

3. By putting another comma aftor "Sadelor" L.P. Add.886 makea nonsenso of the letter. Sadier 78 not, of course, to be described as secrotary (of stato) in 1533.

4. D.H.B., Vii.860b. 
It therefore appoaro that Cromoll had givon tho signot, which ras naturally ontrueted to his custody rhile anrdinor was array, into the tomporary keoping of sadior who was hio privato clork. This also explaine why Dorby ohould havo oxpectod sadier to bo in a position to goal a signet rarrant. During this ohort poriod whon he actod as Gardinor'o doputy Cromell geoms to have exployed his privato staff to do the work of the signot, a fact which oupports the conclusion that he was not yot actually aocretary. Ho was appointod oomo four months after Gardiner's return. Te shall not go far wrong if ro suppose him to have had an oyo on the offico for somo time, though he had to rait until April 1534 belore he could finally oust Gardiner from it and thus mark his victory in the king'a counsels over ali rivals.

The date on which Cromell relinquighod the office is also not quite certain. He continued to hold it after his promotion to the keepership of the privy oeal, for he is oeveral times given the tro titles together. ${ }^{1}$ Horrover, sorse months before his fall he ras succeoded by Thomas Hriothesley and Ralph Sadier as joint secretaries. The warrant appointing ther is undatod, ${ }^{2}$ but it has usually boon put into April 1540. They pere first named officially as secretarios on the occasion of Cromplit's creation as oarl of Essex on

1. LeP. Xi1.I.1098; xii.II.445.

2. L.P. X $x \nabla .437$. 
18 April 1540, 1 and Triothosley's cousin, the chronicler, spocifically mentions April in his noto of the oront. 2 Novertholess this ovidenco might be conoiderod doubtful onough not to proclude an earlier surrendor of tho socrotaryohip by Cromoll, woro it not for tho facto that Wriothosloy oignod hio namo as a clerk on a writ of privy oonl as lato as 30 Larch 1540,3 and sadlor'o regigtor of the signot bogan on 1 April 1540.4 It may therefore be considorod certain that Cromell continuod as principal secrotary until April 1540, his ouccessors probably taking ovor on the first day of that month.

Grost uncertainty prevails about tho emolumente of the office at the time of Cromell's tenuro of it. The only piece of evidence which wo pos8ess is an item in ono of CromFoll's private accounto which givos the profito of tho oignet $88994.0 .81 / 2.5$ This account covers the period from llichaelmas 1533 to Lichaelnas 1535, or about a year and a half of Cromell's socretaryohip. Tho accountant, howover, noted that ho had recoived the money from another of Cromioll's servants, so that it wust be doubtful whother the 294 constituted the rholo income from the signet for that poriod. The

1. Ibid. 541 .

2. Friotheoley, Chronicle, (Camden Society), i.115.

3. P.R.0.C $82 / 764$, no.77.

4. B.H. Add.2us 35818.

5. L.P. ix. 478 . 
silence of the othor surviving accounts makes it not unlikoly that some other momber of Cromrell's stese, whono accounts do not survive, adminintered Cromoll's incomo as nocretary. That there wos ruch an income in proved oven by this solitary item which also shors that it ras derived from the foos paid into the signet office. Te knor that later these foos rore sharod betrioon the secrotary anc tine clerks, and it is probable that a similar procedure was normal in Crodtrell's timo. The gocretary shared tho sogling but not the oriting foes of the signot, for he controlled the seal but did no part of the labour of making out documents. ${ }^{1}$ inother there vas any income apart from those lees re connot teil. Thero appears to have boon no oalary or annuity. Under slizabeth tho two principal secrotaries drom 2200 , presumebly betweon thom, ${ }^{2}$ but is has proved impossible to trace any such salary to tho reign of lienry VII. It might be permissible to take the risky step of arguing back from Elizaboth's reign, but tho silence of Cromell's eccounts, which are otherrice so informative on his salsries, mact nake us doubly caroful. The warrant appointing Crantrell'E, guccossors fipeake of such "ffoes Droicton Dieutics and comodities...as hauo doo or ought to belong to tholfice of his Laicsties principal soc-

1. F.G.Evans, Principal Sccrotary, pp.2061.

2. Ibid., p.352. 
rotaryo". 1 Thio agein ouggoste cesual foos rathor than a fixod salary. It rould secm, theraforo, that in Cromsell's, time tho socretary rocolvod no money excopt hin sharo of the sealing foos, a share which way have amountod to a rough average of $\$ 60$ a year, though tho evidenco for this figuro is slonder and probably unreliable.

In addition, the secretary ras ontitled to cortain benofite attendant upon his porition in the housohold. The Darrent just quoted alno apnointed to the secrotarion a lodging in court, rith "lyke bouge of courte in al thynges 0.8 is appointed to the secretarye". Ey the torms of the Eltham Ordinances this ras rorth 222.7 .11 e yoar. ${ }^{2}$ Thus ve may conclude that the oecretaryship was poosibiy vorth to Cromell somothing liko $\$ 100$ a year, certainly a small oum when his position in the government is compared with that of the lordo chancellor, treagurer, and privy seal, elt of thom nere vastly better rewunerated.

But if the office was not unduly lucrative, nor, as a matter of fact, one of great social distinction, it offored

1. P.R.0. SP 1/158, 1.153 (L.P. XV.437).

2. Household Ordinancen, (Soc. of Ant.), pp.162f. This ras increesod some time ofter 1540 to $\$ 33.19 .1$ (ibid., p.210). In addition there appoars a groat oum for diets: two moseo, each rorth $\$ 06 \mathrm{p}$.a. Toro to be served to the socrotaries, a term which ircluded the French and Latin as roll as tho principal secretaries, and very probably thoir staff as tall (ibid., p.192). This ontry must be dated after 1540 as tho lord groat rester is contioned. 
an imsense ocopo. Invostigationa of tho socrotary'o oarlior history have shorn hir as an officiel in the royal hourohold, auporintending the king's personal correopondonco and onjoying his closest confidonco. 1 Particularly, he ras orployod in diplomatic missiono, e.part from his dutioo as custodian of the gignet and hoed of its clorical orgrnisation. 2 Horrovor, thore ras no patont to circumscribe his dutios, and hordly oven a customary ophere to which he tas bound to fool rootricted. The vast expansion of the gecretaryship is a commonplace of the administrative hiatory of the oixteenth and oovonteenth centurios. This expansion goeg back no further than Thomas Cromoll. Fe have boen told that it was ho who, by the force of his personality, "brought tho office of King's oecretary into a pooition of exinence entirely nor to it". 3 When he took tine secretaryohip it ras an important housohold office, but it had hardly begun to be an office of stato. His imodiate predecessor, Gardiner bishop of winchestor, Too probably the most eminont wan who to that date had held the office. Let to him it meant little more than it had done to othors for some fifty yoars beforo, cortainly since Edward IV's oecrotary William Hatclyffo. It put him noar the king and gavo him the king's confidence: in January 1532

1. J.0tray-Ruthren, King'g Socretary, pp.62ff.

2. Lra.Higham (P.G.Evang), "liote on the Pro-Tudor Secretary," Egsays...pregentod to T. F. Tout, $\mathrm{pD} .36111$.

3. Ibid., 0.361 . 
Cromoll wrote to him of the king's complaint that tho nocrotary's absenco meant the absence of "my right hand". 1 But out of a total tonure of offico arounting to lesa than five ycars derdiner spont oix monthe abroad on embasalos. ${ }^{2}$ Ho clearly did not think homo affairs, the control of ovory aspect of the administrative machinery, a part of hie dution. It was this control which Cromell ras to achiovo through tho principal secretaryohip. For at loagt a year before Gardinor surrendered the office coomell was known to be the king'g chief minister. Gardiner tus one of a number of leading councillors, but in his capacity so socrotary ho confined himoeif to tho traditional dutios of taking charge of the king's correspondonce, controlling the signet office, and engaging in diplomatic nogotiations. Cromroll did all theso thinge, but ho addod 80 greatly to the rork of the gecrotary that he virtually crekted a ner office.

That did Cromell do as occrotary? To leave his activities as head of the signot clerks to be discusood in another place; ${ }^{3}$ oufice it here to say that he certainly carried out those duties to the full. The significant point is that there is not an aspect of the government of England which is not to

1. L.P. V.723.

2. Gardiner 7as secrotary Irow July 1529 (L.P. iv.5798) until liarch-April 1534. He was out of England from December 1531 to larch 1532 and from Soptember 1533 to the end of that yoar (D.N.B., vii.860a-b).

3. C1. belor, chapter 4, Sectiono I and III. 
bo found in the correspondenco of tho king's principal socretary Irom 1534 onfarda. In 1592 Robort Boale, Faloingham'a chief clerk, "rote a "Treatige on the offico of a Councollor and Principel Socrotario to her Lajostio", 1 in which ho onumerated the basinese which lay within the socrotary's ophere of duty. It included all mattern concorning roligion, control over the councile establiohod in tho borders of the roalm, the defence of the kingdom by land and oea, the affairo of the king'o dominiono boyond the sea (Ireland and the Channol Islands: in Cromtrell's time we ohould have to add Calata), Englioh merchante abroad, the royal rovenues and finances in general, the royal household, foroign affairo and intelligence. A comprohenalve catalogue indeod, but no moro comprehongive than a list of Cromell'g activitios which could easily be compiled frow his memorande and correspondence. In cortain respocts Crowmell did nore than wost Elizabothan secretaries rould have thought their office justifiod; thus he superviged both roligious affairs and finances more closely and completely than any oingle man oror did again, with tho possible excoption of Burghley. On the rholo, hotrovor, it can bo said that the ophere of activitioo which Cromoll establiohed for himgelf had sixty years later become the norm for the secretaryship. Ho had mado the office into somothing

1. Printed by-Prof. Conyers Read as an appondix to his $\mathrm{Mr}$ Secretery Maloingham, i.42311. 
that can only bo doocribod as a prowiorohip; ho had la1d a foundation and orectod a ocaffolding which tho Cocila and Taloingham could oasily uno in building tho finighod structuro.

One point dooorvos spocial notico. A caro has boon made out for supponing thet the socretary's groatnose restod primarily on his knowlodge and conduct of foroign arfairg. 1 Crommell took his ohare of controlling foreign alfairg, 2 but Thile in this respect ho may have onlargod and improved ho did not innorato. Foraign affaira had boon tho usual, almost the netural, fiold for men trained in correspondonce and languages and possersod of the soveroign's imediate confidonco. Crompll'a great addition to the scopo of the office ras gorormment at home. He made the secrotary supromo in the intornal adminiotration of the state. Judging only from tho things which ho did or supervised, wo might roll be tomptod to call him the king'e sole executive winister. Nas thero any nood for any other winister, for anyono olse concorned with both the making of policy and the rorking of the adminigtration, whon one man took charge of finance, the civil service, polico, cconomic policy and administration, tho control of parliamont and council, the preparation and carrying

1. Higham, "Note on the Pre-Tudor Socretary," Esaaye...presented to T.F.Tout, p.366: "Loro and moro tho secretary controlled tho rarious threado of diplomatic intercourso, continually incroasing his porror in council by his knorlodgo of foroign negotiations."

2. Lorriman, i, chap.12. 
out of logiolation, the occlosiagtical affairg of the ago of tho Reformation, and foroign affaira? Thoro voro, in fact, other ministers, memboro of the innor council like liorfolk, or hoada of departmento liko Paulot, mastor of tho rardo, or Richo, chancoilor of augmantations, but thoy wore one and all under the supervision and authority of Cromell as secrotary and lator as lord privy ooal. Cromoll wao a primo ministor who kept a strict control over his asoociatos and subordinatos, and who in addition attendod to much businoss in tho smallest dotail.

It rould not, of course, be true to say that a aimilar preominence in the king's governwent had nover boen knom. From tho Angovin juoticiars onvardo thoro roro officos under tho crown which offered the widest scopo to their holdoro. By tho ond of the fifteonth contury ono officor of otato had emerged as the head of the official hierarchy. Tho chancellor had reached a position of eminence which he ras to prosorve, in theory at any rate, until the prosont day. Folsoy had used that offico to make himself supromo in a ray which was not so very different frow Crowoll's oupremacy, howover much thoir tasko, attitudos, and activities may have difforod: To may therefore ask why Cromicll did not take this office, with all the prostige and porer which traditionally belonged to it, but preforred the comparativo obscurity of tho occrotaryship 
Which only his c:ploitation medo so isportant. His eroodom of choice is indicated by the fact that contemporrories somotikeg thought he mi.jht jet trico the first office of atroto, and a rmour to the effcet circulated as lato as :ovonbor 1535 then Chapuys roported that Cromiell :ould not hitiorto accept the chanceliorripip but that it ing thought he rould coon ellow hinsolf to be persuadod. 1 iothinis caico of thio, but it is clear that crormoll quito deliberotely rojectod thir promotion wici others rished to press upon him. Tho enrror is partly, no doubt, to be found in the fact that Wolsey'g fato was no oncouragoment to follow in Wolsoy's footsteps, and it is also true that comparative ohocurity probably ouited Cromell's character rathor bettor than tho pomp and circumatanco of an anciont offico.

Howovor, there jere more cozent reasons. For one thing, the chancelior had become so burdened with routine dutios those of a judge - that it 1 as incroasingly difficult for him to be also in administrator and controllor of policy. Fology binself had groatly increasod his judicial rork by expanding the court of atar chambor, and even ho had found it hard to combine the tro aspects of the office.2 The timo ras rapialy approaching whon the lord chancellor rould be above all olse tho bead of the judicial machinory of the realm. Jolsey's 
succossor, 3ir Thomas lforo, wao much hrppior in that phoro than in thrs of politicn, and ho not tho tono for those iho colvo netor him. 1 Furthermoro, and orising from this fact, tho chencoliorship as an offico of steto did not ronlly snstror tho purpose which Cromoll had in mind. Evon its administrativo dutios rere circumsibod end definod. Folsey had usod it rainly to make himsolf a judgo and a foroign ministor. Cromell'g ohoice of offices ghows that he had only tho omalloot intorcot in boing the former, and 8 vory secondary in being the lattor. Abovo all ho mishod to govern England, and ho knoit that tho first condition for such a govornmont ras control of the financial adriniatration. This the chancollorahip did not offor. liaturaily, no man tho agpirod to be the king's chiof councillor could ignore foreign affairs and diplomacy. But ribile Tolsoy had built his powor on thooe and on the majesty of a judze and cardinal, alloring the adminiotrative machino largely to man itsolf undor tho impotus givon to it by Honry VII's roformo, Cromrell dosirod to orect his porrer on a foundation of adminiatrative control in ald ito dotailo. He mas nover a judgo, and the day-to-day conduct of judiciel affairs is the ono largo itom significantly absont fros a catiloguo of his activitics.2 The position to

1. After Nolooy only one chancell or triod to frec himself from aome of hio judicial dutice in ordor to havo timo for politics. That ras Friothesloy, and ho failod (ibid.).

2. This otatomont is not invalidatod by tho part ho played in 
Which be aspired ras in a nonso a nor ono, for in 1530 goneral control of the adminintration rostod with no single perron except the king. He thercforo choso an office which wao notr to the highest honours in which to ombody thin porition. The reign of Honry VIII marks a transition in the fiold of minioterial proominonce with a otartling directnoso vory different from the usual evolutionary obscurity of these things. The last modieval chancellor rao folloried by the first modern secretary of state. 1

A rord seeva necessary on the quostion hor far cromroll was afreo agent in choosing his officos. Aftor all, it may be said that the chancollorship ras in Audoloy's hands and Cromell could not have taken it ovon if ho had rantod to. To this it must be answered that poople at the timo thought that be could. As for tho secrotaryship, vie saip that Cromreli undertook its duties at the first opportunity, even while it was yot in another's hand. That ho deliberately ousted Gardiner froi: a position rhich implied the king's special confidence is indicated by his first docuring Gardiner's removal on embassy to France, and by tho fact that Gardiner's loss of the socretaryohip coincided fith his

political trials and investigations, or by the many potitions for redress of grievencoo which nere addressed to him as thoy were to any other loading councillor.

1. Though Cromroll is never callod oocretary of stato, 70 may here employ a slight anachronism in ordor to make plain That his "chief oecrotaryahip" amounted to. 
tomporary banishment from court. 1 Tho acquisition of the office marked Cromell's victory ovor his chiof rival, and thore cannot be much doubt that ho doliboratoly pickod tho office for the purpose of making himsolf supromo. It may also bo rewarkod in gonoral that a study of tho timo makos It clear that whore detailo of tho adminiotration froro concernod tho king did not intorfore. Unlose, thoroforo, thoro is dofinito ovidenco to the contrary, :o may tako it that Cromell held a particular office bocause ho ranted it, and not bocause the king wantod him to hoid it.

It has ofton boon noted that the riso of the oecrotaryonip can be moasured by the act of 1539 which appointed tho order of sitting in the bouse of lordo. 2 The chief socrotary is thore mentioned as ono of the great officers of otate, following the lords chancollor, treagurer, president of the council, privy seal, groat chaiberlain, conotable, marshal, adniral, grand mastor or stemard of the housohold, and king's chamberlain. This mas promotion indood for an officer whom Eltham Ordinances of 1526 had placed in tise fourth group of those ribo rere entitled to "bouche of court", on a lovel with the vice-chamberlains of the housohold. 3 In 1526 tho secretary had clearly atill beon a household official; ${ }^{4}$ by 1539

1. L.P. viil. 441 .

2. 31 Henry VIII c.10. 3. Household Ordinance日, (Boc. of Ant.), pp.162f; Tho lord
4rivy soal ras placod two ranks higher (ibid.).
4. F.G.Evans, Princinal secretary, p.29. 
ho had become an officor of otato. Hig importance vas now Euch that if ho ras a baron or a biahop ho ras to tako procodence over all othor barons and biahopa, and if a comoner he rag to alt in tho house of lordg with the othor miniatora of otato. The most significant aspoct of tho aot is that it ras not parood specifically to oxalt Cromroll. Not only would he have takon his place 0.0 lord privy goal but ho 18 actually mentioned by name as the king'a vicegerent in apirituals, and as such ho 70 s to tako procodonco of all othor members of the house, even the archbighop of Cantorbury. lioverthelose the oecretary ras included in the tormo of tho act. It was not a question of doing romothing for Cromoll, but of marking tho height to which ho had raisod tho office of principal secretary which firot gavo hit a visiblo position of preeminence in the govornmont. The historian of the Tudor and stuart gecretaries hag oummod up Cromwell'g now oecretaryship as "not weroly eithor the king's privato servant or an administrative officigl, but a minister of tho crown with definite political viers, representing one among many factions betwoen which the crom had to choose". 1

Though this was the kind of secretaryahip which ho had

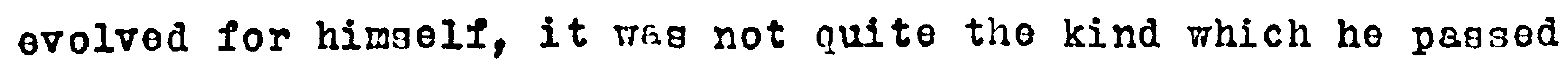
on to his successors. He raiged the oecrotary to a high 
advisory and oxecutivo position, but oven ho himsolf found It nocessary to attain to a higher dignity whon ho was croatod a poer. The titlo of "magtor secretary" pro good enough only because of what its holder had put into tho offico, and tho higher office and botter title of lord privy seal became doGirable when master Crowoll bocamo baron Cromell of Iimbledon. Novertholoss ho held both officen together for noarly four yearo. Perhape he did not rant to lose the profits of the secrotaryohip; porhaps, again, ho loarod to put a poseiblo rival in tho pleaco which had mado him great. At any rate, when ho decided, or perhape was forced during tho upo and downs of the last monthe of his minigtry, to give up tho secretaryship, he curtailed its scope, powers, and newly-mon dignity ouite sererely. The appointment of t7o secrotarieo, oqual in porror and apparently doaling with the same fiold of administration and policy, scotched any possibility thero might have boon of a principal secretary rivaliing the lord prity soal. Friothesley and Sadier more to be Crommoll's subordinates who were to take a good deal of the routine of government off his shouldors. It may woll be aoked thy Cromell suddenly docided to shod part of tho burden which he had carried successfully for so long. The most probablg answor rould soom to bo that the appointmont, under himsolf, of tro of his wost ablo and tmastod lioutenants ras moant 
to strongthon his position within the council in the quarrol With tho Gardinor-Norfolk party mhich ras roaching ito hoight in April 1540, though othor oxplanationn aro posoiblo. 1

Thatovor the roason, appointod thoy woro, but thoy woro not to be second Cromirolla.2 Thoy rore oach to havo a aignot and to keep a book of what paosed throu in their hands, but both rere to know both sidos and to pool thoir foos. Tho office continued 8 one exercised jointly by two holdors, oithor becauso they rore to propide a chock or cach other, or (which re think moro likely) bocauso the office ras to run omoothly evon when Cromoll docided to uso either Nriothosloy or Sadior for apocial purposes. Thoy wore to got all tho profits incident to the offico. Paragrapli four of the instructions shors clearly for rhooc benofit thoy rore appointed: "...al suche tymes ao the Lorde Pryvo coalo ohalbe present in the Courte" they "shall accompany him at his tablo". They rere not to hold the exalted rank givon to tho oocretaryship by the act of 1539, but roro to toko precodenco aftor all peers opiritual and tomporal and aloo after the lour chiel exocutive officoro of the housohold - tho treasuror, controller, master of the horoe, and vice-chamberlain. This

1. Cl. bolow, pp. $353 \mathrm{ff}$.

2. The warrant of appointwent is extractod in L.P. $x \nabla .437$. The original (P.R.0. SP 1/158, 1f.153-4) is printod in State Panorg, Henry VIII, $1.623 ;$ a olightly different later cony (B.M. Stotro IIS 163, 1.170 ) is printed by Evano (Principal secretary, pp.3601.). 
Was a distinct dornwatd otop for tho oocrotaryohip. Cromoll prosumably intended that an offico which might posolbly bo dangerous to his orn position should be cropped, and yot that trusty sorvante should be promoted to a placo whero thoy might be of uso to him in tho council. He cortainly intendod to keop them under his orm control.

Horevor, in the lost resort those messures of dombrading the secrotaryship rere tho result of Cromsoll's opm higher position as lord privy seal, and of the party struggles frich procedod his fall. Crowwell's main influence on the socrotaryship $\pi$ rero those outlined bolore. He creatod, the modorn oecrotaryohip and gavo ito holder tho character of a miniator of state rho, if ho righed, could put himself in the centro of the government. He fashioned the instrument which the Elizabethan secretaries took over end improvod, though nono of thom ovor commandod 80 all-ombracing a oupromacy bocauso none of thom combined 80 many offices in the tomporal and opiritual epheres. Control of diplomacy and eron of the king's coungils had beon inherent in the pre-Cromrollian oecretaryship and were morely brought to greater Iruition by hio personality. He did something new and unprocedented when ho turned the secretaryohip into tho agency which co-ordinated tho whole of the administration; making it thus the chief oxecutive ministry under tho crown. 
V. Magter of the Ro11日.

About Lay 1834 the master of the rolln, John Taylor LL.D., an old chancery offlcial and once clork of parliament, ras reported to be on the point of rosigning his office. Cromwell had publicly mentioned as his ouccessor a master in chancery and one of the leading civilians of the day, Dr. John Tregonmell. Howover, nor that the matter became critical Tregonvell soemed to gron a littlo doubtful of his hopes and vrote to Cromioll in order to remind him of his provious promiseo. ${ }^{1}$ His doubto wero juotifiod, for when Taylor actually rosigned later in the year cromrell took the office himsela. 2 The date of his patent was 8 0ctober 1534,3 but he ras reported in office a fortnight earlior, ${ }^{4}$ and the chronicler Friothesloy says that he ras made waster of the rolls in the beginning of the uichaelmas torm and took his oath in the chancery of the first day, that is on 6 0ctober. 5 Another tradition nas thus overthrorm, and the second office in the chancery also went to a layman, an innoration upheld by Cromsell'o immodiate successore. Crommoll laid down the office ooon after he

1. L.P. Vii.743.

2. Cromell's patont declared that the offico ras racant "per suroum reddicionom litoramen nostrarum patencium per nog dilecto nobis Ioheni Tegler Clerico" (P.R.0. C 82/689/2). 3. L.P. Vi1.1352(3).

4. IbId. 1182, John Huseo to Lord Lisle on 23 Soptember: "Eromvell is nor Haster of the Rolla."

5. Friothesley, Chrontlie, i.26. For the date cl. Chenoy, Handbook of Dates, pp.67,70. 
bocame lord privy ooal, boing auccooded by the attornoy-gonoral, sir Christophor Halog, on $10 \mathrm{July} 1536 .^{1}$

The masterahip of the rolla ras one of tho most lucrativo offices which Cromoll over hold. In tho firot year (1534-5) ho rocoived from it $\$ 291.4 .101 / 2.2$ The poriod from alchaolmas 1535 to 12 duly 1536, whon he coobod to bold tho offlco, yiolded him $£ 317.13 .101 / 2 .^{3}$ Theso oumg more medo up, as Cromell's accounts shor, first of all from the foos duo to the master of the rollo for every patont oritten. In tho first yoar ho had 104 from the clorks of the potty bag and $\$ 35$ Irom the six clerko, and in the last nino montho 167 and t30 rospectively from tho oamo sources. He mas alao ontitlod to 28. Lor every patent sealed, 4 and entries under thet hoad are duly noted a being paid by the undorclerk of the hanaper. Further he recoived "casualtieg" from tho cursitors, that is, fines on documents prepared by thom. He had 8 out of the hanaper for his winter and summer robes, 44 from the chiel butler of England for a tun of wino traditionally his duo, a owall traditional Chriotwas gift from the prior of the knighto of st. John, the rent of tho London as8ize court, and - very

1. L.P. xi.202(17).

2. P.R.0. SP 1/105, İ.24-5 (L.P. xi.66[i]). The oame period yiolded 8284.1 .6 by another account (L.P. ix.478). Tho differonce is probably due to oeveral itomo lioted in the later account not having cowe in in time for the earlier.

3. P.R.0. SP 1/105, If.26-8 (L.P. Xi.66[ii]); or \&310.17.0 by another account (L,P. Xi.135).

4. Maxmoll Lyto, Groat Seal, p.333. 
mach a survival from oarlior timos - ton marko from tho abbot of Thame for a horse to carry tho king'o recordo. As tho rollo had long coesod to bo carriod about with tho court, thio was so much clear profit for tho master. As kooper of tho houso of converto, an offico combined with the materohip of the rolle gince 1377 at tho lateot, 1 ho 780 paid a regular annual allowance of $229.10 .21 / 2$ out of the hanapor, of which E13.6.8 were for himsolf while the regt went to tho other officials and tho inmates of the house. ${ }^{2}$ The incomo which Crommoll derived from the mastorahip of the rolls was thereLore considerablo, but it was nothing to what the mastor might expect soventy years later. 3 The groat exploitation of crom officos for privato gain had not yot begun.

There ras another matorial bonefit to be obtained from the office. The mastor of the rolls ras ontitled to an ofricial residence, the Rodlo House in Chancery Lane, on the site of the present Public Record 0ffice. Very ooon after

1. Ibid., p.11.

2. Thio oun appearo also in the hanapor accounto (o.g., P.R.0. E 101/222/11) and, as it ras chargod on tallios, in the oxchequer's declarations of the stato of the treasury. In 1536 the money was entered as allowed to Thomas Cromell, keeper of the hanapor, for payment to Thomas Cromroll, maotor of the rolls (P.R.0. E 169/69).

3. C1. Uasmoll Lyto, Groat Soal, App.B, pp.40911. In 1614 Sir Julius Caesar mas told to expoct a yearly income of 82380 Irom the mastership of the rollo. He found, howevor, that it docreased year by yoar Irom $\$ 2200$ to $\$ 1600$, but even that was otill vastly more than Crommoll'o prolito amountod to. 
Cromell became mastor hio lottero began to bo datod from "tho Rol1g". 1 Normally the rooldence wont with tho offlce, but Cromell'g lettors provo clearly that ho continuod in posooogion of "the Rollo" long aftor he had coaood to bo mastor. 2 Lotters mero addresoed to "tho Lord Privy Soal at the Rollo", and Cromwoll had his clotheo thore as lato as 1537.3 In vior of this it is hardy ourpriaing to hear that "sir Chriatopher Hales being Master of the Rorleo dinod aftor at the Kingeo Hoad taverno. Ho is reportod during hio tymo at the Rorles to have kept verye small house or none at all".4 The unfortuncte man wos being kept out of his official rogidence by the lord privy seal who treated the house ao his private property.

The duties and ocopo of the office rore basically the custody of the chancory rocords and of the houge of converto. Neither of these need dotain us for long. Tho mastor of the rolid was otill considerod poroonally ronpongible for the records; there survive orderg to Cromell's prodecessor and his successor to cancel recognisances or make alterations in documenta among tho recordo in his keoping. 5

1. Lorriman, if.279. The first ourviving lottor so dated is of 17 Octobor 1534.

2. Ibid., il.281. The last ourviving lottor so datod is of 19 January 1538.

3. L.P. xi.769-70; xii.I.669.

4. Sandors, Orderg in Chancory, $p .17$.

5. P.R.0. C 82/631/1, 635/10,650/5, 664/23, 768/35, 767/12. 
Ijo ouch ordoro to Crowoll aro oxtant, but wo wat novortheloso conclude that ho, too, exorcised at loast a thoorotical suporvioion. Tho keeper of the rocords in the Torror wao appointod by the master of the rolls, as roro the clerko of tho Rollo Chapol; ${ }^{1}$ if the mastor did not himoolf doal with the recordo, bo 780 in charge of the officors rho did. As for the houso of converto, thio contained during Cromell'o tcnure of offico one chaplain, tro clerks, and throe lomale converto. 2 With one official to every inmate, the adminiatrative dutieo faliing to the master's sharo must have boon negligiblo. At any rate, thero io no ovidence that Cromol + ovor bad to attond in person to oither of these aspects of hio offico.

Further, the mastor of the rolle, an the chiof of tho trelre mastors in chancery, 3 pas one of the officialo entitled to "rrite to the soal", that is to mite documents to which the groat seal 780 to bo affixed. Ever oince the rolgn of Edrard I it had boon chancery practice to frite the nerse of the officer primarily rosponsible for a document in tho lower right-hand margin; ${ }^{4}$ though originally the clerk who mrote the writ nay himself havo signed, thio was clearly not the practiee by cromell's time. His name appeared under a multitude

1. J.S. Filson, Lord Chancollor in tho esriy 17th Century, p.5. 2. CI. the accounts of the koopor, 0.8. P.R.0. E 101/254/5. 3. He was appointed 88 such by an order of tho timo of Honry $V$ (sanders, 0rders in Chancery, p.7b).

4. Lastroll Lyte, Groat Soal, p.26e. 
of documonte fosuing from the chancory, as le teotifiod by original letters patent, and by copies on the momoranda rollo and in precedent books. ${ }^{1}$ But the originalo ohor that tho narie ras appended by the writing clerk; thoro are no authontic signatures. Cromell's name on a docarsont doos not prove that Cromell had anything to do with the drafting, writing, or chocking. The reason why his nawe, or for that matter the names of othor masters of the rolle, appears with such Irequency is oupplied by the ovidenco of John Croke, master in chancery, who described the organisation of the chancory in $1554 .^{2}$

of the officiale entitled to write to the seal, Croke said that the oix clerke, the clerko of the potty bag, and the tro examiners wroto "in the liaster of the Rolle his name". In other porde, all documents rritten by then pould bear the name of the master of the rollo, and the master rould in the last resort be roaponsible for them. Thus the master of the rollo eupervised the groater part of the clerical side of chancery, the only clerks outidde hio imodiate control boing the clerk of the crom, the other wastere, and the curoitors. The clerk of the crown, according to Croke, wao reoponsible for "all oomisalons and proces of the Crome, and generally

1. E.g., P.R.O. C 193/2.

2. Sanders, Orders in Chancery, pp.1011. 
all procese8s that torrchoth oythor lifo or mombor". Tho other mastoro would thooretically bo ablo to writo tho samo kind of writs as tho mastor of the rolla, without oxerciaing his suporvigion of othor clerka, and somo of their namos occasionally appoar on a document. They vere, horrovor, uoually such loading civil laryoro a, for inotanco, doctoro Trogonwell and 0liver, and wore widely omployed in various capacitios by the government. They cannot, therofore, hevo attendod mach to thoir dutios in chancery, though it ohould bo notod that according to Croke they alono could make writs of gupergedeas. Ono of their number, tho prothonotary, was reoponoible for treaties and the like, as far as thoy vore viltten in chancery. The cursitors could only mite mito of courso, or otandardisod vrits whose issue roquirod no opocial authority. That loft all patento of granto and many writo to tho oix clerks and the potty bag who may bo describod as tho two fundamental oectiono of tho writing aide of chancory. 1 They composed the special dopartment of the mastor of tho rollo; not only did they "write in...his namo", but he also had tho eppointment of both groupa in his gift. 2

As master of the rolls, Cromell. in charge of those parto of the chancery machinery which kept

1. Croke gave a long list of writs affocting the judicial olde of tho chancery, "where the Mastor of tho Rolles hag a flee", Which rore regerved to the petty bag.

2. Stat. 14 \& 15 Honry VIII c.8; L.P. X11.II.638. 
ito rocords and issuod, among othor things, the loso atorootyped kindo of documonte. As tho chiof of tho mastora and gocond-in-command of the rhole of chancory, ho mut havo oxerciood a goneral control ovor tho whole of ito clerical organioation. In this rospoct, tho offico was of conoidorablo importance in the administration, for though the chancory was no longer the sole or even perhaps the moot important secretariat of the crom, it $n a g$ otill tho biggest. It handlod by far the groater part of the routine clorical rork which enabled the Eovernmont to bo carried on. Even if Cromell did not personally writo, chock, or "ply"1 chancory documento, ho was ag master of the rollo responsiblo for a great many of them, and rag altogether in chargo of the whole writing ofdo of chancery. On tho arailable evidenco it is imporeiblo to sey whether he personelly ever carried out the routine dutieo of the office, but perhaps it way be considered significant that he never appointed a deputy, as permitted by his patent, and that he relinquighed the office as soon as he became lord privy oeal. This was at a time when his otar was definitely in tho ascondant, 80 thet 70 cannot sook for tho roason in opposition from the king or court. Nor rould foar of

1. In May 1545 lord chancollor Friothesloy ordored "that no ordynarye procosoo do pasoo to the seale...but tho samo bo lirgt perused and plyed [loldod] by $80 m 0$ ono of the diriotors of Chauncery" (Sanders, Orderg in Chancory, p.8). Friothosley learned his businoss undor Cromtell; was he perhapo echoing a practico, or at loaot an intention, of his maotero'o? 
pluraliam explain it; ono moro offico mould hardly havo mado mach difference among 80 many. The mastership of the sollo cannot have boen congidered too lorily on pefico, for Cromroll continued to hold the ruch inferior offices of the jerrolo, the hanaper, and the chancollorohip of the exchoquer until his fall. It seeme more likely that the duties of the nor offico, involving as they did the supervision of yot another oecrotariat, and the mounting proscure of buginose that fell to the share of the king's chief rinister, forced him to surrender an office which can in that case have been no sinecuro.

Today horrever tre are inclined to think of the master of the rolls as primarily a judge. Did Cromroll act as one? The answer io complicated by the fact that Cromplil was a councillor and as such ondorrod with quasi-judicial functions; tho many appeals to hi's and his frequent arbitrations botreon contending parties are really to be ascribed to that oide of his official life. In March 1535, for instance, a number of wen zere said to be due to appear before him, eithor by hipsolf, or vith othors in the star chamber, or with the chancellor. ${ }^{1}$ The vory montion of the atar chamber indicateo that conciliar pororo are in question, and the fact that wost of the cases concerned troasonable utterances otrengthono that interpretation. Mbthout invegtigating all chancory procee-

1. L.P. Vii1. 457 . 
dingo for the rolovant tro yoars, a taok quito boyond tho acopo of the prosont atudy, it cannot bo claimod as fully provon that Cromwoli nover sat as a judge in chancery, oithor as the lord chancellor's doputy at Fostminstor or hoaring cager in the Rollo Chapol, an did tho wastor of tho rollo of the oarly ooventeonth century. ${ }^{1}$ During the roign of Honry VIII the master of the rolls ras jometimos called vicochancollor, the appellation being givon to Cromroll himself on one occasion, 2 and Nolsey bogan to delogato part of tho chencellor's judicial dutios to him. 3 inilo, horrover, knotr of comiasions to Cromrell's predocessor and to one of his succoseors to hear cases because the chancellor was too busy in other affairs, 4 there survives no such colimionion for Cromtroll. During his rulo the chancellor, Audeloy, confined himgelf to his judicial duties and needed no help. It is, moreover, clear that the real rise of the master of the rollo as a judge datos from tho early ooventeonth century, 5 whilo the theory that the mastor had no original authority of hio orn but acted only 88 the chancellor's doputy poroistod into

1. J.S.Mileon, Lord Chancollor in tho oarly 17th Century, p.6.

2. L.P. Viii.225.

3. H.S. Holdstrorth, Hist. of Law, i.419.

4. L.P. IV.5666: commiasion to John Taylor, master of the rollo, and othors, to rollove Nolsoy; and L.P. xix.II.527(24): tho oame to Sir Robert Southiroll and threo mastors in chancory, to reliovo Briothosloy.

5. Holderorth, op.cit., i.420; Fbloon, op.cit., pp.51. 
tho ninetoonth. 1 The roight of the ovidence 10, theroforo, againot any supposition that Cromroll actod ao a judgo in chancory.

A slight doubt is raisod by tho appoal to him of a dofondant in a chancery ouit. ${ }^{2}$ But John Clifford'a potition is addroasod to Crowoll as occrotary and moroly rontions hio masterahip of the rollo as an office rhich rould onablo him to help tho potitionor against tho chancollor'g hostility. The rording makes it quite plain that tho only judge in tho chancory rould be the lord chancellor himself. The caoo dragged on until Niay 1537 whon it wao decidod by Audoloy against Cromsoli's petitioner; ${ }^{3}$ his mastorohip of tho rollo does not seem to have onablod Cromrell to speed up or ineluence a caso under consideration.

Though Cromolt was not commisoionod to hoar caseg, thoro was some opecial business which ho had to transact as mastor of the rollo. Porhaps nothing particularly apportaining to the office ras implied by his acting in land purchagoo for

1. Holdsriorth, op.cit., 1.421.

2. L.P. Vii.1631(2); Tho original has boen oxamined (P.R.O. SP $1 / 88$, 11.66-7). Tho lottor under ibid. 1631(1) bolongo to 1528 as statod in L.P., and thoroforo to Cromirell's privato practico in thoso early yoaro. Not only is tho dato with its day of tho roek conclusivo, but thero is also tho wention "laystor lorrycho... my oeriaunt" (not in the extract). Sir Robert Norrich was appointed chief justice of the comon pleas in Noversber 1530 (L.P. iv.6741[22J). 3. L.P. xii.I.1138. 
tho crom, for ho had taken ouch action boforo ho bocamo maater of the rolls; but whon wo find him aonociated in ouch a parchago with the chancellor, attornoy-gonoral, and oolicitor-gonoral, wo may roll oupposo that ho was acting by virtue of the one legal office he held. 1 of more intereot is the comisaion to him, as master of the rollo and jointly with tho chancellor, which gavo him porrer to grant denizations. 2 The patent rollo prove that ho used the porrers thus conferrod only a littlo.3 Ao master of tho rolls he ras also commissioned to take compositions for firot fruito undor tho act of 26 Honry VIII c.3; tho detailo of this are discussod in anothor placo. 4

It rould appear, then, that the mastorahip of the rollo did throe things for cromtell. It greatly increasod hio incorso and gavo hits a house; it gave him control over tho clerical, that is the administrative, oide of chancery; and it gavo him an offico of antiquity and such standing that during those years ho $\nabla 20$ usually doscribod as chief secretary and master of the rollo. He seoms to have attonded to

1. L.P. Viii.362. Ho is described thore as chiof socrotary and mastor of tho rollo.

2. Ibid. $291(17)$.

3. P.R.0. C $66 / 665$ (26 Henry VIII, part 2), where of 105 denizations entered on the last three membranes 11 are marked "per T Cruntoll". Thoro are no traces of denizations granted by Crowrell on the other patent rolls of 1534-6.

4. Belor, Chapter III, Soction IV. 
tho admintotrative dutios of tho offlco rathor than to ito legal and judicial poosibilitiog. Thore io nothing to ohor that ho altorod ito scopo or functiono in any ray, or gavo it an increased importanco in tho official hierarchy. In vior of tho fact that tho mastorahip of tho rollo Interested cromell mainly for the control it gavo hin oror the chancery clerks, this oooms tho right place to diocuso the for changes which took place in tho ohancory organioation during his rule, and to soe whothor ho ras concornod in thom. By far the most intoresting dovelopment is tho appoarance of an official apparently chargod mith oxamining tho patento granted. A varrant doliverod into chancory on 29 April 1536 is annotatod " $\mathrm{R}$ Crippor exa[rinavi]t paton", 1 aftor which time Cupper'o namo becomes ever more erequent in the filoa until noarly every narrant is thus countorsignod by him. Tho he was 18 uncertain. Ho ras not one of tho oix clerks or clorko of tho potty bag in 1535, for thoir namos are listed in one of the accounto of Cromeli's income as mater of tho rollo. 2 He ras, horrover, delinitely concernod with tho rriting and pasoing of eranto, as is proved by a noto vritton by a clerk of tho oignot on the back of a rarrant dolivorod in septomber 1540, in which Cuppor io reoueoted to paso a oignod potition 08 warrant for the great soal in the aboonce

1. P.R.O. C $82 / 708 / 41$.

$$
\text { 2. P.H.O. SP } 1 / 105,1.24 \text {. }
$$


of the lord prify gool. 1 H1o dutioo woro probably to oxamino grants and comparo thom with tho rarrant, 80 that thoy rosomblod and anticipatod those of tho office of oxaminoro of lottoro patont, firot grantod in 1547.2 so Cuppor bogan hio activitios during the timo of Cromoll's mastorahip of the rollo it seoms pormisgiblo to 800 hore a reform sponoorod by Cromell himsolf.

To must furthor noto tro nor clorkohipo oatabliohod by patont. Though both roro earlior than Cromrell's appointment to tho rolls, thoy both involve him to a cortain extent. There was, firotly, tho clerkohip of diopenoations and facultieo, an offico creatod by the act of 25 Henry VIII c.21. The clerk' duties rore to prepare confirmationo undor tho groat seal of diopenoations and facultios granted by the archbishop of Canterbury who by the atatute had taken oror tho pope's porrors in that rospect.3 Not only, therefore, was the office an outcomo of Crommell's genoral policy, but it was also granted to Cromboll's old friend and sorvant, stophon Vaughan. 4 Tho appointwent was the wore oupprioing becauge Vaughan had no training in the chancery so that his patent had explicitly to atato that he was not to bo handi-

1. P.R.O. C $82 / 772 / 2$.

2. Mexroll Lyto, Great Serl, p.266.

3. Ibid., p.277:

4. L.P. Vi1.587(13), whoro tho oxact nature of tho office is not mado plain. Cf. tho original, P.R.0. C $66 / 663,4.37$. 
cappod by the lact "quod profatur stophanua in Curia Cancolzario nostre cducatus sou in cursu eiusdor oruditus non oxiotat". Such an appointment, over tho hoado of trainod chancory clerks, of such a man, can only havo boon due to Crommoll's personal influonce. Noithor his lack of oxporience, not the fact that he was ompowered to omploy a deputy noom, however, to havo provonted Vaughan from corrying out the dutieg of the office during such time as ho was in England. Tho trangcript of a lettor patont on a momoranda roll adde his name, with tho explanatory note, necesaary porhapo bocause of the novelty of the office, "Stophanus Vaughan Regio maiestatio Ad facultatos clericua". 1

The other ner office, that of the clerk of the leareo, who was to "rrite, expedite, and exemplify all Lotters patont of grants of land",2 datos from 11 June 1534 whon it was Eranted to John Croke, one of the oix clerks. 3 The patent appointed him an annuity of 220 backdated to the provious Easter, thuo proving that ho had alroady hold tho offico for oome time. Croke was an old-e日tabliohed chancery official, ono of tho six clerks as oarly as 1523,4 and a mastor in chancery in 1554.5 Ho was al80, howovor, a friend of

1. P.R.O. E 159/315, Commia, Lifchaolmag Torm, Recordo, m.18.

2. Lasmell Lyto, Great Seal, p.274.

3. P.R. O. C 66/665, m.27. L.P. Vil.922(6) doscribes him simply as "clork of tho onrolmento".

4. He ras wentioned in thopact of 14 \& 15 Henry VIII c.8.

5. Sandere, orders in Chancery, p.10. 
Cromoll's tho had originally appointed hili ono of tho oxocutors of his clorknip may, of course, havo had nothing to do with Crom7011, but the lact of their friondehip in suggegtive.

There rould appoar to havo boen no other changes in tho organisation of the chancery during the $1530 \mathrm{~A}$. The chancery as a department was sufficiently doveloped and otorootypod to require no attention from Cromell in hio reforming activitios. He ros content, as master of the rolls, to supervise a rocrotariat whose routine had become fixed long before his time.

1. Worriman, 1.63, n.1. Lator Cromiell replacod Croke by Vaughan. 


\section{Lord Privy Soal.}

On 2 July 1536 Cromwoll was appointod to bo koopor of tho privy seal in succossion to tho oorl of Wiltohiro. 1 Wiltohiro'g position an ono of tho ling'a chiof councilioro had boen doubtful ovor since tho fall of quoon Anne, his daughtor, and Cromrell had in fact boon carrying out tho dutles of tho office for at least a wck boforo the appointruont took offoct under hie patont. The writ to the exchequer which orderod tho first paymont of his feos 0180 authoriood paymont for tho period 24 June to 2 July. 2

Cromiell thus becane the fourth great officer of state, ofter the chancelior, treeguror, and president of the council, and for the rost of hio lifo ho Eovornod the country, and controllod the adminiotration, in that capacity. Eron after ho had boen Granted the greater but empty dignity of lord great chamborlain of England ${ }^{3}$ he ras still habitually addressed ao lord prify oosl, for it ras as ouch that he hoadod tho governwent. The office provided not only a high placo in tho official hierarchy but also a handooro incomo of 2365 a year, specified in his patent of appointment as derived from the custors colloctod at rarious porta. 4 This foe of onc pound

1. L.P. $x 1.202(3)$.

3. On 18 April 1540 (L.P. XV.540).

4. 20-2xom the port of Poolo, \$56.13.4 from Briotol, 2200 from tho petty customs of London, and $\$ 18.6 .8$ from Plymouth and Forroy. 
a day had originally boon intondod for tho maintonanco of the koppor of the privy ooal and his otaff rhon aboont from tho roynl hougohold, but it had long ago bocomo the lord privy soal's porsonal salary. 1 Unfortunately thoro survivo no accounts of Cromeli'g with detallo of official incomos for lator than tho beginning of 1536 so that we cannot toll whother he roceived moro from the office than this £365. It is, howerer, likoly that he shared in the profits of the ooal. 2 As Gardinor's eclipes had been marked by his losa of the oocrotaryohip, so tho fall of the Boloyn party bocamo manifoat Fith Filtohire's 100 of tho koopership of tho prify goal, and in both cases Cromrell stopped into the vacancy. All the other offices which he held had alwaye been vacant through the doath offosignation of the last holder, but tho tro pooitions which gave hit his chiel politicel and miniotorial porrore wore acquired at the cost of dispossegsing one of the king's chiof councillors. It $\nabla e s$ posaiblo to do this bocause tho eocretary had no patent of appointront at all, whilo the lord prify oeal'o patent granted the offico during ploasuro. Bath officos nore therefore frooly at the king's dieposal. Fo fool juotified in concluding that cromell took his minor offices, which vore to him mainly a means of particuler control

1. Tout, Chaptorg, T.831.

2. In 1634 the keeper of the privy seal 780 ono of the officiels euthorised to profit from tho process by which tobacco liconceo vere granted (Aaxmoll Lyte, Groat Seal, p.355). 
Within opocifiod dopartwonto, as thoy happonod to fall racant, rhilo tho socretaryohip and tho kooporohip of tho privy ooal roro his doliberate choice. Ho intended to govorn through them bocause he oar tho pooglbilltios inherent in thois lack of lised dutios and delined scope.

In a ray, it wao the choico of tho oocrotaryohip which rao deciaive. That office gave him all the porer ho could want, but horrovor much lastro ho might add to it it was not yot ono to bo hold by a poer, ${ }^{1}$ and apparently it rao thought that the timo had como for the king's chiel councillor to bo rewarded with a title of nobility. It may of couroo haro been the other ray about, for a lord privy soal who was noi ther a biohop nor a poer $7 a 8$ as unheard of as a noblo oecrotary. Tho detes of Cromirell'o promotion to tho koeporohip (2 July or 24 June) and of his creation as baron Cromell (8 July) 2 are too close together for any argument to rost on thoir sequence. It is likely that both oteps rore decided on together and taken conjointly. If Cromoll ras to be promoted, the office of lord privy soal was the obvious noxt stop. Not only was it the only high office of state occupied by a councillor fallon from grace and thorefore readily romorod, 3 but

1. The lirot oecretary of otate who ros also a poer 7as Lucius Viscount Falkland, appointed in 1642 (Evans, Princinal Secretary, p.350). Burleigh, unliko Crommoll, rolinquished the oocrotaryohip in 1572 mon he ras croated a pecr. 2. L.P. $x i .46,202(14)$.

3. Tho lord chancollor, Audeloy, was not the man to oppose 
It 780 al80 tho traditional promotion for the oocrotary. 1 loroover, it alone offored pogalbilitiog almilar to thooo Thich Cromwelt had exploited in the secrotaryship. Tho chancellor ras tiod pp with legal buainose and had loot hio placo at tho head of the administrativo machino; wo have oeon thet Crommoll appoaro to have arolded the offlco doliborately.2 Tho lord treasurer's departmental dutios voro to superviso the exchequer, but the oxchoruer ras the loast important of tho great financial departmento of the time. Tho offico did not regain great practical importanco, in addition to ito traditionally high otanding which it nover loot, until the roforws of Lary's reigh reatorod oxchonuer supromacy in the finencial field. 3 Ao for tho prosident of the council, hio position 78880 obscure and puroly titular thet wo might doubt hio existenco if ho rero not mentioned in tro acto of parliamont. 4

The office of the lord privy goal, on the other hand,

oither Cromell or Honry. The officos of lordo treasurer and president of tho council wero hold by the two dukeo, llorfolk and Suffolk, whom Crommell could not afford to antagoniso. Loreover, thoy froro firmly onough in favour, oring to a oigilar absonce of indepondence of mind.

1. In tho fifteenth contury oix oecrotarios bocamo kooporo of the privy seal (J.0tway Ruthron, King'g Socretary, $p .87, n .2$ ).

2. Above, pp.11111.

3. Thorefore, Burleigh (was he modolling his caroor on Cromvell'g?) took first tho offico of lord privy seal but exchangged it for that of lord treasurar as soon as pobsible. 4. 21 Henry VIII $c .20$, and 31 Honry VIII c.10. Ce. A.F.Pollard, in E.H.R., 2xxvil(1922), pp.3531. 
provided all the opportunitioo for a promiorohip which had also boen inherent in tho humblor offico of tho nocrotary. Its holdero during tho rolgn - Ruthal, Marny, Tunotall, and Filtahiro - had all boon great mon in tho stato and loading councillora. Tho roports of tho imporial ambasaador shot, for inotance, how largo a part tho lord privy goal might play in diplomacy. Betwoon Folooy's lall and Cromoll'n ribo, Miltshire 733 cloarly tho king's chief councillor aftor Norfolk. Novertholeas, tho uso mich Cromoll mado of tho offico ras poculiar to himsolf. There is no nood to rocito again tho ophoreo of govornmont with which ho concornod himsolf ao lord privy soal; thoy havo boen sot out in dotail in our account of hio secrotaryohip. Cromeli'g rork continuod unchanged after ho took on hio notr dignity, and tho significance of his promotion $7 a 0$ social and porgonal rathor than political. Apart Irom its general powere ao ono of tho groat offices of stato, the keoperahip also involrod dopartmontal dutiog. The lord prify seal was vory dofinitely tho hoad of the privy coal office, but thio and Cromoll'o dealingo With it will have to bo discussed in anothor place. ${ }^{1}$ Furtherwore, tho lord privy soal was regarded as tho or officio president of the court of requeots. Although this ascoclation ras never ostablished by anything more dofinito than

1. Bolor, Chaptor 4, Soctions II and III. 
'custom or, at the woot, proscription, and although tho normal practico of the oirtoonth contury did not oupport it, it wan considered so cortain by logal writore liko Coko that wo wust concorn ouroolvos with thio aspect of tho lord privy 8081's dutios. ${ }^{2}$

In Cromoll'o timo tho court almayo described itsolf simply as tho king'o council, but it was rolorrod to by othors as a court, 2 sat regularly at Footminoter, 3 and shored cloar efidonce of a fizod personnel. Tho phraso "court of requestan occurs for the firot timo in its ordor books at the beginning of the Ililary terw, 20 Henry VIII (1529), whoro a list is given of "suche Counoaillours as bo eppoynted for the Horyng of Porrer mennes coures in tho Kynges Courte of Requestes".4 The lord privy soal is not in tho list of fifteen names which are headed by tho bishops of Linooln and St. Asaph and tho deen of tho chapol. Ho aro also assured that there is no oridence that any koeper of the privy oeal took an active part in the affairs of tho court under Elizaboth. 5 On the other hand, bishop Foxe as lord privy soal

1. Cf. Sir E.Coke, Fourth Inotitute, p.97: "whorein the zord Privio Soalo at his ploasure and the lastors of Requosts do assomblo and gil."

2. A defendant rould declaro himsell ready to abide by the decision of "thyo honorable Court" (P.R.O. Req $2 / 1 / 18$, no.3).

3. Leadam, solect Cases in the Court of Renuesta, pp.xii if.

4. P.R.0. Rog 1/5 1.86. Tho list is not lator than the dato given becauso the Sir John Huse mentionod in it ras created a peor in the 1529 sesolon of perliament (G.E.C., Vii.16). 5. T.3.J.Allsobrook, Court of Roquesto, p.5. 
prooided ovor its origino; ${ }^{1}$ in 1608 a lotter mas adarosuod to tho thon lord privy seal, onumerating tho shortcomines of tho court and suggegting that thoso might bo holpod "11 it plosood your lordbhip to sracc and honour the court nometymoo with your prosence" and if tho usual judgo roportod to him daily on what had takon placo; ${ }^{2}$ and in the roigh of charloo I a reforming lord privy soal at lagt rovived Foze's activitiog in the court. 8 It therofore sooms that we may bolloro Coko. The lord privy seal was, at loast in theory, opecially connoctod with the court of requesta, and ro mat souk to discoror whether Crowrell had anjthing to do with it.

It soems quite cortain that Crommoll did nothing matorially to offect tho growth of the court. Though it wight continue to call itooll tho king's council in gonoral tormo, it was a cloarly defined branch of that body by 1529, with ito residonce fixed at tho Thite Fall and a lefinito body of councillors dolegated to do ito iork. 4 lor does it appoar that the work of the court oithor increased or decroased noticoably during the time of Cromrell'o oupremacy. The

1. A.F.Pollard, Nolgoy, p.83. Professor Pollard suggeoted that It ras Foxe'g long association with the budding court which ostablishod the connection.

2. Printed by Loodam, op.cit., pp. xcvi if.

3. The oarl of lanchegtor, ibid., p. xlvii.

4. Ibid., pp. xil 1 .. By 1531 tho order books at times use tho phrase "court of requostg" (P.R.0. Req 1/5, 1.254 ot Q.1.), though later they revort to an exclusive use of "king council". 
question whothor Cromoll himsolf oror gat in tho court to wuch moro difficult to anowor. Tho books of ordero and decreeo do not mention his name, but thoir entries aro after a pattorn and nover apocify any of tho mombors of the court. 1 To are, therefore, forced back on the proceodingo, the only other class of documonts in the court which fo extant for this period. The 172 caseo mhich re can at prosent be cortain belong to the ycars of cromell's mo have been examined; though there are probably more, the number is largo enough to permit oomo genoralisationo. 2

liany of the documents in the files bear notoo and ondorsemento in the hand of the clork of tho court ${ }^{3}$ and signed by a number of king'o councillors. Thero aro oight such councillors names in the period with which re are concerned: Vicholag Hare, Edward Carne, Thomas Thirlby, Richard Sampson (biahop of Chichestor), John Tregonmell, Wiliiam Sulyard, Richard Folman, and Edmund Bonner. 4 of those Bampon, Sulyard,

1. R.R.0. Raq $1 / 5-7$.

2. All the c8gos have boen gone into which are dated 27-31 Henry VIII $(1535-40)$ in Hunt'a Calendar at the P.R.O. It wust bo cupposod that among thoso he left undatod there aro somo at any rate belonging to that poriod, but thoro could bo no thought of going through thow to dato thom, and the 172 datod onos are enough to justify doductions.

3. Richard Turnour, tho gonior clork of the privy goal (Lambard, Archoion, p.230).

4. A ninth, Fobort Southroll, occurg on a document marked by a rodorn hand 28 later than Larch 1539 (P.R.0. ReQ 2/9/134), but Southroll ras apparently not connected 7 ith the court until 1541 (D.N.B., 2viii.701b). 
and Molman wore in tho lint of 1529, ruotod abovo. Tho nignotures appoar aingly or in pairs; onco Iaro, Tro.jonwoll, and Thirlby are asoociatod, 1 and tilice wo find four nameo. 2 There, then, would $800:$ to be the men who did tho actual work of the court. Admittodly, it might bo possiblo to argue that bigger men, moro important councilloro, wore propont, and that tho smaller fry were deputed to seo to tho isoue of privy oeslo for appoarancer, or to tho comittal of cases for local onnuiry. But the same mon also oignod the decroes of the court. 3 Interrogatories and lotterg concorning caser wore addreosod to Hare and Thirlby; ${ }^{4}$ a potition mas endorsed to the effect that "yt is ordred by S' Nycholas Hare Knyght, on of the kinges honerable Councell"; 5 a delendent was ordered to appear "per mandatum magiatri Hare", an order transmittod "per nuncium camore"; 6 Haro himself wroto a letter to a defondant in torms which show him to have beon in charge." Porhaps no may already call theso councillorg who did the actual rork the mastere of requesta, though thoir number indicates that tho final oyotom of two mastero-

1. P.R.0. BөQ 2/3/147.

2. Ibid. $3 / 112$ - Sampson, Hare, Carno, Thirlby; and ibid. 12/184 - Hare, Thirlby, Bonner, Carno.

3. P.R.0. Req $1 / 5,11.379,435$ (Tolman and Sulyard); Raq $2 / 3 / 31$, 147,187 (Haro and Tregonteli).

4. Ibid. 4/104 and 6/172.

5. Ihj. त. 3/78.

7. Ib1d. 6/107: "othemyos I shall bo drovyn of Iustico at tho roquest of the oaid partyo to oend for you by proces." 
in-ordinary had not yet ovolvod. 1 At any rato, tho ovidonco ia clear on two pointa: thore prore a numbor of councilloro opocially dotachod to do tho work of tho court of roquosto and actually angagod in doing it, and tho lord privy ooal roo not ono of thom. Thero is nothing to show that ho ovor took an active part in this rork.

Thilo romembering that an argument basod on tho aboonco of ovidence is almays liable to be overthromn by the diacovory of Iresh ovidence, wo might yot bo contont with this dolinito assertion. But there are tro cased among the 172 invostigated in which Cromell appears. The firot is that of Henry Rood (aliag Sagon) V. Sir Thomag Tyroll, to be datod roughly into tho second half of $1538 .^{2}$ It io not at first oight difforont from any other case, oxcept that the plaintiff addresoed hio petition to tho "right honorable the lord pryryooale", in defiance of the cuatom that billo in the court of requesto mere addresood to the king, or to king and council.

1. In this connection it is of interest to note that tho tro most Irequent oignatorios, and the only tro common laryors in our list (the others Fere all rell-knom civilians), viz. Haro and Sulyard, do not appear ovor to havo acted togethor. Hare lirat appoaro on 22 November 1537 (P.R. 0 . Roq $2 / 2 / 162$ ), and Sulyard last on tho 27 th of that month (ibid. 8/284). He $\quad$ ras appointed to the council in the marches of Vales torards the end of 1537 (L.P. xil.II.1094,1152); nas Haro his succegsor as reprosentative of tho common lam?

2. P.R.O. R31 2/1/18. Tho privy seal includod in tho filo is ddtod 1 Juzy and ordors an appearanco by 14 0ctobor; an endorsement io datod 29 Jund 1538. 
This samo potition, horovor, boars ondorsomonts (ordors for defendant's appoarance and commissiono of onquiry to local magistratos) rihich are signod by Haro and Carno and provo clearly that the case went through tho usual stages in tho court. So doos tho whole of the 1110, which containo plaintiff's potition, defendant's angrer, combios on under the prity soal - all part of the regular procoduro. Fhy, thon, ras tho potition addressod to Crommoll?

The anstror rould soom to lie in its contonto. Rood otated that his cuarrel with Tyroll ras of long standing. Ho had eppealed four timos to the duke of Norfolk who had eventually ordered Tyrell to leave the plaintiff in peace, but after some timo now disturbances had provoked an oarlior appeal to Croumell, with again a terporary ond to the nuisance. liow, however, Typell was once more causing trouble, and Recd was therefore once again appealing for justice. Ho appealed to Cromell porsonally, but there is no doubt that his appeal was invertisated by the court of roqueste. Way wo not conclude that Crowell grew tired of so poraistent a potitioner, or was doubtful of himself achieving the dosired result againgt a man tho had alroady disoboyod his instmations? Perhapo, too, he did not wish to antagoniso a man rho ras one of the leading gontlomon in his county and had, for Instance, boon of somo uso to the governmont during tho 
northern robollion. ${ }^{1}$ It soomo cloar that for oomo ouch roagon he proforrod to loavo tho mattor in tho hando of tho ostablished court into whoso juriadiction thio "poor man's causo" belonged. Thus ho passod on a potition moant for himoolf porsonally, 80 that it 780 aftorrards handlod by tho ugual officoro of tho court, in the mannor usual there, a fact risich tends to confirm our argumont that Cromroll did not porsonally attond its sittings. Mo tras potitioned by many men, many of them poor, but only ono auch potition is found in the rocordo of the court of roqueota. Uoually ho doalt with ouch mattoro directly, as ho had dono with Rood's oarlior potition, but ho ankod tho court to sottle this particular businese.

The othor caso which wo mat considor does not at firot oight fit into tho picturo horo prosontod. Howevor, it actually confirms our vior that Cromoll did not receive potitions as the preaidont of tho court of requests, but rathor as one of the king's councillore and the most porertul oubject in the land. The case is that of simon stretton $\nabla$. Tilliam Butlor. 2 Here wo find none of the procedure uaual in the court of requesta. The filo consiots of fivo documents: an ordor to defondant oigned by Live Farrickghiro J.P.日, a petition (or rathor, a rowinder) from plaintiff to Cromoll, a porsonal letter Irow Cromoll to throe local wagiotrates of

1. L.P. xi. 615,642 2. P.R.0. Feg 2/4/203. 
Warwickohiro, thoir roply, and mitno0000' deponitions taken by thom. The only olgn that the pepore bolong to tho court 10 an endorromont on the lagt namod documont, "dot' oot ut infra". Thio is vitton in a differont hand from that which rroto "consorning atroton" abovo it; tho lattor hand is ono shioh occure froquently on the backs of cromrell's papers and must therefore havo bolonged to ono of his privato clorks.

These documonto ouggent the proceduro of tho court in a rudimentary ray. Plaintiff'o potition vas apparontly roplaced by a porsonal intervior and a oubsequent vritten reminder that Crowell had promised aselotance. There in no dofondant's answer, but Cromoll's letter shove that ono local gentlemen liad ritten on his bohalf. Inatood of a combission undor the privy seal there if an informal lotter signed by Cromoll, which.18, howovor, described by the recipiente as a "lottro comyasye". Their congrier ia not a formal cert1ficato rondored to the council but again an informal lettor, this time to Cromell. The documente make it quite plain that Crowell dealt with the case personally and on his om. Thore is no montion of court or council, no name or eignature of one of tho regular judgeg, everything is on paper instead of parchwent. To havo hore, in lact, an example of the ray In which Cromell handied potitions addroosod to himsolf; he uoed the method common in tho council and conciliar courts of 
gotting tho facts ostabliohod by the local maglotratoo boforo dociding on tho morits of a caso. Thoro is nothing in thio to show him acting as a mombor of tho court of roquosto.

The quegtion how the file camo to be among the recorda of the court of roqueota can only be ansmerod by a conjecture suggegtod by the endorsements on the dopositions. Haring discorerod the facto of the caso Cromrell epparently handod the papers to the court for a docroe to bo mado, a procodure Which may have seomed advisablo to him bocause provious attempto to secure justico for the plaintiff had apparently failed. This roason is vory similar to that offorod as an explanation for tho earlier caso. Together, tho tro casos suggent that rille Oromell did not habitually use the court of renuegto for the redrose of Erievencos brought to hio notice, and rhilo he did not prosido over the court in person, he yot employed its authority - the authority of the king'o council - in cases where leso formal and theroforo 1088 authoritativo otops had beon unsuccosoful.

The koepership of tho privy soel did not, thercfore, involve Cromoll in the routino work of a judge, and he did not concern himself with tho court of requesta in any particular ray. The rorking of the courta, whother coumon law, chancory, or conclilar, ras not one of the reasono for which ho acquired any of his many officos. As lord privy soal ho hold a high 
position and oarned a considerablo nalary, and an lord privy goal ho suporintendod the government of Englend. Though ho did not neglect the departmental buainose of tho prify ooal, that rag but a omall part of the mork which tho offico brought nim. Loro ovon than tho principal gecroteryohip, tho groator titlo and offico onabled him to otand forth as tho king'a chief miniator. 
VII, The significance of the offices.

Crommell's ofx major offices have now been examined. We have left out tho two eccleaiastical titlos of vicargeneral and vicegoront in opirituals because thoy do not concern this otudy of Cromoll's lay adminiotration, and a number of leseer offices most of which are in any case unconnected rith the central government. ${ }^{1}$ We have also left out the mastership of the rarde which Cromroll nover held, despite allegations to the contrary. ${ }^{2}$ What are the conclusions that omorge from this survoy?

It ie plain, first of all, that none of these six offices mero sinecuros. Cromell did the rork of the master of the jerrols; he did some at loast of the pork of the clerk of the hanaper, the chancellor of the exchequer, and the master of the rolls; he created for himell the imonse amount of work which he did as secretary and as lord privy geal. Every one of these poste, except perhaps the mastorghip of the rollo, was given a ner ocope, greator porers, a higher otanding, through boing held by him. His main concorn cannot have been with the money the offices provided, for in no case have we goen him maiting large profits out of hio official positions, and such eridence as there is has suggested that he

1. Of. the list in Morriman, 1i.2831., to which ohould be added the survejordship of the king's roods (below, p.167, n.l).

2. See the note at the end of this chapter. 
never got more than tho bare minimum due to him. The incomer of the masterghip of the rollo, of tho lord privy ooal, and poseibly thet of tho oecretary, Jero largo but not 80 large as to suggeat that thoy provided tho wain attraction. It has already boen said soveral timos that Cromoll'a reason for holding those offices conet primarily have boon a dooiro to control the government by means of direct poworo in various branches of the adminigtration. We have pointed the contraot botwoon him and Folsoy. Both rero tho king's chiol minioters, exercioing a greater powor under the crown than perhapg any oinglo man had over held before, during tho rolgn of a strong king. But while Woloey concentratod on his work as a judge and a loreign minioter, sooking poror in the otar chamber and in the councils of Europo, Cromerell turned to the rpork of detailed oupervision of the adminiotrative machine for rhich his abilitios 00 peculiarly littod him. Ho deliberately neglectod aspocts of his offices rich would have given him the porrors of a judge, and we can only conclude that he ras not interested. The nature of his roork w8s less obviously brilliant than Fology's; by the same token it ras also more onduring.

At the same time, thero is a danger in thus discussing Cromell'g offices one by one. They mero held together and by one man, and the Iirat thing that otrikes one lo the wide 


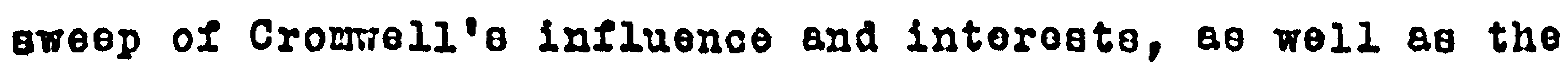
perfectly incredible powerg of rork which he mat hare posoese日d. During the tro years when he was master of tho rollo he also held the oflices of principal oecretary, mastor of the jorolo, clerk of the hanaper, and chancellor of the exchequer, not to mention other minor tasks in the gorernment which would also require his personal attontion, ouch as tho surveyorahip of the king's moods, or a combigalon of aeroro, or a commisaion of tho peace. In March 1540 ho $\mathrm{war}$, at ono and the oame time, lord privy seal, principal oecretary, and chancellor of the exchequer, in adition to his ecclosiagtical officer; we may ouppose that the dutier of tho jowelo and the hanaper were by then carried out by his follow, Williamo and sadier. Whon he foll, threo montho later, ho had exchanged the secretaryahip for the titlo of great chamberlain of England; his work and industry had remained the same. Throughout these yeare he was, moreorer, the man who gulded the king'o policy and diplomacy and organised parliament. It seoms almost incrodible that one man, with only twonty-four hours at his dieposal every day, should have been able to do so mach. But it is well to remomber that his pluraliam, glaring though never criticisod by contemporaries, was not motiratod by grood or ostentation. Tho besio of his magniifcent collection of offices was the de日ire to control erery 
branch of tho adminiotration, and to do 00 , as far ad possiblo, through the poesegsion of an office and a otanding in every branch.

From one point of vier, Cromell's offices fall into two groups: the departmental posts offering a limited ocope in a dofinite field, and the socretaryohip and keoporghip of tho privy goal which carried all-ombracing powers without traditional limitations. Anothor difiaion is, howoror, more interesting from an adminiotrative polint of view. Thero aro, firstly, the throo Iinancial offices - jerol house, hanaper, and exchequer. They wero the first appointwents which Cromwoll hold, and their choice indicates that his lirst concern was to gain control of the financial machinery. He followed heroin in the footatops of ouch a leading Iinancial official as Sir John Heron who had combined the offices of treagurer of the chamber, charberlain of the exchequer, aupervisor of cugtoms in the port of London, clerk of. the jerol house, and clerk of the hanaper. 1 It mast have seomed in 1533 that Cromell was making for a similar accumulation of linancial olfices in one hand. Howeror, he was something more than a leading civil oervant and rould not concentrate all his energies on rolatively minor administrative posts. Nevertheless he acquired a footing in the chamber machinery of linance, in

1. CI. A.P.Nerton, in E.H.R., $\operatorname{xxil(1917),~p.357.~}$ 
tho treasury of the chancery, and in tho exchequer, and thereby enabled himself to become a miniater of financo.

The second group of offices, too, has a common donominator. It provided control over the threo gocretariats of 8tate. The clerko of tho oignet, of the privy oogl, and of chancery were the eubordinates of the secretary, lord privy ooal, and master of the rolle. Here again, oomething more than coincidence, oome delinito plan, ouggesto itooll. Naturally, the firet condition of porer under Henry VIII was a personal otanding at court guarantooing the possosolon of the king's ear. But anyone who wishod to govern through a close control of the machinery of government would have to make himself master of those who provided the means of government and of those who were the agents of the executive. He rould have to be master of the inancial machino and of the bureaucracy. Cromwell's cholce of offices proves that he roalised this, and that he was working towards just ouch a direct and personal control of the machinery. Wo must therefore now Investigate his relations with these oections of the administration, the financial and clerical organisations. 
Iilete to Chapter 2: Magter of the Warda,

In hie lifo of Cromeli in the Dictionary of National Blography Dr. Gairdner otated that in 1532 Cromwell ras made moster of the king's wards, 1 and the asoertion was repeated by Lerriman. ${ }^{2}$ The office was normally granted by patont, but there is no trace of Cromell having obtained one. The oridence must therofore bo circumetantial rather than direct. It is true that about the end of 1532 there are to be found certain indications that Cromell hold the office. On 16 September, Sir John Lamplough wroto to him that "the saying here is ye shulde be lastor off the Fardog", and went on to essure Cromrell of his readiness to "doo the Kynges Henesse ouche seruice Concernyng the same as shall pleyes you to Comand me". S Simllarly, a gentloman of Cumberland wrote to him on 18 0ctober: "Sir, hit his shewrt me $\mathrm{y}^{t} \mathrm{z}^{\mathrm{\theta}}$ ar mastor off the kynges wardes, qrych I wald be glad yroff, \& yff so be $y^{\theta}$ hade neyd off a substanciall feodore" - and be proceoded to outline the local difficulties of that position. 4 Trice wo find letters addressed to Cromnell as "Lastor of the kyng our Souereign lorde wairdes" and "maister of the kinges wardes"

1. $D_{2} \mathbb{N}_{2} \mathrm{~B}_{\text {. , }} \nabla .198 \mathrm{~b}$.

3. P.R.0. SP $1 / 71,1.38$ (L.P. V.1317)

4. P.R.0. SP $1 / 71,1.138$ (L,P. $\nabla .1447$ ). L.P. here contain a bad miereading, "yen being rendered as "I" and "feodore" as "farour". The.hand is crabbed and the opelling peculiar, but thero can be no doubt that the reading given in the text is correct. 
respectively. ${ }^{1}$ The oecond addreas is of opocial interoot, for while the formar letter is concernod rith a wardahlp oo that the addrese may be the result of the oubject under discuseion, the latter 10 an appeal fros a priooner in the Torer and has not the remotest connection with rards. The lact that Cromwell ras master of the wards would theroforo $800 \mathrm{~m}$ to have been oufficiently rell known for any letter to be addressed to him by that title.

There are a good many other releronces to wardships in Cromell's correspondence, but they need be no more than indicatione of Cromellis wide control over every ophere of the administration and do not spocify that he was actually maoter. However, the four letters quoted would normally be sufficient ovidence and Gairdner might be considered justified, were it not for some stronger evidence on the other side.

The papere of the master of the wards himself never ohor Cromell active in that capacity. He appears in an ontry book of sales of wardehips, but only because he acquired tro wardehips, incidentally without haring to pay for them. ${ }^{2}$ The man who is conotantly ooen acting as master of the wardo is gir Milliam Paulet. 3 The patent roll rould ooom to dony completely the eridence adduced in Levour of Cromell's tenure

1. P.R.O. SP $1 / 71, \mathcal{1} .46$ (L.P. V.1327), and 76, 1.137 (L.P. V1. 551).

2. P.R.O: Hards $9 / 149,11.94,100 \nabla$.

3. C1., $e_{. g}$, ibid. 179, on ontry book of indentures. 
of the offico. On 21 Decombor 1534 Paulot ras appointod oolo magtor of rnedo, on ourrondor of tho patont of 3 Novombor 1526 Fhich granted the office jointly to his and Sir Thomag Englo110ld, then serjeant-at-lan and lator justico of the common plea. 1 Englofiold and Paulot roro thoroforo apparontly Joint mastora until Docomber 1534, elthough it io of courso poogible that Paulet alone should have dono all the work oron boloro that time. As a mattor of fact, even after tho timo when Crommell ras supposed to be mastor of the rards Englefield ras actine together rith Paulet as one party to an indenture, 2 and there surviver, filed in one of tho miscolleneous booke of the court of rarde, a royal marrant addrosed to Paulot and Englefiold as mastera of the rards and dated 16 April 1533.3 We may therefore take it as provon beyond any possibility of dbubt that a for montho after the timo whon at least lour poople thought that Crompoll was or ras to be mater of the wardo Engloficld otill held the offico togethor with Peulot.

The matter might be complicatod by a lotter which EngloIfold wrote to Crowoll, "Thankyng you for your payn taken for we in the Attenyng off wy Rocompens flor my offico off the lastorschlppe of tho kyngog mardog". Tho lotter is dated

1. L.P. $\nabla i i .1601$ (29).

2. P:R.0. Wardo 9/179, I.209 (26 Harch 1533).

3. Ibid. $149,1.43$. 
11 Fobruary and rao placed into 1532 in the Lottorn end Paporn. 1 There rould thus bo somo indication that Englofiold loft tho office at about the critical time. Horrovor, the dating lo wrong, as tro lecto prove. Englofield opeako of "the ner otatute" which will eneble him to adjudgo at Horelord aegizea murdero comitted in Faleo. The reforence can only bo to tho act of 26 Henry VIII c.6, peseod after liovember 1534. He also mentions the criminalo in quostion, "the Vaughano", and their acquittal was roported by biohop Loe, preoident of the council in the merchoo of Nalos, on 6 April $1535 .^{2}$ Englofield's letter, therefore, also belongo into 1535 and Iite perfoctly with the date of the ourrendor or hie patent. It follows that Cromell was never master of tho wards. There is no real difficulty in explaining the contemporary migtake regarding the office. It may have been due to a completely faloe ruxiour, or - which we think is moro likely it may have, besed on some genuine intention of Cromell's to acquire the office. He had so far secured a footing in tro of the financial departments of the adwinietration, and the king 's wards wero certainly an important source of the king's revenue. The idea that the mastership of the rarde would appeal to him was reaconable on the face of it. To one of

1. P.R.O. SP 1/69, 1.122 (L.P. $\nabla .799$ ).

2. LeP. Vi1i.509. 
the mastere, Englefiold, the offlce rao practically a oinocuro after hio appointment to the comon ploas, and ho may woll have thought of giving it up twe or throo yoaro before ho actually did. In that caso cromsoll mould certainly havo boen in tho running for 1t. If ho had any ouch intention ho nover carried it out, perhepo becouge by this timo (the ond of 1532) he ras becoming too busy on mattors of otate to take on yot another office rhich requirod dotailed rorls and immodiato attention from ito holder. In Paulot thero extremely able, experionced, and trustrorthy adminiotrator to hand who could be relied upon not to go counter to Cromwell'o mioher. Altogether, it probably seomed best to give up the idea, but not before enough indications had been given for people to assure for a fact rhat had only been a vague intention. 1

1. It may also be ouggested, though with somo diflidence, that Cromell's correspondents poseibly confusod the mastership of the rards with the masterahip of the roods. Cromweli was oharing the latter office rith paulet by the beginning de 1533 (cl. belor, p. 16, n.l), and the mistkke might quite eagliy be rade. 


\section{- Chapter 3.}

\section{THE FIMANCIAL ADMIMISTRATION.}

\section{The Adminiotration in 1531.}

It has become almost a commonplace to assert that finance was Cromeli's main occupation in the internal adminiotration of England, and he himsell appoars to have declared more than once that he wiohed to make his king the richeat that erer mas. ${ }^{1}$ Yet although his financial policy has boen described as "perhaps the otrongest point of[hig] domestic adminiatration", ${ }^{2}$ here has as yet been no attempt to assess his place in the hiotory of finsncial adriniatration. The changes which he wrought in the royal revenue, doubling the king's yoarly revenue, have found their historian; 3 his capacity as a man of business hao been fully recognised, though usually with an implied censure of his methods; ${ }^{4}$ it has also been realised that, with him, linance was only a meane, though an essential means, towarda establighing the royal supremacy in otate and church.5 Nerertheless, the effect of all this

1. As reported by Chapuys: L.P. Vil.1554; ix.862.

2. Uerriman, 1.133.

3. F.Dletz, Ensl.Gov. Fin., cho.9-11.

4. E.g., F.A.L.Fishor, Pol.Higt., V.447: "He ras a pastmaster in the art of taking inventorles and raluations, of checking accounts and devising Iresh sources of revenue."

5. Lerriwan, 10c.cit.; F.Dietz, Engl.Gov. Fin., pp.10311. 
actirity upon tho inancial machinory, upon tho agencios omployod in collecting and oponding money, hos not boen conoiderod. It 18. with this aspect of tho financial oyotom thet we shall now concern ourselres.

Wo are lortunsto in possersing a document which gives a clear picture of the organisation of the royal financer at the beginning of Cromreli's miniotry. This paper is headed "A Lemoriall for the Kinges Highnes, declaring the kynde of thingis Therein Rigith yerolye sorell hio Certein Rouenues ag his Casusll Rouenues, and who bo officers to his Highnes in that bohall". Thio deacription is not altogether accurate. Whereas the lirot part of the paper confines itoelf to stating sources of revenue and the officers respongiblo, there are a number of notos in the second part which refer to things to be done, arrears and debts to be checked, and the 1ike. There aro a number of additions in Cromell'g hand, and one of the last trio paragrapho, which wero added by a different clerk, was lirst drafted by Cromwell himoelf. The memorandum was 80 much for the minioter's as for the king's benelit, and it reads, in fact, very much like a otatewent dram up for the use of gomeone now to things. To ougge日t that it was written in anstrer to a request by Cromwell, or posaibly in his private office, at the beginning of his oupremacy, at a time when he was about to take charge of 
the royal Iinancog. 1

There is no logical arrangement in thio paper, and ito paragraphe must be rearranged if a clasoiflcation of the financial machinery fo to bo obtained from it. Ho may 11rgt diotinguleh tho normal oources of money, what the description calls the "Certein Rouenues", and wo shall soe that they come under three heads. There are the customo and subsidieo collected at the porte, for which the treasurer of England was responsible and which woro accounted for in the exchequer. Also within the responoibility of the exchequer were the sheriffo' eirme comitatus, the profits from escheated lando adminiotered by the cocheators, and the profite of the royel justice - Iines, amercements, and rocognisances in the central and local courte. ${ }^{2}$ These might be called established state revenues which by the reforms of Honry VII had become the sole regular gources of income in the exchequer.

By the side of the exchequer Henry VII had dereloped a net organisation, syotematised by acts of parliament in the

1. The paper is P.R.0. SP 1/67, 11.32-7 (L.P. V.397), and is given in full in App.A(I). The abstract in L.P. hides the characteristics of which ro hare spoken. It 18 undated, but from the fact that it does not mention the later ner revenues and was dram up for Crommell's benelit it appears that the date assigned in L.P. (tovardo the ond of 1,531) is substantially correct.

2. That is, chancery, otar chamber, king's bench, and common pleag, on the one hand; justices of assize, of sewora, of the peace, of quomum, und of over and terminer, on the other. 
reign of Honry VIII, under which the mogt important royel rerenues rere adminiotered by the treasurer of the chamber - and audited before two opecially appointed officiolo known as the general surveyors of the king'o lands. 1 The momorandum shows that these officials nere responsible for certain revenue adminlotered by themoelver, that is that derived Irom the king's om lands, ${ }^{2}$ and $a 100$ audited the accounts of a number of other financial officere. The magter of the rards, the ourveyor of liveries, the surveyore of vacant ecclesiertical benefices and of the money obtained for the regtitution of the temporalitios of ouch benelicer, the ourvejors of the king's roods, and the clerk of the haneper. mere all accountable to the goneral surveyoro. These various officials did not exiot on paper only. Fards and 11reries might be adminiotered by one man and were later com- bined in the court of wards and liveries, but in 1535 Richard Riche rag joined with Bir Thomag Neville in the office of ourveyor of liveries, 3 and Hovillo's olgnature is found

1. For the chamber 6yotom of financo cI. A.P. Nowton, "Tho King's Chamber under the Early Tudorg," E, H, R., Exxi1(1917), pp.348ff., a pioneor article which talieo the matter up to 1529, and below, section III of this chapter.

2. Cl. the ochedulos annexed to the acto concerning the office (6 Henry VIII c.24, 14 \& 15 Henry VIII c.15). The oubordinate agencios wore: thoso entrusted with tho lands of Tarmick, Spenser, and Buckingham, tho duchy of Cornwall, the chamberlains of Chester, of North and of South Walea, and the roceiverg of the principality of Falos.

3. L.P. $\nabla 111.632(34)$. 
Irequently on warranto for Iiverios anong the chancery warrant8. Special ourveyore for the monoy dorivod from vacant oe日e and for the restitution of temporalitios are not to be mot with 8 part of the contral machinery; ouch money peosod through Cromirel's orm hands in 1533,1 and it probably wont to the chawber both bofore and after this. 2 What was moant hero Fero progumably local officialo appointed as occasion arose, such men as Filliam Strangmayo who administcrod tho temporalitios of the vacant seo of York, 3 or Richard Streto Who did the same at Lichlield. 4 Surveyorg of the king's moods and clerks of the hanaper Fore, of course, Well-knom officials, and Cromell held both officoo ohortly after tho date of thio paper.

In addition to tho exchoquer and the general survoyors there ras the chancellor of the duchy of Lancastor, rosponoible for its revenues which rero collected by ito own roceivers, administerod by ito own receiver-general, and audited before its om auditors. He may include among tho reguler revenues those listed in the last threo paragrapho, which rore apparently added as an afterthought: tho revenues of Calais and its surraoundings, collected and expendod 10cally but accounted for beforo the generad ourveyors; the

1. I.P. $\nabla 1.228,717$.

3. L.P. V.822;
2. CI. L.P. IIV.II.13.

4. Ibid. $27 \%$. 
profits of tho mint; and the prosito of the activities of the king's learned counsel, derived from penal otatutes and from agreoments ontered by them on the king's beholf.

The other two sections which can be diocerned in the memorandum comprise tho uncertain or "casaal" part of tho royal rerenue. These pore the oume derited from rocognisances entered upon and forfoltod boforo tho various linanclal departmente mentioned above, and secondiy the debto of subordinate officials owing to their ouperior departmente. Theso mattors were again oubdivided to agreo fith the goneral organisation.

Thus thore was a considerable number of officiale charged with the collection of revenue, but we can distinguioh threo aain agencies responsible for collecting Irom subordinate collectors and for guditing accounts, that is to say, three main agencies responsible to the king or his ministor. These were the exchequer, the general ourveyoro (with the treasurer of the chamber who collected the rerenues which thoy audited), and the duchy of Lancaster council. In addition, there mere the smaller and independent departmente of the mint and of the king's lesrned counsel. The latter in particular do not really deserve the name of a department and rere apparently otill in need of organisation. ${ }^{1}$ It is with the three main

1. The memorandum states, as one of Cromell's projected 
departments that

Each of these lookod after a opoclifed ophore of tho revonue, acquired furthor irogular ours by tho bondo which both ito officialo and, ometimo, outaldero woro compellod to enter into, and made itsolf rosponoiblo for all the dobto pithin its organisation. What ras lacking in tho ochomo mas the unifying hand, the single eye to exercioe final suporvision, the one brain to co-ordinate the threo and thus control the whole financial adminiatration of the roalm. Tho lact that Crommoll was detorminod to occupy that empty placo has alroady becomo clear from hio officoo; ${ }^{1}$ it is furthor corroborated by this memorandum which, with Cromoll'd

relorws, that the money administered by them should be declared "by a booke so that his highnos might by acortayned therol yerelyo". No ouch rocords soomo to bavo survivod, so that it is doubtful whether the plan orer got beyond the otage of good intentions.

1. To those mentioned in Chapter 2 wo may hero add the ourveyorship of the king's woods, an office which did not soom important enough to deserve a separate section thero. Cromwoll hold it jointly with Sir Nilliam Paulot by the beginning of 1533. There are Irequent reforoncos to their activitios in the records (L, ${ }_{\text {. }}$. $\nabla i .210,231,406$; Add.839). No patent survives though one existed among Cromell's peporo

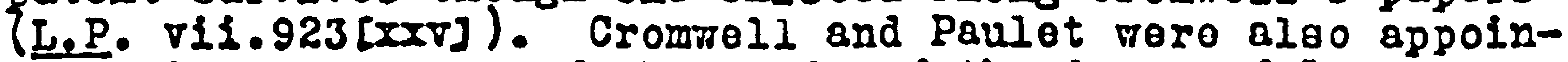
ted joint surveyors of the roods of the duchy of Lancastor (L.P. $\nabla i .1623$ ); from the ondorsement on it thio latter document io probably the one mentioned in Cromrell's catalogue. Their activities concerned mainly oalos of mood from the royal foresta; warrents authorioing theso nero olgned by both (L.P. Vi.5,6). Beopers of the king'o roods rendered accounts to them (L,P. Vil.46). There is no re cord of any loos boing paid to tho survoyoro, though on tho whole it is probablg that there rere some. An office under tho crom without profit to the holder rould have beon unique. 
correction and additions giving it point, ohowg that ho intonded to control ovory part of tho inancial oyotem. Tho outgtanding debto wore to bo ascortained and roportod - in thoory, no doubt, to the king, but in offect to Cromoll who ront over the paper and addod, for inotance, to tho dotalis of the Calais revenues a note that the identity of porsono in dobt to the king was to bo ostablishod, "So that lous might bo mado thorof spedelye". Trice the imporsonal noto was dropped; the officers of the duchy of Cornwall were to be examined, being apparently suspectod of peculation; and it is surprising to read in a scribo's handwriting that the profits of the wint for six yoars past shall bo enquired into "which I thinke do amount to a greato Sumo of monoy", until the page is turnod and the same paragraph appoaro, drafted in Cromell's om hand. The man who added theoe and other notes mished to knor and to ourvey all the agoncios responpiblo for collecting the king'o revonuer.

Wo can, therofore, bo certain that Cromoll oxercised a close and detalled control over every branch of tho linancial administration as he found it, but even among the throe main departmente not all branches can be of the osme intereot to us. To take first tho most stablo and loast important of them, the duchy of Lancester: all the money mich remained after peyront of ranning expenger, Leos of duchy officialo, 
and a number of lixed annuities, was handed over to "tho king'o use", 89 the phrase went. ${ }^{1}$ Year by yoar it was otated that nothing remainod in the hando of the recolver-gonoral. In the $1530^{\prime}$ 's the oum which rent to the central odminiatration rerled botroen $\$ 8052$ and $\$ 8825$. It reo difidod botreon tho 8B8ignments to the royel household, eixed by the act of 1531,2 and tho treagurer of the chamber who took the rest. Thore 10 no olgn of any changes made in the organisation during the period of Cromell'o oupremacy, except that the disoolution of tho monasteries raised cortain adinistrative diflicultion rhich mill be noticed whon we come to discuse the court of augmentations. The duchy ran smoothly enough. Its gyotom and organisation were simple and efficiont, and in fact camo to serve as models for new departwents. No active interLerenco on Cromell's part can be discoverod; not oron the chenges in the personnel of the duchy ehor any attempt by him to adrance personal Iriends or dependants. 3 As long as tho department did ito work well there was no resoon to interfere. The exchequer, too, ohorg no changes or reforms which wight be attributable to Crowell'o influence. It had loot

1. All this information on the duchy is derived from tho our . viving accounts for the period 1530-1539 (P.R.0. DL 28) $7 / 1-7)$.

2." 22 Henry VII c.18. The sum was 85486.9 .0$.

3. Dachy patronage mas presumably in tho hando of its chancollor (for tho king), but Sir Jilliam Fitzwililam was not the man to oppose Cromtoll's desires had ho wished to appolnt protegés. 
1mensely in importance with the development of tho chamber zachinery; ito revenues and exponditure had beon reducod to cortain rell-delined opheros, and varied littlo yoar by yoar. The amount of money handled in the years 1530-40 shors no appreciable difference from the previous docade. ${ }^{1}$ The exchequer was left to carry on with ito traditional businoso, but anything out of the ordinary in the ray of income or expenditure was dealt with eloerhere. Like Honry VII Cromrell refused to be tied by the cumbrous process and long dezays of the exchequer machinery, and rould not oubmit to tho control mhich its ostablished traditiong provided. He went outaide the exchequer, to the duchy and the chamber, for a model when his enormbus augmentation of the royal revenues zade necessary certain reforme in, and additions to, the inencial organisation.

Cromell made one attempt, hoverer, to relorm a crying abuse in the exchequer machinory. There survives tho droft of a projected act of parliament, corrected and therefore oupervised by him. ${ }^{2}$ He had also foreshadowed it in his memoranda. 3 The bill ras to prevent collectors of revenue - Irom delaying the delivery of the money collected, so as to ase it for their pritate purposes in the interval. It was

1. F.Dietz, Engl.Gor. Fin., "Table II" on P.216. 2. B.L. Harl.1878, 11.22-25 (L.P. X.246[18J).

3. L.P. $x .254$. 
allogod that thoy thoreby dofraudod tho holdoro of governmont annuitien chargod againat thoso rovonuog. Fixod datos woro to be eatablishod by which thoy wore to pay thoir recolpto to tho oentral organisation to which thoy woro rooponolblo. The original dralt referred only to monoy due to 60 to "tho Eynger Colora", and Cromoll insertod a numbor of paosagoo which made theso provisiono applicable to the oxchequer as ro11. Tho sottling days woro to bo 1 Lay and 1 Novombor, on which the recoipto for the half years onding on 25 larch and 29 september respectively roro to bo paid over. Although the draft is in tho form proper to a bill in parliament, it does not appoer ever to have boon introduced there, and it cortainly did not rosult in a atatuto. It 18, hoirovor, an example of Cromell'e reforming activities which aicod at a genoral tightening up of procedure and at making suro that the king recoivod all that was due to him. The relorm ras a necersary one and rould have been wort bonelicial if it had come to anything. In tho eront tho oril grom rorso, and by the end of the century ouch officials somotinos died hope$10881 \mathrm{y}$ in debt to the crown, having lost the royal rovonuoo In tho courso of thoir private opoculationo. 1 So much for tho departmonto which do not roquiro closer

1. C1. Cal.3.P.Dom, Addenda 1566-79, D.46, for the cose of a cuatomer rho did not exploy hio chargo in thio ray, though ho did not faro any tho bottor for hio honooty. Tho lottor Eakes it plein what the usual practico rias. 
attention bocauoo tholr hiotory was not noticocbly influencod by Crombeli's edministration. Tho moro fact of his poroonal control and cuporvision, which appliod to tho oxchoquor and tho duchy as mach as to all departmonts of tho govornmont, is of no interost hero. To aro aftor Cromoll's activo roforma 18 the einencial machinery. It may bo oald at once that ono of his guiding principles 700 a dooiro to govorn frooly, Fithout the chock which a financial agency outaide his control rould have provided. Consonuontly re oholi find him porgonolly ongaged in tho rork of a troasurer, and wo ghall find hit concorned with the chamber which conotituted tho chiof cponding department of the syotom as ho found it. Ho ras at Iirot content to rork through this oyotom while controling It closely, but soon the rovonues which he added to tho royal sncore made it nocoosary to dovelon tho mechinory further. rkere follored that wultiplication of dopartwents which worked well cnough under his poroonal control but mas bound to broak down without his guiding hand. Horover, the Cromellian dorelopment had to happon before the marquese of Hinchostor could rolorm the exchoquer by including in it the now dopartEento of the $1530^{\prime} 8$ and 1540'0. In effect, Finchootor's exchequer, within which tho old exchoquor and tho nor dopartEento largely continued thoir separate existenco, fransloted Cromell's personal control into the tormo of dopartmontal 
organisation. The lord troasurer of tho roformod oxchoquer Tas autoratically in control of the whole of the royal financeo, a pooition which Cromsoll had to conetruct for himeolf out of his various officos and his porsonal standing. 


\section{Cromiral as a Trocouror.}

For a conoidorablo poriod of his oupromacy Crommoll himoolf actod as a troasuror for tho king'r, monoy. Tasks of this kind wero among the first to bo ontmotod to tho now einistor, at a timo whon ho rao atili vary mach a junior Eembor of the government. On 31 Decombor 1530 ho rocolved E13.6.8 "for the king's tomb", 1 and on 7 January 1531 ho paid Eonoy on tho king'o account to an Italian oculptor. 2 Ao "rocoiver-gonoral of attainted lands", in particular tho lando of Molooy's colleger forfoitod by the cordinal's attoindor, ho recoived ronto and paid out sume of noney. 3 Tho post eignificant point is that whon ho was firot givon an ofIice it jerelo 780,88 wo havo soen, an office of little intrinsic 1eportanco, but it $7 a s$ closely linked with tho king's privato Ilnancial adminiatration in an age whon troaoure was comonly 2aid up in the shape of pleto or jerrels. Hio predoceosor, Robert Asadao, was alivo on ner year'a day 1532, 4 and tho torws of the comisolon to Audeloy, Paulot, Bingston, and Tale, who wero appointod to roviom tho royal plate bolore cromell took over, ougge日t thot Cromell's appointrent took place soon after Amadas' death.5 Cromell took the firot

1. Sir Harris Ilicoleg, Privy Purgo, p.101.

2. L.P. $\nabla .32$.

4. IbId. 686 . 3. Ibid. 341,774.

5. Ibid. 939 . 
opportunity, and took it quickly, of acquiring an offloo which gare hit the violblo otatus of a troasurer sor royal rovonuo. As maoter of the king's jomolo Cromoll handlod monoy Lor the king on an extenoivo ocale. Of the anny warrante to him, authorising expendituro, woot addroon hits as neotor of the jorels. It may be oald at once, horrovor, that oome rero eddressed to the king's chiel secretary, and that cromell did not cease personally to act as a royal treasuror oven when he acquired more important offices and a much larger aphere of influence. ${ }^{2}$ The last examples rhich re posooso are given in a paper headed "Loney paid by Mastor Socrotary by theso ij Narrauntteo as lolorith", and ondoroed "A deczaracon of money paid by llaster secrotary to the kingeo vae Lense Aprilis Anno xxrijo Regni Regio Honrici", that is to oay, in April 1536.8 It can thus bo affirmod with cortainty that at least frow Docombor 1530 to April 1536 Cromell acted in person as a treasurer for the king's wonoy. In that period, thereforo, he was hidoelf a part of the machinery of the financial adminiatration.

How important a part rao he? For a conelderable section of the period mentioned the rolume of money pessing through hlo hande can be aecertained; for another, an epproxinate

1. Por the rarranto cl. belori, p.179, $n_{0} l$.

2. P.R.0.SP 1/103, 11.58-9 (L.P. x.598). 
angior 10 posolblo. Thoro exiot four accounte of his for the sonoy ho recoirod and opont in tho king'o gervico. Tho Ilret of these, herealter called A, ootonolbly covered tho tiwo Irom 29 September 1532 to 17 Decombor 1532.1 Thoro had boon a provious account, mado up at Lichaolmas, 2 but it 10 clear from the body of the document that this provious account did not take mattero furthor than 2 April 1532, 3 that is to gay, trelve days belore Cromell'o appointment ao master of the jerols took effect. It is not unlikely that he was rogularly receiving and diobarsing money to the king'o use from tho beginning of 1531, though at that time he was perhaps banding only the revenue from the lands of Folooy's colloger. The existence of an earlier account, closed on 2 April, ouggesta that ho may have taken orer the business of the master of the jerelo on that day, having dram a line under the account of the money he had 80 fir doalt with and otarted a now account to include the not businese. Tho dato of hio patent, - boing the date of ito delivery into chancery, io not, of course; a suro guido to the actual date of appointwent. But whatover wey be surmiged for the firot year of Cromell'o troasurerohip, wo stand on the Iirm basis of fact from April 1532 onwardo.

1. P.R.0. EP 1/72, If.156-7 (L,P. $\nabla .1639$ ), given in App.A(II).

2. Ibld.: "...chargid for the trrerages of the last accompt... ondid at the oaid fleset of paint licholl tharchangoll anno zxtiljto Rogio Honrici vijjul."

3. Ibid.: "oence the Doterminacion of the saide Accomto rihich Ta8 tho Secunde day of Aprill...". 
Tho oecond account (B) corerod tho poriod Irom 22 Norembor 1532 to 11 Uarch 1533, 1 tho third (C) that from 29 soptombor 1532 to 28 June 1533,2 and the fourth (D) that from 2 April 1533 to 2 April 1534.3

It is obvious that thoro is conolderablo ovorlapping, nor mre thoso accounto all of one kind. A and D aro "viors" or enort abotracto mado from tho dotailed accounto, otating olwply totols of rocoipto, paymento, and surplus or doficit, though a contains some other dotajl not otrictly propor to a Vlow of account. $B$ and $C$, on tho other hand, aro dotalled. They analyso both rocoipto and paymento into individual oour ces and destinationo, and for that reason will be of great ase in determining whenco Cromell recoived tho money and to whow he paid it. For es808sing the amount of money that pessed under his hands thoy are neturally 1080 roliablo. A and $D$ were taken Irom finiohed accounto; $B$ and $C$ are drafto, C belng in Cromell's own hand and B cantaining additiono in bis writing. Let us tabulate tho rosulto which thoy pro$\nabla \mathfrak{d e}:^{4}$

1. P.R.O. SP 2/N, 11.114-7 (

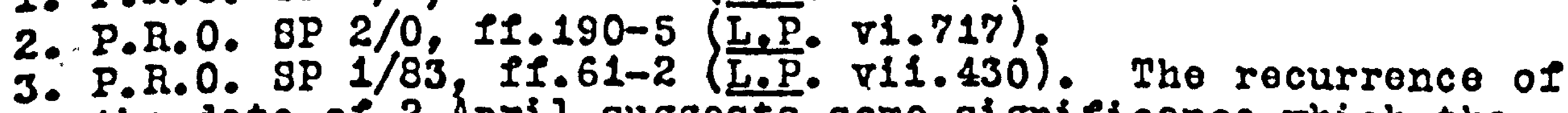
the dete of 2 April suggesto oome olgnificance rhich tho present riter has, horrover, been unable to discover. 4. In this chapter ali aums will normally bo given in pounds oniy. 
Roceipto

2. $(2.4 .1532-17.12 .1532)$

$B_{:}(22.11 .1532-11.3 .1533)$

C $(29.9 .1532-28.7 .1533)$

D. $(2.4 .1533-2.4 .1534)$
$£ 25655$

$\{20567$

$\$ 12496$

$\$ 38504$
Paymonto

$\$ 24606$

$\$ 21240$

$\$ 12332$

$£ 37232$

The threo and a half montho of $B$ (the only account in which pajwents excoed recoiptol are included in tho ton months of c, but the former accounto for $\$ 8000$ moro than the 1attor, though both wention much the some sources of rovenue. Thoy cannot both be right, and unless wo aro propared to suspoct deliberate miostatemonto, a suopolcion for rhich thoro is nelther resoonable ground nor reasonable explanation, wo ohall have to discard $C$ as the lego complete. It 10, wo may ouppose, a lirst draft of an account, writton but nover complotod by Cromrell himself, and baoed on inoufficlent data. Tho . Lact that is is later than $B$ is not resily an obstacle to that interpretation. That it provideo the most convincing oolution of the discrepancy io confirmed by the fact that $D$, accounting for only tro wontho moro than C, gives Ligures throo times as large, and tho goneral roliability of $D$ lo corroborated by tho othor roliablo account, A, which for its ooven and a hall months accounts for a oum roughly oqual in proportion to that givon in $D$.

Let us see, then, what Crowiel''s annual income and expenditure amounted to. If $\triangle$ and $B$ are addod thoy will account 
205: roughly trolvo montho, in which tivo, thoroforo, $\$ 46222$ would havo beon recoived and $\$ 45846$ opent. Thooo aro rathor Ierger oum than those givon in $D$ for tho full yoar onding on 2 April 1534. A chock io provided by the warranto for expendsture Irow which it io possible to arrivo at a minimum Ligure for expenditure for the year onding in April 1535. 1 Irenty-four of thom cover tho yoar after the last surviving account, the earliest boing dated 4 April 1534 and tho last 2 Lay 1535. 2 Thoy provo that during this yoar Cromoll paid et 1008 t $\$ 32407$ for purposes of otate. There is, of courso, no ray of discovoring what proportion of these warrants has beon preservod, ana tho actual oums involvod may havo boon zach largor. However, it is not likoly that wany are lost. rwenty-four warranto for one year, wany of them authorioing the paymont of a large number of 1 tems, 3 and adding up to tho total quotod, rould appoar to loaro a rolativoly omall margin

1. Tho varranto to Cromoll are preserved in throo bundleo: P.R.O. E $101 / 421 / 5$ (calondarod in $L, P . \nabla .825,1052,1237,1314$, $1346,1392,1590,1646,1668,1671) ;$ ibid. $421 / 6$ (33 itomo not calondarad in E.P.); and ibid. $4 \overline{21 / 9}$ (L... $\nabla 1.6,130,131,149$, $170,220,229,283,326)$. Thoro aro al80 a number of 10050 ones: P.R.0. E $101 / 421 / 1$ (L.P. V.341), B.L. Tit.B.i, 11.449-50 (I.P. ix.217), and $80 m 0$ bound with tho atate papors at tho P.R.O. (I.P. V.1119,1215,1370,1645; vi.1057,1367,1508; v11. $137,1557,1564 ;$ Vi11.653; $x .598 ;$ Add. 1013).

2. P.R.0. E 101/421/6, noo. (in chroncological order) $22,52,37$, $34,38,36,39,35,40,41,47,42,43,45,50,46,44,49,48,51,32,33$; and L.P. vii.1557; vili.653.

3. P.R.O. E 101/421/6, no.50 contains 14 itese, no. 45 trolvo, nos. 38 and 49 elevon, nos. 51 and 32 ten, otc. 
zox" Iurthor and unknom oxponditure. Still, it io as woll so bear in wind that we havo hore tho lorest posalblo flguro zor the yoar. Only fourteon warranta survive for tho yoar covered by account $D$, and thoy account for a total expenditure of only 10310.1

Anothor table may now prove usolul, though the figureo bare alroady boon given:

Receipts

Apri1 1532 - Apr11 $1533(A+B)$

Apri1 1533 - Apr11 1534 (D)

April 1534 - April 1535 (warrants)
$\$ 46222$

$\$ 38504$

$-$
Paymonto

245846

137232

$£ 32407$

Theoo Iigures indicate that there may have boen a oteady docreaso in the amount of money handled by Cromrell, which rould not be ourprising in vion of the fact that during theso yoars Cromeil was gathering wore and more of the government of the country into his own hands and 80 , progusably, had 1080 and 1088 tive to act as a treasurer. From April 1534 he was chlof socretary, and it is a good illustration of his abilitios and "energy that even then he managed to attend to auch comparatively minor detallo of adminiotration as a personal trea-. garership intolved. Admittedly the actual handing of the worey wight be done by his servante, such wen as Hilliamson,

$\therefore$ L.:. V1.326,1057,1058,1367,1508; Vi1.137; P.R.0. E 101/421/6, n08: $23,25,24,26,27,29,30,28$. 
Carendiah, and Body who had hla "lottor of attorney...t to roceitre all sume of monoy due to the King's highnosg" in Cromrell's nave, ${ }^{1}$ but as long as Crompell ras accountablo for tho zoney he was a treasurer in lact and not only in name. On the other hand, it is quito posolble that the difforencoo gear by yoar, which aro not exceseively large, way hare boon crusod only by the normal fluctuation of income and expenditare, or by the incompleteness of the soujces on which wo have to rely. Allowing for a reasonable margin of orror we may say that cromell's annual receipte in theoe throe yearo rore zound about 840000 , with the paymonts amounting to littlo 2038. The figures show that not much remained in Cromoll's baids at the ond of each year.

These sums compare well with tho buginese done by the ofher tro great financial departments, the exchoquer and the chamber. Exchequer exponditure for the years onding at Licheolmas 1532, 1533, and 1534 Fas 238935, \$37789, and 237106 respectively. ${ }^{2}$ The exchequer, therefore, diobursed each yoar mach the samo amount as did Cromoll. Horevor, exchequer paymente included assignments of 119394 to the royal household

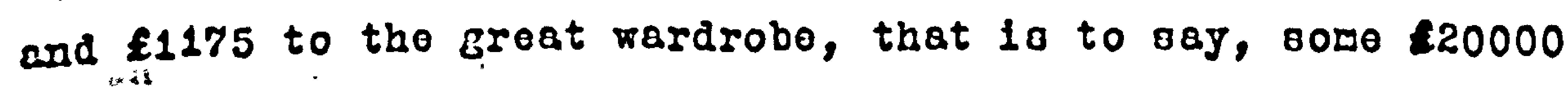
rent to other spending departments. The remainder was largely

1. LeP. 1x.234. Milliam Body was the wan who rendered accounts

A:and $D$ and was therolore probably in charge of this money under Cromell.

2. F.Dletz, Eng.Gor,Fin., p.216. 
zado up of rogular paymento, such as tho oalarioo of exchequer offlclale and other officoro of the crom, or annultios grantod by patont. The only itomo which varied at all woro tho asolgmento on exchequar rovonuo wado by tho king as rowards to collectors of customs or minor oorvants and officialo about the court.1 Cromrell had no ouch regular or "ordinary" oxpendituro, as it was called. As wo shall o00, hio paymonto concornod only extraordinary exponditure which had to bo authorlood by special royal warrant. 2

The treasurer of the chamber, too, had a largo amount of mordinary" payments to mako in rookly, monthly, and quartorly rages, and in ponsions and annuitios. In May 1537 Sir Brian Tulo eotimated these payments as \$40000, and thoy aro likely, In the nature of things, to have beon fairly conatant. 3 His tothl exponditure in the yoar onding uschaolmas 1530, that is before Crombll's rise to importance as troasurer, was $\$ 55270 ;^{4}$

1. Theso Lacts and Ligures aro dorived from tho annual Declaratlons of the Stato of the Treasury" rhich are completo for the years 1530-40, except for tho year onding at ulchaolmas 1535. The documents are, in chronological ordor: P.R. 0 . E 405/109; Ibid.200; B.Lf. Ldd.us 33376; P.R.0.E 405/201; ibid. 202; E 164/69; E 405/203; ibid. 204; ibid. 205. 2. In Fobruary 1534 tho treasurer of the chamber asked that ner thinges ordinary I may haue for paymontos an ordinary rarant, And that for thingos extraordinary I may alvais haue apecial rarantos (B.M. Tit.B.iv., I.117v).

3. P.R.0. SP 60/4, I.78 (L.P. Iil.I.1297): "and myn ordinary paymontes besides casual parrantes be almoot $x I$ u li' by yere."

2. L.P. $_{\text {. }}, \mathrm{g} .321$. It is true thet the expenditure of the treagurer of the chamber had boon mach greater earlier on. 
It wll bo soen that hio "oxtraordinary" or "caoual" paymonta ds not comparo with Cromwoll's. From about 1531 to at loaot sho oarly part of 1536 Cromwoli was a vory important einancial offlclal who adminiotorod conoidorablo sumo and paid tho groater part of the unrocurring, the day-to-day, oxpendituro of the gorernmont. To must turn to tho question from what gources he derived money "to the king's uso", and also what rere tho chiol purposos on which ho opont it.

Dr. Dietz has notod that in 1532 Cromrell "bogan to act 8в a opocial treasurer for now rovenuegn! a romark which prompeed Profeosor Neale to demand a moro detailed discusolon of the adminiotrative oignificanco of this phenomonon, in particular bocause he thought that Cromrell mest have boen oncroaching on the chambor. ${ }^{2}$ Hor Lar that rao tho caso will be soon later; there can, at any rate, bo no doubt from that has alroady boon sald that a considerablo problem of adminlotration ras hldden bohind Dr. Diotz's remark. In one way It definitely misleado, for Diota ras mrong, mo think, in leying the otress on the supposed novelty of the rovenueg

Sir Henry Hyat areragod oror $21,000.000$ in 1522-4, but that ras during a poriod of loreign Far and tho expondituro in question was actually on the war (P.R.O. E 36/221). Tho 88me g008 Lor Sir John Heron's expondituro in 1509-18 $(81,581.503)$, al80 a poriodi.ol maro (B.W. Add.us 21481). His enornous payments in 1502-5 (\$338740) moro in grost part cepitel investments (P.R.O.E 101/413/2). 1. J.Dietz, Eng.Gor.Fin., p.103.

2. J.E.lle8io, in E.H.R., xxovili(1923), p.280. 
adinfingtorod by Cromwoll. Account B giveo thooo oourcoo of incore: ouppressod lande, restitution of temporalitioo, monoy cae by obligation, chains molton, wonoy duo without opocialIlos or bonds (Irom tho jorol-houso), vacation of biohoprico and abboya, tho "mount" of tho lato arcbbiohop of Cantorbury (Trarham), "porformos and loo fformoo", firot fifth of tho woney grantod by tho last convocation (1531), from tho hanapor, irow the king'o colfers, monoy latoly prostod (lont out) by the king, and forfoitod lando and goodo. Account C roposto oowe of these and addo fines for the appropriation of housoo to tho itom headed rostitution of temporalitios in $B, \$ 100$ Lor conduct money given to the king by tho morchant adventurero Lor "malters", 1 lineo for the knighto, and wonoy for "cortain provioions" for the king.

Theso oources ohow plainly that littlo ras inrolvod that could be called not revenue. Cromell drot monoy from land rerenues, being appointod rocoiver-goneral of the lands of tho gappressed monastoriog used to Lound Folsoy's collegos (oupprossed lando), 2 and boing in chargo of tho lando of Rico ap Griflitho (attainted lands).3 This may hovo boon not monoy

1. Naftor - an armod reso8l employed as a convoy", H.E.D. 1. (1928), vol.x, pt.il, p.8c.

2. I.p. V.701. Para.7 is in Cromoll's hand, and the commisolosero montionod in para.9 includo hio confidential oorrant Milliam Brabazon. 


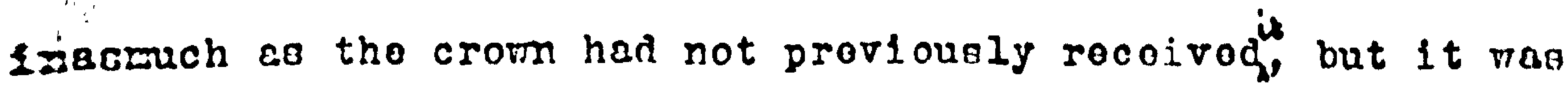
zot a nor kind of rovonue. It ought by righto to havo cono Ezto tho chamber under the torme of the oct vinich dirocted a.l tho revenuo of forfoitod lando, old and nor, into that troacary. 1 Tho monoy dorivod erom vacant 8000 and in fineo for the restitution of terporalitios ras supposed to bo accountod zor beforo the genoral aurvoyoro; 2 the act, horevor, io ailent on the quegtion rhother it ought to have boen paid into tho chamber, as it is also on the oubject of oubsidioo, and ro cen only oay that such axtraordinary and unropoatablo rovonuoo aro almost certabn to have been handlod by the chambor boloro cromell appeared on the ocono. 3 Then they roro acculrod by his, and he is found controlling the revenues of the vacant gees of York and Chestor. 4 Further there rero sums due to bis es waster of the jerrolo ("chaino molten" indicater not oo Euch a rovonuo as a capital expondituro), oums dorivod from cebts to the king (obligationo and prooto) which rould also norzally have boon doalt with by the treasurer of the chambor, 5 e numbor of small and incidental sources of incomo which nood not detain us, heneper money which cromrell might bo oxpected

1. 14 \& 15 Henry VIII c.15 (Btat.Roclm, 11i.229).

2. CI: above, p.164.

3. Cl. AP. liertion in E.H.R., 20xil(1917), pp.3631. Tuke indi- ceted that he got oorething from vacancioo (L.P. Xiv.II.13). 4. L.P. $\nabla .95,237,277$.

5. Cromtroll novor hendied all tho royal dobta, and Tuko continued to concorn hivoolf with a good many. 
:0" expond as clork of tho hanapor oron though it bolonged to the revonue of the troasurer of tho chamber, ${ }^{1}$ and the intorooting itom of money grantod by tho spiritualty.

Thio last point noedo somo discussion. Tho monoy in gueotion mot hevo boon derivod frow tho fine for the nraoEaniro imposod on convocation in 1531, but as that amountod to $\$ 118000$ for both provinceo tho $\$ 242$ accountod for in B can zore been only a small part of the "Birat fifth". Dr. Diotz eeintainod that the rholo of tho fine was paid to Cromell.2 Eorovor, tho original grant stated that the money wao to 80 to the treasuror of the chamber, 3 and tho oxchoquer rias inzorwed likemioo.4 That is more, thio condition ras cartied out. Tuke roferrod to this rovenuo as due to bo paid to his In a letter in rhich ho deplored the remisel on of tho $108 \mathrm{t}$ peyzonto in exchango for the now incoto from lifot iruito and tenths. 5 "The kingoo highnos remyttoth to tho clorglo of the province of Caunterbury $x I$ lI $11^{\prime}$ of the if last paymentoo,

1. So the hanapor accounto ohor, the ourplus continued to go to the trossuror of the chamber (above, p.85). The $\$ 300$ of hanaper money mentioned in account B aro clearly the "profit of tho offico in Thoma Hall's time" phlch Cromell had roceived from the underclork ( $\mathrm{L}_{\text {.P. }} \nabla_{0} 1730$ ), and roprosent a unique case of hanapor wonoy going to Cromroll.

2. F.Dietz, Eng.Gor. Fin., p.227.

3. P.B.O. E $135 / 8 / 37$.

4: P:R.O. E 159/310, Communia, Trinity torm, Rocorda, m.22.

5. B.L. Tit.B.1, I.286 (L.P. Vi1.1490). 
besides a some to the provinco of xorke, And of thoso if last paymentos on $7 a 8$ due at mychelmas last; for lovyo whorof comEyosiono bo oute, contloctours appointed, and tho monoy ouory day norro payable to the particuler colloctoura; and to tho zeneral colloctours after criotenmas; and to tho troasorar of the chambre by our ledy day in lent next... I havo vood sone aftor criotenmas to rocoyuo nom parto, and oo contynualiy 28 it can bo had." From thio doacription it lo moot unlikoly that Cromell ever recolrod a largo part of this line, and tho 2242 rhich he did rocoivo was posoibly tho part of the Iino rooting on clergy with rhom ho had a opocial connection, as Lor instance those of racant 8000 .

It must also be noticod that Crompell revived Henry VII's expedient of enforcing finos for knighthood. This sourco glelded $f 390$ in account $C ; a$ schedulo annexed to $A$ and reciting oure of woney due but not yot collected includeo this point: "flynoo for knyghtes sessid by the oaid Thomas Cromrell Esquiro to tho kingos voo and nat paid, as it apporith by the obligaciono therol examynyd," and the conolderable I1gare of $\$ 2180$ is mentioned. 1 Cromerol's correopondence containo a good doal on this subject in 1533 and $1534 .^{2}$ Peoplo

1. P.R.0. SP 1/72, I.157 (cI. App.A II ). Tho total outatanding ras \$18031 - oovo such factor wight be bohind tho discrepancy betreen accounts $B$ and $C$.

2. L.P. $\nabla 1.425,468,481,514,521,575,607,1160,1178,1260,1360$, 1390, 1659; Vii.80,123,833, 1305, 1662. Cf. 8100 Hall, Chronicle, p.795, to tho offect that Cromwell improvod tho 
wrote to him asking to be excused; they claimed that they had beon sesessed too: high, or pleaded girilar oxcusos on the bebelf of friende and servanto. Eren the princess lfary joined the chorus. 1 Among the papero which apparontly came into Crowell's custody before october 1531 thore was ono doocribed as a copy of "the King's letter to write to knighte", 2 and anong the Remembrances of 1533 occurs the noto "to make a search through the Book of knighte for the names of them who ohall be enclosed in the King's letters". 3 . The machinery for enforcing fines of knighthood seoms to have been rell developed. As Late as Hay 1535 Honry wrote to the sheriff of oxford and ordered him to see to it that the knighte mentioned in the list enclosed either appeared belore cromell ("principal secrotery") to compound for their knighthood or sont up their Iines. 4 The numbers involved were 1argo: in 1533, 1010 persone rere returned as suitable to be made knighte, and 425 had already made out obligatione for paymento to discharge them of the order of knighthood.5 This method of extorting money was certainly not new - it had helped to bring about the fall of Expson and Dudley - and it had alwaye been, and was likely to bo nor, most unpopular. Its revival by Cromell is significant, for its is one more aign that Cromell's accession to

occasion of Anne Boleyn's marriage at Easter 1533 by raising large sumo on "that sessyng of fineg" for knighthood. 1. L.P. Vi.550. 2. L.P. Vii.g23(vii). 3. L,P. Vi.1056(i). 4. L.P. Add.988. 5. Ibid. 877 . 
porrer wao involving tho forernment in a partial roturn to tho policy of Henry VII. Once more money was nooded, for Holooy had dono nothing to koop tho colfors lillod, 1 and for the timo being the nor minioter, in his capacity as troasurer, fos trying to use old and proven mothodo. The suino obtainod, hovorer, were hardly large enough to justify tho rigk of alienating tho gentry and middlo class at a time whon their oupport in parliament bocame esgential.

It rould not, horever, bo corroct to think of cromoli's tressurership as chiolly concornod with the collection of money. All the sourcos which wo have so lar discuesod add up to 1080 than half the monoy which cromell actually roceived. By lar the biggest item in the accounto which are our guideo in this problem is money derived from the royal colfers, that is, from resorves built up in the Toror and posoibly in other royal palaces. Such wonoy accounto for E11034 of the total receipto of B ( $\{20567)$, and for no 1080 than E10991 in C (total: \$12496). Tho subjoct of hor "tho king'o coffers" rere filled and administered is a dark one. It is likely that ourpluses in such depertments as the treasury of the chamber rero not kept there but rore depositod In opecial and highly informal treasuries, called by that

1. F.Dietz, Eng,Gor.Fin., p.102. 
nere. 1 For our prooont purposo it 18 onough to aay that such depooitories oxisted, and that thoy must havo containod quito conolderable reservos. Cromell's expondituro rao, thoroLore, largely of capital, and the true oignificanco of his treasurorship must not bo sought in the colloction of rovonue. It 10 of interost and oomo importance to notico that ho rao actually receiving some monoy which might othorvioo havo gono Into the chamber, though at this time and merely by virtuo - bio being a treasuror Cromoll affectod tho incowo of tho treasurer of the chamber only a littlo. Ho shorod a distinct tendency to acquire any source of revenue, repotitive or occurring only onco, which had no traditional channol by which to reach the government. But 83 he so largely relled on capital reserver this cannot have been hio chiol interest in bis personal treasurership. That mattered to him was clearly the need of hoving sufficiont monoy to meot tho exponditure Fhich fell to his share. To that oxpendituro re must now -tura.

The monoy ras spent on a number of purposog. Account $B$ lists ten groups of paymento, with an oleventh unprovided vith a warginal hoeding, of which these account for the largest gums: buildings at the Toror, costs and remards to ambassadors,

1. Cl. belor, p.28l, n.l. Diets agein only hints at this oubHect (Eng.Gov, Fin., pp.142I.). Cl. Profosoor Hoalo'o roviom (E.H.R., xxrvili, p.280) for a ouggeation that reserach noods to bo made into it. 
and othoro, loans, and in particular f13584 sont north for employment againgt the scoto. It includeo ouch sums as $8 \mathrm{~d}$. Lor "carriago" and 140. 4d. for paper and ink, but thooo aro the only expenseg rhich can be called, in tho phraso of tho Elmo, "nocesec.ry", or curront of1100 oxponditure. 11100 poid Into tho king's coffors rould bo of greator interest if it did not appoar that it mas recoived in bulk, boing rovonues of tho racant soe of Canterbury and the lato archbiahop's "mount", - go that this is not a caso of surplus boing doposited in tho colfero. Howovor, anothor $\$ 1000$ was paid into tho colfere aftor the firot part of tho account had boen wade up. 1 Thore 18 the ugual ftem for the king's tomb which runs through tho Fholo of Cromirell's connection with tho royal financer, and 255 ras opont on oilks and velvets. Account $C$ adds somo inserosting points: buildings at Festminster, tho king's ohipo, \&300 to Cornelys Heyes, tho goldomith, and $\$ 3591$ to creditoro of tho mardrobe. Tronty-four shillings was paid for papor, perchment, ink, and max. Cromell cloarly did not control a large regular office. No wageo wero paid to clerks, and internol expenses rere confined to money spent on vriting

1. There aro a for othor examplon of cromoll paying sums into tho king's colferg (I.P. V.577, 825, 1040,1052,1119), but thoy are all of an early dato, bofore Cromoli rose to importanco. lione of thesforaranto and receipto call him mastor of tho jerelo, all but two being of a date earlior than his appointwent. After ho bocavo a treasurer in the full sonso of tho mord he hardis oror pald money into the colfers. 
Eatorialo. The troaguror of the jorolo naturally had doalinge rith tho king's soldomith, but that was only a omall part of tho total paymenta. Othor itoms rooultod from his connoction Et th tho royal housohold. But Cromrold's main duty lay in looking aftor tho incidontel and unrocurring oxponditure of the government, 38 for inatence the diets of the king's ambessadors or romards givon to foroign ambasaadors, and alno in providing for exceptional paymonts, the consequenco of acts of:high policy. It ras ho tho mainly suppliod sir Goorgo Larson, treasurer of berrick and in charge of the money sont porth for the dofence of tho bordoro. By the ond of 1532 Lamson had rocoivod 24534 from Crombell, 1 and throughout 1533 be ras almays miting for more monoy.2 Lambon's accounts ghor that botroen 14 Soptember 1532 and 17 Juno 1533 he rocelved 223368 of which $£ 20033$ 7as oupplied by Cromtoll, 3 largo Ligures but not so large as the somewhat exaggerated report of 230000 mich Cromell was supposed to have sent north by 11 January 1533.4 Eromoll teo alopo rosponosiblo for linancing the war in Ireland after Fitzgorald'o revolt in 1534. Farrants show that botroen July 1534 and August 1535 he paid out

1. I.P. $\nabla .1670(2)$. The Varranto are ibid. 1590,1671 . Ho Was also getting largo oums through the abbot of St. Wary's, lork, by tho king'o warrant (L.P. Vi.86), but the abbot seews to have been controlled by Cromoli who was appoaled to for a warrant for payment to Lamoon (ibid. 1162) and who sent money through tho abbot (ibid. 217).

2. I. . . 1 . $25,29,51,107,124,185,269,343,553,1162$.

3. P.R.0. SP 2/D, 1.185 (L.P. Vi.664).

4. Ven.C81. i 8.842 . 
221522 for this purposo, not counting rorardo givon to Irioh oflicials moso loyolty was thought opon to purchaoo. Noarly ell thio money ront to Filliam Brabazon, vico-troaguror of Iroland and troasurer at war thoro, and onco ono of crommoll's housohold sorvanto. 1

Altogother, the rarranta are most important ovidenco for the purposes on which the money paosing through Cromoll'o hanas was opont, and they oervo to confirm and augnont the teotimony of the accounts. Thore is not one "domant" rarrant anong them; that is to oay, Cromwell ras not made responoible for regalarly recurring paymonto. The purposes for thich ho paid are numorous and variod, from auch smell itemo as \$33 for South Nalos Iron minos or ton marko for almg to the thousands of pounde opent on military affairo in Iroland and tho Scottion Garcher. Diots and post money to ambassadors aro one largo group of payments, and it is possibly of somo significance that the ambasoadors pald by the mastor of tho jowelo roro particalariy those who wont to Germany and tho Luthoran princeo,

1.P.R.0.E 101/421/6, no0.33,35,36,39,41,43; L.P. Vii1.653; 12.217. In Lay 1535 Brabazon's accounts ohow a rocolpt of E34628 Irom England (L.P. V111.788). Ho may not havo had ali thio Irom Cromoli; anothor of hio accounte (L.P. Xi.934, octobor 1536), which covers probably only tho yoar onding Lichaelwas 1536, shors that Crontroll was reoponsible for $\$ 13718$ out of a total of $\$ 35692$. The largest singlo contributor was the troagurer of f1rot eruits, who horever did not exist during tho poriod of tho firot account.

2: IiP. V.1215. 3. Ibid. 1346. 
that 1 o thooo who woro purouing what ras moro spocifically Crowell'o orm policy.1 Rorrarde given by the king both to Loreign ambasoadors and to his orm servanto account for another conoiderable number of entries. ${ }^{2}$ Frequent payments mere made to Milliam Gonoon, surveyor of the king's ohipg, for the navy; Irom October 1533 to Decombor 1534 Gonson gavo twonty receipte for a total of $\mathbf{4 1 9 5 . 3}$ Cromoll also ouppliod the housohold of Katharino of Aragon, 4 adrancod largo oums to the cofferer of the housohold, 5 paid the creditore of the groat rardrobe, 6 and paid the solaries of the king's logal officoro, tho judges and king's serjeants.?

1. E.g., Thomas Legh (L.P. V.1646; Vii.137; P.R.O. E 101/421/6, no.38); Hoath and Pagot (L.P. Vii.137); Chriatophor Hount (L.P. ix.217; P.R.0. E 1017421/6, no.27); Cavendish (ibid., no.49); Foxe, bishop of Heroford (L.P. ix.217). Horover, Cromell also paia other ambasaadorg, eapecially later when he ras in complete control of the government: Hackett (with the emperor), Rochelord and Gardinor in France, and Lord Filliam Howard in Scotland (P.R.O. E 101/421/6, nos.27,32, 38; L.P. ix.217).

2. A fert examples rill shor their catholic range: John de Lenope, senator of Lubeck (L.P. Vif.1557), "one that brought borstares" from the king of France (L.P. Viii.653), Robert groom of the chamber to the duke of Norfolk (P.R.O. E 101) 421/6, no.24), John Alleyn, master of the rolls in Ireland (ibid., no.27), Thomas orgall, for "rritinges concorning our causes" (ibid;, no.30), the orator of the count palatine (ibid. no.28), for bringing pirates from Grinsby to tho Totrer (ibid., no.22), the ambasadors Irom Hamburg and Lubeck vith their "lamilies" (ibid., no.47), Thomas Derby and Thomaa Mriothosley, clerirs of tho signot (ibid., no.42).

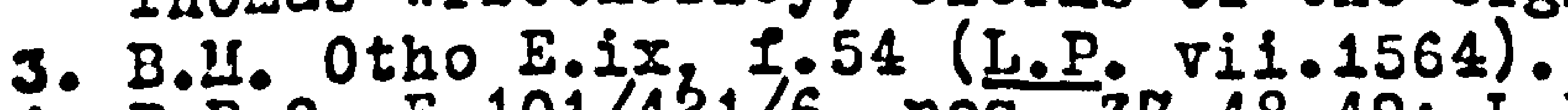

4. P.R.0. E $101 / 421 / 6$, nos. $37,48,49$; L.P. Vii.1557; 1x. 217.

5. D.R.O. E 201/421/6, no.26.

6. Ibid., nos.25,50.

7. Ib1d., nos.34,48; L.P. Vii.1557; x.598. 
Enough has beon oaid, though tho dotail is but a amall part of what might bo producod from tho warranta, to ohow that an offlco which handled conoidorablo oums of monoy, rocoirod an Income from both ner sources and the royal rosorvoo, and corerod such a varied and important soction of tho government'o exponditure, was a financiol dopartmont of tho firot order. Not content with "dovioing Irosh sourcos of rovonue", 1 and with doubling the incomo of tho crom, ${ }^{2}$ cromell poroonally acted for at loagt four yoars as a treasurar and paymastor. It is difficult to say to what extont he continued to do so after the ovidenco of accounto ana rarrants gives out, but tho very absenco of the latter in parthcular is oignificant. On the whole it secms that he gave up direct action when his general duties, as secretary and lord privy seal, became too large to allow him to carry out the samo amount of detallod Fork at a lower lovel. In this connection it is of groat importance that the last clear evidenco of his troasurorahip 18 of April 1536.3 It was cortainly not lator than thio dato that he ourrendored his patont of tho mastership of tho jorols, the.offico then being grantod jointly to him and John Williams. 4 Cromoll at1llidrer part of his salary, but he coased to carry out the dutios of tho office rhich had given him tho visible

1. H.A.I.Figher, Pol.Higt., V.447.

2. F.DIetz, Eng.GOV.Fin., p.140.

3. Above, p.175.

1. Lbore, pD.63f. 
otatus of a treasurer. Cromoll continuod to oxercioo a close and detalled control ovor the Inances of tho country, but thore is overy roason to ouppose that the absonco of any oridence ofter 1536 roflects tho truo pooition: ho rao no longer activo as a troaourer actually handling tho king's woney. There are indications that during the crisio of the pilgrimago of grace ho once more occupiod himsolf with tho detailed work of providing monoy for the arinios sent againot tho sobelo, but there, too, ho sooms to hero left the actuel collection, convoying, and disbursoment to othor financial officielo. 1 The lord privy seal originatod and controlled all Eosoures, but ho did not personally adminiotor thom.

Not that his porsonal treasurorohip ras merely a quootion of administration under tho control of comoono elso. From euch evidenco as ourvives it seems reasonable to oupposo that his paymonto mere normally authorisod or covored by a warrant ander the oignet and sign manual. There may havo beon occesions on which crowrell paid money oither by the king's vorbal instmactions or complotely on his orm authority, without afterrardo getting a witton command to cover himself, but in tho nature of thingo such transactions have left no trace. It ig on the rhole unlikely that Cromell ghould havo acted in this 1. L.P. zi. $624,638,640,658,660-1,724,768-70,791,801,822,829$, $\therefore 834,842,911,958,965,1106,1124,1163$; xi1.I.683; Add.1130.

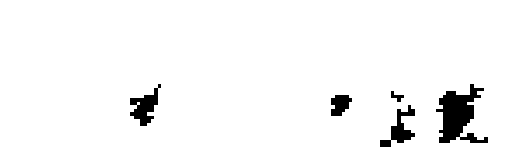


ray; it could bo dangorous whon thingo ront wrong, and it was unnocosoary, for as ro ohall soo ho could alwayo obtain tho roquieito warranto. Thooo documento rould bo moro holpful In oolving the question of Crowroll's authority ao troasurer 12 thoy rore not complotoly formal. Thoir phrasing is no gaido to the importance of the porson addresood, 1 though if ono acceptod them at their faco value ono rould have to think of Cromell doing no more than pay whon ordered.

Horrever, thingo noro far othorriso. That Cromroll ao often as not paid money on his own initiative and for purposes of rhich be alono wes the judgo io proved by the ovidonce that bo Irequently obtained rarrants for paymento already mado. ntem, to cause Farrantos to bo dramen for auche monoy as is nonly laid ort by mo for tho king," runs a typical noto in ono of hio listo of "Reriembrances", 2 and thore aro wany oimilar aemoranda betrioen February 1533 and April 1,534.3 Perhapo tho wost rovealing entry reads: "To know what things thot I do 1eck resrant for, and to cause a rarrant to bo made theroos to 81gn."4 Indopendanco of action disguised as obodionco to orderg could hardly go lurther. Somotimes ho rould apparently

1. By far the Eajority addroso him as mastor of the jorrols; many combine this office rith another, such as councillor or chief gecrotary. There aro aloo oome addreosing him in the latter character only.

2. B.L. Tit.B.i, $1.427 \nabla$ (I,P. Vii.48[1]).

3. L.P. Vi.150,284, 1370; Vii.48,257,583.

4: 
draft his orm varrants, 1 though no doubt that part of tho rork rao ugually left to a clerk. Littlo can be doducod Irom tho dateo of varranto. On 6 July 1533 Cromell was authoriced to pay 2000 to the cofferor of the hougohold, 2 and tho actual transaction is recordod as having takon placo on $18 \mathrm{Jusy}^{3}$ but whether the firnt date roprosents the actual date of issue or a case of backdating cannot be said Lor certain. On 6 January 1533 Sir George Larroon acknoriledged to Crommell the receipt of $\$ 2034.13 .4,4$ a oum for rinich the varrant is dated 28 Docomber 1532.5 Again, the ebsence of any certainty about the true date of iegue rakes the case inconclusive. There is no other example to which eren so unsatiofactory a tost can be applied. It will be necessary to confine ourselves to the guarded otatement that crowell certainly paid wany aumo for which he obtained warrante later, a lact which shows him to havo been more than - oizply a subordinato paymaster; while at other timeo he may nave paid on warrante in hand. On the whole it is roasonable to suppose that he pursued the latter couroe more often at tho beginning of his career, before he fully established his supremecy in the governwent. The first ourviving warrant to him strongly auggests that the recipiento, came to cromell with

1. P.R.O. SP 1/78, 11.243-4 (L.P. Vi.1057).

2. P.R.0. E $101 / 421 / 6$, no.26.

3. Ibid., no.(3). 4. E.P. V1.25. 
the rerrant in thoir hondo. 1 At any rato, it mut not bo concludod that Cromill $7 a$ merely a subordinato agont bocauso tho rarrants addroosod to him lollowed ostabliahod form and roro phrased in words of command.

Thus during the poriod of his poraonel troasurership Cromell mado himsolf the contral official on the oponding cide of tho financial adminiotration. Ho pao not groatly omployed, or perhape interested, in the colloction of rovenue in bis orn hando. In any case, the fact that ho novor croated a proporly organised office but $\nabla 8 \theta$ content to rely on tho grell etelf of the jerrol-house, who vere employod oololy in Eatters connected with the king'o jowelo and plate, and on hio orn household made it impossible for him to concorn himself wish that taok. Ho loft it to tho exchoquer and chamber Eechineries to bring in the revenues, himsolf collecting but a fer and those such as needed no groat dopartment to admin18ter. His main concern as a treacurer was the paymont of extraordinary and casuel exponses, in other rordo, payments that were the direct result of, and closely connected with,

1. P.R.0. E 101/421/1 (L.P. V.341). CI. App.A(III). This marrant of $18 \mathrm{July} 1532$ io addrosood to Cromrell oimply ao "our trusty and relbiloued soruaunt", though ho had by thon boen mastor of the jerrolg for throo montho. It way bo oignieicant that the woney in question had nothing to do the master of the jerrols, but as thore io no reason to think that Crowrell kept apart the monoy which came to him in his difforent capacitios nothing can bo mado of thio adminiotratively. 
the higher ophoros of government activity. He rishod to bo able to omploy ambessadore, to build the king's palacos, and to provido for the defoty of the roalm by land and 800 , without eoing to other officials for the nocosoary monoy. By the reforms of Henry VII, such money was norwally provided and adafnioterod by the treasuror of the chamber. Howoror, the charber was essentially the most intimate part of the royal bousehold, and its peculiar position in the adminiotration of the realm ras compatible only with a dogroo of porsonal govorngent by the king to which Henry VIII did not riso. Ito troagurer $r 8 s$ too much the king's officer, too little a tool of Cromoll's making or for Cromoll's use, and the minister therofore took into his orm hande the administration of largo sums of money. True, cromell started his career in office fith a purely financial post, and it might theroforo be thought that tho adminietration of money had come firot and the inIluence on policy later. But Cromell was a nember of the council for over a year before he became a treasurer, and at ro time did he allow his duties as a treasuror to distract nit Irou the more important task of helping to ohape the king's policy. For hiw, administration and policy wont hand in hand, and he gar in his treasurership mainly a means of making hio control of both more direct, moro effective, and woro efficient. 
III, Cromeli and the Chamber.

Tho changes which Honry VII mado in tho financial machibery, and which vore confirmod by parliament in tho oarly yoare of Henry VIII, ${ }^{1}$ have boon deacribed in an article which takes the subject dorn to $1529 .^{2}$ Thoy rosulted in the ostabliohmont of the chamber as the loadine financial agoncy, more izportant becaueo more flexible than the oxchequer. Ito main otrength lay in its close asoociation with king and gorernment; the troasurer of the chamber accounted oithor to the king him-. self or to the king's personal servante, the general eurvoyora, and ras not subject to the cumbersome syotem of checko and eafeguarde which made the exchequer unsuited to the demando of the modern state. Wore and yore busineso vao, thereloro, pegsed on to the chamber. Its revonues, which fundemontally conoisted of certain spocified royal landa, camo to include lay and clerical subsidies, ${ }^{3}$ and ouch extraordinary incomo ao Dolsey's loans.4 Its expenditure spread to cover all the imediate neede of the government, the payment of lees, diets, and rowards to the king's sorvante and officoro and to foroign anbegsadors, the upkeep of the defonces of the kingdom, and

1. Statutoo 6 Henry VIII c.24, 7. Henry VIII c.7, 14 \& 15 Henry VIII C.15.

2. Ap. Sertion, "The King'o Chambor under the early Tudoro," 2. A.H.R., Xixii(1917), pp.34811.

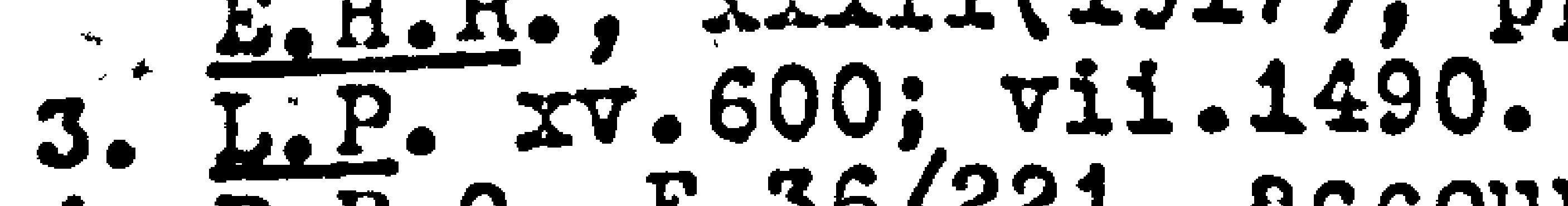

3. P.R.O. E 36/221, account of Sir Henry Hyat, treasurer of tho chamber, for 14 Honry VIII. 
the like. ${ }^{1}$ The chamber handlod very largo ourn, much largor then those passing through any othor dopartmont. Botwoon Ifichaolmas 1502 and Nichoolma 1,505 the troaguror of tho chamber received $\$ 361469$ and expondod $\$ 338740,2$ and a oimilar turnover of about $\$ 120000$ a year is indicated by tho sum of \$1,581503 spent betrio on Liay 1509 and April 1518.3 In fact, there appeare to have been a olight but stocdy incrorse in tho business of the treasurer of the chamber during tho first half of Henry VIII's reign.

From April 1528 to his derth in October 1545, tho office of treasurer of the chamber ves held by Sir Brien Tuxe, a looding civil oervant of the tive, tho combined its duties rith those of the French secrotary and, until 1539, of tho clerix of parliament. 4 Unfortunately tho matorial in rhich his administration can be studiod is not so satisfactory as that for his predecessors, though it is rathor nore lively. STe possess tro of his books of payments, one for Octobor 1528 to Lay 1531, and the other for February 1538 to June 1541,5

1. Detaila are given by A.P.Nerton, loc.cit., pp.3641f.

2. P.R.O. E $101 / 413 / 2$ (iii).

3. B.i. Add.ins 21481, 1.288 .

4. The geliont points of Muke's career are given by A.F.poliard in D.B., ., xix.1222a-1223日. Ile is thore mistakonly callod troaguror of the houcohold instead of the chamber. For the fact that ho ceased to be clork of parliament in 1539 , $\mathrm{cl}$. banaper account P.R.0. E 101/223/6.

5. P.H.O. E 101/420/11 and B.1. Arundel us 97. Both are fuliy calondared in L.P. 
and somo ocattorod partial accounta, acquittancos, and rarranto, as woll as a conoidorablo nuwber of lettora pritton by him Irom which information about the rorking of tho offico and about its financos can bo obtainod. From thoso souroos a tolerably cloar picture can bo mado, though it is ag roll to rozomber that in the absonco of any comploto accounts of rocoipto zany conclusions must be olightly tontative.

The firgt thing which emerges from Tuks's accounts of hio paymento is that thoy docroasod quito otartingly in tho ton years botwoon 1529 and 1539. Thile E55270 was spont by him In the full year ending at ifichaolmas 1530, only about $\$ 33000$ Fas opent in a similar poriod ending in 1539, and about $\$ 40000$ a jear lator. 1 A doclino of business erom thirty to forty percent in ton joars reans a sorious doclino in the importanco of the office, the wore so as tho goneral expenditure of the govermment had considerably incroased.2 similar ovidonco can bo found in a fragment of an account for tho last yoar of tho troasurorohip of tho chamber in ito old form, bofore it

1. The first liguro io given in L.P. $\nabla$, p.321. For tho later years thckccountakre miosing Ior septembor (monthly) and Iflchaelmas (quarterly and half-yoarly) totals, but tho figures for the throe-quarters of a year onding on 30 Juno aro E24450 and \$30406 reopoctively. Fhon proportionatoly upgraded thoy givo the totalo in the text. That ouch upgrading is permisaible is ohown by tho fact that tho oxpondituro for the threo-quarters of a yoar ending on 30 June 1530 rao 42163, noar enough throe quartors of tho sum spont in tho vhole year.

2. F.Dietz, Eng.Gor.Fin., pp.1401L. 
mes morgod rith the troasurorghip of tho norly ootabliohod court of genoral ourvoyoro. In tho throo months of July, Lugust, and Soptombor 1541 Tako rocolvod 6838 and opent 26716. 1 If theso oums may bo takon as ropresontative of an ordinary quartor, totalo in the neighbourhood of only 125000 aro arrived at, a far cry indeod from the six-figuro totalo of tho dayo of Sir John Horon and Sir Honry Wyat. Thingo bocaso even worse under Tuko's ouccossors. In the thirtoon wontho onding in Warch 1547 Sir William Carondion rocoirod $\$ 7896$ and paid $\$ 5377,2$ and in Docombor 1548 ho told the comEisolonero appointod to invostigato tho office of tho troagurer of the chamber that his yoarly income for tho tro yearo past had boon \$4737, that tho offlce ras in dobt to tho tune of $\$ 14000$ but that $\$ 28991$ vas. oring to it, and that hio normal pajments exclusive of extraordinary rerranto amounted to E25200 a joar. 3 As a reoult a cortain improvement soomo to nare taken place noxt year, though exponditure otill oxcoodod income, 4 but tho office, like the rost of tho financial adminiotration of the country, wao clearly in a bad way, and it causes no surprise to lind it reduced to ito original function of pare household dutios by tho exchequor reforms of Mary'o

1. B.H. Rojnl MS 7.F.xiv, 1.77.

2. Prevelyan Paperg, il.5.

3. IbId., 1p.11I.

4. Ibid , pp.13,34: roceipto (1 0ctobor 1548 - 30 September $\frac{1549}{154}$ - \$16868; payments for tho oame period - \$18036. 
colgn. 1 Tho collapso of tho oyotom rao no doubt duo to thoso causoo which throw the whole of tho royal financos into conzusion aftor Cromwell's fall: incroasod oxponditure, lack of Fioion and ability, and incroasing corruption. Howovor, tho docline of tho chamber began during the yoaro of Cromrell'a oupremacy.

Tuke'o letters to Cromrell preaent a picture of conotant difficultioo. Ho ras alrays appoaling for funde. "Sir," ho vrote on 19 December 1534, "I assure you as I wol angwer at

1. Thaugh this is not the place to follor tho hiatory of the treasurer of the chamber to its ond, a brief indication of rhat happonoa to tho office undor lary and Elizaboth muat bo given. The Declared Accounts in the Pipo Offico givo a auficiently clear picture. The first of thom (I.R.O. E 351) 541, m.11f.) recites a nit of privy soal, datod 14 Decombor 1557, ordering the excheruer to pay to the chamber $\$ 3000$ for the payment of rages to all sorts of minor household and court officials. The treasuror opent only $\$ 3032$ that yoar, firs clearly thorefore on purposea listed in tho privy soal. Then account of Elizaboth's roign covors tro yoars (1bid., m.71f.), With receipto of $\$ 15827$ made up from revonue paid in by tho exchequer, court of wardo, the duchies of Lancastor and CornFall, the hanaper, and the treasurer of the household. Tho pajmenta (\$15130) are classiliod as follows: alms, rerards ordinary, $\mathcal{L}$ es and rages, annuitiog by rarrants dormant, "postinge chardgog" by marrant of the quoen or privy council, rewards, making ready of the queen's houser, gardens, wossengors, and payments by the treasurer as mooter of the posts. Fith the exception of paymonts authorised by rarrant these correspond to Tuke's "ordinery" oxpenses, and the exception is a very omall one. The state of thinge remained the oame throughout tho roign. Tho office had boon fully organised, its incomo being derivod Irom fixod allocations Irors cortain sourcos, and ito paymonto being confined chielly to vages in tho housohold and recurront annuitios. It no langer sorvod ovon partially as a oponding dopartment for the dayto-day expendituro of the government. \{Cf. aloo F.Dietz, The Exchequer in Elizabeth's Roign, p.65). 
ay poril that torardos ifj $U$ li' that I nodos mat pay thio crlatonaa for wageo and for reriardoo for nowyoroo giftoo, bosidos all other ordynary paymentes notro duo, amounting to aswocho, I haue not in hy handeo 111 '... No I heuo don moro than ong, I must endanger my self for my furniture... I thought to heue bosought you to londe me is Ii' til warcho, And yot I zust havo mado shyft for 4 Ii' or if besides." 1 and again, on 28 Warch 1537: "I shal not havo of monoy asoignod to my recelpt $x x \mathrm{~A} I i$ ' by yore, and myn ordinary paymentes besidos casual rarrantes be almost $x 1 \mathrm{LI}$ l' by yore."2 on $18 \mathrm{JuIy}$ 1537: "Ly Lorde, I shal not nede to aduertige your Lordahip hore sklendorly I at this tyme and and of long season am liko to be furnished of the kinges money." 3 In letter after lettor be appealod for the Fifteenth and Tenth granted in 1534, which had alrays "come from the tollers of the receipt to the troa-

1. P.R.0. SP 1/87, 1.133 (L.P. Vii.1556);

2. P.R.0.SP $60 / 4,1.78$ (L.P. Xii.I.1297). $£ 40000$ vias an ororestimate; we have soon that his total expenditure by this tiwe hardly reached that figure. Tulse was given to budgeting too carefully. On 4 August 1539 he rrote: "August vageo almost iifj C li', and then in the nek nychelwas rages litel lak of xxilij $C$ li'. This, my lordo, is bosidos al othor Terrantes, and bosides ambassadours diettos and al other myn ordinaries" (P.R.0.SP 1/153, 1.9; L.P. Iiv.II.13). In fact he paid f311 in rages that August (B.M. Arundel us 97, 11 . 86-87v). At lij chaolmas ho paid f808 in quarter rages (ibid., 11.917-937); the half-joar's rages aro lost but may be ostimated from the items preserved for Larch and Septombor 1538 and for Larch 1539 at about $\$ 360-370$.

3. P.P.0. SP 1/123, 1.10 (L.P. Xii.II.276). 
oorer of tho chambren. 1 The troublo nas that ho wao not Eotting his accuatomed rovonues, and in suguet 1539 ho compilod a lone liat of complainto and difficultion in ordor to cequaint Cromoll with the truo position. 2 Ho had rocoirod nothing from the oxchocuor for a year, and aogignmonts bolore that time had always beon esrmarkod by Cromell for some apocific purpose; ${ }^{3}$ his incore from the hanapor - "rihiche ras ront to be to mo a good shoteanker in suche vacacion tymes" nod suffered the same lato; ho had large oxtra oxpenditure for fortifications and the like; and ho had lost a numbor of good sources of income: the assignments to the household ("chaungod from deoperate paymenteo to the best that I had") now rent directly from the exchequer to the cofferer of the bousehold, "al the eschequer money cometh nowe to other handed", purchased lands contributed to the court of augmentations, forLeited lands to the treasurer of first fruits and tentho, and

1. Ibid. It is cloar, thoroforo, that subsidjos vero colloctod by the exchequer but expended through the cherber, a point of oome interest in adminictretion. C1. 0.100 P.R.0. SP 1/ $128,1.54$ (L.P. Xiii. T.47): "There nodeth no grote dioputecion thither this $x \mathrm{th}$ ohuide be poid to Eyn office, soing that first it is the veray ordre and couroe It ehuldre bo bo, and socondily, It is necosoary." CI. further L.P. xili.I. 309,1288 .

2. P.R.O. SP 1/153, 1P.9-10 (L.P. Xiv.II.13).

3. Exchequer aseignmonts to the chamber, Elven in the "Declarations of the state of the Troaoury", are a mizod lot from which no ueoful etstistica can be obtained. These aro the Iigures for the poriod 1529-40, except for the yoar 1534-5 Thich is misging: $\$ 464, £ 880, \$ 3796, \$ 4554, \$ 2595, \$ 1342$, 689, \$439, \$1005, \$113. 
Eoney from vacant 8000 and abbeyo was no longer coming to the charber. A good doal of money had at ono tiro boon obtainod from dobts owing to the king, but thoro ran not much moro to bo had from that sourco; ${ }^{1}$ ho had oxpleinod in er. onrler letter that "the grote detteg the. bo leviable be for the most of thor paid or otallod to orsal yeroly poymontor, and tho nor: dettos, sone I reo officer, be but vpon wardes and lyuoreyo, payablo by smal somes; whicho though they come in wol do nouertholes amounte to no notable oomed. The grote detted arose vpon lones of money and licences wherof forto or none bave pasoed sons I ras officer. And I have cut thom ghort that wer afore, ffor I have anowerd and levyed thlo $x$ yer that I bavo ben the kinges officer ferro above $x$ L marc' by yero of his gracos detteo, whiche is C If marc'; and I on suro, to the emperour, to the frenche king, to the erencho quene deceaced, and ay lorde of Suffolk, to the staple, to my lorde of liorthumberlande, the lorde Audelay, \& other, there is forre above C I Ii' of dettes discharged in tyme by rarant, for the whicho the kinges highnes is otherrite recompenced or agrede with. And many reuenues that I ves wont to recegue bo gon, som in to other courtes, som otherrise by gift or exchange of

1. Betroen 17 Docember 1536 and 10 tiovomber 1537 Tuke rocoived a minimum of \$1036 from "stallod" dobto, as a filo of rocoipts showg (P.R.0.E 101/422/6); for tho yoar ending at Iichaolwas 1542, his incomo from rias $\$ 2348$ (ibid. $423 / 5$ ). debte 
Landoc." 1

That ras tho burden of his oong: thoro was not onough zoney coming in to dofray tho paymento charged againot his office, though he rould not wind if hio oxponoon roro cut dorn elong rith his income, 2 and the reason for this otato of afIairo was that auch of hio revonuo had disappoarod, oithor bocauso it could not be repoatod, like tho dobto ho had rocoverod, or bocarse it had beon oquandered, Iike tho lando rhich tho king had givon array, or becauso it had gono to othor troasurors. This lest is to uo the most interooting and tho moot important reason. Nore plainly than anything olse it ohowo the Leto of the treasurorship of the chombor. Betreen 1485 end 1529 this office had acquired over larger sources of rerenue, gathering in both nor and old, but in the poriod of Cromel1'o supromacy it ras deprivod of many of theoo in the courge of a number of administrativo reforms which are assoclatod rith the setting up of the new financial dopartmento, and which rere the impediato result of the extension of the king'e income which Cromell carried out at the expenso of tho church. 3 Cortain signs of such a policy had boen apparent

1. P.R.0. SP 1/133, 1.245 (L.P. I11i.I.128E).

2. P.R.0. SP 1/128, 1.54 (L.P. X1ii.I.47): "Being I almaio beot contented rith lest recoipted, so my paymentes bo cut of accordingly," and P.R.0. SP 1/129, L.28 (L.P. xiii.I.249): "I an in no doubt but that your Lordohip by your groto misedomo rol. take ordre, So 08 I bo chargod as I ohal recoyue."

3. Profeseor llerton claimed that the poriod betroon 1487 and 1553 ras "divided naturally into tro portiono by the groat 
in Crompoll's peroonal troagurorahip, ihon somo rovonuos that of ther had or ought to havo gono to tho charbor roro divortod Irom it. During the yoars that followod tho apollart on of tho church Cromoll aloo concerned himsolf with tho problom of Inancial adminiotration ao diotinct frow financo. Among othor moasurog ho aloo attonded to tho troasurorohip of tho chamber which omergod from hig treatmont shorn af many of ita extraordinary revonueo and deprivod of ito oomanding pogition In the financial syotom.

In thia Cromell rent againat tho poliey of Honry VII and Jolooy, both of whom had boen contont to roly on tho chambor zachinery, oren for the administration of tho ronoy opont in costly 78ro. 1 To have alroady $800 \mathrm{~m}$ that, as mastor of the jomelo, Cromrell had taken on a good proportion of tho axtraordinary expenditure of the govornment fhich had unt1l thon bocn handiod by the chambor. Ho did not by any moans acquiro oll of it; if anything, tho itemo of payments by the treasuror of tho chamber aro more numerous and varied in 1538-41 than 1n 1528-31, even though the total opent is smaller. Cromell bad also cut a little ray into chamber rovonuos. Fo haro triod

"Inancial woasuros of Honry VIII in $1529 "$ (E.H.R., xxxil, p.350). I am at a 1080 to underatand what woaguraa are here reforred to. Thoro cortainly ras a departuro aron oarlior policy resulting in lar-roaching administrativo changos, but that did not como until tho now revenued noro asoignod to tho crom in 1534-5 and had nothing to do rith Honry himsolf. 1. For Molegy's policy cI. A.F.Pollard, Folgey, pp.1291. 
to explain thio by arguing that ho noodod a financial agonoy wore imodiatoly under his own control, in ordor to bo froo Irom woney difficultios in the execution of his pollcy. That, horrovor, is not onough to account for tho groat adminiotrativo changer and innorationo in tho fiold of linanco that took place in the 1530'0. Of thoso changer tho doclino of tho chamber rias ono and tho sotting up of now dopartmonto anothor. Tho trio, horrovor, wont hand in hand; nor did tho - chamber escapo the implications of a policy vhich mado for organised departmonto rathor than informal arrangemonta within tho household.

The riso of tho troasurer of tho chambor was due to hio being a housohold officor subject to tho king'o control and personal authority only. Honry JI repeatod tho procese, so comon in medieval administration, of using a housohold offico for purposos of national gorornmont, thus onabling himsolf to Eororn wore efficiontly. In a ray, ho wao roviving rather than invonting, for chambor financo had boon a diotinctivo Leaturo of the reigno of Edrard II and Edrard III. 1 Tho Tudor famber syotew, horrovor, secure the king's personal governwent against opposition, but to incresse officioncy; it was a puroly adminiatrativo dorelopment pithout political oignificanco. Fhen the king's

1. Tout, Chaptors, 11.207,32311.; iv.2381f. 
Lmediate oupervioion wao nithdram, boing roplacod by a toro Lormalisod control of lasuos and audito, whon moroovor buolneso increased so enormougly that the intimate and informal relationohip of king and troasuror bocamo incroasingly dificult, ${ }^{1}$ tho chamber shorred signo of folloming tho common modieral trend of household offices, that is, to develop into an oxtra-curial dopartment of otate. The treasurer of the chamber nover actually "rent out of court", but tho reason for this was that his career ras doliberatoly cut short and national finance was handed back to the old national machinory, tho oxchequer.

The first oigns of a nor and more definite otatus for the office rore given in the statutes of the boginning of Henry VIII's roign. The proamble of 6 Henry VIII c.24 otated that tho practice of Henry VII's timo, whon the receivors of crom property prid their money diroctly into the chamber and accounted by rord of wouth to the king or his servanto, lacked ezchequer approval and might therefore load to trouble for these oradors of exchequer control. ${ }^{2}$ The act, therefore, appointed John Horon by namo to be treasurer of the kind's charbor, raking him accountablo to tho king only, and also eppointed two general survoyors of the king's lando with an

1. C1. A.P.Nerton, in E,H.R., $x x x i 1(1917)$, pp.3681. 2: Stat,Roaim., 11 .145. 
ootablikhment of clerk, moooongor, and uohor, ao a dopartmont of audit. 1 The intorprotation of tho etatuto vas comraltod to all or four of tho folloifing: tho chancollor, tho archbibhop of York, tho lord troasuror, lora privy ooal, otorard of the hougohold, chasborlain of tho housonold, king's socretarj, mastor of tho rollo, and tho two chiof justicos. Inis act, and thoso confirming or slightly awending it in tho course of the reign, 2 put tho position of the chamber on a logal bagis whore it had so far rootod on tho king'o rill only, but by dofining tho act nocoosarily circumocribed and oot boundo to furthor devolopmont. This nas not intendod and mas not the immodiate offect; it has alroady boon noticed that tho busineso of the chamber increased considerably during the first half of the roign, and the troasuror continuod to acquire ner and irregular rovenues as, for inotanoo, Noloey's Lorced loans. Horrover, on the ono hand, his duties and powors had been put on rocord, and on tho othor, tho ultimato control over him had been deputod to a committoc of tho council by a young king eager to oscapo tho dradgery of govornwont. The beginning had boon made of dovoloping tho chambor into an organised department of otato.

During Holsoy's rulo no offoctive reform of the machinory

1. Ibid., pp.1491.

2. 7 Honry VIII c.7, 14 \& 15 Honry VIII 0.15. 
wad undertaken. In tho experioncod hande of John floron tho chamber ran itsolf, until tho king apparontly roolisod that bo rog no longer exercising ouficiont control ovor tho govorncont, and a papor vao dram up, for or by Folnoy, conoorning roforms in a number of dopartmonto. ${ }^{1}$ Tho aystom of accounting boloro tho king had boon allowod to grot irrogular, and all tho chiof financial officialo of the crom rere noir inotructed to account in person at atatod timos. At tho aame timo the opportunity was taken of furthor dofining oome of Heron'a dutios. Ee was ordered to pay fixed oume, $\$ 10000$ for "corteymo lilo Eracio extraordinario oxponoio" and $\$ 6000$ towardo buildingo, and ho ras formally givon a field of expondituro which he had anyray beon in the habit of covering. ${ }^{2}$ It matters little whother the detailod ingtructiono concorning accounto and tho like sere evor carriod out; thoy envioagod great contraligetion, and even the chancellor and judges rore expected to report quarterly on the adminietration of justico and the otate of the realm. That is important is this furthor ovidence of a desiro to derelop the chambor into an organisod adminiotrative machino instoad of an informal agency dopending on the

1. B.LS. Tit.B.i, 11.188-90 (L.P. 11i.576, there dated Docomber 1519).

2. Ibid.: "Itom, the kyngio graco hath aloo appoyntod that all Betardio for Ambasadours, and ragia for postio, and other nocessarie expensis astoll for fortificacions of the kyngio frontiors and others the kyngis outo rardo causio shaibo paid by the handie of Sir Iohn Heron...". 
porsonal control of tho king, and capeble of indefinito and undorinod changeo and oxpanoion.

This dovelopment had, thereforo, cortainly bogun by tho time that Tuke took orer the troaourerabip of the chamber, but it had cloarly not gone vory far ao yot. Tho troaguror zas by thon accounting, not to tho king, but to tho gonoral eurroyoro, but ho ras still in the main a hougohold officer ontrusted rith extroordinary dutiog by tho king himoolf. It 10 not until 1534 that wo got tho first oign of Cromell takfing an interest in the organisation of the chamber, in the forn of a ninute addrossed to him by Tuke. It 1o hoaded "Romombrance to Lr Cromel", and doale with tro of Tuto's troubles, his audit and his varranto. 1 It begins as lolloria:

"Sir, the effect of wy huble poticion and deoire of the kinges highnes is thio. Ye knowe that al the kinges officers and aynyotroo, intromedeling ritis any receipteo or paymontes for hlo highneo, haue an ordinary $8 B_{j}$ and meane to be charged and discharged at the lost ons in tho yere, except the treasorer of the kinges chambre who by acto of porliament is opecially and only exompt that be ohal not accoupte in the kinges eschequer no bifore any other person but blforo tho zinges highnes or sucho as hio grace shal appoynt. "Thio accorpto bifore the kingeo highnes hatho botho in

1. B.u. M1t.B.17, 11.117-8 (L.P. Vii.254, thoro dated Fobruary 1534). 
ols Thomes Lovoliog tymo, sir Iohn llorons tymo, and othor, ben rado by bookes of thoir rocolptos and paymonton dajily ontord and wade, and oomtymo rokely oomtymo quartorly or ouory monoth olgned with tho kingos hande withoute any othor accompt or rezonyng; til nowe of late that oir Honry wyat, loving thet ofL1ce, ouod a comyosion to sir Iohn Dauncy to provo and ceot his bokes, whiche was perfourmod and romayn or dobot thorrpon conpeyed, whiche ras a visage or president of ooconde accompto, rokenyng, or declaracion, beoides the said bokes signed. And [it] way be demaunded of mo or wy ouccossourg, ocsupying that offico heroafter, opocio[l]y] soing that acte do not expreseo whithor the said bokes shal[be] takon for a oufficient accoupte bifore tho kinges highnos, or whithor by the aame acte his grace besides those bokes way appointe other to take a furthor accompto of that office.

nfformiche causo my most humble poursuto and dociro is to knore herin the kinges most gracious ploasuro, so that if his highnes be mynded to haue a further declaracion then by tho said bokes bifore his waieste onely, It may otonde with his high pleasure to gouo commysion vnto sucho a person as can do and may attende to the same, to peruso examyn viorso and cagt vp my bokea..."

Tuke rent on to point out thet to leare such a socond account otanding over for many yearo rould load to troublo 
as oridenco may so easily disappear. 1 Having otated his problem, ho subuittod hio proposttion which cloarly ohovod that whet he wantod wao a more exact and regular proceduro deolgnod to protect him againgt the consequonces of any action taken. He rantod hio office to bo organised as a dopartment of tho civil service. "And for the tyme to come, my most humblo pourato is that the oald peroon so evctorisod by compyesion eay monethly peruse examyn and viero my oald bokeo, and therupon set hic name to the same for a wore manyfost declaracion phen I shal present my bokes to be signed by the kinges highne8."

Horevor, this ras not enough. "The thinges bo so groto in recoiptes and paymentes as forro excede ony meano mans charge to supporto or beare, if he shuldo haue no diochargo til the rering or oignature of his bokes", which may be attended with delays, and ho therefore asked that "for thingos ordinary I may haue for paymentos an ordinary warant, And that for thinges extraordinary I may alwais houe special rarantes" or oowe other valid diocharge, "ffor if I shulde make paymentos by comaundment and aftermarde suo my oolf for perticuler

1. "... Then thinges be oute of wewory; strores billes and remombrances broken perishod or gon; the partios dod; or tho tressorer porcase hym oelf, or his clerkes that coude bifore haue answerd to it, ded or con...". He quoted the example of a suit in chancery concorning thinge done by sir John Heron which could only be cleared up becauso, no, Tuke, heppened to possese Heron's boqks, and happened to notice the relovant ontry. 
zarant, I myzo bo vndono in a day, lakelsing any varant whon I oue for it. And thore shuldo bo no day but I ohuldo nolost tho kingos highnos to olgno my raranton; snd I ohuldo ontro Into a combon outo for euery mannos monoy, bring my oolf into Eyotrust whiche of al von shulde not wako and suo myn orm Farantos, nor nouor wan did in that offico or any othor. 1 And bosides that, it myzt bo said my warant wor no warant rhon I waike it and apodo it wy solf; for It myzt bo oald, though I wado a lalso rarant, tho kinger highnoo, truoting mo, aid signe it withouto further examinacion, whiche if hio graco Foldo do I fror as good haue nolther rarant nor boke olgned Fhon al is put to myn oun resporto. And then chuldo ry varranteo nede asmocho comptrolmont as my boiso."

Theso rere all oound enough reasons for hio roquest, and what it all axountanis that tho poculiar position of tho troasurar of the chamber reo disappearing. By act of parliaEont ho rag accountable to tho king only, but a procodent had beon sot by Myat of an additional, wore formal audit; tho king was no longer 80 conscientious as his father had boon in checking the accounto or having thom chockod; and conooquently a careful official like Tuke preforrod to play oafo

1. A dig at Cromroll? At any rato, he mado hio orm rarranto (above, pp.1971.)

2. B.H. Tit.B.iv, f.118: "my bokos whicho I had rody at criotonEas to bo signod, and ras put of by roason that the kingoo highnos appointed thom firat to bo ooon, whicho ia not yot dono." 
eron though that meant cubmitting to a rogular audit by appointod comisoionors, and no irrofular paymonta if thout opocial riarrants. 1 Tho lattor donand aid array rith tho orielnel intontion of making the treanurar of tho chambor a kind of conoy-oponding right hand of the govornment, acting moro ofton on vorbal comands than on viriten ordors, and undoubtedly this sttitude on Tuke's part euppliod an additional soason why Cromell thought it necosoary to gain porsonal control of largo oums of money, rather than orploy the chamber Eachinery. For hiwoolf he could and did oue rarranto aftor

1. Tuko's insistence on spocial rerrants meant a good deal of rork for othora. As he told Lord Lidle: "I pay no thing to anbassadours or their oeruauntes for diottes, postago, or othor thing, but as I have from tyme to tymo opecial rarant ...il that ror not requiaite, neither the kinges grace nor his honourable counaail molde tako the payn at so sodoyn and hasty dopochos as they bo to make and signe warentes to mo, being somtymo xl myle of or more or log." (3.:. Iit.B.i, 1.169V; L.P. $x_{.136)}$. Thore ero other indicationg of hio buroaucratic mind, a torm not intendod to bo dorogatory. Thus he asoured Cromell that tho organisation within bis office vas noro thorough under him than it had over beon: "Your lordohip ohal havo herd rhat ordres I do voo, whicho never troasorers of tho chamber dyd bitmono my clorkes and we. Your lordohip shal Iynde that it is not voray oaoy eithor for wo or then to deceyue the kinges highnes, or for thew to deceyrue we (P.R.0. SP 1/127, 1.117; L.P. x11.II. 1250). Ie found it difficult to got rocoiptes for all hio paycento, for thoso rore a recent innovation and "many gentileon aboute the kingos highnes... bringing we thoir parantes vtterly refuso to subscribo or Govo acquitanco, Afformyng that the possosion of tho marant io wy dischargo" (ibid.). In anothor letter (P.R.0.SP 1\%137, 11.65-6; L.P. Iili.II.499) he oxpleinod why ho wanted payoog of annultios on patents to obtain a dorment writ of liborato, a procoduro rhich ho admittod was novol. But thon, ho sayo, it io an Innoration for patents to bo mado payablo by the treasurer of the chamber who, not being a court of rocord, aftemards 
tho paymonto had boon mado, but Tuko rofusod to do thio and garo roasons which had to bo admittod as valld. Tho dopart=ontalisation of Tuke's offico is boyond doubt, and it io cloar that Tuko's orm attitudo and practico farourod 1t. Tho question which concerno uo io whothor the procoss was affoctod by Cromell's winiotry, whothor Cromoll holpod or hindorod 1 t. can ro discovor him pursuing any dofinito policy rith rogard to tho chambor?

The firot thing that happonod ras that on 25 April 1534 zuto ras fully dischargod of all hio payments in tho past, as be had askod to be in hio minuto to Cromell. 1 Tho patent rabch doclared this pardon ras taken from a oigned bill, fllod as a rarrant for the great soal, which io in Tuke'o orn hand. ${ }^{2}$ It way bo surmisod that after his "romombranco" ho was askod by Crowell to subrit a formal potition in termo oultablo to birself, and that a patent mas riade out accordingly. Thile

had nothing to shor for it: "It ras oufficient to the treasorer of the chambre to knowe the kinges ploasuro by morthe, or in his absonce by a lottre, marant, mossage, or token. And al this ondured but at the kinges wost gracious ploasure, and at the oario pleasure ror rovocablo. Norre they bo for the moot parte during lifo And many by patent... If I ghal pay by vortue of lottres patontes I must havo som thing to ohero for my oolf. The lettres patontes tho partio dotho kope for his suretio, And I may no more pay by tho sight of his lettres patentes than I way by tho onoly oight of his rarant. Therfor, rather then I roldo drivo tho partio to sue tho kinges rarant, I contented only mith a liborato micho bo may havo for $i j \sigma^{\prime} \nabla j d^{\prime}$, or dormant for $\nabla j o^{\prime} \nabla i j d^{\prime}$ if it be during lifo."

1. L.P. Vii. 589(4).

2. P.R.O. C $82 / 683$, no.9. 
Fute himoelf must, theroforo, bo hold rosponolblo for tho rording of the grant, it io cloar that tho king'a minfotor, to thow ho had appoaled, agroed tith it and approvod it ao a zattor of policy.

Tho patent providod both for past paymontr, and for futuro lack of varranto. A lengthy introduction olaboratod Tuko's difficultioo along the linoo of his "romombrance", and it tras then otatod that "re... w0l and by thies prosonteo declaro that tho said bokos of paymontes oignid with out hisnd... shalbo gufficiont warraunt and diocharge for al and singulor somes and paysontes mencionid in the oame to have bone by him paid... and 80 to bo alorid and takyn at al tyroes horoaftor," and the difficulty of paymontes mase without warrant and before tho books Fero signed ("boforo tho ondo of the monotho or of the tyre that ro shall eftsonos aigne tho said bokes") was dealt El th by alloring the ontry of such paymonto in tho books as a relld dicharge if they pore entered bofore the audit of the period to which thoy bolonged. Thore followed a proviso, in caso any wrong dealings or ristakes rore diocovored: "ProFided alraios that if it can bo at any tyico provid that any ontores bo mado in any of the said bokos of paynentes for tho tywe passed...or for the tymo to cono, during tho oeason that tho oaid olr irian Tuke shal oxcorcico tho said offico, and tho saivo sowes not paid accordingly, or that any somes in tho 
same bokos bo vntruly somed or casto pp, Thon tho anid aif Brian Ruko to be angorable thomato an rearon 1s." Thio Eay bo corron form, or a roaul of Tuko's conociontiousnoso, or an insortion domandod by Cromioll tho motave whod to prooorvo a cortain arount of control. Tho torr 8 of tho pardon rore vory ride, and in vier of tho fact that tho body of the documont opeaks trustingly of Tuke's approvod fidolity and his octh of offlce, ro inclino to think that Cromroil wao bobind this pioco of coution.

Go far fuke had actod on his orn initiativo though aith tho approvel of Cromell and the covornment, but in 1535 hio eflairs bocame the oubjuct of direct government action. Tho otatuto of 27 Henry VIII c.62 mado pormanont tho offico of genoral survoyoro of crom lands so eotablishod by tho act of 1523. The position of tho treasurer of tho chanber wao deacribod by otatutes which ostonsibly reforrod to the ganoral ourveyors; ag far as tho lat ras concerned ho ras their opocific treasurer, and hio revenuos rore dolined in tho ochoduloo attachod to acto dealing with thow. Tho making pormanont of thoir office 780 , therefore, anothor atop in tho organisation of tho troasurorahip, a lact rhich is underlined by the rory interosting provioo in the act that purchoood lando and oxchangod lando roro to bo exomptod fro:n ita torms. This put a ctop to any acouigition of erosh sourcos of incomo by tho 
chambor. Purchaood lando rore amignod in tho samo josolon to tho norly ostablishod court of augmontationo, a fact of whlch Tuke complained whon he rocited hin 103000 in 1539.2 Tho court of affmontations and its rovonuos fioro cloooiy Ifnkod with Cromioll's gonoral policy, and Cromioll, as 70 ohall soo, took tho loading part in ita foundation. It id, ihorofore, reasonable to auppore that ho var responalblo for taking thoso posaibilitios of further rovonuos aray from tho chambor.

Tho cage for this supposition can bo atrongthonod. It had apparontly boon intonded to renow the act'for tho gonoral ourvoyora in 1531, at a tino when Cromsoll was not yot tho hoad of tho govornment. Tho draft which survivos differs in only a Lor particulars from tho 1535 otatuto. 3 mo oxictanco of the gonoral surveyors was to be continued until tho ond of tho next parliamont, "And after the laste dayo of tho oaid next parliament duryng his gracyo ploasuro", and the proviso sbout purchased lando ras absont. This draft vas usod in draming up tho onactod otatuto, for tho phraso concorning tho prolongation of tho offico is underlined in the ray rich Cromoll commonly employed whon ho mohod to cancol a pagoago. Thero is a vast doal of ovidence for tho fact that Cromoll

1. 27 Henry VIII c.27, sec.6.

2. LeP. Iiv.II.13.

3. P.R.O. SP $2 / L, 11.112-4$ (I..P. $\nabla .721[9]$ ). 
ras, of all the miniaters of tho crown, the ono most activo in tho proparation of logialation - so much ovidonco, indood, that thoro are sound groundo for sooing his hand in ovory part of 1t; thero is also no doubt that ho ras tho man mout intorootod in financial mattora. It is thoroforo quito likoly that the corroctiono in tho 1531 draft aro by him; at any rato, in 1535 ho ras so fully in control of tho govornmont that no important act of parliamont concerning tho adminiotration could possibly have boen draftod without roforonco to niw. The changes from 1531 rore tho two oignificant pointo Fhich ro havo discovered in the otatuto; the offico was mado pormenent, and it rao doprifod of the poosibility of further rovenuos. Surely ro may not soe Cromoll's hand in those changos and way gay that ho sponsored the moasuro which furthor circumscribed the treasurerohip of tho chambor.

Cromell's policy is nor becowing a littlo clearer. Ho wobed to encourage the existing tondency of the office to becoso a roll-delinod dopartmont. It ras to bo part of a general organiaation of revenue adminiotration, having thorein Ito task and placo assigned. Tho treasurer of tho chambor ras to lose tho froodom of a loosely dofined office and hio excoptional position in the administration by being oubordinated to a proporly eatablishod dopartmont of atato headed by tho general survoyors. This line of dovolopment lod 
otraight to its congurmation in an act paogod aftor Cromsell's Iall which ogtablishod a court of gonoral survoyoro. 1 Tho troasuror of the chambor for the time boing wan, alrayo to bo tho troasurer of tho court. Tho officar concornod almayo doocribed himell therealter by both his titloo.2 Nlthough Crompell did not live to soo the ootting up of this court, it is rebsonable to claim that he must have forogoon and intonded 1t. For one thing, tho policy of nor rovonuo courto ras ono that otarted during his ministry and can isoreover, as we shall 800, bo brought homo to him. For anothor, his troatment of tho genoral surveyors and charbor machinery, as onom by tho sct of 1535 as roll as by hig goneral rolations with Tuke and his revonued, had in effect arrived at the aamo ond without the formality of an ostablishod court. The court of the general surveyors mast, therefore, bo included among Cromell'o reforms of the financial adwiniotration. Tho full oignificanco of this fact cannot bo rorked out until ro havo considerod the other nor rovenuo courto; for tho morient it $\nabla 111$ guffico to say that the court of the general surveyoro, or gowothing very like it, ras Cromell's anowor to the problom of tho undepartmontalisod chamber.

While the revonues of the chamber wero, thorofore, Iixod

1. 33 Honry VIII c.39.

2. B.2r. Storie wS 554, 1.11 , the firot account of tho ner court. 
and limitod, thore roo no intontion of extruding tho troasuror from the paymont of extraordinary governmont oxpendituro. It had Elrayo beon tho practico of tho govornmont to uno any arai28 blo troasury for the purposo of payine oxnonsoo, and crom\#ell'o reforms, Tilile attompting to delino ophoroo of action in the collection of revenue, nover intorfored with this ostab11shed principlo. Thua, for instance, the duchy of Lancastor pald ponsions to tho marquoss of Dorsot and tho king's mastor cook, and tras comandod to pay a restard of 8200 to the opoakor of tho comons, in addition to payments which rould naturally I8Il to ito sharo, as tho 1000 of 1 to offlcoro and annuitioo to tho oteriardo of duchy lando. 1 Similarly the troasurer of tho chamber paid - to give tro widely difforing oxamploo - anpuities to tho earl of Angug $^{2}$ and to Thomas paston of the privy chamber, 3 mile tho exchoquer paid anothor group of annuttios and pensions. 4 The money in all governmont or royal treaouries (tho tormo are, otrictly opeaking, interchangeablo) ras arailable for any aogignwent on it, and cholce rao prosumably gorernment by imodiate confenionco. Then Lord Lislo ras grantod an ennuity his agont 780 in great doubt rhore it would

1. C1. tho surviting accounto for tho yoars 1529-39, B.R.O. DL $28 / 7 / 1-7$.

2. B... Atundel US 97, If.2v, 6v, 34,62,88,102v, 116v, 121 .

3. Ibid. , If.120,133.

4. E.E., P.R.O. E 405/199, whoro tho telloro' paymonto aro givon in dotail.- 
bo paid. 1 To havo doon that ao mastor of tho jo:rolo Crommoll pald man." itoms proviously in tho chargo of the tronguror of tho chamber; rhothor the lattor continuod to pay for aimilar purposed at the same timo cannot be ostablishod for cortain In tho absonce of accounta for tho critical poriod, but lator accounts ghow him again engagod on the gase sort of buolnoso, though boing rivallod by tho troaouror of first imita and tonths, ${ }^{2}$ and thore is thus overy reaoon to oupposo that cromFoll's troasurorohip did not withdram all oxtraordinary govornwont oxpondituro from tho chamber.

Tuke continued to pay man of the Eorornmont'g oxponooo, but he did this nor under a nor and closor control. Cromroll oupervisod him, as he supervisod all departmonts of the admiplotration. As early as April 1533 the ambasaador fith tho exporor appliod to Crowroll whon he thought that Tuke ras boing dilatory in paying his dioto.3 Bonner, in 1539, wroto to tho king for the opoody looue of a marrant as Tuko rould not pay vithout one, and a for days lator Cromell arderod Iako to mako out lettoro of bank to Jonnor's serrant. 4 Com-

1. P.R.0. SP 3/4, 1.94 (L.P. xiil.II.434): "I nold inow wher and in what plasso it rore nost flor your proflytt to be payde. They saythe that the troseror of the ehamber is often Filhout wony, and tho Joyoll horros, augmentaciono, and lyrat erymttes is as 111, anf tho checcker rarsea; and to be paydo at Calay by the treoeror or the rosceyuor io Farst of all." In the ond Lislo rias paid by augmentations (I.P. xiii.II.1069,1112).

2. BOIOT, pp. $I$.

4. L.P. Xiv.I.620,709.

3. L.P. vi.372. 

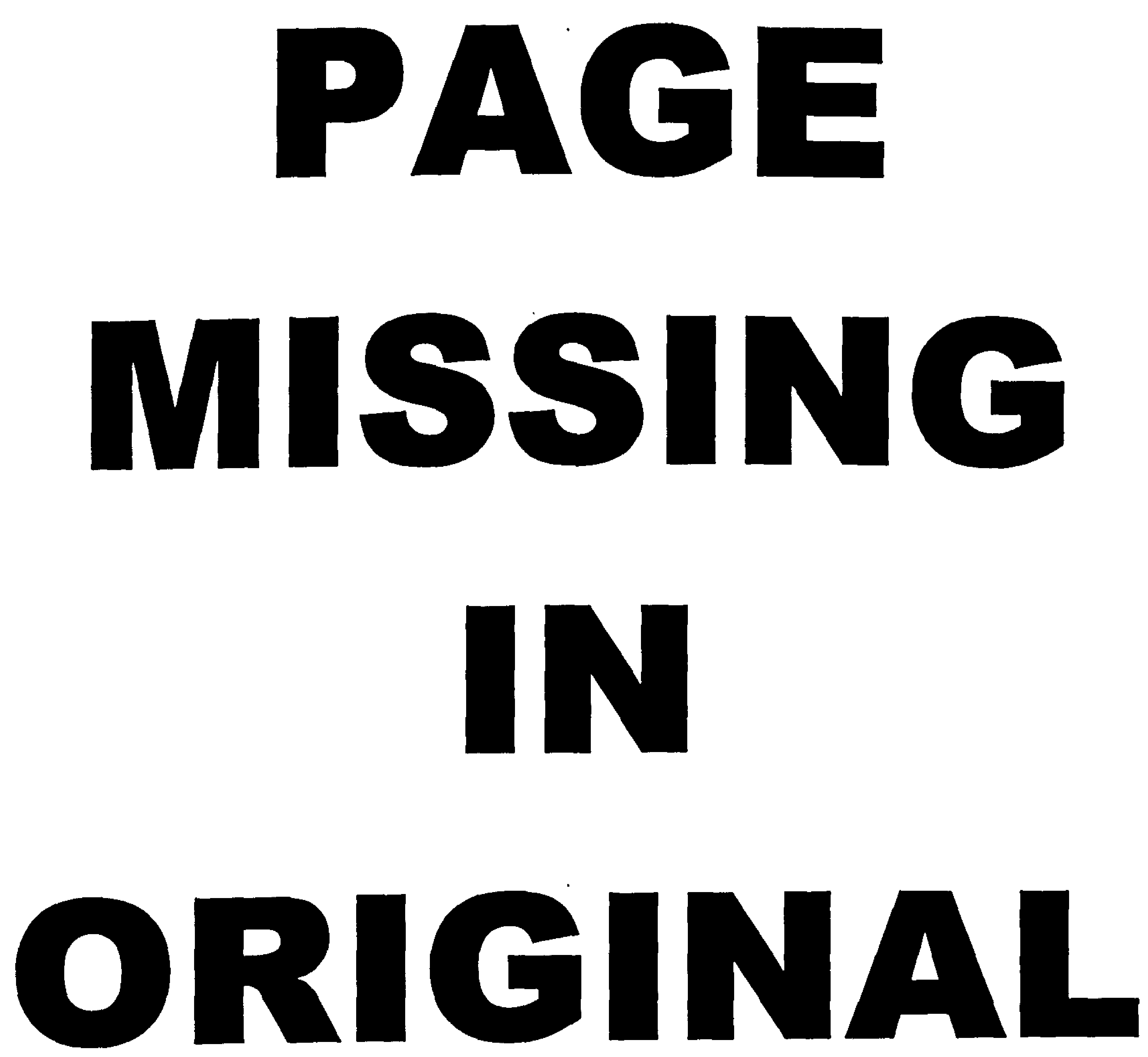
adbinistration soerse to havo mado rocourno to Tuko unnooonsary. Whon, for inotanco, ho was askod for a warrant to luko, to hand oror tho "cosoeg" which troro to pay for tho araining of Lodnog earoh, it appoars that ho diroctod tho siarrant to himoolf. 1 Crompli'd control ovor tho troasurar of tho chasbor was made particularly cloar whon troublo occurred in tho dopartzont. In 1537 Cornoliue Hayoo, tho king'g goldamith, waintaining that ho had boon choatod out of $\$ 100$, entorod a comploint to tho lordo of tho council. 2 Tho accusod clorks of tho treasurer of the chambor dofendod thomsolvos in a dopooition deliverod to the lord privy soal, who had thorofore taken chargo of the matter. 3 Tuko took his clorisa' part and ctated thoir case and his in a lottor to Cromoll; 4 it io not known hor tho mattor onded. Horo again wio havo an ozamplo of the ray in which Crow On another occasion he demandod frow Tuke a dotailod list of tho rages paid through his offico, which tho troasurer for werded with an apology for using only his clorks' books and his orm wemory, he thon boing in the country. 5

Crowrell'g main control was over the oxpondituro of tho treasurer of the chamber, though wo havo soem that ho could

tho kinges "highnoo, And that I shuido certefio you to mororro

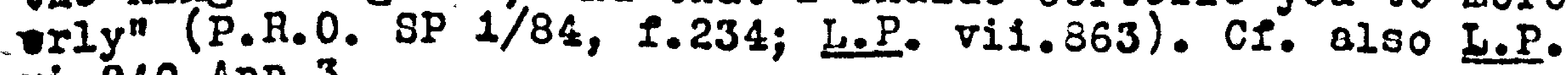
xi.240, App. 3.
1. L.P. $\nabla 1.843,1057$.
5. L.R. XI SP 1/137, 1.176 (L.P. xiIi.II.587). 
aloo withhold or paso part of Tulso's incomo, ruch ao tho much doputod fiftoonth and tonth. ${ }^{1}$ sovoral caooo of Cromoli bolng approachod for warrants diroctod to Tuko havo alroady boon contionod; we may add that ovon Bir iflliam Fitarilliam, treasurer of the housohold and lord admiral, did this shon ho ras about to loavo for Calals on a combioion of invostigation. 2 Doth Cromell's remombrancod and hia corroapondonco contain quito a for referencos to warrante to bo mado out to Tuko, or orders to him for paymont. 3 Those ohor that Cromell uood tho treasurer of tho chambor ao a opending dopartment undor bis orn control. The clearest evidonco for this igprovidod by Tuko's accounts for 1538-41.4 Thore the authority for pajments mado is always quoted, and tho fact omergos that the large majority Nore either authorisod by tho king or by Crom5011. Those stated to be authorised by royal warrant wero almoot all regularly rocurring paymonts, es for instanco for the king's buildingo, the annuity of the oarl of Angur, 5 rages

1. Above, pp.2061.

2. L.P. ix.4, whero he asko for Cromoli's lotters to Tuko. Iho actual rarrant isguod, howover, soems to havo been a roguler royal rarrent: "...haue receyved tho kingoo Letterio and therwith his gracoo rarraunt to Sir Bryan Tuko addrossod, for the Dyottes of mo and part of my Colloges in this our Ioumoy to Calayo.." (P.R.O. SP 1/95, 1.52; L.P. ix.50). 3. E.8., L.P. $\nabla i .995,1056$ (ii), 1194; ix.232,498(3); x.376,1124; Ii.398; xii.I.73; xiii.II.221.

4. B.H. Arundel HS 97.

5. In Lay 1534 Tuko statod that he had so far paid thio annuity by spocial riarrants issued soparatoly for oach paymont. Ho 
and rictualo for tho king's ohipe, housohold dolicito, tho Earrioon at Borrick, tho council in tho marchos of Walos, roEular rages and annuitios in tho hourohold, diots to cortain ambasoadors. Frosuontly tho rarrant for ouch a paymont io doocribod as "dormant", that is to say, it ras mado out for a oorios of rocurring disburoomonts. Othor pajmonto aro costly givon, up to Jum 2539, ao "by tho king'n commandmont, cortifiod by my lord privy soal's lotterg", and aftor that date almost invariably as by Crommoll's lottor only. In a document which generally gives tho improogion of caroful accuracy ouch a cloar-cut chango is likoly to roprosont an actual change of practico. To way concludo that about Juno 1539 cromoll ceasod to omploy a formula which protendod that he rea weroly commicating the king's ordors. Horovor that may nove been, it is certain that all thoso paysuento roro nado on bis authority and initiativo. Analysis shows that thoy woro by Lar tho larger number, and that thoy rore concernod with a varioty of purposos rhich loaves out for thinge that a govornzont wight have to pay for. Loot of them rore wado only once; In contrast to thoso anthoriood by ordinary royal varrant thoy cero not regular or rocurring. It will bo ooen, thorefore, that in tho last yearo of his supremacy Crommoll issuod peraonal

ranted to know what was to be dono about it. It ooomo that Cromiell ordered the iseue of a dorwant warrant (L.F. Vii. 713). 
ordors for paymont to tho tronsurar of the chembor which woro troatod with tho respect usually rorerved for roynl varranto under tho oi rnet and sign lienual.

Once Cromoil, therefore, had fully cotablishod hir appconacy, the treasurer of the chamber became practicnlly as zuch the minister's bmodiate treasurer as ho had boon the king'o in the days beforo Crom:ell took ovor. Thero was, bor:over, a difforence. The relationchip had coasod to bo porronal, and the chariber had boon givon organisod form and a buroaucratic outline. The trocourer of the chasber :ao no longor the wost important financial offecr of the Eovornment but had becose head of one dopartiont amons sovoral, ono cof in a vachine wich vas constently groming lore complicated. Tho internai orjanisation of his oflico had progrossod far tooarde departmentalisation, and wuch of this dovelopment ras duo to the treasurer's orm initiative. Externally, too, thore nore signe of a tijhter or janisation, and hore the moFing epirit had been croiniell's. Cromioll had cut dow and circurscribed tine revonues which rore goine to the chamber, and had put a stop to any furthor expansion on its pert. He bad deprived it of its unicue position in the financial organeation, firet by hinself doing much of the rork hitherto left to tho troasurer of the chamber, and aftermardo by sotting up rival treasurers. On the other hand, ho made no at tompt 
to defino tho fiold of oxponditure loft to tho chambor. The zonoy colloctod thore was still frooly at t.jo disporal of tho zovornmont, at Cromiroli's disposal, and roo uood as Irooly for any purpose that noodod covoring. At the samo timo, cromoll' had establishod a comploto control ovor all monoy going out from the charbor. Tho treasurer of the charbor hod bocome a purely ezecutivo offlcial, edinintering cortain rovonues Thich rore oxponded by the orders of tho king's chiof sinistor. Becauso Cromell's reformo reduced his incomo and cut short his riso to primacy anong tho financial ministries, it is to thom that ro must rofor tho subooquont rapid docline of tho offico. Cromirall rias therofore rooponolblo for tho Lact that the treacurer of tho chamber did not bocomo a porwanent feature of English financial adminiatration. 
IV. Cremeli'g How_Machinory.

An act of 1534 eotablishod the oyotom by which tho flrot sruite and tenths wore to be paid to the king. 1 Ito termo are the mare intereoting because their adminiotrative dotallo vere only partially carried out. They ohow that it was intended to utilize exioting machinery. The value of firot Iruits ras to be assesood by comblsaloners eloo omponerod to take compositions for them and to accept paymente. Of these commioglonere, the chancellor and the master of the rollo wero elroys to be tro, and it is not aurprising to find that the financial officer of the chancery, the clerk of the hanaper, was to keep and account for all the money and obligations derived from compositions made before them. Should the king appoint additional comiselonera, the proceods of their labours rere to go to the treasurer of the chamber. Tentho, to be paid every Chrietmas Irom 1535 onwarde, wore to be esseosed by commiasioners appointed by the chancollor, while their collection was entrueted to the archbishops and bishopo who were to pay the money every year by April lot to the treasurer of the chamber, or - a sigalicant reservation, this - to ouch person as the king wight appoint for the purpose.

It was clearly thought that the ner revenue could be

1. 26 Henry VIII c.3 (stat.Realm, 111.49311.). 
bandled by established dopartmento, and thero ras fundemontally no rosson for doubting this. Tho oumo involvod woro ab yot unknown or, at beat, known vaguely, but siben they camo to bo 8s8es80d and rere found to amount to about $\$ 40000$ a yoar 1 t enot ot1ll havo ooomed that hanapor and chambor could doal with them. $^{1}$ The real difficulty of organiaation, tho problom of aseoseing and collocting, was settled in tho act along lineo that were to prove rorkable and put no additional otrain on the treasurhes used. Howerer, the ochewe was roally rather clumey, with tro different agoncies for tho recolpt and account of the money, and Ilrot Iruits to be difided botroen two ooparate troasuries if additional commisoionors wore appointod. There is no reason to doubt that Crowwell was instrusental in the waking of an act rhich dealt with his orn edditions to tho revenue, the le88 80 as he certainly corrected at le8st one draft of 1 . $^{2}$ Noverthelese, a wost important chango was mado in the projected machinery before it was put into practice, and it will bo seen that this change, too, was Crowell'o rork.

On 7 Lay 1535, belore the firot payment foll due, John

1. Cl. the eatimato given in L.P. $x_{0} 1257(x i 1)$.

2. Li. . Vii.1380(2). One wight conceivably be able to discorer a good deal about his influence frow these corrections, but unfortunately it had proved quite impoosiblo to trace the document at the P.R.O. The reference givon in the "Key" to Li. leads nowhere, and one has to admit that tho draft appearo to have vanished uncatalogued. 
Gostrick was appointed treasurer and gonoral recolver, and

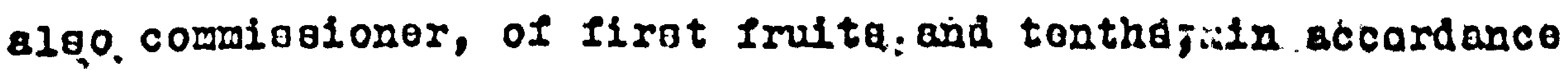
fith the otatute of 26 Henry VIII. 1 Ho 780 actually in offlce by 21 Larch. 2 Adrantage was thus boing taken of the loophole offered by the act when it reserted to the king the right to appoint oowe other person in the placo of the troagurer of the chamber. In addition to his basic duties Gootrlck was also to take charge of othor oources of revenued the L8Enes of lando acquired by the king, particularly thooe of attainted persons (Folsey and Rico ap Oriffitho) and of ouppresed abbeys; the profits of racant oees and monasterlog; and Iines for exporta, for tho escape of prioonero from occlesiestical prisong, and for the restitution of temporalitien. He was 0180 to receive from Crommell certain bonde of the king's debts and to soo to their collection. For these duties he ras to have an ennuity of $100 .^{3}$

It is at once apparent that all his income, except the ner revenue of first Iruits and tenths, was money that Cromwell had himelf beon odministering for tho provious threo

1. LeP. $\nabla i i 1.802(20)$ 2. Ibid. 422.

3. In Larch 1535 John Huseo, Lord Lislo'g agent, reported Gostrick's annuity to be $\$ 300$. His information proved to bo prophotically corroct. In Aggust 1536 Gootwick was granted an odditional E200, tho original oum having boon found insulficiept to meot the expenses of his of fice (L,P. xi.385[12]). It oocmo thoroforo likely that ho rao drawing $\$ 300 \mathrm{p.Q}$. Lor a yoar and a hall bolore ho was authorisod to do 80 by patont. 
joars. This indicates that the aboenco of any accounto of Cromoll'g aftor 1534 reflocts tho lact that ho wao no longor recolving a roll dolinod rovenuo. Qootrick's orn accounto confirm and add to this improooion. 1 Ho claooifloo his income as Iirot imito, tentho, clerical oubaldy, rocolpto irom racant soog, tho biohop of Lincoln's fino for lotting "colloctoro convicted" escapo Irow prison, and Iinos $0800800 \mathrm{~d}$ by Cromell for the making of knighto. Thero 18 also an 1 tom of various sums rocolved from Cromoll and othoro for 1mmediate and opecilied epployment. Very largely, then, GootFick ras to take ovor the revenue which had oorved Cromboll in bio capacity 80 treasurer.

Who was John Gootrick? There geow to have boen tro men of that nawe, brotherg or cousing, for one John Gostrick wrote to Molsey in about 1525, thanking hin for his kinanoso to John costrick, his "germanus".2 It io, horrovor, fairly clear that one man of that name ras being employed by Foloey in various adminiotrativo and firancial sorvicos from about 1597 onfrards. 3 He \#as doscribed as Foloey'o oervant, or his old and trusty oerrant, 4 and in July 1527 ao his controller. 5 He was present at the foundetion of the Iporich college, and with Cromoll and

1. B.L. Lansd.LIS 156, 1 . 146-9.

2: Le. ir.2321. The writer of this lottor doscribed Cromell - asilo orn patron.

3: $\mathrm{I}: \mathrm{P}_{0}: 11.3841 ; \mathrm{p} .1517$.

4: LF: 111.1021,1451,D.1409; iv.2131.

5: Ib1d. $3216,6586(2)$. 
otherg of Folsoy'o corranto recoired the manor of Ravonoton for Folsey's uoe. ${ }^{1}$ Ho was a nativo of Fillington, Bodfordahiro, 18 Lound repeatedly on the Bedfordohire comiogion of tho poeco, and may have aat for that county in tho Roformation parliament. 2 In 1525 ho vrag appointor auditor of cortain rogal property in Yorkahire, and he 10 onco doocribod as king's anditor.3 In 1529 he addroseod Cromsoll ad "hio truoty and loving Iriend". A All this is rory much of ono ploco and io likely to roler to ono wan, on oxporioncod and woll trainod Iinancial official of tho Holooy ochool, bosociated in the pest with Crombell and tranolorrod Irom Folsoy's oorvico to cromergel's in due courae.

In 1534 Cromtrell vas omploying Gostrick in varioue mattors, mostly of a financial nature. Ho handod Filliam Elyo tho lotter requosting hio rosignation as baron of tho oxchoquer: Jith Richard Croswell, he took an inventory of Lord Decre's plate; and he handled mowey undor Cromwoll.5 Even aftor hio appointment as troasurer of first fruito and tenths he remainod in Cromoll's sorvice. In 1535 he was lelt in London to look aftor Cromegll's affairs and had to sook Cromrell'o permiosion to go howe to Hilington; oven in 1538 he

1. Ib1d. 4461,5024 .

2. Ibid. 5132; L.P. $\nabla .909(9), 1694 ; \nabla i 1,56 ;$ Xi1.II.453.

3. L.P. iii.3214(18); $\nabla .166(26)$.

4. L.?. IV, App.233.

5. 店. $\nabla 11.34,663,1011,1353,1364,1496$. 
10 ot1li found thanking Cromiroll for such 11 conco.1 H10 ofIlcial rolations with Cromoll aro lilugtratod by a lottor erom Cromoll in octobor $1535 .^{2}$ This is in offoct a warrant diocharging Gootrick of cortain dutios and ordoring him to tako cortain otops. Ho was authorisod to call boloro him some of tho king's debtors thoso dobto had grown "doopernto", in order to make as farourable a gottloment with thom ao ho could manage. "And this Subacribed with wy hando ohalbo onto you, your holres, exocutouro, \& doputios sufficiont dischargo at all tymos horeaftor." For all tho dotailod control which he oxercised, Cromirell had the good adminiotrator's gift of trusting oubordinate officialo with a cortain froodom of action.

Thuo, rather than comnit the ner rovonue to chambor and banaper, Crommell appointod a oorvant of his orin, an exporionced civil sorvant of Jolooy's training, and also entrustod him With the money which he himself used to recoive 88 mastor of the jeirelo. It is thorofore of the groatost intorest to find that Gostrick's paymonto, undor tho Crommoll régime, included all mannor of things that nore previouoly found in Cromell's orr paymonta. An account of tho yoar 1540 onumoraton, among others, tho follojing itoma: ${ }^{3}$ the justicos and oerjeanto;

1. I.P. 1X. $65,279,301 ; x i 11 . I I .222$.

2: B.I. Tit.B.18, 1f.114-5 (L.P. 1x.647); printed by Morriman, 1.433.

3. P.R.0. SP 1/159, 11.260-4 (L.P. 28.642). 
Cornolius Hayos, the goldomith; Forler at Calalo; Gonoon for ohipe, and for conreying Anne of Clovos; the king's worko; tho king's tomb; rewards to anbassadors and othoro; sadior'o dioto in Scotlond; Fotton's dioto in Cloves; ouppliors of the groat wardrobe. In July 1535 Cromall noted among his rewembrances the lact that he would cause Gostricis to pay cortain diots to ambassadora, rewarda to Irish officiala, and sumo for buildingo at Calais and Dover. ${ }^{1}$ There ourvive tho docketo of Lour warranto paid by Gostrick and waiting to bo olgnod; ${ }^{2}$ thoy also includo a varied number of paymonto similar to thoge alroedy giton. It rould be todious to list the paywonts which costifick nado by Cromrell's ordora; examplos of tho kind indicated can be found throughout the yearo $1535-400^{3}$ Fhen it is remembered that in 1535 Crommell began to be too busy to attend in detail to the businoso of a treasurer, and that ho apparently ceasod to act as one by about April 1536, 4 hia intention with relard to Gostrick's office becomes plain. Gostwick ras to take over the income and expondituro bitherto handled by Crowwoll himself, and was to be Cromoll's personal treasurer. We may suspect that Cromell was responsible for the insertion into the act of 1534 of that reservation which

1. L.P. Vi1i.1077. 2. L.P. xi.381,516.

8. E.g., L,P. Vi1i.1109,1110,1148; $1 \times .65,125,151,252,279,341$, $451,558,836$; x.28,1052; x1.1163,1448; x11.I.1079; II.256, 260,577 ; IIV.II. 53.

4: Abort, pp.175,195. 
aftormards enablod him to socure Gostwick'o appolntment. It 10 probable that he hopod from the firot to haro full control of the ner revenue. His clerkohip of the hanaper rould have given him control of a part, but that ras obriously an unsatfofactory arrangement. Luch the boot oolution wao that adopted in the ond: a soparate treasurer for all I1 rst Iralto and tenths who was immediately under his control.

Considerable light is thrown on this aspect of the office by an examination of 1 te organisation. The trosourer of Iirot Iruita and tentho did not have a proporly organised department at all. He had his clerke and oerranto whom he paid, ${ }^{1}$ but he prealded orer a treagury which was led by agoncios outaide his control. First fruits rere sssessed by commiseloners tho produced, in the Valor Ecclosiagticue, a tax return of lasting value. Compositions rero made before independent officers as occasion arose. These officers wore at first the chancellor and the mester of the rolls, that is, sudoley and Cromsell. Gostrick's accounts show that those tพo alone pere engaged in taking compositiono in the first year of the nerr revenue:(1535).2 The year after, a cortain John Hales ras added to their number, no doubt the same Hales who ras appointed clerk of lirst fruits and tenthe, with porers

1. $I_{1} P \cdot x i .385(12)$.

2. B:H. Lansd.IS 156, 11.146-9. 
to valuate and take compositiono, on 3 Fobruary 1537.1 Except that Chriatopher Haloo took Cromwoll'o placo as mastor of the rolle, these men continued to supply tho treasurer'o incorso in Iirot 1ruits. Not only money but aloo obligationo concorning firet Iruits wero delivorod to Gootrick. In July 1535 he appealed to Cromtroll for oomeone "to ouo the procosos of suche obligacions and opocialties as be comyttod to my charge", the clerk of the leing'o attormey having doparted without letting him know hor things stood, "so that I am not hable to aunswere nether to the Kinges grace nor your Laiotership concernyng thesame". 2 Though, therofore, ho normally relied on the attorney-general in the colloction of hio dobta, he later reported himolf activo in daily calling on debtoro in London for lirst fruits and other debts, adding that he himself

1. I.P. Xil.I.539(5). Ho nould thus seow to have exorcised the office before he ras properly inotallod, but as a matter of lact his appointment had boen under discussion for somo time. In February 1536 an entry in Crommell's memoranda apoke of "an office to be made for the taking of bonda for the first fruitg" (L.P. X.254). In Auguat that year Audeley roluged to geal Haleg's patent because it would tako aray his om authority concorning Iirst Iruits (L.P. Xi.296). His appeal to Cromiell geome to have oucceeded in getting the tormo of the patent changed, for Audeley continued to accopt compogitions for first fruits for another tro years $(1537-8)$. His letter hints that the business ros prolitable to the comisgioners. This John Hales is not identifiod by L.P. With the John Hales who ras baron of the exchequer and one of the king's general surveyors (L.P. Xili.II,p.162n., and index), and Audeley's way of epeaking of him oupports thio. He ras perhaps the, well knom John Hales of Coventry, later clork of the hanaper, but a ner man in 1537.

2. P.R.0. SP 1/94, 11.223-4 (L.P. Vi11.1123). 
had committod somo to rard for non-paymont. 1 Thoro wao nothing in hio patont to pormit ouch high-handed action, and tho chancos aro that ho was ovorstopping tho liwit of his authority rhl to relying on Cromwoll to support him.

The procodure for tentha ras differont. Tholr colloction rant by dioceses and was under tho control of the biohope who poid the money to Gootwick, \&o the account quoted ohowo. However, as the treadurer of firot fruits and tontho did not preoldo over a court of record ho could not koop rollo, isoue process, control the bishops, or call thom to account. Conoequently all the edministrativo businese concerning tentho vas done in the exchequer. In 1535 the net bishop of Saliobury, Hicholes Sharton, ranted to be discharged in the exchoquer for the revonues of the biohopric of tho provious half yoar. 2 In 1536 complainte rere addrossed to Cromell that the booko for the tenth out of the excheruer vore full of mistakes. 3 Accounts for tentho rore rendered into tho exchequer and onrolled on the king's remembrancer's memorands roll. Though the bishops did the rork, the knorledge of rhat needed doing resided, not in their orm diocesan organioation but in the exchequer. In January 1540 a prify seal addressed to the treaourer and barons of the exchequer declared that. In the absence

1. L.P. II1i.II.222.

2. L.P. $\nabla 111.766$.

3. L.P. $x \cdot 423,435$. 
of the bishop of London, Bonner then being on an embaray, the dean and chapter of Bt. Paul'o wore to colloct tho tonth, pay it to Gootrick, and account for it in the exchequer; the iefng'o remembrancer wos to direct "oedules sealed fnder our ooale of our said Eschequire" to the dean and chapter, "conteynyng all ouch Somes of lloney whyth lettres suffyent whythin the same, whereby the aayd Dean and Chapter may bo oufficiently lernid and Inotructed to collect, gather, and recoue the oayd Annuell rent and pencion". 1 Then thinge went wrong Gootwick could not act directly. On 1 Decomber 1539 ho complainod in the exchequer court that the abbot of Bury 8t. Edmunde, responeible for the collection of the tenth in Norrich diocere, had retained the maney and failed to render hio account into the exchequer, "in Contemptum \& decepcionem eiusdem domini Regis ac contro Loges 8u8s; vado predictug..Iohannio Gostwyk petit Auisamentun Curie in premis8is".2 It was not until 29 Norember 1540 that Sir John Baker, chancellor of the newly established court of firot Iruits and tontha, came into tho exchequer and collected the rocords which had till thon been kept by the king'o remembrancer. 3

The question which naturally arises is: why was the business organisation of the trossurer lolt in so rudimenţary a

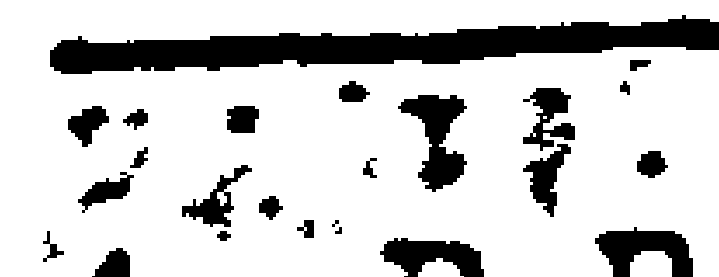
1."P.R.O. E $159 / 318$, m.26.

2. Ibid., Comrunia, Lifchaolmas Torm, Rocorda, m.35. 3. Ibid, 319, Comunia, Lichrolmas Term, Rocord8, t.24. 
otate? Thy did ho carry on for oix yoara under a eystom which Eade him depondont on othor departwonto for orerything excopt tho accurulation and paying out of tho money? Thero 18 an anoper to be found in his accounto. In 1540 ho rondorod what bo hirgelf described as his "Iirgt accompt after the Court vas ootablighed in the oaide yoare $26^{\circ}$, covering the poriod from 1 January 1535 to Ohriotmas 1540.1 For all the joaro boforo tho actual court was oot up Gostrick had ronderod no official accounti. To knor that no such accounto survive; wo may take Gostrick'o rord for it that nono oror oxistod. Yot ho mut have kopt oome form of check on his recoipto and payments, for ho rao ablo to drat up in 1540 a detailod balance for those giz jears. Such unofficial accounto were renderod to CromFell tho several tines roquirod Gootrick to declaro the otate of hio tressury. Thus in ansper to 2 request "to knorso rhat zoney remaynoth Astrell in the lynt, in Robert Lordes handos, \& myne", Gostrick wrote that he knor nothing of the wint for rhich Stephen Vaughan would anower, ${ }^{2}$ but that there ras oome

1. B.M. Lanod.IS 156 , If.146-9. Thio is a copy made in 1609 , which may account for tho mistake mado in the hoading. It nas the office of treasurer, of course, and not the court of first fruits and tenths mhich ras ostablished in tho 26 th of Henry VIII. On the other hand it is posoible that Gootwick himgelf antedated the use or tho term "court", nor that the offico hed actually becomo ono.

2. It ray bo notod in pasaing that the mint, liko all othor inancial departmento, ras kept under close control by Cromrell, though there is no oign of any active or reforming $\therefore$ interest in it. One example of his porrer over it is the 
26470 in cagh in the hando of the yerrol-houso officlalo, of Bowert Lord his servant, and of bimelf. 1 At othor timoo bo Bont proper accounte to Cromoll, as for inotance a otatoment of the recolpt of the tenth for tro yoaro, or a brief declaration of what remained in his clorks' hando. 2 Though no account was rade to the king until 1540, Gostrick ras not uncontrolled, being directly reoponoible to Cromoll who kopt tho considerablo incomo of the troasurer of firgt fruite and tenthe as mach in his orm hand as he had kept the incono of the master of the jerrolo. It ras for this reason that no organisod departront ras sot up for first fruits and tentho. To have done that would here veant giving wore indepondenco to the troasurer than Crowrell was willing to grant. It Fould heve made him more like the treasurer of the charsber whoso comparative indepondence hed originally induced crorstell to indertake a personal treasurership of the king's money. Cromell's intention in sotting up Gostrick's office was to continue this treasurership by delegation, for he pished otill to have large surg at his disposel for the irregular and incidental expenoes of the government.

The eums bnvolrod can be rorked out with some accuracy.

apjointwent of Vaughen, hid Iriend and servant, 28 ito undertreasurer. Gootrick'g wordo make one suspect that Vaughan was put in as Cromwoll's personal agent. 1. P.R.0. SP $1 / 112,11.68-79$ (L, P. Xi.1220). 2. 'L.P. Iii.II.576; xili.II.22 2. 
In Juno 1536 Gootrick dror up an ootimate of hin income, probably as much for Cromroli'g benefit as his orn, in which ho quoted the round Iigures of $\$ 30000$ for "tho Annuall font or Tonth of tho Spititualtio Duo to bo paydo in Aprill next cozyng", and of $\$ 10000$ for "the furot ffructos by ootymacion, Dho and to be due at tho fooot of Thannunclaclon of our Lady". At tho samo timo ho expoctod to collect 112592 Irom dobto and other oources. 1 Tho actuel rocoipto for the yoaro $1535-40$ totalled \&406103, an Evorage of orer 260000 a yoar, but of this \$130711 ras irregular incomo detired from Cromoll and others, and earmarked for opocial purposes; it was monoy for which Gootrick acted as paymaster rathor than treasurer. The totalo givon for Iirat Iruita (\$90069) and tentho (\$156251) shor that the estimate of 1536 erred on the conservative olde Lor the Lormer and hoped for too much from the latter. Togothor the tro yiolded tho expectod arorago of $\$ 40000$. First fruits, in tho nature of things, raried conoidorably; tentho. otarted at $\$ 32018$ and decreaged oteadily to $\$ 18412$, a consequesce of the dissolution of tho sonasteries. 2 Cromell thus continued to be in nearly imodiato control ovor sura comparablo

1. P.R.O. SP 1/104, If.295V-97 (L.P. X.1257).

2. B.L. Lansd.ISS 156, If.146-9. Gostrick'o last account, from Christmas 1544 to tho day of his death on 15 April 1545, shows a quarter's rocoipts of \$29940 (P.R.O. E $336 / 27$ ), but it rould be mrong to multiply by four in order to arrive at a yoar's incore: Lirst fruits and tentho roro both due to be paid in the poriod of the account. 
to those ho had himoolf handiod as mater of tho jorolo, with tho difforence that Gootrick'o income ras rovonue in tho truo oenge while Cromwell had dram on rodorteo of capital.

To round off this question of Gostwick's incomo, it may be added that it derived mainly frow tro oources, for in addition to Iirot Iruito and tentho ho aloo adminiaterod tho clerical oubsidies. The latter had thus boon withdram from the chamber. As re hare oeon, ${ }^{1}$ they rore novor adminiotorod by Crowell, and the $\$ 130711$ which Gootwick recoirod from Cromell and others, by the king's expreso comandwont, can nevo cowo Irom any oource at any timo during the oix yearo. Thero is no justification for identifying that monoy with the 1531 Iino for the presmunire. ${ }^{2}$ The extent to phich Bootwick acted as a privileged paymagter is illuatrated by tho fact that not only plate but even cask was pasged over to him by the court of augmentations. ${ }^{3}$ Therever posolble Cromsoll uged him to cover expenges, and he therefore sam to it that he ras rell oupplied with money.

To heve seen that Gostric was responolble directly to Crowrell, and that he normally paid out money on Cromell's orders. In eddition, Cromrell hiweolf often interfored in watters concerming firot Iruito and tanths. Particularly

1. Above, pp.186I.

2. As does Dr. Dietz (Eng.Gov.Fin,, p.227).

3: P:R:O. GD $15 / 9$. 
whllo ho was master of tho rollo hio corroopondonco includod a good deal on this point. The biohop of Bath oont him a "book of the taxes" of hio dioceso, though Crompoll passod it on to Audeley. ${ }^{1}$ Hie agonte reported actioltios in tho taking of composition for first Irufte. ${ }^{2}$ Some troublo was exporienced over the Iirst Iruite of Laticer and Hiloey after thoir election to tho soos of Horceoter and Rochester, and tho correspondence which ensued ohorf hor directly Cromell controlled these matters. Gostrick wrote that the tro elocts had oont for him, saying that by Cromell's ordero thoy rere to compound with hit for Iirst Iruits; ao he know nothing about it he ranted direct ordera. A Lor days later Crowell's recelver, Polsted, reported that he had accopted Latimer's orn bond bocause the bishop had been unable to find sureties; the buolnegs was complicated by the absence of roliable accounte of the prosita of "their pronotion", and all the detailo rere commuricated to Cromeli. Hilsoy wrote to know what he was oupposed to be doing, since Gostrick hed no instructions to take his sureties, and Polsted did not knor hors much they wore to seount to; this letter illustrates the way in which officers of the crown were bixod up rith Crompell's houdohold officials in the government of the country. Soon after, Polsted acknowledged recoipts of his instractions about Hilsoy, and
1. L_P. ix.383, 450 .
2. L.P. Viii.248; x.363. 
Cromoll himsolf oottlod Latimor's problom in a lottor writton probably to the rocoiver of tho profito of tho vacant 800 of Forceotor. ${ }^{1}$ Evon after ho had cosocd to bo himoolf rosponolble for the taking of compooitiono, Cromsell might otill peroonally order an ex-prior to pay arroara to Gootrick, or to come up and show caugo why he ohould not, 2 and tho lact thet biohop Rowland Loo had sont tho tonth of his diocoso might bo communicatod to him. 3

All those facto indicate a moasure of control which conIfrog out vien of Gootwick as Crompeli's pereonal treasurer in affeiro of stato. On tho other hand, Gootrick himsolf has left it on record that ho occasionally managed to oocapo this control. In a sumxary of his financial pooition, dram up at tho time of Cromell'a fall, he wrote: "lay it pleaso your moost Excellent Maiestio to bo aduertioed That I, your moost humble seruaunt Iohn Gootryk, haue in ay handes Thiche I Treasured from tyme to tyme, onknowne vnto Thorl of Essex, Thicho if I had declared vnto hym Ho wolde haue Causod we to Disburso by comaundement, Without varraunt, as herotolore I haue don I $211^{\prime} .4$ Thio io prool that he usually made paymonto by Cromvell's order only, though he will froquently have obtainod

1. L.P. ix.203,272-3,342,359-60,372,470.

2. L.P. Add.1341. 3. L.P. 28. 562 .

4. B.a. Royal LSS, $\triangle p$ p.89, 1.127. Tho document can bo datod by another (ibid., $f_{.128}$ ) which says that tho 10000 100 in Gootwick'o hand on 8 July (1540). 
a marrant 18tor, ${ }^{1}$ but tho moro important atatomont fo that ho wananged to $\nabla$ ithhold 810000 , or about tro and a half porcont of his incomo in the yoaro 1535-40, from Cromsoll. It 10 on tho whole a difficult thing to bolioro; ono cannot roally o00 what Gostrick hoped to gain by doing this in tho yoars whon Cromell rag oafoly in porror. Only tro oxplanationa for thio money will oatiofy the known conditions of Gootwick's comploto dependence on Cromell, and of Cromell's oupromacy right into 1540. Elther Gootilick had beon doceiving tho lord privy oool, tho woney having been deotinod for hio om pocket, and ho was now trying to antieipate tho diocovery of his poculation rich the inovitable invertigation of Cromell's affaira wight bring about, or alternatively ho was trying to curry favour by attacking the fallen minister, and the money ras simply what ho Fould norrally have had in hand at that particular moment. This gocond interpretation is to some oxtont supported by tho lact that aftor rovoaling tho existinco of tho ourplus gootrick limediately namod oxponseg to bo charged againot it; ho rould in any case have had to koep some money for theso paywente. On the rhole, we incline to tho viow that Gostrick

1. Sometimes ho asked for one (L.P. ix.65,125,451). Cromioll's notos include entries for Gostrick's marrants to bo olgnod (L.P. ix.836; xil.I.1079); and drafto of such warranto draria up in Crosrell'a office ourvivo (L.P. xi.381,516). Lator ho ooems to have had payments authorisod by parrants algned by Cromilel and not the king (L.P. Xiv.I.1269). Ini July 1540 \&15828 hed boon pald by Crossroll's ordor vitiout a frarrant having vo far boon obtainod (B.M. Royal MSS; App.89, I.127). 
rag dofaming Cromiroli'o adminiotration so that ho might play tho just stoward. Tho mothod was tho more oultablo bocauso of tho gonoral chargos of oromooning influonco rado againot Cromell, and bocauso ho ras indood in tho habit of authoriofing paymenta for which warranta would bo producod lator. In that caso Cromoll probably knen alt about tho 110000. Howovor, tho ponoibility that Gostrick ras spoaking tho truth should not bo ignored ontiroly, and wo may boliovo that no ainglo man could be sure of controlling oo many dopartmonto so complotoly and consistontly as Crowoll attenptod to do.

In 1540 the poostion of the trossuror of Ifrat fruito and tenths undorront a radical chango. By tho act of 32 Honry VIII c. $45^{1}$ a nor linancial departmont was oot up, to bo known as tho court of first fruits and tonths. It was to bo a court of record with full control over tho colloction of its rovenuoo. All busineas concerning tonths that had hithorto beon dono in tho oxchequer - tho accounts and cortificatos rendored thoro by tho bishops - mas to be transferred to the now court. Ito nead, by the nawe of chancollor, ras giron porrors to take compositions for firot fruito, elther in peroon or by deputy. The othor officers of the court rore to be a troasurer, attorney, two auditoro, a clerk, a mosoengor, and an ushor, and process in it ras to be "as in the duchy chambor of Lancastor".

1. Strt.Roaln, 1i1.79811. 
The procodure of the duclyy chambor, diotingulohod by olmplicity and offlciency, was usod as a modol for all tho now rovonuo courto sot up in thio poriod. Tho duchy roprosontod a conolderablo adrance on thopothodo employod in tho oxchoquer and common law courto; as a conciliar court it actod by bill and anstor in Engliah, and as a Iinancial dopartmont it omployod a spocieg of declared account. 1 The court of first lruito and tantho was therofore a thoroughly up-to-dato ootabliohEont, tho last rord in adminlotrative officioncy.

Fras this court plannod by Cromirol, or was it oot up as a consequence of his fall? The bill originated in tho house of lordo where it 780 introducod on $15 \mathrm{July} 1540$, fivo wooks aftor Cromell'o arrest and a cloar throo months aftor tho beginning of the session. 2 Fo cannot find the olighteot trace that ouch a project was in Cromrell's mind, whilo the erection of the court of rardo, in the same session, was foreshatowod in his remembrances. 3 Tithout evidence that Cromell had a hand in the measure, and rewembering that his provious uoo of the treasurer of first Iruito would havo bocome imposelble under

1. On the council of the duchy of Lancastor, cl. R. Somorvilio in Trans.R.Hiot.30c., 1941, pp.15911.

2. L.J. I.156b:

3. I.?. IV.438(1). The bill setting up this court was introduced during Cromwell's oupremacy, on 3 June (L,J. i.1418), though oring to its retention by tho commono for oix rooks, at a time rhen the businoss of Cromell's attainder and the Cleveo divorce prosumably took precedence, it was not finally passod until $23 \mathrm{July}$ (ibide, p.160b). 
1t, wo connot connect Cromell with tho ostabliahmont of tho court of Iiret Iruits and tontho. On tho contrary, it $800 \mathrm{mo}$ 11koly that the bill was not draftod until aftor his fall. The remoral of the controlling mind must horo loft tho adciniatration in conoiderable confusion. Suddonly thoro mas a trossurer rithout rooponsibility to any imodiate ouporior and no longer litting into the ocheme of things; the bost oolution of the difficulty was to add hiln to that schomo, that is to say, to wake him tho hoad of a properly organised department. 1 It rould not take long to draft an act rhich arranged for no new businese to bo done, and which for its adminietrativo detail had such modelo as the courto of augmontations and of rards. It could easily bo ready within Lour meeks. Onco introduced, the bill was rushod through both houger in six dajs, boing concluded on 21 July. 2 Novertheless the court does not soem to have otarted rork until Iorember; on the 29 th of that wonth its chancellor, Sir John Baker, replaced as attorney-goneral only threo mooke earlier, 3

1. Should some special aignificance be ascribod to the rords in the preamble of the act which otated that the court should be set up "for the woro suerty and establishmont" of the first Iruits and tonths "and to thintent that the Kingos Usjestio...shelbe the bottor oorved in obtoyning tho promisses, and also from honsfurth be tmely \& justly ansiorid contentid and paido yeroly..."? It is possiblo to ouspect here a reforence to Crowmoli'o poroonal and high-handod control of tho department.

2. L.J. i.159b.

3. L.P. $2 \nabla 1.305(18)$. 
collected the relorant recordo Irom tho exchoquex, 1 whilo dootrick rendorod his ilrot account, which includod ororything olnco his appointmont in 1535, at Chriotmao 1540.2 Thio again ouggosto that tho court rag sot up in a hurry, boing concoivod in an emergoncy and ombodiod in logiolation boloro tho actual adminiotrative changos could bo organiood.

To have hore an oxamplo of sowothing that we ahall moot again: an administrativo loaturo cryotallioing imodiatoly after Cromiell'a fall. After all, Cromwoll'o rulo ras of a highly peroonalicharacter, and ho could mako tho machinery work vell and efficiently by the force and closenese of hio personal oupervioion. The natural result of having no oinglo el1-poreriul minioter woo tho emergonce of a number of dopartwental heads, presiding over organisations which Cronwell had faghioned for them, though hio strong rulo had sometimeo provented thege organisations from achioving their full form. This 788 perticularly 80 in the depertment of tho first Iruito and tontho because Crommoll had moant from tho Iirst to uso it 88 his personel treasury in the business of government. All he required for it was, thereforo, a troasurer imodiatoly and solely responsible to himsoll.

Thile such was his policy for the administration of the

1. P.R.O.E 159/318, Communia, Lichaolmas Term, Rocorda, m.35. 2. B.L. Langd.LS 156, $11.146-9$. 
Llrot groat addition ho mado to the king'o revenue, an entirely different plan had to be follorid when it came to the diosolution of the monasterieo and the annoxation of thoir proporty to the crozn. All that was noedod in the formor case ras a tressurer who mould adminieter money obtained for him by othere. The original assessment could be nede by commisaloners appointod for the occasion, compositions for firot frulto could bo entrasted to existing officiole, the colloction of the tonth could go through the hande of the bishopo. The problems oet by the diseolution of the monasteries, on the other hand, rero ganffold. The houses had to be suppressed, or their surronder had to be accopted; surreys and raluations had to be taken; the monks had to be disposed of; the lands had to be adminlstered; their revenues to be collected, exponded, and accounted 10r; their disposal by grant, lease, or sale had to be controlled; there was the litigation which almayo attacheo itself to property. Such takka could not very rell bo put upon any existing department. Quito apart from their magnitude, there was no one department qualified to deal with such varied duties. That was callod for was a combination of the adminiotrativo abilities a political office like the secrotaryohip, the experienco and porere of the goneral survoyoro in adminiotoring the king's lands, the financial organisation of - lot us say the treasuror of the chamber, and. the equity jurfodiction of 
the chancory. The noarost thing in oxistonce wao tho council of tho duchy of Lancaster, though tho ner dopartment would have c. wach hoavior task.

The problem ras golvod by the act of 27 Honry VIII c.27 which sot up the court of tho augmentatione of tho king's rovenuo, the duchy providing the wodol. Tho court was to haro chargo of all disoolved reifgious houseo and their proporty, oxcopt those that the king rould proserve incorporatod. It Fas also to take ovor the adriniotration of all lando purchesod by the crown, a taek which had hitherto boen in tho hando of tho general curvejore and the treasurer of tho chamber. ${ }^{1}$ Tho king's revonues were boing augwonted not only from wonastic proporty, and all ouch augmentatione woro thorolore logicelly made the sphere of ono department. Tho court was to consiot of a council of chancolior, troagurer, attornoy, and oolicitor, with ten auditors, erenteon particuler rocoirors, a clork, usher, and meosenger. The vory use of the title of chancellor Indicatos the codol, and tho duchy organisation, with ito recolvorgeneral and particular receivera, ite legal officers and auditors, was closely folloriod. In 1539 anothor act as aolened to the court all monastorios diseolvod and ourrendered

1. C1. abovo, p.207. Purchasod lands wore not within tho province of tho Eoneral survoyoro by the torms of tho acto which gavo thom thoir porrers at lar, but they had doalt rith them as of all departments tho ono bost qualifiod to do so. 2. 31 Honry VIII c.13. 
oince the sholoosalo monoure of 1536, oxcopt thoso that had como to the king by attainder, ${ }^{1}$ and conflrzod all oxchangon and purchases of land made in the king'o namo ainco 4 Fobruary 1536, that is olnce the beginning of tho cosolon which pasood tho original act.

Fo can point to but littlo diroct ovidonco that Cromoll tao perooneliy responeible for the setting up of this court. Ho mas reeponsible, beyond a doubt, for carrjing out the attack on the monasteries, and he was at the tiwe (1536) the allpowerful miniater. In the case of firot Iruite and tenthe, ho not only oecured the increment to the royel revonue but aloo porsonelly serr to ito odminiatration, and the parallel is clear. Thile it way be doubtful hor far the policy of those years was his or Henry's, it is quite cortain that the adminiotration and detailed government of the country were in his bande alone. His correopondence testifios to that in ample zanner. If there was a oingle brain bohind the adwinistrative innoration embodied in the court of augmentationo, it zuot have been his. A scheme so carefully rorkod out suggests one individual schemer; the plan requiros a plannor.

Hotever, our case for assuming Crobmoll's influonco in the extter, an influence gonerally accopted though nover 80

1. In 1537 Norfolk wrote to Cromell for confirmation of tho report that the receivero of tho court roro not to meddle with the lande acquired by the rocont attainders (L.P. Iif. II. 53). 
Lar proven or even inveotlected, doon not root oololy on thooo genoral considorationo. It is not our prooant taok to toll tho otory of the court of augmentatione, but it will bo nocoooary to come to gripo nith oomo of ito organioational dotall. A otudy of tho act quickly convinces ono that tho court rao woant to bo an indopondont unit, fully capablo of doaling with all business concorning the dissolvod monastoried. Ono rould thorefore suppose that tho disoolution itoelf ros suporvigod by tho court, and indeod tho commisoionors chargod with it rocoived their ingtructiono from the court and roportod to 1 t. Yet it can be ohorn that Cromsell poraonally had a hand in it. To provo all thio it will be necoosary to digroso.

By a provigo attached to the act ostablishing the court, all housos rithin the county palatine of Lancastor and thoso founded by the dukes of Lanceator were to bo dealt with by the council of the duchy, instoad of the court of augmontationo. (In the fact that tho tro roro conoidered oqually capablo of bandling monastic property ro may seo additional prool that the later was consciously modelled on the oarlier). Tho chencellor of the duchy ras instracted in his dutios in lotters of rarrant of which a draft is extant. Thio mas vitten by a duchy clerk but corrected in a hand which way woll bo that of Richard Richo, chancellor of tho augmentations; porhapo tho court, who rould know boot what nooded doing, ouporvisod tho 
drafting. ${ }^{1}$ Apparontly, horrovor, tho duchy counc1l folt rathor ororrbelmod by the suddon occoso of now bholnoso and found thosgolves laced by a number of probloms. Thoso noro embodiod in a memorandum and oubmitted for an anower to John onloy, the king's attorney in tho court of augmontations. ${ }^{2}$ It oworgos from these questions and answoro that tho combissionors took thoir ordors from the court on all points of dotail, auch ao tho allotment of pensione or the pajmont of monastic dobta. The correct procodure for determining what rolfious houseo rore to be diesolved was this: the king indicated them with bis orm hand "in the bryeff certyfycat", and the chancellor of the court then issued the noconsary instructions to the local commigsioners. Onley told the onquirer from tho duchy that nthoy vee to put A Discreccion to the Comberioners in all suche Causez \& other lyke to be vsed, orderod, \& done, As to them Apon therecucion therof shall seco moste conuenyent for the aroydyng of Claywour of tho paoplo". Ho thought that "it wyll the easyor be allorred when it is done than when it is putt in queotyon"! $!^{3}$ The very lact that the commisolonero rere givon

1. P.R.0. DL 41/12/10. Ibid., no.11 shorro that a docureont dofinitely dram up in the duchy offico ras written by the same clerk.

2. Ibid., nos.11-12. Theso documents are undated but from inEernal evidence are carlier than tho nezt one quoted.

3. Lest it be thought that thio is another examplo of tho ruthlesoneso rith obich the dissolution ras carried out, it aust be said that the rost of the document loaves no doubt that onley was thinking of orrors on the side of mercy. 
a Iroo hand by the court shows who controllod thom. Yot tho commision appointing thom was Cromell's rorls. It was dram up by Thomas Triothooloy, clork of tho olgnet and Cromoli'o chiol clork, and rao corrected by Cromell himooll. 1 Ho may claim that here we have prool pooltivo of Cromroll'o hand in the establishment of the court of augmontationo. As violtorgeneral he had oupervioed the vioitation which procodod tho dissolution, and once the act ras pesood ho san to tho appointwent of the commisioners who rore to put it into practico. Thero ooems no ground for raioing a doubt - a doubt so far nover entertainod - that he 8180 oam to the organiantion of tho department which controlled them, and which was in Iact rooponstble for.carrying out his orn policy.

We cannot leave tho otory of the negotilationo botroen tho auchy and the court unfiniohed; it throrg a good doal of light on contemporary adminiotration in gonoral, though it is only of incidental importance in a discussion of Cromell's adminiotration. On 5 July 1536 a meoting r88 hold at Fostminoter betrieon the chancellor, attorney, receiver-goneral, auditora, and clerk of the duchy on the one olde, and the chancellor, treasurer, and attorney of augwentationo on the other. 2 It

1. P.R.0. E 36/116, 11.50-53 (L.P. x.721[4]). Friothooloy headed it "The lfynute of tho Commsoi on", and that minute here meant aralt io closr Irow tho lact that Crommoll corrected it.

2. P.R.0. DL 5/6, 11.2047-5. 
was agrood that tho duchy ohould doal with all rollglous housoo in tho county palatino, but ohould loavo all othor monaterioo, oron those foundod by tho dukos of Lancestor, to augmontationo. practical conolderationo no doubt docidod hore: tho duchy could not vory vell gond comblosonora all ovor England, into placog where commisionoro of the court woro already activo. Thio rould aloo havo boon unduly rastoful and confuning. Tho duchy ras to havo comploto authority in tho county palatino, whilo tho court rould declere to tho auditoro of tho duchy tho value of all duchy foundations diseolvod, and rould hand thoir records over to thom. A numbor of minor pointe roro aloo agreed on, awong thom oomo originally on the queotionnaire oubmitted to Onloy but then "not moved no Anstrorod As yott". Thio agreoment ras givon official oanotion by boing ombodiod In a sign manual varrant to the chancellor of tho duchy, outlining his revised dutios in the disoolution of tho monasto$21080^{1}$

Crompell's influenco ras also soon in the anpointment of officero to the court. The act eranted no porere of patronage, even 0.0 regarded rocoivere or auditors, to tho chancellor of tho court, and all appointmento roro to bo mado by tho king. It is obvious that royal appointmonto in 1536 rould, to oay tho

1. P.R. O. DL 12/7, no.39. Tho rarrant is datod 11 July 1537 , which may havo boon a miatake for 1536. 
10a0t, bo influoncod by Cromoll'o wiohoo. Cromoll wao thon at tho hoight of his poror; vithout a rival ol thor in tho govornmont of tho country or in influonco with tho klng. If officon rore to bo fllled, Crowoll rao cortainly the man to Iill thom. Tho chancellorship wont to Richard Alcho, tho oolicitor-genoral. 1 Richo ras a laryor of groat ablilty and okill, with considerable ambition and no ocruplog.2 It 18 olgnificant that ho began to rioo in tho royel oorvico about the tiwe when Cromoll 788 oecuring his own supremacy. Richo obtainod a clerkehip at the comon ploas and king's bonch in Larch 1532, and ras made attornoy-general for Fal0o and Chostor in loy that year. 3 In octobor ho was dolng bowo of tho king's legal businese, 4 and a yoar lator ho became oolicitor-gonoral. 5 In April 1535 ho rao appointod ono of tho surveyorg of Iiverion, an offico of fowo importance in tho financial organisation, for which preformont ho gavo Cromell $\$ 40$ and his prayora. 6 Ho orod hie rige to services rondored, particularly to the roll knom part he played in the tragediog of lloro and Fishor whon

2. Ho ras ofrorn of tho offico on 19 April 1536, a baro fortnight after the dissolution of tho perliamont which had eatabliahed tho court (D.li.B., 271.1010$)$.

2. CI. his lifo by A.F.Pollard in D.ll.B., IVI.100911.

3. L,P. $\nabla .909(32), 1065(21)$. The clorkahip 780 a oinecure; tho Fori ras done by one John Cooke who riohod to buy tho offico in April 1534 (L.P. T11.394), but had to be content with a joint appointmont made in Fobruary 1536 (L.P. x.392[32]). 4. L.P. $\nabla .1445,1466,1470$.

5. $\frac{\text { L.P. }}{\text {. }}$ i. $1383(8)$. 6. L.P. Vii1. $490,632(34)$. 
ho actod for Cromoll, or at any rato in tho intoreats of Cromoll's policy, though tho ovidonco doos not pormit any asgortion that ho ras oimply Cromoll's tool. Hio rolationa Fith Crompoll vero those of a frlond and oubordinato. Ho rao too caroful to arrogato a position to himoolf rhich ho did not hold, but could claim to be oomothing moro than a gorrant. 1 By 2536 ho had bocomo a loading logal and adminlotrativo official of tho crom, occupying a fairly important pooltion in tho government prooldod oror by Crompoll. Hio oloration to tho prooidency of tho nor court, an offlce rhich rould call Lor conoiderable adminiatrativo, logal, and financial abilitioo, ras thus the culminating point, for the timo beling, of a otoady edranco under Cromrell'o aegio, and must havo boon due to Cromпel1.

The treasurership of the court ment to Thomas Pope, doocribod in a lottor to Lord Liolo as a sorvant of lord chancollor Audeley. 2 Horover, ho ras introducod to Audoloy by Cromell, 3 and himself doclared that all ho oror had had como Irom Crommell.4 Popo ras a tried civil oorvant vith experience of both logal and Iinancial wattors, who had been koopor

1. Ibid. 456,563. Ono of Richo'g woro unploasant gratto 500 a foignod humility (cf., o.g., L.P. xiil.I.1465, though tho calondaf doos not indicato the full extont of his protonded modosty). Though not perticularly noted for his pioty, ho almost almayo hoadod his lettors with tho vord "Ihus".

2. I.P. $x .573$

4. Le. Xiil.II.106(ii).

3. L.P. 28.351 . 
of the change and monoy in tho Torer of London, and ono of tho clerks of the otar chamber alnco lato in 1534.1 Ho ronignod the troasurorahtp before 17 Uarch 1540,2 bolng aucooodod by Edrard North tho had boon clork of parllamont unt1l 1539 whon bo wade may for ono of Cromoll's own socrotarles, Thomas soulemont. This auggeste that llorth's appointmont, too, may bevo boen due to Cromell who way havo prominod him promotion if he resignod an offlce to which Cromtroll wiohod to appoint a poroonel sorvant.

Cromeli's influenco is as notlcosblo in tho appolntment of the other tro chief offlcero of the court, the attornoy and the solicitor. The former, John Onley, was reporting to Cromell, thon at Calaio, on logal affalrs in London, and oooms to bave been ablo to call togethor tho king'n logal coungel. 3 A report of a riot in which nombers of the influential fitzwilliam family wore attacked ras addreosed to $\mathrm{him},{ }^{4}$ and ho had an act pasood in parliamont in hio Lavour. 5 Desplte his obocurity he appeare therefore to have been a lamyer ofisome standing whom the lord chancollor could describo as his Iriend, 6 and he cortainly had boon in intinato contact with Cromoll early on in the Iatter's careor. Then he died, about Decomber

1. L.P. Vii.1498(12),1601(33).

2. $\mathrm{E}$. $\mathrm{P} .2 \nabla .351$.

3. L.P. $\nabla .1455$. Thio was in 1532; ho cannot bo tracod any Iurthor back.

4. L, $P$. Vii. 1120 .

6. Le. xii.II.1160. 5. L.P. $2.1087(11)$. 
1537, and the offico - oatonsibly in the king's glft - 1011 vacent, favour and preformont woro oought of Crorstoll ao a Eattor of courao, confincing prool of our otatowont thot at this time royal patronago woant Cromroll'o patronago. S1r Francis Bryan roquostod tho offico for a Wr. Lolinox, 1 but Audoloy ouggestod that tho oolicitor of tho court bo promotod and that his offlce bo filled.John Luces, a latryor of the Towplo. 2 The oolicitor, Robort Southwoll, obtainod hio pronotion. He ras a wowber of a Horfolk farily, connocted rith tho family of tho duke of Norfolk, but oron more clonoly mith that of Cromiroll.3 Hio brother Richard acted ao tutoi to Crowell's oon Grogory. Robort mao in Crommell'g oorvico in 1535,4 and ras close onough to him a yoar later to bo givon oomo notes of hia brothor's for comwunication to cromoli. 5 Ejo successor in tho solicitorahip, howoror, ras not Audoloy's protogé Lucas, but a cortain Falter Henloy or Hondlo who wao a comiosioner for the supprosolon of the monastoriog in $80-$ voral countios 6 but is othormiso obscuro. Shortly after teking up hio nor office ho wrote to cromsoll, agking for inotructions.7 Altogother, tho eppointwonto in tho court of augmentationo confirm that it ras Cromoll who organioed the
1. Ibid. 1177.
2. Ib1d. 1160.
3. For Robert Bouthroll, cI. D.N.B., soli1.701b.
4. L.P. Viili.539.
6. Ibid. $721(6)$.
5. L.P. $x .507$.
7. L.P. IIIi.I.195. 
nor dopertment.

Thus tho court ras Crowroll'o rork, though ho w11l havo had advice and holp Iroin othora. Tho rolatioly haphazard wothodo omployod for tho adminiatration of firat fruits and tenths roro out of tho nuoation whon groat landod proporty wao concornod, with all tho burdona and dioputoo attondant upon it, Fith the troublos inhorent in quostions of titlog and tho dioposal of lando by 10800, salo, or grant. ${ }^{1}$ Tho monks had dopartod, but bohind thom thoy had loft dutioo and obligationo Fhich tho goternment ras detorminod to moot. Thero roro leases to be carriod over, and dobto to bo paid.2 The dissolution itgolf infolvod the sending out, instructing, and controlling of commissionors, tho collocting of load, gold, and precious otones, the survoying and regiotering of landry and

1. "The same bourte shall haue auctoritio and pov[er to] horo \& dotormyno all Latioro betron partios onymiso touching ony Lordshipp, Landes, tenomentos, \&c, nor boyng or that hereaftre shaibo rithin tho Survoie and Gouernance of thooamo." (P.R.O. E 163/11/49:. This documont is a roll containing a number of projected roforms in tho court of augmontationo, not in that of the general survoyoro as is orroneously statod on the modern covering membrane. Loot of the points montioned rore, horrever, embodied in the part of the act of 33 Honry VIII c.39 which reforrod to augmontations. Tho roformo may have boon planned by Crorsell, but they woro carried into offoct aftor hio fall; in the aboonco of any ovidongo of his influenco tho point cannot bo usofulity discusoed).

2. "Tho oaid Commssioners shall take tho notos of all 100000 mado, and the same to bo examynod, So that it may bo knotron Hore long tho seld 100800 shall contynuo or indur... Itom, the said Comysoionero...to pay all true dottos of euory house, boing vader the value of $x x$ li'." (P.K.0. DL 5/6, I.2048). 
a hundrod and one othor taoko. Tho monko had to bo ponolonod off or had to bo sont to colloct thoir "capacitiog", tholr 11concos to bocome socular clorgymon, though tho actual isauing of thoos inas dono in the chancory. 1 The quootionnalro dram ap by the duchy of Lancastor providea oomo oxasploo of tho dificultios oncountorod by tho comingionora. 2 Tho quostiono ralsed includod these: That is to be done rith monks who righ to continued in rolfgion whon thore aro no houses of thois own order left noar? Hor wuch of thoir porsonal bolongings, ao Lor ingtanco.bodding, aro monks allorod to tako with thom? Aro riate and tiles to bo romorod from roolo, or only load? aro bolls to be ronovod from stoeples, and who will take chargo of tho lead and bolis? "Tho Shalbe Admyttod to sorue tho Caros of such churchoo As bolongo to the oold Houses Thorof is no prioct inductod but at "fyll?" That iiving̈ or nonsion is to be given to the late "governors", and are they to bo inductod to bonofices boforo tho king has docidod furthor? Fhat Is to be done rith monks and lay almonors rho aro too roak or old to bo movedp

Ilo singlo man was littod to doal with yo many divero problems. Cromell's solution of tho difficulty nas tho ootablishront of a conciliar court, a dopartwont organicod on the

1. P.R. 0. 36/116, If.50-3.

2. P.R.0. DL $41 / 12 / 11$. 
Inoo of both on adminirtrative council and a court of law. Tho ago krow littlo diforenco botreen tho tro, an tho hiotory of otar chamber and privy council ohoro plainly onough. It Fos an advancod form of administration, and ito application to the now royal rovonuos wur: bo ascribod to cromili. The court of ausmontations wao tho first of the nor coller it carkod a definito departure from the policy oxomplifiod by the rise of the general survoyors and troaouror of the charbor, and ochoed in Cromell's mastorahip of the jerelo and Gootwick'n troasarership of firot Iruits and tontho. Thio oarifor policy usod spocial, undepartmentalioed officials, undor the imodiate control of king or minister. Tho nor court representod a considerable advanco towarde a buroaucratic orgarication, able to continue its rork whatoror changeo wight occur in the governmont.

Yot while the court ras capablo of atending on 1 to omn Loet, and was in lact designod to do so, nothing was furthor Irom Cromeli's wind than to lot it olip aray Irom hio porsonal control. Ho kept in touch with the comiloolonors who wero supproseing houso, oron though thoy rocoived thoir inotmotions Irom Richo. One of thom reported on the survoyo ho had made, gont a statemont about thom to crommoll, and aokod whother a lettor Irom Richo and Onley, ordoring his roturn to Catooby in Iorthamptonshiro, ras onfficiont rarrant for his to 
do oo without confirmation from Cromoll.1 Evon tho duko of Sorfolk, active in tho north aftor the pilerimago of graco, rocolvod instructions on tho supprosolion from tho court of augzentations, but he told Cromell all about his activitios.2 Cromell'g influonce ovor tho court ras prooumod by a country Eentlemen riho askod him to havo Richo ordor tho comblablonoro to opare "hio" priory, of which ho had boon solsod for noarly tro yeare. 3 Although tho routine rork of tho court was norwally dono by tho chancollor and council, 4 cromoll intorforod on Irequent occasions. Ho doos not soow to have ordorod Popo to make payments rithout warrant, but ho backed rarrants ith porsonal lettore rhich opoodod paymonta up quito noticoably. Thas Cromell inforwed Pope that ho vas to pay Lord Liolo's onnulty of 2200, whilo Popo on othor occasiono acknorledged tho rocoipt of such lotters and roportod that he had paid a

1. L.P. x.1215. The oamo man, George Gyffard, roportod oimilar business in another letter in mich ho also opoko of tho king's angor at his daring to roport lavourably on somo roligious housos (ibid. 1166). Ho recomronds anothor houso to Cromoll, trusting in hio "indifferenco" (falrnoos). This lotter drars a nico distinction betreon the attitudes of king and miniotor to the monastories.

2. L.P. xii.I.478.

3. L.P. 2.1038 .

4. EOod deal can bo loarnod about tho rorking of the council from a largo numbor of documento - roceipte, ordoro to pay, minutes, otc. - Thich onco undoubtedly belongod to Popo, after that to Richo, and rore tranomitted through him to the Lanchester Papers, nor deposited at tho P.R.0. (GD 15/1-114). Ono interesting point is that olnost o.ll business $800 m s$ to haro boen dono in Iull oosion, many of tho documonto boaring tho signatures of all the officors except the treasuror to rhor they nero oddresood. 
ous due on the king's rarrant.'

One roason why tho trocouror of tho court carso in closor contact with Cromoll's moro poroonal financlal organioation roo that ho handod epocio, jowalo, and rolico oror to Gootrick.2 In this connoction Cromoll wrote hit a lottor which provos hio own activitios in tho mattor:" "Fforamucho 0.0 ny frondo Iohn efreman hath by the Kingos hieghnoo comaundowent, at my modiacion, dolyuorod" cortain plato to Gortrick - Iolloriod by a sharpish robuke bocauco Popo had rofucod to lot Frooman havo a ritton acquittance. The lord privy ooal kopt an oyo oron on ouch small detaila of tho financial adminiatration. "I doo oumbat marvail that you gyvo hir: not a diachargo, And Thoroforo thought we to Recuyre you that ye shal, ao it apportoynoth, doliuar vato the oald efroman an acquitaunco theroof." Cromwoll 78 not abovo carrying rolics hingolf from tho court of eugwentations to the king. Thore is a note, in Richo's hand, on the face of a varrant which orderod Pope to hand over a pleco of the Holy Croso Irom Stratford to Thomas Henneago: 4 "Bo it rewembored that tho relik abovo romomberid, named to bo a pece of the holy crosse, wao delyuerod to the kyngos magosty at Hamptun Court, tho ixth day of Iuno Anno xxix Regni Sui, by the handos of my lord Privay 80ale, as my lord Chancollour \&

1. L.P. XIV.II.282; xi1.II.274.

2. E.8., P.R.O. DD 15/28-9.

3. Ibid. 100. This lottor nas ovorlooked by Lorriman, though it is wentionod in H.lS.C., 8th Ronort, App.II, p.16.

4. P.R.0., GD 15/28. 
Laster Chancelour of tho Augrontacion can rytnoz." A moro laportant oxamplo of Crom:oll's interforonco in tho affairs of the court ras tho comisision which he had mado out to hirsolf and Richo, authorising thor: to sell ouch of tho king's lands as had come to him by act of parliament or rurroncor, to tho clear yearly value of $\$ 6000.1$ crominell $7 a 0$ caroful to noe to it that the control of tho king' landn, and thorcfore tho king's revenues, did not escapo from his hands.

There is, moreover, evidenco that the syotom did not rosk ao perfectly as its clear-cut apperrance might ouggest. $\Delta 1-$ though the court of augmontetions had beon not up in order to doal with the suppressed and surrendored monastorioo, it was not fully master in ito orin hourc. Aftor tho smellor monasterieo had been disposod of under the act of 1536, the roluntary or forced surrender of the romaining hounos beckwe cause of dispute betroon various offlcials. Tho commissioners sent out by the king's vicogerent eppoar to have beon indopondent of tho court of augmontations and rosponsiblo to Cromoll alono, so that agento of his interfered in the court's sphoro of action. A letter Irom Riche to Crommoll, viritton on $26 \mathrm{July}$

1. L.P. xir.II.780(36). This commisalon ras dated 14 Docombor 1539, but oven in the year onding at Lichaolmad 1539 tho tro won had boen solling monastic lands by virtuo of a opecial commission, to the valuo of 80222, as Popo's accounts shors (P.R.0. $\$ 323 / 1$, part II, m.13d). In Uarch 1540 Crom ell also obtained a commiosion, togother rith Bir John Daunce and Richard Pollard tho gonoral survoyors, to 8011 lands under their charge. (L.P. X..436[38]). 
1538, ohowe the difficutilos oncountorod by a dopartwont rinich bed to doal with an all-pororful minietor proparod to do oron routino work. 1 Tho point at 1 souo nas tho ourrondor of $8 t$. Augustino's, Canterbury, "tho survoy of tho posoosolong Fhorof," Eroto Richo, "apporteynith to myn offico is to oucho as bon oficoroo in the Court of Augmentaciono". But ho did not oish to "noclect or bo remyoo in doyng my dorty", and thoroloro asked Crommoll to lot him know fhothor ho "ohall causo any of tho officorea of tho Court of Augmontaciono to mako survoy or not; or elo, whothor sucho as your iordship do apoynt for the disolucion of the borsoz shall doo tho came". Somotinos, apparently, tro soparate survoya had boon wado, and - what vas Forse - "your lordabip knowith right woll ther bon oondry Surroys Certifiod by sucho that hath dis80luid horsor, apon tho richo yt yo not posaible to procede to grauntyng of any 10030 Jnto oucho tywo as a nor survoy wore wadon. Ho romindod CromFoll that "your lordohip diueroo tymoz hath oaid to wo that your officeres abold nat wedyll with the survey of tho possossions of any horsoz, but only fith tho surrender, disgolucion, \& the goodes". This thoorotical division of lobour lolt tho officors of the court rith tho duty only of survoying the lando, that is, of ostabliabing the facto taken into considoration when the fato of tho propetty ras docided.

1. P.R.O. SP 1/134, If.249-50 (L.P. xi1i.I.1465). 
Fo wot, thoreforo, apparantly diotinguloh botroon throo nota of officialn. Firetly, thoro rero tho comminalonero eppointed under tho act of 1536 rhoso comminaion had boon draftod by Cromroll. 1 Thoir dutios included the nurvoy of noosonglono as well as the tooks reoulting Irom tho disoolution. Although Cromill had nporvisod thoir appointmont, tho attorney of tho court of augmontations instructod thom in tho dotallo of thoir rork and ito chancellor proricribod to thom what monasteries nere to bo disoolvod.2 Thooo elrot commisoloners vere, thoreloro, rosponaiblo to, and controllod by, both Riche and Cromill. Howevor, their taok ondod rith tho disoolution of the sbalior monastoriog. The adminiatration of the neily acquired proporty foll to tho local recolvers of tho court of augmentations, $n$ different not of mon. Thon tho attack on the eronter monasteries began tho court had no poror to dissolvo them, and the work was thorofore ontrusted to a third group of officialo, commisaionors spocially sent dorm by crommoll in hio capacity as vicar-genoral (or posolbly ao vicogerent) to take tho surrendor. Eut those lands, too, onco thoy had boen acquirod, more adminidtored by tho court, ovon boforo tho act of 1539 regularised tho position. Consoguontly deflicultios and even friction arose betioon the regular local

1. P.R.0.E 36/116, I1.50-3.

2. P.R.0. DI $41 / 12 / 12$, which gives Onloy's replios to tho onquiries Irom tho duchy. CI. 8100 L.P. $x .1166,1215$. 
officialo of tho court and Cromoll's opocial commosionorn. an unouccosoful attompt ras mado to allot thom noparato dut100, but cromiell's agents continued to cut across tho ontabliohod dopartiontal linos of tho court of augmontations, renderine thoir unreliable ourvoyn and groatly annoying Richo, though ho couchod his lettor in almoct abjoctly humblo torma. OromFoll had ostablishod tho court, and he oxorcinod a conoral, and soinotimes a particular, control ovor it. iovortholoro, he did not consider that the oxictonce of a sopornto dopartment doaling rith monastic lands complotoly proventod his porsonal activitios in that direction, ovon though at timos ho made tho besk of tho court very difficult.

1. Those throe groups wust not bo confused with the comisoiono which carriod out tho groat visitation of 1535 and compilcd tho Valor. Tho samo mon, of courso, wight bo on moro than ono cormisgion. 


\section{Tho Financial Adminintration aftor Cromoli'o Roformo.}

The court of sugmontations rag the firgt of the nor rovonue courta, and it ras followod by throo othorn during tho reat of lionry's reign. iono of theso van net up undor CromFo11, though he had planned tho court of riardo. Among his; noter is the ontry "the entablishing of a law for tho Court of "iarde", moavino no doubt that ho ries bohind that roform. 1 This court provine: proot how vory now the thole idoa of ruch orgenised departmonts ras. Thoro survives a womornntum "for a good Ordre to be takyn for the kine our nouerain lordea wardes", which outlines cortain necoosary roforms to provont further decline in the rovenuos of that office. The calendar acsigns the document to the yoar 1540, but thoro is no ovidence to oupport that dato. Tho paner addrosses itsolf to "your grace", and as the king is mentionod reveral timos in tho third person, the torm suggests that irolsey ras meant. 3 inatover its dete, its contents are vory intorosting to uo. It describes the syotom in existonce under Henry VII, thon thore hod been a mastor, genoral rocoivor, auditor, and a particular recoiver in every shire, for t:ards' lando. Cortain writton

1. L.P. $2 \nabla \cdot 438(1)$

2. P.A.0. SP 1/159, I1.47-8 (L.P. 27.503).

3. I am asoured by lír. J.Huratifold of Queen i.jary Collego, London, who is at prooont invostigatine the history of the court of rards, that ito description of tho otato of tho offlco Iito much bottor tho lato $1520^{\prime} \mathrm{s}$ than tho $1530^{\prime} \mathrm{s}$ whon Paulot had introducod some ordor and officiency. 
rocordo hod boon kopt, and all rardohlpo had boon otrlctly controllod. Sinco that timo, horovor, tho nyotom had boon allowod to fall into disuso, with gront consoguont loge to tho king. Tho writor thoroforo rocommondod that tho officoro of Henry VII'g timo bo appointod again, and in eddition to thom "gowo bblo person of the Chauncory or of tho Egchoquor" to koop tho rocorde of rardohipg in somo placo oagliy acoosalblo to tho officers concornod. He also proposod a genoral ovorhauling of the sales and $108 \pi 00$ of wardohlps and vards' londo, 00 as to preservo tho king's just rights. This plon did not Involvo any departuro Irom ootabliohod practico, and in 1 to provision of a opocial clork in tho chancory or oxchoquer to look aftor wards' rocords it quito disrogardod the pohsibility of sotting up a dopartmont for rards which should bo a oelfcontsined court of rocord. Howoror, that was the roform rich Crownoll's note foreshadomed, and which parliament carriod out by the act of 32 Honry VIII c.46. Doopito tho oxiatonco of a difforont plan, ono that had boon tried and found good by that groat roformer of adwinistration, Honry VII, Cromell puohod through his farourito plan af a court modoliod on tho duchy of Lancagtor. If, as ocoms likoly, tho documont ras drarm up boforo Cromoll'o riso to powor, it rould furthor oonfirs that the idoa of revenuo courto $7 a 0$ his orn. The court of Iirst Iruits and tontho, and the court of 
tho gonoral ourvoyoro woro ootabliohod aftor Cromioll'a fall. Bomovor, thoy roro basod on Cromoll'o "nom modol": dopartconts organisod in such a mannor the.t thoy could do thoir zork without dopondonco on any outsido agoncy. Thoso courto IIth thoir orn oo8lo, chancolloro, 1 troasuroro, auditoro, and clorks, and with thoir local organioations of rocolvors of rorenue, rere sot up for the bottor administration of the royal inancos. The departmental hoado did thoir rospoctivo rork Fith tho help of a fully otanfod offlco and assioted by a council which had the porrors of a conclilar court of lart. The model was the duchy of Lancastor, ${ }^{2}$ but the 1 doa of using tho modol, and of extending it to tho contral public administration, was Cromwell'o. To cannot toll whother ho himoolf planned tho furthor application of tho wodol which his succesoors carried out, but ro havo shown that if ho had dono it Lor firot iruits and tentho ho rould have had to broak with the other olde of his policy, his dooiro alfrayo to havo somo treasury under hio immodiate control to provido tho fundo necossary for tho carrying out of his pollcy. It was groatly to his disadrantago that ho 780 a ministor and not tho king. Unlike Henry VII ho could not exorciso unlimited control ovor an organisation dovoloped from tho royal hougohold. Honco

1. The first officers of the court of gonoral survoyors rore, howover, called gonoral surveyoro.

2. Thio is cloarly atatod for all tho courto oxcopt tho ourveyors ( 27 Honry VIII c.27 soc.11; 32 Honry VIII c.45 soc.5, c. 46 80c.13). 
tho declino of tho troasurer of tho chambor an tho contral opondine departmont, and of the conoral rurvoyorn no tho informal court of nudit for ovorything not bolonging diroctly to the exchecucr or the duchy of Lancastor. Croitroll solvod tho elrot pert of his problom by flrot mkelng himols a tronsuror in control of largo sums, doribod largoly from rosorvoo and opent on extraordinary and irrogular expenditure. ithon bo could no longor carry out such dotailod dutioo bo found a convonient substituto in the troasurer of firot fmalte.

There are, thoroforo, tro main lineo munning through crowoll'g policy for the Iinancial administration. On tho one hand, he righed to be in personal control of sufflciont funds to maxo himself indopendent of any other treasurer. on the other, he vished to organise the rovonue under departmontal ministries. Tho lattor, ro may oay, was his idoal, but circumstan:08 provontod hit from carrying it out in ovory sphere. Then he could act rithout rejord to his own nood for oponding money he doroloped a syotom which ras tho oppooito to that employed by Honry VII. In tho place of rathor rague houschold offices responsible by word of wouth to tho king, he and his succosoors put orgenisations, courts of record - in other rordo, departionts of stato. Tho consoquent Ealtiplication of officos roquirod a suporior authority rhich rould control and co-ordinato thow, and as long as ho lirod 
this authority rosided in Cromoll himelf. Lator it wao found nocosoary to subotitute sorathing olso for tho authority of the ono minister vocaupo no-ono with tho requiaito ability, knomlodgo, and industry camo to tako cromoll'a placo, and also perhaps bocauso tho procose of bureaucratloation which he had begun was to bo carried furthor. This aubstitute ras provided by tho rolorwod oxchoquor.

As re started this chapter with a document shoring the inancial organisation at the timo of Cromoli'a coming to porer, re cannot do better than close it with one rhich ohoro the changes he had made. It is a paper in the hand of Ralph sadier, still oflerk of Cromoll's though also a clerk of tho king's, witten somotimo in tho first half of 1537, and hoadod "Cortain articlos touching the fortification of the kingos Tornes of Berrike, Carlill, and other his graoos Caotles and flortressos in the North parties". 1 The first paragrapho doal with theso points; but there follow notes on the collection of customs and subsidies which rere bringing in 108 than expected, on the payment of a grant tro yoars in arroars, and on a survey of subsidiog, colloctors of which "hauo manifeotly decesued the King". That interests us are the last

1. P.R.0. SP $1 / 119$, 1f.105-8 (L.P. Xil.I.1091). L.P. stato that the paper contained Mbusiness to bo laid boloro tho council". Thoro is no oridenco Lor ouch a statoment in tho documont which wo rathor think vas a somorhat formal notos of Deroranda for Cromeli'o attention. 
I100 poracraphe which not out ordors to bo loouod to tho court of augmentations, tho troanuror of firot fruita and tonthn, tho troasurer of the chambor and gonores -urvoyorn, tho otficors of the exchoquor, and tho chancollor of tho duchy of Lancastor. Each of thom $: \because 8.0$ to rake e. full roport of tho otato of affaire concorning lando and tho liko undor hio control, of his incomo and expondituro, of tho "offlcos, ffooo, annuitios, or chargos ordinerio" and tho "extroordinario chargoo" payablo by him, and "rhat the hole romaynour to tho Kinges vae rill yorely amounte vnton. Thig last point wan tho rosl purpose of tho survey, as a note at the bottom of tho paper shors: "Ey weanos rhorof the Kingoo lighnoo mayo kno:e his ostate, And by moanoo therol mayo establieho all bio affairoo; And thorby bo putt ar ordor hore a cortain tresure jorely maye bo laid op for all noconoitiog." 1

Hore, thon, is a list of Iinancial doportmento which hao added to the threo old ones of oxchoquer, gonoral surveyors, and duchy of Lancaster, the now oneo of tho firat fruits and Eugmentations. Evory one of theoo departmonts is deacribod as an office, as an orgenisation carefully riorkod out and sully stafled, rith offlcials at tho contro and in the ohiros.

1. Tho subjoct of rosorvos of treagure is an obscuro ono. There rero "the king's coffers", apparontly in tho chargo of such household officials ag Thomas Honnoage (L.P. Xiv. I.937; $\Delta d d .1284$ ) and Anthony Donny, both of Thom rocolvod wonoy for tho king'a colfore from the troasurer of augmontations (L.P. Xili.II.457; Iiv.II.236; sviii.II.231), but 
Each of them riec considorod incopondont in itooif, boint rooponsiblo for tho colloction of a cortain part of tho king's rovonues. But thoy rore oll to roport to ono nuthority, to cromoll, and their surplusoo woro to be poolod at tho contro, under Cromioli's control, to bo unod for curront expondituro cind a. roserves.

In this schowo wo can soo what ras, in tho loot rooort, Cromoll's policy for the financial administration. Tho collection of the king's money was to bo so organisod that certain officials rore rosponsible for cortain ooctions of 1t. Expondituro, howover, rao ritictly controllod by tho winlater rho rould use any of the departmonta as ho pleasod. Cromell had found an organigation consigting osoontially of three departmente. Ile hod added tro more, and had at the oame time made dooper and more pormonent the cloaragoo botroen them. He had, in other riords, organisod thom more lully, making thom more buroaucratic. Furthormoro, he had rootored unity to the structure by tho fact of hio om porsonal control which affocted all dopartwento. Though somo Fere more immodiately under him than othorg, oach dopartmont ras rosponsiblo to hin for certain revonuos and put at his dioposal cortain rosorves of monoy. At tho timo, tho most

thoy boom to havo beon, in tho naturo of things, undor tho king's control and aomorhat informal in charactor. Thooo treasurios asoumod roal importanco oniy aftor Cromioli' fell. 
important foaturo of hio organioation was this koyatono of hio own porgonality. IThon that foll confunion rolgnod oupromo, and the royal Iinancos collapood in ruino. Horovor, tho oystor which he had built up undor himolf could, and did, ourvire oren the shock of losing tho waotor who garo it lifo. Tho dopartmonta continuod to oxlot, tho oyotom of dopartmontal courts 70 surthor olaborated, and tho roano roro roady to hand whon tho financial administration ras again roducod to ordor by Finchootor and Burloigh. 


\section{Chaptor 4.}

\section{THE CLERICAL OROANIBATION.}

\section{The 8ignot and 81gnot orifice,}

On 20 July 1534, a for monthe after ho had entorod on the cecretarysbip, Cromell lecued ordors for tho regulation of tho elgnet office. ${ }^{1}$ These rere concerned, first of ell, with the clerks' attendance on the kine and cocretary. Tro of them were to be on duty every month, beginning with Thomas Derby and Filliam Paget on 1 Luguet, to bo Lollorsed by Thoma Friothesley and John Godcalte in Septeaber. "Acording to the olde ordre and custume reedo hertolore in the oald office," they were to exploy themselver in despatching the king 'o busizess, and also in geeing to the furnishing of the king's hall. The foos recoired for the sealing of docusents were to be pooled, and one of the clorks ras to be appointed to recoive them. Clerks not on duty rere not to interfore with the rork of those rhose turn it was and who wero to have "the adveuntage" of all writing to be done. All documento pessing the signet were to be rogietered in a opecial book by the clerk in attendance, and at the end of the month the total thus onterod was to be used in ostabliohing tho oharo of tho oealing

1. P.R.0. DI 42/133, 11.1-17. CI. App. A(IV). 
Lees due to each clork. Tho clorks frero to goo to it that no usauthorised porson did any oriting in tho king'g hall, and no lotter was to pase tho of gnet rithout bolng examined by one of them who wes to olgn his name on the document as proof of his examination. Finaliy, it was appointod that at tho ond of orery month the incoming clerko wero to attond on the oocrotary to recolve their oharo of tho foes, and that thoy rero to take up their dutieg on the firgt day of their month.

Not all these rules wero new, but mhothor Crownoll inventod thew or was werely trying to re-enact eotablishod curtomo, hio ordero indicato how ho intendod the organloation of tho ofgnot office to rork. Looked at from thio point of vier, they lall into tro catogories. Firetly, there are those that deal with the clerks' dutios. A duty rooter is to bo carolully odhorod to, and clerko aro prohiblted from rorking for the olgnot during their month off duty. The resson given for this is finenciel: tho clorks on duty are not to be cheated of the writing 1000 which rade up tho better part of their income. Perhaps the gawe reason was behind the order that no outelders fere to be ellowed to write in the hall. It was 8l80, howerer, e polnt of efficioncy to organioe tho otaff in ouch a manner that oome clorko should alwayo bo arailablo for extraordinary dutleo while the routine rork ras not neglected. A oimilar caro for efliciency was ohom by the order about the ofgnatures of 
examining clerks. Becondly, we Ilnd Cromwell concornod with the foos taken in tho offlco. A coroful diotinction 18 made betroen writing and oesling lo00; tho formor go to tho clork who did the actual witing, whilo tho lettor aro to bo put Into a common pool. The last order combinoo thooo two aspecto: the taking orer at the and of tho month 10 to bo combined with the peying out of each clerk's share of tho oouling Loes. Cromsell's direction showo that he wlohed to organioe in the interests of elflclency, and also to protect the clerke and reguleriso their takingo.

The signing of documents by the clerks reoponoible for meir preperation was no new ldea. It ras usual by the rolgn of Edrard IV for signet letters to be thus olcned, though the eignetory might be the oecrotary, or an underclork, in placo of tho clerk himgell. Aloo, lotters to tho chancory remsined 88 a rale unsignod while those to the privy 8001 wero olgned.2 Ey the tine of Cromirel's prodecessor, both clasege of documente rere normelly eigned. 3 on the other hand, wany docuwento to which the signot ras affixed rent rithout a clerk's 8ignature. This applios in particular to tho many warranto and letters under the olgnot and oign manual which aro otrom

1. If a clerk'g servant rroto the document (as is contomplated in the If th rule), his master prooumably took tho 100 . 2. J. Otray Ruthren, King's Socretery, pp.261.

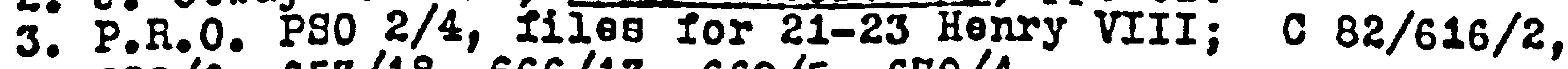
$629 / 6,653 / 18,666 / 13,669 / 5,679 / 4$. 
orer the flles of chascery rarranto. It may be oupposed thot a bill olgned by the king was oufliclontly authorlaed, or porhapo it was thought impertinent for a clerk ostnor to anticipato or to endoroo a royal olgnaturo. Yot eron thlo practice io not without exception, and a olEnet bill 18 occasionaly found with the olgn manual in tho top left-hand cornor and a clork'g oigneture in the botton right-hand corner. One 11lo of chancory Farranto, for inotanco, contains two olgat bilio with tho olgn canual and a clerk'o olgnaturo, authoriolng tho losuo of a congé d'elire and of tho royal assont to the election of an abbot. 1 In the same file there are threo other documente for the oame purposes which are identical with those firat mentionod orcept that they lack the clork'o olgneturo.2 All thooe warranto are wade out in the form proper for olgnet warrants, with tho address on the outgide and the hoading "by the king". There

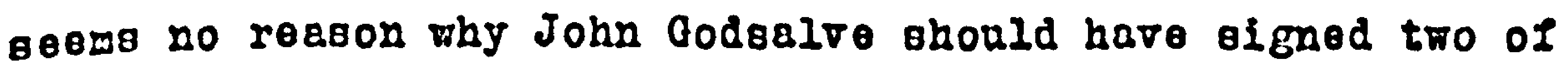
them and not the other three, and in all probability Ihere was no resen. Cromrell'o order tried to make a general principlo out of a normal prectice, and ho ras very largely oucceseful. signet warrente, both those to the privg seal and those to other departments, wore almayo signed after the date of Cromwell'o ordinance, though it wust not be oupposed that there had been much irregularity belore. Tho exceptions which have 
boon citod pero apparontly confinod to documento rather difsorent from the routino work of ombodylag potitiono in lottore under the oignot.

The intorooting 1dea of a tour of duty appoaro to hore been nerr. The ordero roro givon on $20 \mathrm{July}$; tho oyotem rao to come into operation on the firot of tho following Auguot. It was deocribod, not as a gonoral principle, but with opocilic relorence to cortain namod peraono, and wontion was oron mado of the advanced ago of Henry Conway which ronderod it nocoobary to join tro clesko with hit, the throe to be conoldered tro lor purposes of organisetion. All this auggesta that wo havo hore an ad hoc enactwent. Sowo ouch organlogtion wao highly doolrable, if only becauso pignot clorks rero certainly not usod oolely for their routine dutieg, the writing of warranto to the privy beal. It was as well to havo some of them froo frow these duties and erailable for other tasks, ouch as the writing of the king's correspondence and tho drafting of councll and perliamentary businese. Noreorer, the growth, about thio time, of a group of writing clorks will hovo mado tho conotant attendance of all four signet clerks unneceseary. ${ }^{1}$ But howerer

1. It is rory difficult to doduce anything from tho handrriting on olgnet warrante because clericel hande in both the signet and the privy seal officeo varled very little. It 18, hopover, cortain that vo ind in our period both warrents apparently written by the clork who olgned them, and warranto written by someone elos. The namos under a warrant are alraye gonuine signatures, like thoso on privy oeals and unlike those on chencery documento. 
desirable it may have boon to come to oome ouch arrangement, the order rao not carried out properly. Fer olgnet varranto ourvite for Cromeli's tire, 1 but additional information can bo obtalned from the larger number of potftiono proconted to the king, olgnod by him, and used ao diroct warranto to the prify oeal and chancery. A number of these rero ondorsod and datod by the elgnet clerk on duty who sent them off. A bundle of such potitions ohows that Hriothosley was on duty during certain monthe when by the regulatione he should not hare beon. He geeme to have adhered to the rooter in 1534 and 1535, but wao, for instance, endorsine documente in June 1536, not one of his zontho. After that, hio attendance on the algnet conotently broke the rule.2 The chancery 11les, too, indicato that the ner regulations were only at firot obejed. Thus Paget was on duty in Fobruery 1535,3 and Goddelve and Friotberloy worked in Larch and Lay 1535,4 which accorded with the rota as laid down in July 1534. But Wriotheoley appears aloo in October 1535, which marke a break in the oyotem, 5 and when we lind Godoalre endoreing petitions in April, May, June, and July 1537 we mot

1. There are none for the prify oeal and ten in the chancery 11100.

2. P.R.O. PSO 2/4. All but lour of the thirty-four documents in the 11lo-10r 25-29 Henry VIII are endorsed by Mrlothesley; one beare Godsalre's oignature, and threo aro not endorsed at all.

3. P.R.O. C $82 / 693 / 25$.

4. Ibid. $694 / 12,698 / 11$.

8. IbId: $703 / 7,8,9$. 
conclude that tho duty rooter had boon abandonod.1 The rooson

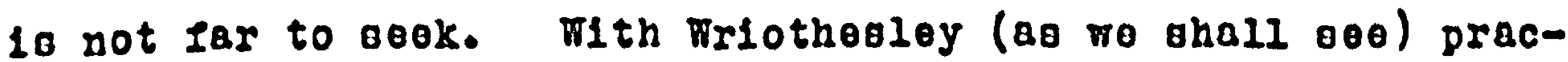
t1cally doing tho rork of an asolotant oocrotary of otato, Derby appolnted to tho clerkehlp of tho council in 1533 and active 80 clerk of the priry council in 1538, 2 and Paget aray on embaoolea Lor a great part of the tiwo under rovion, 3 the routino rork of the offlce had to bo done by rhoorer happonod to bo arailablo. In practice thio meant, in particular, Qodealvo. On tho wholo It rould thereforo oeom that Crommoll's order ras adhered to for a year or 80 and had then to be given up bocause tho multilarious employments of olgnet clerks mode it imposeible. However, the ldes of such a difioion of labour ourvived, being in 1tgell reasonable enough, and in 1537 tho clerks themoolver decided to cone to a permanent arrangement. By then the rork which actually fell to the ohare of a clerk of the olgnet had drindied to such an extent that it was oufficlent to hare only one of them on duty at a time to supervise the writing clerks. Congequently every clerk was to do only threo montho duty a jear in attending on the olgnet. 4

1. Ibid. $727 / 40,46,728 / 18,23,31$.

2. Cl. A. F.Pollard in E.H.R., x258il, pp.3501, and belor, pp.418\%. A successor to Derby was not appointed until he actualiy left London to take up the clerkship of the council of the vest (L.P. Xiv.II.435[2]), while bolore that ho had apparontly maneged to combine the clerkship of tho olgnet with that of the council.

3. CI. D.Li.B., X7.60.

4: F.U. G. Evans, Principal Secretary, p.198. 
The problem of oignet rogiotero 10 complicetod by tho firo of 1619 shich deatroyod noot of tho oarly olgnot and prity ooal rocordo. ${ }^{1}$ Like tho privy goal offlco, tho algnot offlco novor mado enrolmento, but it soomg to hare kept warranto and dockets 89 early as the flfteonth century. ${ }^{2}$ There surrivo no rogioters earlior than Cromall's order, though thio 10 no prool that none vere kopt. On the other hand, tho phraning of his order ${ }^{3}$ euggeste the introduction of a ner rule. Only documento actually soalod were to be ontered; unless thoy woro oealod they fere not, of courge, logued, but wore lmportant then this sooms to haro boon tho fact that oome ouch rocord was neceosary if the sealing foes wore to bo poolod for diviolon at the ond of the month. The keoping of a regleter was theroforo considered necossary becauso of tho difision of labour and the details about lees which rere laid dorn in other parts of the aome direction, that lo, it was an additional order emerging from Cromall's other orders. For that reason wo think that it rery likely conetituted an innovation.

Although no elgnet regiater ourvives for the period of Cromell's secretarjohip he himgolf, very oarly in hile caroer, poseossed a book of all docursonte which had paseod that seal "gince the olgnet came to wy hand". 4 It is theroforo probably

1. Ibid., p.199n.

2. J: Otray Ruthren, King's Secretary, pp.1111.

3. For which C1. App.A(IV), $p .468$.

4. Le. $\nabla 11.923(x x=v)$. 
thet this port of hie ordorg tro esrriod out lmodiatoly. Tho earliogt reglotor Fhich wo posgoon 1.0 that of Ralph sadior which bogins on 1 April 1540.1 Tho koopling of roblatoro bocamo oooontiol at that dato rhon two oocrotarios rero appointed, oach of whom ras to know rhat pesood tho othor'o olgnot.2 Porhapo the signet clerko began only then regularly to reoord tho documonto thoy dealod. All that io cortain 10 that Cromoll wibhed to add tho kooping of ontry books to the organiastion of tho signot offlco, that ho hiwoela had among his paporo a book of writingo ooglod with the olgnot, and thet ouch rogioters rero kept by his ouccossors.

something of a problew is ouggestad by tho vory book in wich Cromell's ordero for tho olgnet offlce are prosorved.2 It contains a mixturo of things. The elgloal is cororod with attempts at the oignature of John Godoelve, one of the clorks of tho signet, and the book is nearly all in bis hand. Cromnell's orders are followed by coples of grants and tho Iike (11.3-16r), the first tro of which are headod in largo lottera "De indigena lienda pro oxtranoo ot liberlo" and "Aliter do Indigena pro extraneo liondan. Somo othoro aro Biten marginal descriptions, as "Llcencia", "Monrogid", "Plea", "Prosontacio". In many cases the granteo'o name is given by initialo only, and

1. B.LS. Add.uSS 35818.

2. Ci. the rarrant of their appointment, L.P. 28.437.

3. P.R.O. DL $42 / 133$. 
the dating clauson aro not transcribod. Th1s ooct1on 10, therefore, not a book of coples kopt for record, but a procodent book. Hany of the docursento to which tho entrios can bo ohorn to refor woro logued a ohort timo beloro Cromoli'o orders. Thus we have the denlzation of Luke Hornbolt, the paintor ( 1.4 ), of 22 Juno 1834, 1 Chriotophor Mount'o annuity (1.12) of 26 Juno 1534,2 and the rardohip grantod to Thomad Fentworth $(1.12)$ on 13 lay 1534.3 It followa that somo of the entries rero made at tho oamo time as Crommoll'B ordoro nere entorod, tho forwor having perhaps boon tranocribed from an earlier book. Then Godoalve mado up hio privato procodent book be rould naturaliy prefaco it with the latost departmental ordora. The preoodonts are followod, after a for blank pacos, by a regieter of documents signed by the king, with notos of delivery to verious recipients and covering tho poriod from 9 January 1541 to 30 Septombor 1543 (ff.23ff.). Thio part 1o clearly the regloter of an individual eignet clerk. It does not contain only documents oealod and paid for, for petitions presented to and signod by the king come vithin 1 to scope and these were not sealod. While it io not, therolore, exactly the kind of regleter whlch Crommoll envisaged in hio orders, It is evidence of the semo desire for the koeping of records.

1. L.P. $\nabla i i .922(14)$

2. Ibid. 922(25). This is annotated "delyuered to Lr L'os 8oruant the xjth of efobruarij".

3. Ibid. $761(20)$. 
The rory lact that 1 tras kopt on the loares of a procedent book Indicatos that it was not Godoalvo'o I1rat book of ontrles; we may ouppose that he used theso blank leaver whon he had filled his earlier regiotor.

The other orders could not by thelr nature loare any traco behind them. Horerer, together with those that did they ohor that in organiaing the algnot office Cromrell was particularly concerned with 1to elficiency and with the falr distribution of the foes collectod there. His ldoas boro frult, oome of them possibly at once and othero later.

Another attempt was made to organlise the bureaucracy during the time of Cromrell'o minlatry. In 1 to $1535800810 \mathrm{n}$ parliament passed "An Acte concernyng Clorkes of the signet and Privie seale". ${ }^{1}$ Cromell's responalbility for this act cannot be proved conclusirely, but it can hardly be doubted. Por one thing, the olgnet wae hio particular departmental respongibility; for another, it is easily ohorn that parllamentary legislation was almays one of his chlef concerns, although that is too large a themo to be dereloped here in detail. The oridence lies in wany an entry in his remembrances and in the multitudinous corrections which he mado in the drafts of bills, and it seoms pormisuible to argue from a known general interost to a plausible particular one in thlo instance ohich concerned

1. 27 Honry VIII c.11 (stat.Reglm, 111.5421f.). 
the oecretary'o proper ophero of action. Tho care becoreo mach otronger otill when the tormo of the act are considered. Aftor a proamblo otating that clorks of tho olgnet and prify ooal had no wages excopt tho profito of tholr labours, and that it was dosirable to provent bheis being choatod of these, it was enactod that from 15 April 1536 no wanner of writing was to pase the great sealo of England, Iroland, tho duchy of Lancaster, and tho principality of Malos, or by procers out of the exchequex, unlese it had firot been examined by the king's principal oocrotary or a clerk of the gignot. Within eight days of receiving a rarrant oigned by the king, the master of the warde, the general ourveyoro, or any other rojel officer, the clork of the elgnot was to make out a warrent to the keeper of the prify seal, ouch rerrant to be subgcribed by him and to bo soalod with tho oignet. Fithin oight deys agsin, the clerk of the privy oesl was to wake out his warrant to the lord chancellor or other offlcor whose province 1t was to carry out tho ingtructions. Tho ponalty for making marrants differently was to be $£ 10$, half to the king and hall to the informer. Immediate rarrante rero permitted for oxceptionel caser, but fees wore otill to be paid to the signet and prify seal on pain of a like line. Provisos excejpted oomo routine or minor matters, and a acale of 1008 payablo to tho clerke of the olgnet and privy oosl for the riting of documents 
was lald dom. Hero again a penelty of 110 wao impooed on any clerk taking higher loog. Finally, thero roro oome more proV1800, the most important of which permitted the lord chancellor to remit the fees of ald threo ooals "0o hath bon accustumed". Thore are threo pointe in perticular which oupport our vier that Cromell was bohind thio act. Tho king'g principal oecretary io given a opecial mention, in tho oamo tono of importanco as that ancient offlcer of otate, the lord prity ooal, and who would be more likely to authoriso thio then the oocretary himgelf? Wore important is that tro of ito proviolons link the act with Cromoll'o regulationo for the oignot offico! the order to the clerko to oign their warranto was ropoated, and the scale of leos oupplewentod his directions concerning the payment of oignot clerks. Wo think that Cromroll $780 \mathrm{di-}$ rectly responsible for this act; that ho conceived it and oupervised ito drafting; and that ito torms reflect his mind. But if it bo thought that this is too mach to claim - though it Io not apparent why it should bo, in vion of tho general agreowent on the point of Cromell's oupromacy in the gorernment of England - this at least will have to bo admittod: tho act ras in agreoment with what wo know of Cromoll's plano for tho olgnot office; tho oignot was Cromell'o porsonsl concorn; and legiolation 780 ono of Cromell's chief intoresto. It Lollowa that we may seo Crompll bohind the act, ol thor as an 
approring onlooker or - what Booms much more likely - oo 1 to outhor.

Howeror, there was an earlier form of the act. A draft ourvives, much longer and more dotalled, and of th some esoontial differences from the final shapo of the act. ${ }^{1}$ That it is a draft prepared for that particular act and that particular sesolion is proved by the goneral agrooment of the proviolono and by the mention of the dato on which it was to come into operation as 27 Henry VIII (April 1535 to April 1536), with the day and month left blank. Thero must hare been another, later draft, for the ocale of foo, which mentiono the oame kinde of documento as the act itoele, leaves blanko where the arounts ought to be. For the same reasons as those stated abore re mast assume that it was dram up with Cromell's knowledge and proliminary approval. The fact that changeo wore zade and the character of these changea can, on the grounde shorn, have beon due only to him.

The biggest difference 18 in the preamble. This really eettles the question whether the 1535 act establiohed a ner course of "officfal channelo" or merely gave statutary forco to a customary practice. It has been known for some time that the rale by which every grant undor the groat oeal passod from olgat to privy ooal to chencery riag laid dorn at loast ao oerly

1. P.R.0. SP 1/101, 11.292-302. Lioted in L.P. $x_{0} 246(5)$. 
as 1444.1 But Cromroll'o act oxtondod thio to all documonto paoging tho privy ooal on thoir ray to othor dopartmonto of otato. Horoover, it has boon doubtful whothor tho counc1l ordinanco of Honry VI had boon oboerrod and rao moroly boing re-onactod, or whethor tho ralo had boen forgotton and rao otated afreob in the otatute of 1535.2 The proamblo of the draft wakes it plain that the oyotom of 1444 rao oupposed to bo in Forking order, and that the authors of tho act know thomoelvos to bo but conflrwing an oldor practico which, howoror, res not boing rell obsorrod. Tho statute ras noceseary, thoy stated, bocause of late wany "mallcious, lowdo, and crafty peroong" had managod to commlt iraudo by exploiting tho nonobserrance of the established rule.

The draft further declared that the kingo of England had norotoforo ostablishod that nothing obould paso thoir groat coolo or out of the exchoquor by rray of lovying of forfolturos or paymont of pheriffo" rowards rithout "furat boyng examymed by their principall Socrotaryce as poroonages mooot nero of their moost honorable counsaill end rinich by dayly and contymarl Fier and sight ought begt to knowo tho true caractos and signes of thoir moost noble hendeg". 3 Tho oocrotary was to give the Farrant olgned by tho king to a clork of tho oignet

1. Lastill Lyte, Groat Seql, p.30.

2. F.L.G.ETang, Principel Socrotary, pp.19511.

3. P.R.0. SP $1 / 101$, II.2928-293. 
who would koop it and wito a warrant to tho lord privy ooal. Eo in h1s turn would examino tho warrant and lesvo it with a clerk of the privy oeal who rould wake out a rarrant to tho chancellor of England, Iroland; or the duchy, of to the troaourer and chamberlatno of tho exchequor. Tho procoduro ras therefore horo set out at greater longth, with dotallo rhich prove that the secretary and lord prity soal roro oxpocted to carry out their departmental dutios in person. The opecial releronce to the secrotary's otanding with council ${ }^{1}$ and $k i n g$ 18 interesting; it addo another and otrongor proof of Cromwell's concern in thio leglolation, and it also showo that ho ras rell arraro of the two outstanding adrantages which the gecrotaryohip gero to ito holder. It was as tho ooveroign'o confidential servants and as the controllero of the (privg) council thet the Tudor secrotaries eotabliobod their porior.

The body of the draft did not differ greatly from the act as passed. It included a opecial provision prohibiting all unauthorised persons from waking any writing by warrant of the king's"sign manual and from procuring the passage of ouch document. This remindo us of point ilte of Cromrell's orders and again links hio name pith tho act. Chancery clerks pasolng a grant by immediste rarrant wero aftermardo to obtain

1. "Moost honorable counsaill" is a phraso that mat refer to tho council as a body, not to counsel as a pioco of advico and moening deliberationo. 
tho uonal oignat and privy ooal warranto within throo montho. The poriod in which clerks of tho oignot and privy ood roro to ect after rocolving thoir rarranto was givon as ono wonth in tho draft, ingtoed of tho ofght dayo of tho act. Apart from minor changes, tho wain altorationo mado durins tho roFision of the draft touched, therefore, tho anglo from rhich the problem rag viewod. The draft intonded to abolioh fraud and abuse, and was wainly concornod with organiolus a loolproof buroaucratic syotem. Almost as an afterthought, and with a special brief preamble explaining how desirable it wao for the clerke to get an hone日t living from thelr rork and for ouitoro not to bo orercharged, tho draft appondod a ocalo of foes. In the erent this became tho central point, and tho act rag ostensibly peosed in order to assure the clorks of their selaries.

Horerer, whilo thio different attitude io manilest and ofgnificant, it most bo odoltted that in offect both draft and act did the same thing. The act of 1535 rao quoted ever after not because it osfeguarded the interegto of the clerke of the oignet and privy oeal, but vocause it gave otatutory force to the established order of meking a grant under the great oesl. It did this, on the lace of $1 t$, in order to prorent poople from ovading the feos due to the clerks by taking their signod billo straight to the chancery, but tho draft 
maleos it plein that adminiotrativo offlatency and the provantion of Iraud 7oro at least as much in the mindo of the framora of the otatute as tho payment of foos. In all probability it was thought wiogr not to confront a parliament which undoubtedly contained many who had at one time or anothor profited from imwodiate warrante with a statement that they rere "maliciouo, lezde, and crafty peroono" who, if they had not actually lorged the king'g sign wanpal, had boen the cause of "manyfold other enorwities [and] inconveniences". Hence tho ohifting of the exphasio. The alteration which reduced the tiso allored to a clerk for writing hio furthor warrant to a quarter of tho time originally granted was obviously in the intereate or the suitors and may have beon made to placato opposition. It also, of courge, adranced efficiency. Thus the tro begic ideas of Crombell's act - reform of the bureaucratic organioation, and protection of tho intereste of tho civil service - were the game 8 those of Cromell's orders to the signet office. These rere the pointe with which he $7 a$ most concerned in his dealinge with the clerical oide of the adminiotration.

There is one other characterietic mich theoe tro documente neve in combon. They are both interested in the signet only as a atage in the process by which documents rere lsoued under other geals. ${ }^{1}$ They are not concernod with the oignot in ito

1. The same applies to the privy ooal as treated in the otatute; for this cf. Soction II of this chapter. 
Indepondent exlotence. All the talk about writing and ooulins Lees could only apply to docussento in the buroaucratic chain, for when the olgnet was usod for authontlcating tho king'o privete correspondence no foes rould, of course, Lall duo. The act is oven more obriougly concerned with the olgnet only as the first of the throo ooals under which documenta had to p8s8. This may be due to the fact that the algnet had coasod, or noarly coased, to bo usod in an independent capacity. On the other hand, it may merely mean that cromwell directed his organising activitios to that part of tho rork of the olgnet office which was moot obviouoly organioablo and in nood of organisation. Fich of these anowere is the correct one can only be established by an investigation of the oignet in botb capscitios, during the time of Cromoll's government.

Firet, then, the ofgnet as a seal of warranty to other dopartmente of otate. In theory all grante under the great geal required a olgnet warrant at an early otage in the procredings; either the procese ras started by such a warrant, or one ras made out on the basis of a petition approved and oigned by the king. Such petitions are technically described as algned bille, but as that term included other documents oigned by tho king and used as warrants, we shall hore rofor to ther always as sigmed potitions. If tho theory rore right - the theory, that 10, of the proamblo of the draft quoted 
abovo - 70 should expect to find the rarrants for tho prity oeal to conoist largely of marranto under tho olgnet, oven before the act of 1535 gave otatutory oanction to tho procodure. We should certainly expect ouch rerranto after 1535. Eorever, the extant warranto for the privy soal tell a difLeront otory. 1

For the year 21 Henry VIII (1528-9) we have one flle of efghty-tro documente, for 22 Henry VIII one of elxty-11ve, for 23 Henry VIII one of trenty-one, and for the yeare 25-29 Henry VIII one of thirty-four. This already indlcateo that the records are incomplete; the years 24 Henry VIII io misoing, and the others are nothing like complete. To give an example: there are among the chancery warrante 196 privy oealo for the year 25 Henry VIII alone each of which should have a corregponding rarrant in the prify oeal 1iles. Nevertheleso, even in their fragmentary atate they can tell us aomething. For one thing, we notice a rapid decrease in the numbero and regularity of the documents preserved by the privy seal as wo approach the time of Cromell's secretaryship. Eren more auggestive is the composition of the files. Of the eighty-tro documente in the first file, fifty-gix are rarranto under the olgnet. In the second ille, the proportion io forty-throo out of sixty-iire, and in the third airteen out of twonty-one.

1. The warranto for the roign are in P.R.O. PSO $2 / 4$. 
In genoral torse wo may thorofore oay that tho privy ooal could expect about tro thirdo of 1 to rarranto to be oonlod with tho oignet. The fourth 11lo, which containg what rovalno of tho porlod of Cromell's oecrotaryohip, dooo not provido ono exarplo of a genuino algnet rarrant. There aro throo olgnod billo gealed olth tho signot (nos. $7,17,18$ ), but oven they affer Irow othero of their kind in boing endorsod with the dato and place of issue by a ofgnot clerk. Othorriso the file containo only olgned potitione, forrorded as parranto and ondoraod with a note about thoir being deopetched to the prify ooal, with date and place. Theso notor aro all ofgned by, or in tho hando of, signet clerks. Before Cromell's tiwo the formarding of gigned petitions as rarrants for the prify seal only had boen so unusual that but one survires in the 11100 analysod. ${ }^{1}$

For the last tro years of Cromell's tonuro of ofifce no zarrants are presorvod at all. But with hio fall and the appointment of the earl of Southampton as lord privy soal a groat change comes over the ffles. From June 1540 onwards pe find wonthly bundles, usually with covering notes signed by cloriso of the prify seal, of rarrants under the of gnot, and nothing elge. Irom that moment, thorofore, the rocorda asoumo tho appearance which wo should expoct from a thoorotical knowledge of the procedure.

1. File 21 Benry VIII, no.119. 
It 18, of couroo, pojolblo that all thooo facto aro merely the rooult of the acoldental preservation of oomo records and deatruction of othera. However, that rould bo to auppove too large a rorking of colncidence. It geoms to us that wo haro bero something like a true picturo, a littlo diotortod porhapo by the oboence of what lo 20ot, but yot ossentlally corroct. It gooms 1088 incredible that thero woro very for olgnet varrante for the prify geal from 1534 to 1540 , than that juet thoso narrants ghould be lost when 80 many were proservod both before and after that poriod. Fo thorofore oubmit that the records enable us to drap some conclueions which are most likely correct, though in vier of tho ovidence on vinich thoy bave to be based an element of doubt la bound to remain.

It appearo, then, that the oignet practically coased to be used as a seal of warranty to the privy ooal during Cromrell'g supremacy. The olgnot office continued the practico, begun in the last year of Gardiner'o secretaryohip when Cromwell was ofton deputising, 1 of forrarding the of gned potitiono received from the secretary direct to tho privy seal, and it ras the rule that the oignet clerk carrying out this duty should endorse the petition to that effect. ${ }^{2}$ At the same time

1. Above, pp.1021.

2. Tho fect that the illo preserved at the privy oeal offico contains almost only documents doalt mith by Triothosloy doos soo - to be duo to an accident of preaervation. Signed petitions which got as far as the tiles of chancery rarranto are ondorsed also by othor clerko of the olgnot. 
ouch carologaness prevallod about the kooping of warranto that none at all survive for the botter part of tho porlod when Cromell was lord prify ooal. And all thig happened at a time when it had only recontly boon onacted by parliament that tho traditional routino should be carofully observed. Thoro can be only ono explanation: the peroonality and pereonal government of Cromell. In chargo as ho was, and in otrict control, of gignet and prity seal, be found it unnocooary to ingist on a careful adherence to the dotallo of the bureaucratte process. That counted, as it oo ofton doos in a gororniont dominated by one man, rero efficiency and opeed, and not the letter of the lari.

In vier of these facts it is interesting to recall that when the act of 1535 ras drafted the emphasis shifted from administrative efficiency to the interests of the clerks of the signet and prify seal. The ohort-circulting of the normal procodure, which tho absence of varrants indicateo, did not oare suitors from paying foes at orery stage. That had boen expressly laid down in the act, ${ }^{1}$ and the provision was carriod out, though the proof we can givo datos Irom after Cromell's 1al1. A algned petition delivered into chancery on 2 september 1540 has on its dorso a briel lettor from a clork of tho olgnet to a clerk of the chancery, asking hin "to passo this byll by

1. 27. Henry VIII c.11, sec.4. 
this warraunt, recoyping the flood for our offlce and tho priJie seale for the same". 1 a wan whooe grant pesoed by direct rarrant rould therefore pay a furp oum into chancery, and the olgnot and prity ooal rould dran thoir oharo from there. The ootenolble prepose of the act ras therefore not offended by the practice of cutting dom tho adminiotrative procoso. There ras no insiotence on the regular routine. signet clorks Fere Ireely employed on other rork, and tomporarily the olgnet was rarely used in ito function for authoriaing lettoro under the privy geal.

That this was due to Cromsell alone is cloar from the oudden reversal of the practico after hio fall. The groat minioter with his hand in and over nearly every department could dispenoe with the detallo of a process which rao designed to preront fraud and safeguard the interesto of the civil service. His successors took no such rioks, and when Cromell fell the oystem for which he obtained the authority of parliament res at last put into full operation. It was not rorked out after him, for it appeared fully grom imodiatoly aftor hio fall. secretarieo Wriothesley and Sader could inaiat on the writing of rarrants inatead of the forvarding of potitions, and lord prity seal southampton could have them carelully liled, only because the whole system had already been organised in thoory

1. P.R.0. C 82/772/2. 
by Crompoll. As in hio inancial adminiotration, 00 in hio dealings with the bureaucracy, cromroll ras moved by a doublo deoire. He ranted organisation for othera, and he ranted the fullest freodom of action for himeolf. Fith hlo fall tho man1festations of the socond dealre naturally dioappoared, but the organigation otood.

The prity seal office was not the only place to which rarrants under the algnet might be directod. Somotimes it would be by-passed. Signet varrants aro found in tho chancory illes, but their number io swall. Hor they reached their prosont whereabouts is not clear. Thon one is addressed to the chancellor it ie, of couroe, obvious that tho prify oeal ras being left out deliberately. There lo one ouch example; ${ }^{1}$ all the othero that we find among chancery warrants aro properly addregsed to the lord prify oeal and ordor him to vrite warrante to the great oeal. Lost - not all - bear tho livery clause, giving tho dato and placo of thoir boing handed into chancery, and are therefore Itled in the correct place. Hone exist for the period of Crormell's tenure of the prify geal, but there are a fer which he counteroigned as secretary. ${ }^{2}$ Thio

1. P.R.O. C 82/653/18. This tarrant of 22 Larch 1532 ras olgned by Derby as clerk of the oignet, and by Edrard Foxe "In aboentia Reverendi domini Secrotarij", Gardiner then being abroad. This may account for the irregularity of sending it otraight to the chancollor.

2. Ibid. 674/4 (undor September 1533 but bolonging to 1534); 681 ) 26,27 ; 688/5; 700\$14 (of July 1534 but not signod by Cromeil); 701/1. 
Indicatoo that wo ought, porbapo, to qualify a littlo what wao aald above about the virtual cosoation of tho olgnot as a ooal of rarranty, though tho omall number of the varranto ourviving eren outalde the prify ooal rocordo learoo that concluol on oooontially untouched. Probably tho normal procoduro wao omployed wore lroquently at the beginning of Crowell'o oocrotaryship, and ito uso docreased as his govornment bocamo moro porsonal and unchallenged. That is what one rould expoct, and these rarrants in the chancery fileo for 1534-5 oupport ouch 3 Dien. Thy some varrents eddressed to the lord privy oeal ohould have-iboin delivered into chancery, wo cannot toll. No angrer is to bo found in thoir subjoct matter. Thoy appoar to be freaks, due perhaps to pressure of pork at the prity soal office, or simply to chanco. They aro not confined to, nor particularly frequent during, tho poriod of Cromold'o goternment.

Among warrante to the exchequer during the $1530^{\prime} \cdot$ there 18 one under the signet. It is dated 7 August 1538, and 10 actually cast in the form of a prity soal. ${ }^{1}$ Horrover, it is "yeren vnder our signet" and oigned by Godsalve, and is theroLore a genuine aignet warrant, which proves that warranto under that seal might be addressed diroctly to the troasurer and chamberlaing of tho exchequer. Ito oolitary otato aloo proves

1. P.R.O. E 404/101. 
how very unuoual ouch a citting out of tho privy boal wao. A ooworhat different otory 1a told by the marrants to tho duchy of Lancestor. Thoro olgnot rarrants appoar to havo boon not uncomon in the oarlier yearo of the relen, 1 but nono can bo found after June 1532.2 Under Cromell, warranto to tho duchy \#ero, with a low excoptiono, of ther aignod potitiono or prify ooado; after him, tho lattor cloarly prodominatod. Tho potitiono may have gono directly from the olgnot office to the duchy, but only one is endorson as bolng thus dispatchod. 3 It io therefore aloo possible that thoy wont to tho prify ooal and Fere forwarded to the duchy from there, liko othor potitions which rent to the chancery. The chancory of tho duchy. ras ono department over which Cromoll'o various offices gave ntw no control. The great declino in tho numbero of warranto "per conglilum ducatus", Which composod the bulk of tho rorrants in the earlier joars of the roign, ouggeoto that Cromoll may havo usod his control oror tho olgnot and privy goal in ordor indiroctly to control tho duchy. But no cannot atray to investigato a ficld somerhat outsido the scopo of the prosent otudy. Genorally opeaking, tho fileo of the duchy indiceto that here, in a departrent tochnicaldy indoporidont of him,

1. Thuo there are trolve in P.R.O. DL 12/11, botroon 1509 and 1515 .

2. P.R.O. DL 12/8/24: a draft patent of 7 Juno 1532, markod "per rarrantum oub Bignoto".

3. P.R.0. DL 12/12, 10080 document of 28 April 1537. 
Cromell alloriod the corroct routino to bo follorod, thet is to oay, ho sam to it that duchy ernnto rore authorlood from tho privy soal offico. Diroct offnot rarrento thorolbro dioappoarod.

A lest cless of rarranto under tho olgnot wast bo conolderod - rarranto authorloing oxpondituro by offlciolo of tho bousehold. These aro rathor difforont erom the normal olgnot warrant, inasmuch as thoy havo tho addrose ritton on tho faco of the documont, are not signod by a clork, and aro nignod by the king. Te have alroady montlonod the rarrants to Cromroll as Eaoter of the jorols; $;^{1}$ similar farrants roro mado out to tho keopor of the great vardrobe,2 the great mestor of tho housenold, 3 the mastor forester of the foreot of Findoor, 4 and no doub: to others. In lact, expondituro of tho king'a troasuro Fes usueliy authorised by rarranto under tho olgnet, though tho elng'o olgnature 78 aloo roguirod. The posoossion of tho olgnet therofore gave Crommoll a further moano of controling oxpondituro. Unliko rarranto to other departmonts of otato which kept recordo, those rarrente to individual orficorn havo retarally fallod to ourvivo excopt by accident, and it is thus imposible to say what exactly Crowoll'o practice rao concer-

1. P.R.O.E $101 / 421 / 5,9,20$.

2. Ibid. $420 / 1 ; 418 / 1$, a bundlo of twenty-tro marranto to Andror lord Tindoor, keopor of tho groat rerdrobo.

3. B.H. Af . LS 9853, 1.210 .

4. Ibid., 1.847 . 
ning thom. Wo knor that ho obtalnod rarranto to coror paywonto male by himoll, and that tho troacuror of tho chambor Inolotod on thom. 1 Ho havo aloo ooon that tho troagurer of ifrot Iruito and tontho had to dioburco monoy rithout rarranto end corplainod about it aftor Cromoll'o fall. 2 on tho rholo, It oeoms that theso rarranta, sealod and probably writton by olgnot clorks and thoroloro part of tho work of tho olgnot office, wero isoued as irooly under Cromoll as they noro boforo and after him, oxcopt in tho eavo of tho troasuror of firot fruita fhom Cromoll treatod rory mach as tho pornonal oervant that he ras.

Those varranto, which orderod action and not a furthor rarrant for action, bring us to the socond group of documento losued under the oignet. It was tho soal with which the king's corroopondence $\pi \varepsilon 8$ sealed. If we take the oridence for tro ropresentativo yoars, 1534-5, wo find that the ling narmally corresponded under the aignet. There aro in that period twonty-threo lettoro which roro cortalnly thuo soaled. 3 Iformally, they were what might be tormod propor olgnot lottors: witten by a signot clerk, with a dating clauso montioning the cignet, headed with the phrase "by the king" and Henry'o oig-

1. Above, pp.19611.,2171. 2. Abovo, p.250.

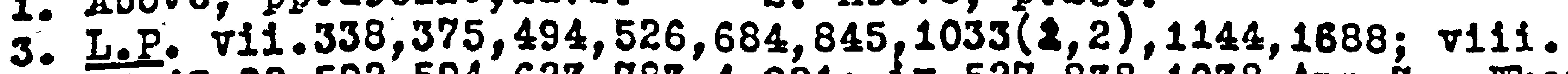
$25,43,92,592,594,623,783-4,921$; $12.527,838,1038$, Ap p.7. Thererer poosible tho lettoro quotod in thio paragraph hove beon chocked rith tho originalo, as the calondar ofton glvos no indication of tho soaling. 
naturo, and addrosood on tho outaldo. Tho king's olenaturo ras somotimos addod by a otamp, ${ }^{1}$ or might bo misoing oron in a lottor which ras dorinitoly oont. 2 In ono caoo, a lottor to Cromroll, tho olgnot 10 not montlonod but rao eppliod and ot1ll surrives. 3 Lottors which rore not provebly oobled with the olgnet are ofthor drafta without tho ifnel clauoo, or bolong to the king'o diplomatic corroopondonce with loreign porero. Wost of thoso lattor are in Latin and writton by tho king'g Latin oocrotary, Potor Vannoo.4 Thooo naturaily had nothing to do fith the olenot offico ao far ao writing Fent, but it is of intereot that Vannos did not apparently bave to got them authontiratod by tho king'o normal ooal. At losot, the signot ras not contionod in thoir dating elauso, though we do not knor hor thoy riero gosled rhon clogod. It is possible that the oignet ras usod, and that the principal oecretary applied it; on the othor hand, the royal signaturo, written oithor at tho top or undernoath liko any normal oignaturo, may haro ouflicod. Prool one vay or the othor is unobtainable. Instructions to anbassadors nont out in tho form of ordinary olgnet letters.5 That sayo nothing for thoir origin. Thoy roro most Iroquently witton, in thooo yoars, by

1. E.B., L.P. $\nabla i i 1.25,43,92$.

2. L.P. $\nabla i 1.684,845$.

8. LE. Viii.592.

4. He counteroigned rome of them: L.P. Vili.522; ix.532.

5. E.g., L.P. 1x.838,1038. Ibid. 443 r8s all ready and olgnod by tho king, but thoro is no dating elauso. 
tho hand which wroto aloo tho additional inotructiono oont orer Cromeli'g namo, the hand of $\pi$ riothooloy. 1 It 10 thuo $11 \mathrm{koly}$ that lottero ribich went ad though from tho king roro aloo propared in Crowwell'o office and submittod to the klas for approval and signature. 2

Tho eridence is olmilar for a later joar whon Crowwell was more fully independent, a fact which way bo rolloctod in the comparatively amall number of lottore sont out undor tho king'o oignaturo in 1539.3 Lettero delinitely given under tho signot rere in Englioh and addresood to poroons rithin tho roalm or to ambassadoro overseas.4 Thoso not so sealed nero all addressed to loreign courto, and rore ritton oither in Latin or in French. 5 It way be concluded thet tho oignet wao aged Iroely, if not regularly, to seal tho king'g personal corsespondence, but that lotters not written in tho olgnot

1. E.g. L.P. ix.838 (tho king's inotructions to Gardinor) and 848 (Cromell's supplementary instractiono oent at tho oame time

2. An Intercoting comparioon can bo modo with the practice under Elizabeth. In Jarch 1562 certain inotructiono roro cent to II cholas Throckmorton, rosident ambasoador in Franco. The original survivog and is a propor oignot lottor (B.L. Add.IS 4160, $1 \mathcal{l} .42-3)$. But there aloo survivos a draft corrected by Cecil and endorood by his oecretary (Cal.3,P. For., 1561-2, no.926); again 70 o00 that whet wao cloarly an ofIicial letter ostensibly emanating from the crom might originate in the secrotary o oflico.

3. Thero aro tronty-threo in tho index to L.P. $x i v$, comparod vith thirty-8ix in 1535 (L.P. vili and $\overline{i x)}$.

4. L.P. xiv.I.92,280,406,487,711-2,744; II.574.

c. Ibid. I. 364, 441-3,462, 1156; II.221, 307, 387, 415 . 
offico did not mention tho oignot and poosibly roro not ooalod Nith it.

Crommoll'a prooccupation rith tho olgnot at a oonl authorising tho losuo of documonto under another ooal ras not, thorefore, due to its boing usod only in that capacity. On tho contrary, wo have soen that it tondod to bo ovadod during hio adoinistration, ond that it ras in lact usod moro regularly ao the king's porsonal sobl. As ouch, howoror, it wao not in nood of formal organisation. Ito uoo enablod Crowroll to control the king's correspondenco, and this control was increased by the regular omploymont of algnet clorko to draft Honry'o letters which quito posoibly ho noter $88 \pi$ untll thoy roro oubmitted ready for his oignaturo. But in ito administrativo function the oignet needed organioing. Cromroll'o ordero and otatuto were designed to establioh a rigid bureaucratic oyotem, though in practice ho paid littlo hood to hlo om woasuros of organisation. He dioregardod the oyotem, in tho interooto of spoed and efficiency, and prosumably bocauso hio control ras tight enough to excludo tho ovilo rhich under a roaker wan only an ordered bureaucracy could provont. 


\section{The Privy Boal.}

Juch of what has boon said of tho gignot good also for tho privy soal. Tho act of 1535 providod for both. It was cromwoll'a clear intention that tho privy sobl ohould bo uood, l1ko the aignot, in tho otrict order eotabliohod by tradition and tho council ordinance of 1444. Ag, in thoory, nothing ahould leave the prity soal unle80 a rarrant undor tho olgnot had boon received, 80 - in thoory - no action ras to bo takon by the chancellorg of England, Iroland, and tho duchy of Lancaotor, or by the treasurer and chamberlaino of tho oxchoquor, unloso thoy had had a parrant under tho privy ooal. Onco again, howovor, It rould be rash to ouppose thet this procoso rao proporly obgervod morely bocause it ras ombodi od in an act of parliamont. The filos of rarrants to tho chancefy contain a rariod asoortment of material. Thero are occanional rarranto under the signot, bills and liato signod by the king, warranto from the lord treasurer, petitions countersigned by tho gonoral ourveyors of tho king's lando, fiats for protoctions olgned by the deputy at Calais.1 By far tho groator part of the marrantg, horovor, aro privy joals and simod potitions, and It is with thoso tro classos that ro wust here concern our-

1. Ono month (Juno 1529, P.R.0. C 82/616) can provido oxaiplos of all theso: olgnet Tarrants - no.2; billo olgned by tho king - nov.22,24; troasuror'g marrant - 1; potitions oignod by tho genoral survoyors - nos.12,13; Iiato olgnod by tho doputy at Calais - nos.7,25. 
oelvos. If the oyotom had boon rorking proporly wo ahould not, of courgo, expoct any signod petitiono but only prify noalo. The chancos are that ovory auch potition found anong tho chancory sarranto conotitutoa an ovasion of tho privy oobl, though it is thooretically posaible that tho privy ooal wight olrapy forrard a potition receivod from the signot offico. But thoro boors to be no reason rhy thoy ohould havo dono bo. Somo of tho potitions ook definitoly that thoy may bo sienod and uood ag direct rerranto to tho chancelior. 1 Ho may take it that normally olgned potitiono found to havo boon doziverod into chancery rere direct rarranto omployed to cut ohort tho cumbersowe process of warrant upon warrant which ovory grant wao supposed to follor. 1 large number of ourh potitions ovor a longer poriod will therefore indicato a largo-ocalo orasion of tho rules, a smaller numbor a stricter adheronco to thom. Starting rith the laot nontho of Folooy's rule, wo find that during ther potitions regularly and oonolderably outnumbered prify seal6.2 In Octobor 1529 Folooy foll, and ro ouddonly lind eightoon prify ocals to tro diroct varranto. 3 Thio proportion io kopt np for a long timo aftor that, with oignod

1. E.g., P.R.O. C 82/646/3: "that this bill signod with your moat gracious hand mayo bo a oufficiont and ymodiat rarraunt vato your Chauncollour of England".

2. Tho figuros, with privy ooalo first, aro: Lay 1529 - 2,18; June - 6,11; July - 3,21; August - 8,13; Soptomber - 4,10. (P.R.0. C 82/615-619).

3. Ibid. $620 .$. 
potitinno almost disapponring in oowo montho and nlwayo in tho ainority. For tho firot yoar aftor Folnoy'n fall, from Novoinber 1529 to 0ctober 1530 , thoro aro 315 privy gonlo and only 36 potitions. 1 Siviler proportiono continuo for throo yoarc aftor, ith the number of petitiono olightly on tho incroaso, but in 1534 thore aro only 178 privy noalo comparod rith 111 potitiono, and in 1535 tho latter astually outnumbor tho formor. In 1536, thero is once moro a conoidorable drop in tho number of petitiona, but for the rest of Crommoll'a goremment thoy are again very numerous. A table will mako thio cloar:

$\begin{array}{cccc}\text { Jo8r } & \text { privy ooalo } & \text { potitiono } & \text { P.R.O. C 32/ } \\ 1531 & 309 & 27 & 637-650 \\ 1532 & 253 & 39 & 651-663 \\ 1533 & 201 & 82 & 664-677 \\ 1534 & 178 & 111 & 678-691 \\ 1535 & 117 & 139 & 692-705 \\ 1536 & 277 & 89 & 706-719 \\ 1537 & 216 & 185 & 720-733 \\ 1538 & 185 & 177 & 734-747 \\ 1539 & 149 & 243 & 743-761\end{array}$

Tho same tendency continuod at first after Cromell's Iall, largoly beeause of tho time lag botroon tho olgning of a rarrant or petition and ito delivery into chancory. That thio ras 80 is ghom by 8 numbor of potitions countoroignod by Cromell by virtue of his commisaion to oell crom lando. He was arrosted on 10 June 1540, yot thore are still four ouch petitions in the fuguet 1110.2 Things took noarly oix montho

1. Ibid. 621-34. 2. Ibid. $771 / 8,20,23,29$. 
to sort thomselves out, and until soptomber potitiono continuod to outnumber prity soalo. But in Norombor tho numborg noro forty and thirtoen, and in Docomber oixty and ono. 1 In tho lollowing year, the nor proportion was otoadily maintalnod.2 These figures toll thoir orn otory. During Folooy's chancellorahip the prity soal had boon lgnored in a oomorhat bighhanded Lashion. Highhandodnose being ono of tho chlol accusations against him, it is not surprioing to find that his oucceseors in offico wore vory caroful to aroid it, with tho reoult that direct marranto bocamo the raro excoption. Novortheieso, thoy wero too obviougly usoful'in arolding long dolaye, ana tho caution ingpirod by tho cardinal'o lall could not 188t for ever. Evagiong of tho prify seal rero again bocomins woro Irequent when Crompell's appointwent as oocrotary lod to a rapid revital of Tolooy's practico. In Fobruary 1535, direct narrante for the firot time agein outnumbered privy ooalo. 3 In 1536, however, partly no doubt as a reault of tho loglolation of the previous year; and partly becauso as lord prify seal Crowmoll would treat the privy seal with less contempt, there Tas a temporary return to a woro otrict observanco of tho rogulations. But this did not last, and during tho romainder

1. Ibid. 774 and 775.

2. A fer examples will ohor thio: January $1541-58,0$ (1b1d. 776 ); Jarch - 472 (ibid. 778); July - 41,6 (ibid; 784); liovembor $-39,1$ ibid. 788); January 1542-34,0 (ibid. 790). 3. Ibid. 693 : 12 privy ooalo and 15 potitions. 
of hio rule Cromell allorod the prity boal to bo oradod moro and more. It became over more uouel for Branto, particularly of monastic landa, to be mado on a petition algnod by tho appropriate authoritios and approved by tho king'o olgnature. noither the oignet nor the privy ooal fore thon collod upon to wake out warrants.

However, Cromell's fall creatod a situation oomowhat aimliar to that of October 1529, oxcopt that busineos atanding over from before his arrest delayod the full offecto for ooveral months. But in the end mattoro dereloped ao one rould expect them to: no one wao nor prepared to ignore the regulations in so soreroign a fashion, and consequently tho c1vil gervice reasserted itsolf. The prity oeal offico managed to ensure that mattors again paosed through its hande in the ordinary way, just as the signet offico had re-ostablighod the ayotem once Cromell had gono. There ras, howovor, a difforence between the routine before and after cromoll. From 1540 onvards, the proper course of waking a grant was nearly almays observed with groat care; the prity oeal files are full of gignet varranta, and tho chancery 11100 full of warranto under the privy seal. To see again that Cromell had organised the oyatom and had given it linal shape, even though he himself had not enforced it. Norked out under him, it bocame manifest 
on hio 1a11.1

Harrents to tho exchoquor and the duchy of Lancaotor ylold 11ttlo of intoroat. Tho formor comprioo tro difforont Eroupo. 2 Tho largo majority aro chancory wita of liberate and allocato, peually on patento and obtainod by tho rocipiont of the monoy as a mattor of courso. Loso rogular paymontn, or auch as moro not basod on somo writton grant, Fero authoriood by privy soal. Among the privy sealo for 25 Henry VIII vio find ordoro for the payment of shoriflo' rowards, of the king'o offoringo, of tho woneg due to the colferor of the hougohold for the $3 t .000$ ge' 8 feast of the Garter, and of revardo to housohold offlcoro from gooda confiscated by cuatowero and othor oxchoquor officialo. 3 Thio divioion botroin chancory and privy sonl rerranta holdo good boforo, during, and after Cromoll'a supromacy, end it 18 cloer that ho did not touch the routine of the privy ooal office in this roopect. Day-to-day oxpendituro of tho governwent was not corored by the exchoquer, so that thero rao no

1. Theso facto supply enother reason why Cromell rocaot tho proamblo of his otatute of 1535. It pas this practico of ignoring tho ordinery chonnols ond cutting out tho rork dono by both the olgnet and privy oeal ofllcos which endangorod the livelihood of. tho clerks. It io likoly that tho proviolon which proved of the groatost immodiate importanco ras the one onduring that 1008 roro paid at all stages oven for direct marrants.

2. Ferrants for iogues for the yo8ro 21-31 Honry VIII (1529-40) aro in P.R.0. E 404/97-103.

3. P.R.0. E 404/99, Iile 1, noo.89;70;73;68,71,72,76,77, and wany others. 
Inducoment to opeed up the procoso of 108400 from 1t. As for the duchy, it has alroady boon notod that undor Cromoll 1 to warranto tended to bo from the central officoo rathor than by order of 1 to orm council, and it hao boon ouggeoted that cromwell was here trying to exercioe an indirect control oror a department where he had no directly controlling porero. ${ }^{1}$ on the whole, it is noticeablo in these 11108 , too, that during bis rulo there ras no strict adherance to the act of 1535 , and prity seals are found freoly mixed with algned billo. 2 after Cromell's fall privy seals rastly prodominatod, as they did in the chancery and no doubt for the same reason. Hore, too, the organiaation which Cromrell had prepared by means of a otatute came to . Iull flororing only after his death had remorod the man who res ready to ignore the rules oren though he had perfected them hiraself.

One aspect, then, of Cromeli's connection with the privy oesl ras thig: he tried to organise its outgoing business and to pake sure that it alrays took its place in the chain rhich ran dorn to the groat seal. In practice, horrovor, he was ready enough to seo these rules oradod by the use of oigned potitions as direct rarranto, whilo waking sure that the clerko were paid oven when no work was done. In a way, Cromell's

1. Above, pp.3101.

2. Tarrants to tho duchy aro in P.R.O. DL 12/6-8,11-12. They are not arranged chronologically, and these bundles corer nearly tho phole of the reign of Honry VIII. 
theory is moro intereoting than hio practico. Ao in othor aopocts of his rork, the former wao organieation, a oafe and officient oyotem; the lattor vao a oowerhat highhanded oraolon of that very organiastion, for the oake of lmmodiate adrantages in opeed and peroonal aocendancy.

So far wo have discusoed the prity oeal as a distributing centre for the orders of the gorornment. As the act of 1535 put It, it 18sued varranto "to the Lorde Chauncollour of Eng10nd, Lorde Kepar of the Great Soale Chauncollour of the Duchye of Lancaotre Chauncellour of the Kynges Landos of Ireland Threasourer and Chamberleyng of the Bschequyer and Chamberleyno of any his Counties Palantynes or Prymcypalite of Fales". 1 Wo now was $t_{A}$ concorn ourgelves with it as a roceiving centro for orders Irom various other departmento. Tho act mentions writings rocolved under the olgnature of the king, the master of the varde, the general eurfeyoro, or other officers. The true extent of the function of the prify ooal is apparent from the files of warrente addressed to 1t. For 21 Henry VIII (1529-30) these warrante survive: ${ }^{2}$ fifty-live signet lettoro, one signed bill, one signed petition, all theso beins rarrante from the kirs; geven varrante on bohalf of the council; tro from the general surveyors; three from the master of the rards; four from the deputy at Calais; one from the chlof baron of the exchequer;

1. Stgt.Realm, 111. 543 . 2. P.R.O. PSO 2/4, Iilo 3 . 
throe from the ourroyoro of forfol turoo and caoual rovonues; tro Irom the cofforer of tho housohold. The council, gonoral ourvoyore, master of the wardo, and ourroyora of forfolturoa orderod prity gealo for appoaranceo boforo thomoolvoo; tho doputy at Calsio askod for the lonue of "protectiono", tho chlol baron for an attachront, the cofferer for ordera to ohorifle to pay his the aodgnments due to the housohold by acto of parliament. 1 liotes of olmilar orders to the prify cool can bo found among the stato papore. ${ }^{2}$

All the departments of stato which had no sosl of thols own wont to the privy soal to got their orders authonticatod. If the treasurer of the chamber rishod to rocover a debt, he wight get the surroyors of the king's casual revenues to sign a fiat to the priry oeal oumoning the dobtor to appoar bolore the trossurer. 3 On the other hand, he himself might write to the lord privy seal, ooking hio lordkbip "to dirocto the Kingoo lottres vnder his prifie seale to Charles Iakeson to content and pay vnto my handes to the Kinges voo tho sowo of xax li' due to his grace at dales explrod by obligacion, or ellos that be appere befor me Imsodialtly tppon the eight horof vppon payne of C 11"", thus oetting out the terms of the roquested privy geal in hio lotter.t In 1533 Cromroll himsolt asked for a

1. 1 Eenry VIII c.16, amondod by $14 \& 15$ Honry VIII c.19.

2. I.P. Add.716,854,1179 (gon.our.); 644,875 (mardo); 876 (roodo) 3. P.R.0. PSO 2/4, 1110 3, noo.107A, 110,117.

4. P.R.0. SP 1/239, L.73 (L.P. Add.945; cf. aloo ibid.932). 
privy oesl to "Iohn Iyngon tho Eldor, Squir, to Appor poroonally octabia Trinitatio" beforo himoolf, and addod undor hlo algnature an autograph request "that thoo pryog soaloo way bo haddo with opodo". ${ }^{1}$ Loro ourprioing io a noto ol gnod by him and bolonging to about tho widilo of 1534: "2ld to havo a prypo ooalo dyrocted to Iohn lyngen tho Eldor, Squir, to Apporo bolor Laotor secretarie, returnabull Craotino Anirarum; Ukkyng moncion that At his laot Apparano ho obotinatly departed at thout lycono."2 The caso io, at best, one of lerr, and as anothor letter shoro, 3 cromell was acting on bohalf of somoono oloo. But ovon oo it proves that the privy ooal was the normal meane to omplgy for a surmons, even for a man who as the king's principal socretary controlled another of the king'o soalo. Thio was particularly the case in the court of requesto rhich did all ito buaineso under the privy oeal, the issue of ordero boing authorlood by eigned endorsemente on various documonto in the particular caso. Tho prity soals demanded by the court vere so eroquent, and tho connection of court and soal so strong, that tho sonior clork of the privy seal rao appointed clork of the court of requosts. 4

1. P.R. O. SP 1/238, 1.107 (L.P. Add.855).

2. Ibid. $230,1.75$ (ibid. 947 ).

3. L.P. vi.607, sir howas Englolield to Cromoll, thankine hin for having a privy geal sent on bis bohalf to John Lyngen. Tho handrriting of the tro notes of Cromell's is quito unlike that of any other document knorm to have come from hlo office; perhapg Englefleld had the notes propared and gave them to Croratell to aign.

4. Lambard, Archeion, p.230. 
Tho privy sealn isauod from tho court, and thorofore probably othor privy :joala iosuod for simllar purpozos by tho ordoro of othor dopartmontu, 1 woro "Infor al lottero" rathor than urito of privy soal.2 Like cignot iettors thoy are honrod "by tho sing", aro coliressod on the outsido, anr bejin at th tho phrroo "inurty corr :olibolovod, 10 groot you :011". Tho dating clauno is poculiar in amiting tho rognal yoar.

Thus tho privy soci har n largo aphore os activity quito unconnoctod rith the passago of grants undor the grost ooal. The warrants indicato that ouch ordoro from obhor dopartmonto continued to cowe in certainly un to 1533. As $1: 0$ havo alroady goen, there are vory lor surviving warranto for tho time of Cromell's supremacy, and thoy are signed potitions. Novortholess it is clear that tho othor sido of tho privy soal'a dutiea did not disappoar ontiroly; a flat fro:n tho gonoral eurvoyoro surviveo for 1536.3 Tho ocantinose of tho watorial in tho privy soal recordo maises it difficult to arguo anything about tho lator $1530^{\prime} \mathrm{s}$, but what io vory otriking is that whon tho fileo of rarranto again bocomo very full and posolbly complote, in Juno 1540, thoy contain nothing but varrants undor

1. Fone have boen found. In the naturo os thingo thoy rould norwally bo lost. Thooo ourviving among tho rocords of tho court of requeoto are almost all orders to magiotrates to render cortificatog; thoso rauld be roturnod rith tho ansFor, rhilo ordero for eppoarames wore not roturnod and aro not thoreforo to bo found in tho central archivos.

2. Cl. Tout, Chaptorg, V.115.

3. L.P. Add.1179. 
tho oignot ordering tho 10suo of furthor parranto. 8uch unaniaity, sopt up for month aftor month, hardiy looka liko an accident of ourvival. The consoquenco of cromoll'o work ooowo to havo boon tho disappoaranco of all thoso ordorg from other officers of otate which gave to the privy ooal 1 to poculiar function of a bureaucratic centro, a clearing-hougo of incoraing and outgoing dopartmental businoso.

There rero reasono why ouch a chango should bogin to ohor in 1540. The mastor of rards and tho zonoral ourvoyord acquired thoir orn courto in 1540 and 1542, and 7 th thom ooalo of thoir orn which made roliance on the privy seal unnooosoary. Tho socond court srallored up ouch other usere of tho prity geal as the troasurer of the chamber and tho ourvoyoro of for Leitures and casual revonues. On tho othor hand, thoos courto Fore later than tho disappoaranco of dopartmontal rarranto from tho prity oeal lilea, and the council did not acquiro its orm geal until $1555 .^{1}$ It did not coase to omploy tho prify oosl until it had a soal of ito orm. Tho rocords of tho privy cauncil shor that ounwonsed to appoar beloro it roro otill mado by privy aoal, though tho practico had ita oxcoptions. Tho boot part of its businose was done by lotters olgnod by the privy councillors prosont, and in tho firat yoar for which rocords survive (Auguat 1540 - August 1541) only fourtoon privy

1. A.I.Dasent, A.P.C. 1554-6, D.130. 
ooalo aro notod.' On tho othor hand, there aro olovon oummonsos by some othor moeno, usually an ordinary councll lottor. ${ }^{2}$ The prity ooal was notor used to autbenticato any othor acts tho council. There was, therofore, oome uso of the privy ooal, but it amounted to rery 11ttlo. Evon no, 1t is ourprioing to find no varrants from the council preserved at all. Posnibly ordero for privy ooale pore given by rord of mouth, but thet 10 not a convincing explanation. The privy ooal offico rould not be likely to act rithout sowe permanont rarrant with which to protect itself in caso of trouble, and tho council had certainly in earlier yoars been in tho habit of looulng writton piato. One can only conclude that ouch for warrants as woro rocoived rere liled oeparately from olgnet billo and aro lost. The game Fould hold for ordera from other officialo who mut, wo aro compolled to think, havo continued to use the prity oeal before they had soals of their orn. The careful preoervation of aignot rarrante, filod wonthly and ondorsod by the clerk on duty, makes one suspect that there $7 a$ a purpose bohind auch discrimination. Lay it not havo boen that the dual rôle of tho privy soal 7as boing rocognisod, that its rork as a link in tho chain of varranty ras boing oeparated from ito indopendent rork? With tho lattor alroady wuch roducod in amount and conotantly decreasing, the wain rork of the offico, and thorolore

1. IIIC0188, A,P.C., Vi1. 5,59(3),84(4),120(2),123,186,187. 2. Ibid., pp.10,24,82(3),84,98,103(3),192. 
tho wain concern of ito organioation, mot havo boon fith tho formor. Thereforo, olgnot warranto woro trontod with caro and attontion, whilo departiontal rarranto, gotting foror all tho tiwo, apporr to havo bocome thingo of 11 ttlo conooquenco. Although the prify seal continued for a time to recolvo rarranta of various kindo, tho cenoral devolopmont, ind catod and holpod by the nor courto with thoir soalo, was torardo raking it no more than a stage in the chain from potition to grant under tho great soal.

It wight bo argued that this derelopmont mot havo beon coming for a long tire, but there 1o enough oridence to suggest that it goos back no rurther than cromell. In 1533 thoro were miocellaneoue warrante in the 11lee; by 1540 thoy had dieappoared. It was notieaablo that Cromell's act of 1535 ignored the privy seal excopt as a varrant to other ooals. Thet may not havo been a sign of express purpose but it shorrod bis attitude. Hio personal gorernment in all branchos of the adminfotration undermined the inportance of the privy 800 to individual officials. A study of bis corrospondence ohorid that be could do by personal lettors a good deal that normally rould have requirod a prify oeal. Taking only one year, 1537, 7e find him requeoted by tho treasuror of the chamber to help in the recorery of debte, 1 ordering an eppearanco belore ningolf

1. L.P. X11.II.1048. 
and the council, ${ }^{1}$ and ordering an arrost and a rolo000.2 70 hero albo goon that a lottor of his could bo troatod ao though it wore a prify ooal omanatine from the court of roquooto. 3 The lord prity soal's lottors took array much of tho buatnoso of the prity $00 a 1$ 1toolf, and 1 it 18 for this roason that wo find practically no rarrants oxcopt algnod potitlons for tho timo of Cromell's supromaey. To cannot clafe that no rarranto of other kinde rero recoirod at all, but in vior of tho wany surviving bofore and the full stato of tho rocordo after his time, wo cannot roally ascribe the paucity of recordo botroen 1534 and 1540 to accidental causoo. Tho now courto, too, with thoir individual sealo, roro a Cromsollian dovolopment. He hed founded the firot of ther (that of tho augrontationo), and had planned the court of rards, and thoir indepondont otatus and independent ooals must therefore havo boon in egreoment 71 th his 1de8s.

It is clear from all this that cromoll intended to rostrict the privy soal to ito wost routino duties, and that ho vory noarly achieved his aim. That littlo extra basiness rewained to the seal disappoarod as Cromell's ldoas continued to bear fruit under his succossors. Tho oamo principle lo horo soon

1. Ibid. App.41. As early as 1534, ono of his corroopondento olfered to lotch a man duo to appoar bolore the council nithout the formality of a prify seal (L,P. Vii.692).

2. Werrimen, 11.62 (lottor 191).

3. Abore, p.148. 
at rork ao that rhich organlood and dopartwontaliood tho troaouror of the chambor. Cromroll apparontly did not $11 k 0$ organisations rith a rido and rathor indofinito ocopo. Ho Flohod tho prify ooal to bo unod bn ono particular ray lald dorn by obatuto. Ilo $\nabla 1$ shod, 70 may ouspoct, to 71 thdrar from it thooo adminiotrativo ordoro which ho proforrod ohould go through his private offico organiantion. Tho ovidonco is, porhaps, not full onough to allor of too dofinito conclusiono, and thore io alrayo tho poodibility that tho privy ooal carriod on wuch as before but lolt no traco of ouch ectivity. Horforor, all that has been agld indicatoo hor unlikoly thet pooalbility 13. On the whole it 800 s that ro may otand by our conclusions: It 780 Cromell's policy to circumecribo the functione of tho privy oeal. As a conoonuence of his adminiotration tho privy soal was soon roducod to a puroly lormal part in tho proceos of loguing grants undor tho groat seal. For a timo it continued to bo omplojed by othor agencios - tho council and, in perticular, tho conciliar courto. Fhon that use had gone, and it had gono entirely by 1642, tho privy ooal had bocome superfluous. Its gurvival into tho ninotoonth contury ras a triumph of rootod intorooto oror adminiotrativo officioncy and concon sence. 
III. Cromoli'B Poroonal Activity.

The improsolion bao posolbly nor boon givon that tho olgnot and privy soal vero virtually dormant during Crorwoll'n adminiotration, and that ho did without the ooalo and offeco of which ho wao hoad. Thio rould bo quito wrong. Crorsell pald careful attention to tho organisation of the tro ooalo in their formal aspecta, and though he thon proceodod largely to orade nis orn organisation and rogulationo that doos not mean that the two soals and their otalfs poro not employed to a certain extent in thoir routine dutioo. Tho privy oeal in particular continued to send ito varranto to the chancery and other dopartwents, aido by oldo if th tho olenod potitiono by wane of rhich it ras eradod. Lioroover, the algnot ras in Iroquent uoe for the sorling of tho king's corronpondenco, not to wention Farrante for expondituro, and olgnot clorko rore kept busy in writing theso and other nattero; and ovon though the privy oeal's independont activity nao oovoroly curtailed it wao not extinguished. The offices did thoir rork, and wo wast now turn to the part played in that nork by Cromell hin8011.

The draft of the act of 27 Henry VIII c.11 (for tho clorks of tho oignot and privy soal) deocribod in dotall tho way in rhich a grant was to be wade. It loft no doubt that the secretary and lord privy oeal mere to be poroonally active. Tho 
kingo of England, it tiao doclared, had novor wacio a grant un1088 it had firet boon oxaminod "by thair principall socrataryes as porsonages mood noro of thoir moot honorablo counoaill, and which by dayly and contynuall vior and aight ought bost to knorio tho true caractos and signos of thoir moost noble handes". After the socretary's oxamination tho bill ras to be "lelt in the Custodye of ono of tho clerkeo of thoir signot", who vould direct his rarrant to tho lord privy ooal. "And 11keriso the saydo bill of rarrounty beyng oxamyned by the sayd lordo kepar of their pryvey Soalon, a further varront rould iseue. ${ }^{1}$ This procmble pretended to bo a rovier of past practice, and the rost of the draft wes to enforco tho practico in the present. It 700 , therolore, Cromsicll's intention that tho eocretary and lord prify soal should attond to thoir dopartmontal dutieo. This in itoolf offers a foirly strong prosumption thet Crowell hirsolf did so attend whon he hold the officos. Haturally, ro are not in a position to tell rihethor bills reachine the offlcos rere alrays ocrutinioed by tho oocrotary and lord privy soal; no ovidance survivos, or could survito. It can, howover, bo ohorn that outgoigg documento riore often examined by the departmental heada. Gardiner had initiated a practice of regularly countersienine rarrante undor the olgnot.

1.P.R.0: SP 1/101; 11.2928-3.

2. At any rate, his is the Iirst oocrotery'o countorolgnaturo to appoar amons tho rarrants for tho privy soal (P.M.O. PSO $2 / 4$, filos for 22 and 23 Honry. VIII) and the groat seal (P.R.O C $82 / 669 / 5,679 / 4)$. 
Ho did not oign thom 011,1 but ho mado tho chock oo uoual that oten whon ho rao array on embaogy oomo counclilor rould bo doputod to carry out that duty. Thus on 22 warch 1532 tho almonor, Edrard Foxo, Eignod a rarrant "In aboontia Rouorond domint socrotarij".2 At tho boginning of hio socrotaryohip Cromoll continuod tho practico, and noarly all tho for of gnot warrants that ourvivo for his tonuro of offico besr hio oldneture. 3 Hore than this: ho oooms to havo mado it part of the secrotary's duties to countorsign prify goalo rich concornod his dopartportal ophoro, tho aignot offico. In July 1534 ho oigned a privy ooal for tho grant of an annuity to John Codarive, clork of tho sicnot.4 Thoro aro no warranto extant aftor August 1535 so that ro cannot toll rhat happonod Fhon Crompell becamo lord privy seal. Il continued to hold the oocrotaryohip, but one rould on tho whole suopoct that as his dutios became evor noro nurerous and as ho camo to opond his time more and moro on mattore of bigh dowestic and forolgn policy ho could no longer lind tho tiwe to attond to ouch dotailo as the signing of ferranto undor tho oignot. Thio

1. E.g., P.R.0. C $82 / 629 / 6,666 / 13$. Tho lottor of thoso 780 gigned by the king, which way havo mado tho socrotary's ofgnature superiluous.

2. Ibia. $653 / 18$.

3. Ibid. $674 / 4$ (this, as is poncillod on the documont, belongo to 1534, not 1533 as tho dato protendo) $681 / 26-7,688 / 5$, $700 / 28,701 / 1$. Tho excoption io ibid. $700 / 14$ mich io not countersigned by Cromoll.

4. Ibid. $685 / 83$. 
ooowo the moro likoly in vion of the eradunl comine to tho foro of Thomas Friothosley, whose caroor 10 invootigatod bolon. 1 Another intorooting fact which rhorio Cromoll'n poroonal ouporvioion of the afgnot offico is that the varrant anpolnting a oignot clork rould be addrosood to him by narse and titlo.2

Closely connocted with hio oignet dutios rao the socrotary's task of obtaining the royal signaturo on lottoro, billo, warrante, and granto. Durine tho oarlior yoaro of his adelnistration Cromell carried this out himolf. An agont of Lord Lislo's reported in 1535 that he had givon a bill to Cromell to be put among the other billo which roro next to be oignod.3 Henry ras apparently in the habit of olgning batcheo of docusents at intorrals, rather than attonding to ororything as it came in. On another occasion lisle ras informod that a bill of his should be oigned "when the king doth next eign".4 To have it on the authority of Ralph Badlor, much of whoso timo ras spent in trying to got papors oigned by the king, that Eenry disliked this office work oo much that ho frould oron defor reading through the instructions for an ambassador boceuse ho did not lool like oigning thom. At ouch tinos his secretaries and oerranto kner that it rould be hard to get anything signed. 5 a consequence of this was that many routine

1. Section IV of thio chapter.

2. L.P. Iir.II. $435(2)$.

$4 i$ L.P. xil.I.492.

3. L.P. Vi1i.531.

5. L.P. $x .76$. 
lettoro or rarranto woro ol gnod with a otamp and novor approachod tho royal prosonco. In tho lottor fust quotod sadior mado a diotinction botwoon lottoro otampod, rhich ho rao for warding to Cromoll, and lottero to bo olgnod, thlch ho could not got attended to, and docusonto boaring a otampod inotoad of a rritton of gnature can bo found otrom all oror tho volumeo of otato paporo for tho roign.

Tho way in which Cromoll poroonally handlod tho king'o corrospondonco is apparont from his momoranda. A liot of moosengero mith tho lottoro thoy roro to carry rould bo dram up, and tho lettoro rould bo both Cromoll'o and tho king'o. 1 A oimilar liat rould bo hoaded "rarranto, lottoro, and billo esoignod", to be follorod by "lottars olgnod with tho - ", Fhere tho blank should probably bo filled in with tho rord "stamp".2 These aro notes of buolnoes dono; ro can aloo produco a roady exapplo of a papor which Crowell himeols dron up before going to tho king. It containo notog of lotters and warranto to be olgnod, of an autograph lottor to bo rritton to tho king of France, and of a for othor pointe of business which rero not connoctod with tachnicel oocrotarial dutiog. 3 Thero io thon no doubt that cromoll carriod out thege duties, the dutios of having tho king's lottero fritten, olgnod, sealed, and despatched. Tho lact that oo many of tho
1. L.P. ix.229.
2. Ibid. 232 .
3. Ibid. 836 . 
kefs'o lottoro toro draftod and riftion out falr by clorko of tho olgnot, espocially Frlothooloy and Dorby, ohowo that ho omployod tho olgnot offlco for tho purporo.

He did not almayo, of courso, obtain tho king'o olgnaturo in person. Sadlor, wo havo ooon, cent him lottoro etampod and promiood lottoro oigned. On anothor occasion sir Thomas Hennago informod Cromtoll that ho had obtainod tho king'o ofg neture on "your throo billo". 1 a groom and a gontloman of tho prify chamber, thooo rould noturally bo omployod in tasko rocuiring proximity to tho royal poroon. Thothor or not Cromell himoll obtalnod tho olgnature rould dopond, ono may ouppose, on whother ho rao with tho king or not. In his oar Ifor yoaro in offico ho was woro caroful to otay noar tho king; lator be would often remain in London fhen tho king ront on progrese. 2 One rould hare thought, then, that at least ho rould bo caroful to keop tho olgnot in his orn hand in ordor to waintain otrict control. But ro haro alroady soon that eren bolore ho was sccrotary and whlle acting ao Gardinor's doputy he rould leare the olgnot in the custody of a oorrant. 3 In that particular caso sadior ras probably novor far from

1. L.P. IIV.II.163. Tho bills roro: a lottor in tho affair of Sir Clemont Toet, a rarrant for ropalro at Hoodstock, and a petition concorning tho discontinuanco of a oorjeantohip-atlaw. Thio mixed bag typiliog tho kind of thing that pasood under tho king's of Enaturo.

2. C1. Cromoll's itinorary in Lerriman, 11.2791..

3. ABOVO, PD.1021. 
Cromell so that tho peroonal control romalnod, but thoro 10 anothor and rathor moro llagrant oxamplo of tho way in rhich tho oupposod principle of porsonol custodianohip of tho ofenot alght bo lloutod. In July 1535 Bonnor nas about to loavo for Germany and rao expecting a lotter for tho duko of llolotoln. cromell told hin that Gostrick, a oorvant of hio, it ia truo, but quite unconnected with the clerical buroaucracy, rould doliver it to him. Gostrick dic so, baving got tho lotter from tho king and sealed it with tho olgnot which Cromell had loft with him for the purpose. Ho wrote to say that he rould sond the seal up by somo substantial moseongor; this turnod out to be Jilliam Johnson, a member of Cromell's private otaff. ${ }^{1}$ such a procoodine can only be described as irregular by all the standards, and it remindo ug again hor porsonal Cromell's rílo reo, and hor little attention ho rould often pay to the approved forms and rules of procodure.

As lord prify soal, too, Cromell attonded to his departpental dutios. There ras no rule or practico cancorning countersignaturea, but it ras comonly assumod that the lord privy seal was actively in charge of hio office. liot only were formal marranto addrossed to him by namo, which noed not prove anything, but informal requests for privy soalo woro also sont to him porsonally. Tuke and Cromrold both rroto notoo to

1. Lerriman, b.412 (lotter 110); L.P. Vii1.1109,1123. 
tho earl of Filtohire, coising him to lisuo prify oools. ${ }^{2}$ Cromrell's act of 1535, f? perti nias tt obrlier draft, had ar sumed porsonci rooponsitilition in the koopor of the privy roal which prove thet departrontal buminors ins ritill nuponod to occupy a goor deal of that of ricer's timo. Tho ovidonco o: nrivj senl barrante indicates that Cromield modo no chango in this. Ilis signaturo anpoars on a for: surviving varranto, though thore is in evory caso somothing unucual sbout tho docunent. The privy 3001 wisht by rititon and oignod by a clerk of the signet (Godsalro), in ihich Cromiroll's countersignoturo :as presumbly intendod to covor and authorioo tho irrogularity.2 Or the clork's naide ras oraso: and Cromoll bignod ofor it: this nrivj soal grantod a pardon to the bishop of Lincoln 30 kooper of the caotlo of Janbury for tho oscapo of felono from that prison, ond it ras somornat largo in 1 to tering cromell's porsonal imprimatur may have coomod dosirablo.3 Ho signod tho parrant for the reotitution of Bonner's tomporalitiog on his election to the soo of Hereford; we way suopoct that this ras tho signature of the vicogorent in epirituals rathor tho the lord privy ooal'o.4 His oignaturo on a privy 0001 to the colloctoro of tho r.ool customs in London on bohalf of tho marchants of the Btaplo ought porhape to bo tracod back to the

1. L.P. Add. $355,932,945,947$.

2. P.I.0.C 82/743/2.

3. Ibia. $748 / 10$.

4. Ib1d. $749 / 55$. 
intoroot bo alwayo ohoriod in commorcial mattoro. 1 Horo dollnito proof of his diroct and poroonal control of tho privy ooal offico can bo found in tro tiarranto dispatchod roopoctivoly Irom Thruston (Hampohiro) and Donnington Cantlo (Borkohire) in Auguat 1539. Cromsell was apnarontly travoling with tho court at the time, 2 and rhile the privy soal offico mao, of courge, lized at Nootminstor, ${ }^{3}$ tho noal soomo to havo boon with 1 to kooper on that occasion. The rarrants roro olgned, not by a clerk of the privy seal, but by Thomas Soulomont, Cromoll's porsonal socretary, 4 "in absontia," as ho wao caroful to add, "clericorum priuati sigilli do mandeto domini priuati sigilli."5 The ovidenco may be ocanty but it 10 concludive. Throughout his caroor as socrotary and lord prify soal Cromoll attondod to his dopartsental duties. Horrover, it was quito out of tho question that rith oo bany traks arraiting hit ho ohould havo done all the departmental rork of ouporvioine tho signet and privy seal officed, and he thorefore choso a man to bo virtually his depty as head of the clerical organioation. That man ras Thoras Vriothosley.

1. P.R.O. E 159/318, Commila, Easter torm, Recorda, m.13. 2. Ho dated a lottor froa Donnington Castlo on 16 August 1539 (L.P. xiv.II.83).

3. It had boen so oror sinco about 1360 (Tout, Ghaptorn, $\nabla$. 721.).

4. D.II.B., xviii.679b.

5. P.H.0.' C 82/757/9,13. Thio last privy seal gas based bn a olgnet marmant (Soulenont added: "Tavorner oxpedit lit toras signetj"), a Lact rhich ohould again make us caroful not to assume too complote a cossation of tinat ooal's routine dutias. 
IV. Themas Friothooley, Crompoll's "Undornecretary".

Wriothooley wao apparently in Cromroll's gorvico as oarly as Fobruary 1524 whon he was not jot ninotoon and just down from Cambridge. ${ }^{1}$ Cortainly, documonts in hio handrriting provo him to havo boon a clerk in Holooy's housohold from about that time onwardo. There are roforences to him in 1529 ao gervant to the cofforer of the household and as mesoengor for the king, ${ }^{2}$ but nothing furthor can bo found about him in thoso capacitios. By lay 1530 ho was a clerk of the oignot, 3 and it was there thet his official caroer bogan. Ho nor, of couroo, came under the socrotary, Fardiner, and may have boen bio servant in the tochnical sense. Ho cortainly actod ao mesgenger for him.4 llevertholooo it rould soom that he did not lo8e Cromell's Lavour. In January 1531 he rocoived tho grant of an annuity of 25 from the abboy of St Mary, York, 5 grant which was in the gift of the archbiohop of York or rathor, York being vacant, in tho king's. Tho adminlotration of racant gees was at the time in Cromroll's hands, ${ }^{6}$ and it ooems reasonable to suppose that Mriothosley orred this annuity to him. There are a fer drafto of Cromoll's lottoro in iriotheoley's hand for this period. Ono of then concorno official businoso, tho election of an abbot, and rould perhape provo nothing for

1. D. H. B., Ixi.10638.

3. Ib1d. $6600(11)$.

E. Ibid. $80(25)$.
2. L.P. iv.5979,6489.

8. L.P. $\nabla .723$.

6. ABOVO, p.185. 
the relationohip of tho tro won, 1 but tho othoro aro privato lottoro Irom Cromoll to Molooy and could not havo boon draftod by Wriothooley in bio official capacity as clork of tho olenot. 2 In the latter half of 1533 Friothooloy wao Cromold'o go-botwoon with the abbot of Hydo. 3 Altogother it $800 \mathrm{mo}$ 11koly that ho continued hio association ofth Cromsoll's oocratarlat dosplto hio clorkship of tho olgnot and official sorvico undor Gardiner, though theso factors will havo limitod tho timo ho could spend in Cromeli'o service. In any caso ho ras aboont on ombassies for a good part of 1533,4 though ho was back at tho gignot office by Fobraary 1534.5 Tro moththo lator Cromroll took over the secretaryohip, and from then onmardo Nrlothooley remainod fully employod in his sorvice. His handwriting appears in the king'o lettors as woll 08 Cromsell'o, on the backs of petitfons signed by the king, on tho faco of signot warranto, and on many another documont.

He is doscribed as clerk of the olgnet unt1l at loaot tho middle of 1537.6 In June that year he ondorood hio last ourviving oigned petition sont to tho privy goal, 7 though thoro Io a general ourveyora' bill of April 1538 olwilarly ondorsod by him. 8 He was thereforo cortainly working in tho oignet

1. L.P. $\nabla .1340$.

3. 底.

2. L.P. IV.6368,6571. by Triothesley.

6. L.P. xil.II.109, 131, App. 30 .

7. P:R.0. PSO 2/4, file for 25-29 Honry VIII, no.30 (18 Juno).

8. P.R.0. C $82 / 736 / 33$. 
office until that time. Ho did nbt, in lact, ourronder hio clerkship until he becamo socrotary, for Thowas knight rao appointed to succeod him as clerk of the oignot on 14 April 1540. 1 Novertheleso, it seems that his pooition at the oignet office did not remain the oame all the timo. Fe have seen that in 1534 he was simply one of the four clerke of tho gignet who took his turn with the others. ${ }^{2}$ In september 1536 it was remarised that ho was in Cromoll's opocial lavour and was a good man to approach if Cromrell nedded persuading. 3 In 1537 it was noted that he had acquired a new importance, and Lord Ligle's agent reported him to be in a position where ho could do mach for suitors to Cromell, whore indoed he could "please end displease".4 The impression is thet from being merely a favourite leading servant he had groduated into a position of some independence. By 1537 ho ras correcting, and therefore suportioing, documento dram up by other clorko of the signet as though he held a superior position vithin the office. 5 Taking this together with the fact that ho ras deocribed in June 1537 as "principal clerk of tho signot under my lord privy soal" by Sir Robert Finglield of Calaio, himoelf a courtier and official, 6 and that tho ovidence for his having

1. L.P. $20.611(17)$ 2. Abovo, p.284.

3. L.P. Xi.460. SP 60/4 4. L.P. Xii.I.492; II.555.

5. E.g., P.R.0. SP 60/4, Pf.98-101 (L.P. xi1.II..378[2,3j). These instructions rere cortainly tho rork of the sionot offico, and Mriothesley's correctiono wero rany and matorial. 6. L.P. Xii.II.163. 
attended to the routine of tho oignot offico givoo out about the time, wo fool justified in suggosting that by tho middio of 1537 he had censod to bo an ordinary clork of tho $31 \mathrm{gnot}$ and had acquired some proeminonce among his colloasuoo.

Friothosloy's signature does not appoar only on aignot marranto, for ho also signod privy soals. Tho first examplo extant belongs to early Soptomber 1536,1 and aftor that dato bis name is found at least as often as that of any othor clork until he aigned his last privy oeal on 30 Warch 15t0, probably a day or tro before he took ovor the secretaryship. ${ }^{2}$ yot ro can be quite certain that he ohip of the prify seal, for the cherko were onumerated in a grant of April 1537 where their names are givon as Richard Turner, Robert Forthe, Thomas Jolferey, and John Hover. 3 Though four was the normal number of clerks more aight bo appointed, 4 and other men are known from the of gnetures on privy seals to have rorked in the office. Jefferey, for instance, employed an undercierk, Reynoldes, who signed in hio mastor'n Irequent absence. Undoubtedly thore wore several euch underclerks. But it io certain that a grant of the rovoroion of a clerkship which gives tho presont holders rould liot all peroons properly appointed to the office, so that it way bo

1. P.R.O. C $82 / 716 / 3$.

2. Ibid. $764 / 77$.

3. L. . . xii.I.1103(15).

4. Lasmell Lyte, Groet SeRl, pp.3211. 
taken 8.8 proven that Friothenloy soal nome nix months aftor ho startod oigning privy noalo. On tho othor hand, it is hardly orodiblo that ho ohould havo beon omployed thoro 00 an undorclork. lo undorclork gigned 00 many varranto, that 10, 78080 cloarly on a lovol rith tho full clorko. Nor can ro imagino tho lord privy segl's confidontial privato clork taking ouch an inforior position in the privy ood office. Woroover, Friothooley ras a full clerk of tho signot, and by tho ond of tho contury it wao certainly true that such a clorkohip carried with it a highor social standing than that of tho privy ooal. 1 To canngt be sure whothor that was 80 in Cromwoll's timo, for in the fifteonth century tho pooitiono appoar to have boen roversod, 2 but oron if clerks of tho signot rero etill conoldorad inferior to those of tho privy $80 n 1$ mo may tako it that thoy pore much higher in the social and offiolal ocale than underclorks of the privy seal. Triothosloy ras not a clork, and could not havo boon an underclerk, of tho privy ooal, and yot ho did as much rork in that offico as any of tho full clorks there employed. Havo ro horo oimply anothor example of a typically Cromellian irregularity? Clorks of tho signot rould occasionally sign a privy soal, porhaps bocause the

1. H.H.C., Hetfield ISS, vii.419. Gell to Cocil, to the offect that the clerkohip of the signot nas "more esteomed and nore veluablen than that of the privy soal.

2. J. Otway Rutheen, King's Socretary, p.135. 
propor clerks roro not arajlable at tho t1mo, but it rao rory rarely done. ${ }^{1}$ If Nriothooloy's work ras no woro than an oxtonolon of that practico, it ras an irrogularity on oo largo a ocale that the explanation socmo thoroughly unnatiofactory. Tho anstror, Fe auggoot, 10 to bo found in a rodioval paraltol. From 1to oarly boginnings tho otalf of tho privy geal offico had usually included a man tho was not a clork of the privy soal, and apparontly had no hopo of orer bocoming ono. That was tho koopor's poroonal clork, "an important poroon in a modest ray", who vould bo omployed to risto for tho privy oeal in tho koopor's absonco.2 Esoontlally that doscription Iits Hriothesley. Ilo fao Cromoll'o poroonal clork and servant, and ho ras omployod at the privy ooal offico only aftor cromoll had taicon over tho kooporohip. Hio rork in this office, unlike his rork for the olgnot, fao cloarly tho rooult of his relationohip with Crowoll, and of Cromell'o tonure of the office of lord privy ood. Cromell put him in tho privy ooal office as his porsonal clork, that 18, ho nado hin his peroonal reprodontative thoro. Thore can have beon only one reason for employing hit thas, a doolro for adminietrative control and efficiency. Cromell rantod somoono

1.P.R.O. C 82/662/18 (Nov.1532), Godgelvo "in aboontig JofLerey"; 743/2 (Aus.1538), Godoalvo's oi gnaturo authenticatod by Cromtoli'a countersignature; 765/4 (April 1540), Godsalvo alone.

2. Tout, Chaptera, $\nabla .781$. 
ho could trust to look after the privy ooal offlco for him. Ho could no longer oxorcloo day-to-da: ouporviolon ovor tho clorks, and did not, on tho othor hand, want to lot tho dopertment alip from hio control. If wo do not attach too forwel a moaning to tho torm, Fo may doocribo Nriothooloy 88 the lord privy soal's deputy in tho privy 8001 offico.

There was a third organisation with rich Friothealey had mach to do. To havo sororal timeo doscribod him as CromFoll's confidentiel clork, and that ho was thio lo provod, for instanco, by the many drafto and fair copies of Cromell 0 lottorg which aro in his hand. Ho did this kind of rork alwoot up to tho tinio of Crowoll's fall, though a distinction mould here eppear necesoary. Ho rrote two surviving lottero for Cromell after ho had boon appointed to the principal cecretaryship, but one of them was to his colloaguo, sadlor, and the other to Richard Pate, and both roro concernod rith alfairs of otate and diploracy.1 But ovon in January 1,540 ho res otill drafting somo of Cromell's ordinary correspondenco, 2 and as late as Soptomber 1539 ho wroto a woot unirportant and routine letter of Cromell's asking for onculries in a "poor men's caugo". 3 Ho 78 s thorefore on Cromoll'o poroonal otafl until ho becasse principal sccretary.

i. I.P. $2 \nabla .469,662$.

2. Ibid. 16,35.

3. P:R.0. Req 2/2/203, no.3. 
His position on this otaff io tho 1000 oaoliy dofinod bocause Cromoll's privato offico io a woot obscuro affalr. Quite cloarly it did a vast crount of tho rork roculrod in tho government of England. Cromoll gorornod largoly through hio privato correspondence, and that mao ritton and rocolrod, ondoraod, clasoified, and lllod, by hio privato clorko. Tholr handwritinge aro ofton quito familiar, though bolng clerical hande they too eroquently lack delinite idontifying foatures, but thoir names eocape uo. To be procioe, whero wo know tho nawoo re cannot identify the hands, and famillar hando lack any known owners. The hear of oome of thom: Rlchard Cromell, John Filliamoon, Thomas Soulowont - to liot oomo of tho leading members of his otaff; Henry Polsted, Thomas Thacker, Thomas Arery, William Johnson, Milliam Body - those aro a for of 1080 well knom oner, picked at random. An interesting liot of his housohold of the lete $1530^{\prime}$ s no doubt includos hio office ctaff; It oloo includos wach wore, and it is imposolblo to dioentangle the one erom tho othor.1 To cannot reconotruct tho office with ito organioation, for evorything appoaro ao far too fluid, Fith differont pooplo doing tho saro or different jobs without any distinct diviaion of labour. In thio rague picture of an offico doing lto rork rith conoldorbblo efficioncy and apparont absenco of organisation, wo can dio-

1. I.P. $x i 1 i . I I .1184$. 
tingulah Mriothesloy as a poroon of importanco. Hio namo and bandrriting appoar so ofton that it soomo right to call him a chiel clork there. But it mast be roallood that one han to go by a genoral improsoion rathor than by tho guldanco of cloar and unmistakable oridonco.

To are, horever, in the happy position of posnonolng ono document ribich onablos us to say a littlo wore on thio oubject. It givos us a wowentary glimpoo into tho ray in rhich tho clorical organioation rorked undor Cromwoll, and it aloo throws oome light on Friotheoley's position. Then tho edministration of the northern borders ras reorganiood aftor tho pilgrimage of graco, a document was drawn up appointing the officors of the "mootmarches fforanempot scotland" and listing the won who fiore to ansiat tho doputy rardon. In one copy of thio paper the nomeo are bracketed in Eroups, with nawer vitten againot the brackoto by someono other then the clerk who wrote the document. 1 These nameo aro: Tarornor, Huttoft, Jermyn, A. Roke, Godsalvo, Dorby, and "T.S.". Thoy rore undoubtodly the clorks doputed to frito out tho conmioolons of the gentlemen againot whoso names thoy rere placod, those lotters missivo which a for dayo later tho duko of Norfolk delivered to the commisaionors. 2

1. B.H. Calig.B.ili, 1f.246-7. Calendarod, rathor insufficiently, in L,P. xil.II.249(7).

2. I.P. Xil.II. $\overline{248}$. 
And a mixed lot thoy rore. Godmalvo and Derty noro clerks of the signot, whilo Tavornor and Euttoft both obtainod thio pooition oomo tino lator though thoy did not hold It at the tine whon this documont was drats up, that is obout July 1537. Huttoft was appointed to ouccood Dorby in October 1539,1 and Tarornor'o oignaturo lirot appoaro on olgnot warranto in 1540.2 Food anyo that he ras mado "ono of tho clerka of tho oignet in ordinery" in 1537,3 but as no warranto ourvive for that poriod the statewont cannot be ol thor provod or disprovod. Thero wore, howover, four clorks of tho olgnot in 1537 (Friotheoloy, Derby, Codsalve, and Paget), so that Taverner is moro likely to heve boon an undorclork. In any case it is most probablo that both won rero trained as underclerks before boing promotod to full clerkshipo. Doth had been trained on Crompll'e privete otalf. Tarernor hed boon Crowtell's "client" 89 early as 1533 and had rorked for hiv ever since, mostly as a propegandist of roformed opiniono. 4 Euttoft doccribed Cromell at about this tidio os his lord and waoter, and wroto to Friothooley in torms ohich indicate that the latter may havo been his istediate superior. 5 Tho other three men held no pooition in the official clorical bureaucracy. Jormyn was almost certainly that brothor of Germyn,

1. I.P. IiV.II. $435(2)$.

2. P.M.0. PBO 2/4, Iilo Ior Juno 1540.

3. Tood, Athenes (ed.Bling), 1.420 .

4. D, IJ.B., 2is.3.394.

5. L.P. xi1.II.546. 
oorvant of bishop Rowland Loo, to fhom Cromiroll ohovod farour in 1537.1 Tho farour probnbly consioted of Jarmyn bolng taken into tho lord privy soal's sorvico. Anthony koko frao at ono timo sorvant to Katharino of Aragon, 2 but had ontorod Cromoll'o sorvico by tho lattor half of 1536 whon Gootricls, in tho north elghting tho pilgrimo, wroto urgontly for hio oervices. 3 He cooms to havo boen tranoforred frow Crommoll' otalf to Hriothosloy's by tho boginning of 1538,4 though ho continued to belong to Cromroll'o housohold." "T.8." cannot in the circumstancos havo meant anybody but ihomao Soukomont, apparontly tho king'r Fronch oocrotary in $1536^{6}$. but doscribod as Cromell's socrotary in liarch 1537.7

To have, therefaro, hore an oxamplo of a cortain pleco of rork boing shared out anong tro clorid of tho oignot, tro undorclerks of tho oignot who had at any rato once boon Cromioll'o sorvants and probably otill woro, and throo clorko from Cromroll'a privato otalf. Thio provos ovorything that has already boon said about the indiacriminate uso of tho sionot and tho privato officos, but at prosont ro aro moro intorostod in tho omiosions from the liot. Fhy wore tro clorlso of the oignot includod, while tho othor tro roro not? Tho addition of tro underclerks indicatos that it rao intonded to uso tho full

1. I.?. xiii.I.152.

3. Ibia. 791.

5. L... xiii.II.1181(iii).

7. L.P. xii.I.1096.
2. L.P. xi.1082, $1436(2)$.

4. L.P. xili.I.20,44,151.

6. L.P. Xi.1400. 
otrongth of tho of gnot otafl. Pagot wao normally omployod on ombagaios abroad; ho may havo boon out of tho country at the timo, and in any caoo was probably not availablo.1 But no such roason rould account for the oriogion of iriothesloy. He was not only in England but had aotually draftod somo of tho documento concorning the goternment of tho northorn bordor. ${ }^{2}$ There can be only one reason why he ras not ordered to write out somo of tho commigaiono, as nore Dorby and Godorlvo. Ho must have been in a differont position from thoiro and his otanding mast have beon higher. Hio dutios, ouch as the drafting of the echeme, were those of an underoocretary rathor than of a clerk. Llay de not suppose that it was he who had apportioned the other clerko' taoko? Wo cannot claim with full confidence that he bimelf wrote the nomeo againot tho brackoto; there is not enough of the rriting to be dofinito; but fo posoible. At any rate, tho fact that he ras lelt out whon the other clerks of the signot rere put in further confirms the essential difference of his position.

The document has done one other thing to clarify the offico and standing of Friothosloy. It has provided us vith the names of two wen, Huttoft and Roko, who wero Cromell's oorvants in namo but troatod Nriothooloy as thoir mastor in lact. In Cromrell's offico, too, Briotherley occupiod a

1. D.X.B. , $x 7.60$. 2. L.P. Xi1.II. $249(2,4,5)$. 
opocial pooition. If ho camo botwoon cromoll and hil otalf it moano that ho was in chargo, undor Cromoll, of Cromoli'o privato socrotariat.

Wriotheslog's poaition wao thoroforo thie by tho lattor balf of 1537: he was "principal clork of the oignot", ho rao Cromrell's personal repreoontativo in tho privy 000 of offco, and he was the hoad of Cromiell privato offlce. It ras through these threo secretariats that Cromoll tranolatod his adminitsrative ordera into action. As thoir virtual hoad Vriothooloy occupied a place which it rould not bo incorrect to doocribo as that of Crommoll'o undersocretary, his chol de cablnot. Ho may concludo that Cromoll had appointed him to that position because tho detailed supervision of tho dopartments of the bureaucracy was clearly imposible to 80 buay a man as tho lord privy ooal.

In the light of thio discorery, Mriothooloy's appointwent. as principal secrotary in April 1540 assumes rathor a nor appearance. Ho had, in offect, boen for woll ovor two yoaro tho imediately reoponoible head of tho secretarial organioation. The appointment gere him a titlo and an income; thoso rere by ray of reward. It gare him a place in the council; it was ouggestod above that that ras Crommoll's main purposo in making 1t. 1 It regularioed his position, but it gate him no nor

1. Above, pp.117I. 
adminiotrative porrero and didnot oooontlally altor hlo rolationship with Cromell. Ho continued, for inotanco, to follor cromoll on hio travolo and to rit to somo of his lottoro. ${ }^{1}$ Porhaps wo shall find that thooo provious funct ong of Mrlothooloy'a offor a now explanation why Cromoll divided tho oocretarjohip when ho relinquighod it.

The divioion of an offico thich had alrayo beon held by one peroon ia, after all, a lact which dosorreo a roally oatiofactory explanation. Loi ther a desire to refard tro faithful sorvanta, nor the intention of having two additional allios in the council, fully accounte for Crowell's action. Both these motives could have been ansrored more easily by the grant of different offices rather than by so otartiling an innovation. Iror rould they explain why the divialon becamo comon practico, only abandoned by the Cecils who wishod to gororn through the secretaryship. The rork may have becose too wach for one wan, but that seems hardly likely in vien of the lact that Cromell had himself held the office togother with his other poste for so many yearo. If it is objocted that ho had Friothosloy to look after the routine duties for him, and that routino combined with the higher level of the office was indeod too wuch, It must be anstored that eren after April 1540 the divioion of duties continued ruch the samo, rith Driothosloy and sadier

1. L.P. $2 \nabla .469,662$. 
doing littio but oubordinato and routino rork. Porhapo orommoll loared to raibo a rival for himooll. Ir, for a blanco at his rolations with tho socrotarios aftor April 1540 ohoro how thoroughiy ho kopt thon undor hia control. Thilo Crommoll 700 in porfor thoro novor rao a rival to hirs in tho odpiniotrative oyotem, and hardly ono on the council. Such $a$ foar rould have boon unnocosiary and dooo not, thoroloro, provido a oound reason for tho appointwont of tro oocrotarioo. Theso aro that might bo callod political oxplanationo; perhapa ro shall find a botter anowor if ro look at tho adminiotrativo aspoct. Friothooley 780 Cromoll's "undoroocrotary", while sadior had boon for wany yoaro practically tho king'g private secrotary. He was on Crownoll's otaff as lato as Septomber 1535,1 but from tho beginning of 1536 to tho dato of his promotion he was norwally in attendanco on the king and ectod as intermediary botwoon Honry and hio minioter.2 Tho promotion of these two wen made no differenco to thoir ophoreo of action, and Sadior continued to roport to Cromell on Henry'a Vierso and instructiono 80 ho had done boloro. 3 Very interesting io Cromoll'o answor to ono ouch lottor, for it is in Friothesley'o hand; 4 Cromell ueed the oecrotary who woo with him to writo to the one who ras with tho king. It 18, there-

1. L.P. ix.466.

2. I.P. X.76; xi.501,1124; xii.II,App.44; xiii.I.1375; II.178; XIV.I.236,579.

3. L.P. $2 \nabla \cdot 468,719$. 4. Ibid. 469 . 
fore, suggostod that the intontion wao to haro ono oocrotary permanontly in attondanco on tho king and tho othor pormanontly in cttonderco on tho lord privy noal.

From an edrinietrativo point of viom, this is by far tho moot convincing motivo yot brought forrard; nor is it roakonod by tho lact that the varrant appointing tho tro socrotarloo wan dofinito on tho point that both fore to have lodeling in court and Fore to accompany Crownoll thenovor ho ras at court. Hothing ros said about what ras to happon thon Crors:011 was out of court, bat it ras for this contingoncy - a erougent ono in practice - that the doublo appointmont was mado. Tho ling noodod a nocretary, and Cromsell oithor had oo or mahod to gurrender tho offico of principal socrotary; ho thoroforo took the step of dividing the offlco for cound administrativo reasone. The cese for this thoory is atrongthonod by tho fact that tho prify council of theos yoars was in tho havit of oplitting up, some of ito mowbers attonding tho king and nomo tho lord privy ooal; $;^{1}$ it wast have soowod highly docirablo to hovo a principal socretary with oach part to propare ito agonda and ottond to ito docioions.

Thus the position in the adminiotration of Cromoli's "undersocretary" ras rogulariood by tho varrant of April 1540 which appointed hir and Sador joint principal oocrotaries.2 
Erory rord of that marrant malioo it plain that tho offlco rao to romain ono, to bo oxorciood togothor by tho tro holdoro, and tho nost convincing oxplanation for thio otop is ono basod on administrativo purposoo. The tro mon had acquirod cortain oxperience and knorledge pihich thoy carriod oror into their not apppintment; ono remainod tho king'o privato vocrotary, and tho other tho lord privy ooal'o chiel clork. Onco again Cromolt has shom himself to be at hoart an adminiotrator Who applied to probloms of govornmont solutiono rihich without any dorogatory intention wo may call buroaucratic.

Cromell had mado himoolf hoad of tho socretariato by acquiring the officoo of socrotary and lord privy ooal, not to montion his temporazy control of the chancory clorko through the mestership of tho rollo. Furthor, he carriod on hio government through tho clorks of his orn privato offico, his orn household servanto, who handled his porsonal correspondonco by means of which ho so largely adminfotered England. Ho intendod to regularioe the use of the oignot and prify goal in tho chain of marranty to tho great ooal, and then procoodod to orade thow both for the oako of adminiotrativo convonionco. In oider to free himoelf from the rork of dotailed suporvioion, he virtually appointod his chiol clerk, Thomas Mriothooley, to a pooition which wo havo folt justifiod in doscribing as an underoocrotaryohip. The wain improscion dorivod from a otudy of 
this aopoct of Crowioll's rork to ono of groat poroonal control and autocratic uso of tho machinory on tho ono hand, and on the othor of a roforming and organiaing actiogty rhich aimod at tho creation of an officiont buraaucracy. 
Chapter 5.

THE COUNCIL.

\section{The Council bolore Cromoli.}

In tho courge of our invootigationo to havo ofton referrod to the "government" without giving any dofinite meaning to that term. The truth is that no definito moaning can attach to it, at any rate not until ro can bo cortain of tho oxiotonco of tho Iully developed prity council. The government of England was in the hands of the keing and of ouch mon as it alght please nim Irom time to timo to ontrust wi th oxecutivo funetiono. However, there had grom up a body of men rho, becauge of thoso functions or because thoir advico mas babitually sought, forwod sowething of a more permanent govornmont. Tho king's council, differentiated or not, contained those people and fnotitutiono which we agsociate with the nase of gorernment. In a otudy of Cromell'o adminiotration, hio rolations with the council are therefore of paramount importance. Deopite the fact that ve have often seen hil in quite undioputed control, or only controlled by the king, deopite the lact, too, that hio adniniatration ras a wost porsonal one, it is plain that re cannot ignore the other councillorg of the crorn, especially in their corporate capacity. Cromroll might bo oupreme but ho ras not alone. Horeoror, it must bo rememered that his fall 
was followod by tho rapid ootabliabment of a formal innor council which rao to bocome the elot charactorlotic odminiotrative institution of tho oixtoonth oontury. Thore aro, therefore, threo queotiono requiring attention: That happened to the council duxing Cromroll's supremacy; that roro crommell's relations with tho council; and can ro find any trace of a growing privy council which would explain ite oudden appesrance in completed form two monthe aftor cromoll's arrest.

While, thon, the council io a noot important problom in Crowell's administration, none lo moro diflcult to track dom. Attempte have been made to clarify the history of the council belore 1540, natably in Prolessor Pollard's articloo, 1 but it aust be admitted that the light throm on the oubject 1s Lar from strong and clear. The concluoiono uaually adoptod way porhaps be otated in the rorde of one friter who asoures us that the council of the earlier part of Henry'o roign ras not a definite body but "ouch toam of councilloro as tho king was then in the babit of conoulting about that oort of buainesa", although groring habits of direct action and tho "proliferation of conciliar potenttalfty" as rell as as Rolooy's practico of excluding his enemios, tonded to fix the council's composition

1. A.F.Pollard, "Council, Star Chaubor, and Privy Counoit undor the Tudors", E.H.R., Xxxvil(1922), pp.33711., 51611.; Ixxvi1i (1923), pp.4211. 
and functiono. ${ }^{1}$ The lateot otudy of tho councll undor Holooy, baod on now and rathor otriklng oridonco of counc1l rocordo before 1580, indicatos that this fixing had progranood far by the middle 'twentios of the century. ${ }^{2}$ It io truo that tho "Ellesmere extracts" do not appear to ovorthror so wany accopted notions as Wr. Dunham impliob; no ono has doubtod tho oxiotonce of a king's council thich oat fairly rogularly, if only for tho hearing of potitions, and which by Holsoy's timo bad becomo clearly distinct from tho otar chambor. That wo ohould really like to knot is the rork which the council porformod under Holgoy, for that rould bo tho only rellablo indication of ito place in the adminiotration, and on that point tho article quoted dooo not offor anything revolutionary. It montione actions of ocandal, seditious rordo, extortion, porjury, and contempt, all matters which do not imply any adminiotrativo porere in tho council. Horioror, "non-judicial mattero ohor tho extent of the council's porror during tho frolooy régide". Those natters turn out to bo ouch thingo as tho owoaring-in of juatices of poaco, oheriflo, and nor councillors, the appointwent of councillors to the court of requooto, and the isopting of proclamations. $3 \mathrm{Nl}$ thio buginoso so of oopo intorost in

1. K.Pickthorn, Benry VIII, pp.1211.

2. R.H.Dunham Jr., "Tho Ellogmoro Extracto Lrom tho "Acta Congili1" of King تienry VIII," E.H.R., IViil(1943), pn.30111.

3. Ibid.., pp.312f. Lis. Dunham hag rorisod out tho dotailo in anothor articlo, which shome claarly that tho council undar Tolsey ras concernod almost oxclusirely with judicial 
adainiatration, but it is routino; it is tho kind of thing rhich rie should have to suppovod to havo takon placo in tho council oron if no oridonco could bo found for it. Tho council of Nolooy's timo appoars to ho a lone ray from tho privy counc1l of 1540 .

All tilo sarso, tho "Elloomoro oxtracts" aro of tho Erontoat irsportance, if only bocauso council rocords boforo 1540 aro no vary low. Thej propo tho exintance of a rogintor or ontry bonk earlior than tho regular oeriog boginning with tho appointment of Pagot as clork of the privy council, but it is mbst significant that tho oxtracta aro dated rith a clause rhich mentions tho lar term. ${ }^{1}$ so Profosoor Pollard has pointod out, tho privy councli of tho lator Midoro was distinguishod from its parant body by oitting all tho yoar round and not in term time only. 2 The council of tho "Elloomoro oxtracto" was thoroforo most cortainly tho old council and had not yet begun to devolop tho characteriotice of tho privy council. Somo of tho ontrios belong to the tiwo of Cromell'o ralo and indicate that tho registor, official or not, may haro continued until tho otart of the extant recards. 3 Hoirovor, the books are lost, and tho hietory and tho placo of tho

business and did not suporvise tho adminiatration (iI.If. Dunham Jr., "Tolooy's Rulo of the King'o Tholo Council," Amer.Higt.Rev; XIi工, Pp.64411.).

1. E.H.R., IViii(1943), p.302.

2. A.F.Poliard, Folooy, D.111.

3. E.H.R., IViii(1943), p.315. Nr.Dunham Givos no dotailo. 
council have to bo roconotructod from othor ovidonco. Thoro io somo; among tho otato paporo pio ind an occanional rocord of businoso dealt rith, and tho council is montionod ofton onough to allow somo degroe of cortainty to our conclualono. of particular importanco in thio connoction aro tho roporto of foroign ambassadoro to England, and ro can arrivo at oomo knorledgo of the placo of the council in tho highor ophoroo of doliberation, and by inforance aloo in adminiotration, if Wo consider with whom the ambasoadoro tranoactod thoir busino80.

One Iurthor complication mast be wentionod. A roforonco to tho king's council bill often, on closer inopoction, rovoal itoolf as concornod not fith tho council which 700 to dorolop into the privy council, but fil the king'o legal counsolloro who had bocomo a diotinct and soparsto group cortainly by tho time that the business of the dirorco otarted whon they roro ofton conoultod on logal pointo. 1 Caro unsot bo takon not to confuse thom with tho lorgor unit, tho council as an advioory and governing organisation.

Wo may otart, thon, from tho lact that thoro rao a covorning council under Volooy, a body of fairly lixod compooition which met regularly to transact businoso. Tho quootion 10 rhat kind of business it transactod, and hor wach of tho actual

1. CI., 0.g., L.P. iv.5155,5177,5741. 
govormment of the country lay in 1to hondr. Evon wh1lo ho wan otill in porer Nolooy's onomios rioro thinkeng of accuring him of packing tho council and porvorting juotico in cason that camo bolore it, 1 but of Eroater intoreot aro tho accuoationo lovelled against him aftor his fall. Those ohor that whilo ho did not govern entirely without a council ho kopt offoctivo governsent in his own hando. Ho wao chargod with stopping discussion then hio policy riso questionod, and with boharing with such arrogance that he allorod but ono or two of tho greator councillore to havo any say at all. Also, it ras alleged that he deprived the council of information and tranoactod foreign policy without roforence to it. ${ }^{2}$

A oimilar picturo can be dorivod from tho roporto of ambasodors. In forty-three reports, coverine roughly the yoar 1528, the French ambasoador du Bellay told constantly of nogotiations rith Holsey, and norr and egain rith the king himoelf, but not with the councll whom ho seoms never to havo met as euch. 3 Trice he rao receired by Foloey in the prosonco of

1. Ibid., pp. 2560,2551 .

2. Ibid. 6075 . Tho points avout the council aro $9,10,12,15$. In 1518 Thomas lfore told the Vonetian ambassador that Volsoy transactod all buginess with the Fronch ambasoadors, calling the council only when the negotiations wore ovor, so that oven the king scarcely knem that ront on (Von.Col.

3. L.P. iv. App.123-30,135,140,142-4,146-9,153,156,158,163, $265-6,168,175,177,179-80,186-7,190,192,196,198-200,203,206$, $212,215-6,219,223-4$. 
othor councillorg, but in both cas0o it was tho oaralnal who conducted the negotiationo, and tho othora a0om to havo dono nothing but add woight to tho procoadingo. 1 Tho roportn of the Vonotian ambasoadoro for tho yoars 1528-9 add furthor proof: all businosa wao transactod with folooy to whow a now ambassador actually prosontod hio crodontialo on arriral. 2 Yot tho ambaosadors woro in touch with tho wombors of tho council, for in January 1589 du Bollay roportod that Gardinor'n migeion weg kept gocret oron Iron many of the councilloro.? But thore ras no formal and official contact with tho counoil, and in mattero of momont, particularly in foreign policy, Molsey gororned without tho council. 4

As one rould expoct, tho picturo changos noworhat with the approacin of hio fall. Other nowoo como to the fore, llarfolk, Sulfolk, Rochelord, Gardinor. 5 In Boptombor du Bollay wished to introduce a spocial onvoy not only to tho king but also to some or the council, though he st1ll thought that tho wan who mattorod was Hology. 6 Nogotiations mbout the troaty of Cambrai vore carriod on in tho prosenco of king and council,

1. Ibid., App.158,166.

2. $\frac{\text { Ven.C8l. }}{463,492}$ iv. $235,249,285,376,385$ (the crodontials), 420,461,

3. L,P. iv. 5209 .

4. C1. A.F.Pollard, Folgoy, p.111: "Tho irruption of his dominent peroonality into tho king's ontourago intorruptod tho growth of tho privy council and reducod it for tho timo to political and constitutional insignificanco."

5. L.P. iv. 5885 .

6. Ibid. 5945 . 
and though the council who roro ouppoood to bo cloaring up oomo tochnical afficultion roro nlmont cortalnly tho king'a legal counsol, thore is mach olgnificanco in du Bollay'n roquest that tho good oorvicoo of Borfolk, Suffolk, and Rochoford bo romomborod, and woro in his roport thet nolnoy nao unlikoly to como to London for a council mooting. 1 Torards tho ond of soptembor it rao thought iwportant to doocribo rolooy'o attendanco in tho council, rith and rithout tho king; tho council wao gaining woro and waro influence oo molooy'o otar ranod.2 Early in octobor the king askod du jollay to rait till the council camo to London from ifindsor boforo rolating hio charge to thom; though they mot at riology's houso it moant oowething rhen his buginose could no longer be put to alone. $3 \quad \Lambda$ fer dayo lator du Bollay rocolvod hio answor from the council; tho king had rotirod to windoor loaving it bohind, and both the French and the imporial ambasoadore had conforrod with it. Tho council rao beginning to rosomble the lator privy council in that it tranoactod important govommont bualnoss with and without tho king, though unliko the privy council it did not follow hiw rhorever ho ront.

Thoro rag littlo chango from thio aftor Molsoy'o fall. Tho ambassadors roportod that all porror had now Eono to tho

1. Ibid. 5911.

3. Ibid. 5982 .
2. Ibid. 5953.

4. Ibid. 6002 . 
duko of Norfolk, rith Suffolk to asolot him, $n$ vion confirmod by Folior's report lato in 1531 and shnrod b $\because$ nuch o londing

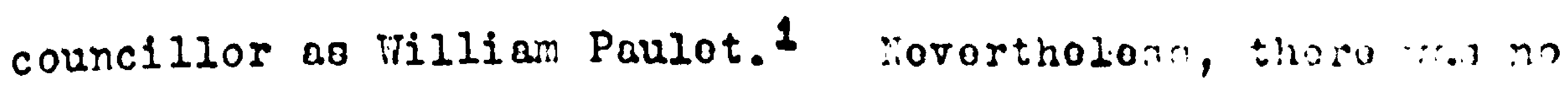
quostion of Norfolk succooding Molsoy in tho solo man:iumont of affairs. Chapuyo might occasionally dineusn no.tors rith nim alono, 2 as at other times ho night woo only tino king, 3 but it vao comon for the king to refor t: the council and for the ambarsador to moot the council in formal ronsiono. Tho state of affairs is ovon clearor frot the roports of the Vanotiar. anbassador. Ho oan Norfolk vory raroly, and thor uaually becauso he could not soo the king or becaugo Henry sont hils to tho duko. 5 osten ho sar tho king alono. 6 At otiner timoo ho met the council in sosion: in liorfolk's absonce loro did tho talking; another timo lorfolk road him a lotter from tho king; then again he "spoko at great longth... in the counc1l chambor". 7 Then a apocial onvoy arrivod frow tho enporor he $60 \mathrm{dr}$ tho king and tho leading councillorg, declared his chargo to tho king in council, anc hold sovoral mootings with both. 8 The council of the jears between the supremacios of liolooy and

1. Ibjd. 6011,6018-9,6026,6030; Von,Cnl. iv, 5.294; L.P. iv. 6436.

2. IR: $\nabla_{0} 148,308,805,832,879,1131,1292$.

3. Ibid. 941,1633 .

4. King rolors to council: ibid. $40,105,287,773$; Chapuys and others meet tho council: ibid. $45,216,251,563,1013,1633$.

5. Ibid- 824; Ven.Cal. Vi.733,744,761.

6. Ibid. $563 ; 576,608,686,726,763,782$.

7. Ibid. 718,726,834.

8. L.P. V.564. 
Cromoll conductod foroign affal ro ao a govornwont, though tho porsonal activity of tho king ros o now and vital factor. An oxample of tho not opirit in tho romboro of tho govornmont is givon by Chapuys who roportod dioagroskont in tho council ovor tho proposod intorvior botroon Honry and Francio I in Soptomber 1532. The king was dotermined on it, but thoro wao much opposition frow tho council, lod by suffolk and tho oarl of oxford.1 Thio nas indood a councll mich dooorvod tho namo of governmont, ovon though thoro is no doubt that tho last rord, and wany an oarlior one, loy with tho king.

Wo now aloo got an occarional glimpoo of a council activo about administration at hore. It continuod to doal rith thoso watterg which the Elloswore oxtracto ohon to have boon 1 to rork oven under Molsey. Potitiono voro rocoivod, criminalo brought beforo it (by tho king'o ordero), and Cromoll ras rotainod by the earl of 0soory to pur his 8880 to king and council. 2 In lrovomber 1532 Audeley, koopor of tho great oeal, oont Cromroll a detailed report of tho appointuont of ohoriflo, ono of tho Itows in Ur.Duxhom's list of council activition: tho lords of tho council, the justicos, tho barons of tho oxchoquer, and the master of tho rolls had aoserbled in tho oxchoquor to nowinate threo peroono for oech oheriffrick, and a list had gono

1. Ibid. 1292.

2. L.P. iv.6571,6586; $\nabla .360,688,1061$. 
to tho ling for hirs to prick hio cholco.1 Lono routíno mattors also ongagod tho council's attontion. Tho king rino roported to bo discusoing tho divorce fith his council, throatoning to oottlo it by thoir advico and that of parliamont. 2 Bolsoy rocoived a lottor from ono of his agonto ribo offorod to got woro inforwation in a lottor frow the king or tho counci1. 3 In liovomber 1530 Chapuyo roportod that tho king had complained to the council of oomothing that had not boon dono to his liking, saying in a rago that Holooy was a bottor wan to govern than any of them; tho implication io that important detaila of adminiatration rore handled by tho council, though we do not know exactly what they roro bacauso Chapuys failo to tell us. ${ }^{4}$ When a ropreaentativo of Holooy'o collogo in oxford triod to obtain a rit of auporsodoan from tho chancory to atop procoodings againot tho coslego, ho had to rait unt1l tho council witharen their objection; tho council had also discusae? and doterminod what was to happon to tho collogo. 5 Host oignificant of all ia the groming practico of roforring to the inner ring of the council as the prify council. Thoro are sercral exapples which indicate that somothing of tho kind w88 beginning to bo officially recognioed, though nono of them prove the definite and soparate existonco of an organlood privy

1. Inid. 1518. A duplicate list 708 sont to Cromell.

2. L.P. $1 \nabla .6307$.

4. Ibid. 6738.
3. Ibid. 6390 .

5. Ibid. 6666,6679 . 
council. 1

It noedod tho doparture of the king to bring about tho cloar cogregatton of a govorning council. Mion llonry ront to France in the auturn of 1532 ho took rith hin such londing councillors as the dukes of liorfolk and Suffolk, tho marquoso of Exeter, the oarlo of Surroy and 0xford, tho blohopo of Finchoster, London, and Lincoln, Crowioll and sampoon ítho dean of tho chapol), and many othoro of 1000 importanco in politice.2 Ho did not eppoint a ragont or lloutorant, an omisoion ribich led to difficultios in tho adrinistration of juotice, 3 but loft bohind a council consiating of tho orchbishop of York, the lord koopor of the groot nool, the oarl of Sussex, lords Darcy and Tindoor, chiol justico Fitajamoo, Richord Tolman, Sir Joln Daunco, Sir Brian Tuko, Sir John Aloyn, Dr. Tregonroll, and Thomas Lodoll.4 Thio wixturo of great nobles and churchron, judgos, civil lanyore, and clorko zes typicel of the council as a whole, and tho council loft in London was a croos soction of the parent body. Of its nomberp, only Auddioy and Sussox rore lator to bo privy councll10r8, which indicatos that Honry took noot of tho "innor ring" with him. 5 Inotructions had boon lolt for this council, 6

1. E.g., L.P. $\nabla .1025,1029,1245,1406$. Cf. Follor's roport, Ven.Cel. it, p.297.

2. L.

4. Ibid. 1421.

6. L.F. $\nabla .1408$.
3. Ibid. 1430.

5. CI. boloti, p. 433 . 
but thoy roportod rogularly to tho kins, and ooro of 1 to mowbern corrospondod with tho councilloro tho accoupaniod Honry to Calais. 1 The councilloro in Franco, on tho othor hand, gont norro back so ao to koop tho council informod. ${ }^{2}$ Thoro was no thought that tho council in London in 1 toolf conotituted an indoponcent Eovornment; on tho contrasy, noarly all tho loading councilloro, who had gono with tho king, oxpoctod to bo kopt informod of what ras going on durine thoir aboonco. 3 The council in London ovon had to Frito for apottal porminotion to opon lottors from scotland. 4 Tuo council cat ovory day, 5 an arrangoment so novel that the attomoy-gonoral comontod on it rith a aixture of supprise and satiofaction, conoidoring it expodient nor that tho king ras out of the country. 6

Horiover, thet wattero is that wo have hore a council rhich in composition, function, and procoduro :as a omallor edition of the council wich nomally worked in attondance on tho king. It consiotod of relativoly for momboro, on to tho adrinistration of the rhole country, not daily in the council chamber, and kopt in closo touch vith the king. Thooe foaturos, we soo no roason to doubt, must havo boon frirly typical of tho normal council for thich no ovidenco surviveo bocaure, boing uoually with the king, it rould not ofton roport in

1. Ibid. $1408,1421,1427,1430,1444,1450,1473,1542$.
2. Ibid. 1531.
4. Ibid. 1450 .
3. Ibid. 1430 .
6. Ibid. 1444 .
5. Inid. 1473. 
iriting. To may 7011 bolloro that in ordinary circumatancoo tho prosonco of tho lifing, or of cuch chiof counclilloro as liarfolk, vardiner, or - hy thiu time - Cromsoll, wollin out dom the wori: dono by tho council as a wholo, but tho council loft behind in London shows the noturo of the council that had Grom up sinco rolsoy's fall. It rns this counc1l, itn mothodo and potentiol porero foreohadoring tho privj counc1, which under the king conductod the jovernmont of tho country when Cromell entored on his supreascy. iro must nor noo how it lared under him. 


\section{The Council under Cromroll.}

During the yonro 1533-40, wen Cromicll :no tho king'n chiof ministor, tho rork of tho council ir not ro obscuro no the absence of regiotors might load one to bolfovo. Tho ovidonce is to a cortain oxtont erremontary, but from notos and roforoncos strotching ovor tho rholo porlod it is ponsiblo to reconstruct a tolorably corplote picturo. Fithero thoro io evidenco for certain sctivitios at noveral pointe throughout those eight yoare it is permisolbio to ansume that auch activities took place during the intervals when the ovidence failo us. Roforences to the council miltiply, and for 1533 tho index of the Lettors and Papora, Fith tionty itoms, bocomos for the first timo rearonably completo on this oubject. Tho firo referencos in the index of volume if (1524-9) and the tro on that of volurse $\nabla(1531-2)$ do not, indoed, reprecent the total of nentions in the text, but thoy indicate the fact that tho council is rot mentionod ofton and could appoar of littlo importance to the oditoro of the calondar.

Tie have ooon that by the end of 1532 the council regularly occupiod itsolf with tize discuesion and execution of both foreign and domestic policy, in a manner rhich ousgootod the work of the fully dovolopod privy council. Inder cromill It continued this rork. Arobasoadoro rore constantly boforo the council, to doclare thoir buoinoso, to discuso pointo at 
Locuo, and to rocoivo information. Chrpuya' toatinony is particularly otrond for the oarlier part of tho poriod bocauro his reports wore thon fullost. Tho council informo hit of tho king's proposed marrigge to Anno 3oloyn, though hin annvor Jas no unsatiafactory that they had to rofor back to tho king. ${ }^{1}$ Lattero of trado rero dibcussod froquontly. ${ }^{2}$ iio had a lone meeting vith the council in lay 1534 thon ho wao informod of tho pagring of the act of auccosgion and pranglod with Foro, Tungtall, and others about the obotinacy of Katharine and iary in refusing the oath. 3 Fhen wary fell ill lionry ordorod tho council to inform tho imperiel ambassador. 4 on anothor ocsasion Chapuys hold a discusnion ifith tho Fronch ambaosador before the council.5 lior rias ho the only asbaooadior to attond the council. The 8cots dia so, as woll as tho Lubocisors and other German envoyo.6 In 1538 tho French ambaosador, Castillon, ras before the council with considerable and ineffoctual froquency, and his succossor, warillac, kopt conine up to discuoo somo troublo that had arioon in connection with a Frencb worchant. ${ }^{8}$ Altogether the council zas kept protty busy with watters of foreign policy.

It rould, horrever, be wrong to suppose that ambassadoro
1. L.D. Vi.720,805.
3. L.P. Vil. 690 .
5. L.P. xi.7.
7. L.P. xili.I. $623,629,843,855,909$.
2. Ibid. $975,1018,1112,1125$.
4. L.P. Vi11.189.
6. L.P. Vil.662,888; xiv.I.1092.
8. L.P. Xiv.I.1261,1301,1316; II. 656,743,779. 
invariably diecuoood buolnooo with tho council, or that tho king's foroign policy rao nocoobarily docidod thoro. Chapuyo throws some light on llonry'o attitudo whon ho roporto that ho gas informod by the duko of iorfolk, in a council wooting Which incidontally did not include cromoll, that tho kine rould woo him if tho mattoro about which ho had cowe rore of importance; if they wore not, the council rould eottlo thom. ${ }^{1}$ ambassadoro sometimos bart tho king alone, or with only ono or trio of his councilloro, or thoy aight diocuse mattoro with cromell. Thus after tho sosoion in shich he had fought tho council over the queen's disobedionco, Chapuys had a privato conversation with Crowroll in which ho tried to put hio moro intinate thoughto. Crompli aight oometimos profor to tako the lead in the council rather than conduct foroign policy on his orn, as, for instance, in the nogotiations rith Castillon alroady reforred to, but it was most usual for hit to hold conversations with foreign ambasadors array from the council, and references to such convorsationo can bo found in tho rast wajority of anbassadorial reports scattorod over the yoars of his supremey. The ezamples of council activitios which re have given indicate what the practico was. Thilo negotiations wore carried on by the king or Crowroll, tho more formal business as well as tho losoer watters noro dealt with in

1. L.P. Vii.726. 
council. If an ambassador was to bo givon tho improoalon of a government united on major aopects of pollcy ouch ad tho anti-papal legiolation, or if he was to bo oolomnly informod of certain stops takon, or if hio buoinoos wao of comparativoly little importance (as for instance temporary difficultioo in the rool trado), he rould 800 the council. The ronl doctolono in foroign policy were made by tho king, or oowotimos by cromwell, and the important discusoions in which the diploracy of tho timo was carriod on roro hold chiolly with tho lattor. 1 Thero are oome indications that torardo tho ond of hio life Cromele nas allorod loos froodom in conducting forolon affairo, with the rosult that the counc2l casso moro to tho fore. To have alrosdy ooon that Castillon, in 1538, nogotiated with tho council, though it ras usually crowroll who spoke at the mootinfo. Interesting ovidenco is providod by the reporta of the ambasadoro of the Schralkaldic Loaguo who vicited England trice in 1539.2 During thoir firot ombassy

1. By ray of oxample to rill givo an anglysis of tho ovidonco for the tro years of Cromell's highest porror, 1534-4. During those yoars Chapuyo' reports are frocuont and full. He aar the council hardly ot all (Span.Cal. 1534-5, pp.170, $219,479)$; the king 80 raroly, though tho mottero discusood rore more inportant (ibid.' pp.569,5991.); ilorfolk occanionally (ibid-, pp.6111.,279,33011.485); Crois:011 conotantly (ibid., pp.125,21911., 29411.,301,41311.,42311.,432,43611., $45411 ., 46511 ., 47611 ., 49911 ., 534,55311 ., 59011$ ). It 700 , moreover, in his conversations rith Cromerell that Chapuyo regularly diocussed all the points affoctine relations botroon Englend and tho omperor.

2. Printed by Lerrinan as an appondix (i.27211.). 
thoy arrivod in London to find tho king abaont, and thoroforo prosontod themgolvos to Eromroll. Lator tho ising hoord thoir mogonge in a formal sosolon of tho counall, and furthor nogotiations roro carriod on rith Cromroli and a part of tho council either at st. Jameg's or at Cromoli's houno. Thuy had no furthor convoroations with Crom::oll alono. Thoir ambassy was largoly concornod rith tho quontion of an nillanco betisoen England and tho Loaguo, and tho roport makoo it cloar that tho king'o main purposo rao to provont the concluaion of any definite agroomont. Tho mootinge roro conotontly put off, bocauso Cromoll wao itl or bocauso tho councilloro noro buoy in parliamont, and wot of tho timo was opont in diocuoging the insufficioncy of tho ambaosadorg' porroro. Tho uso of a council co:mittoo may havo boon intondod ao a furthor check on Cromoll riho would undoubtodly havo likod to come to an agroement.

The envoyo fared differently on their oocond vidit. Then they oaw Cromell or tho king or both together, but no ono 0180. Though the question of tho ollianco rao dhocuoood at longth, many minor pointo and diflicultiog woro oloo brought up. Eorrever, the subject of the socond eabasoy ras not 60 different as to account for tho differonco in trontmont; tho real differonce wao that thio tiwe Lonry'e mind vao made up and tho delaying tactico of tho provious vioit woro unnococoary. 
Tho council war uood to chock Cromkell vihon hio pollcy vico in opporition to the king's, but by tho ond of 1539 ho had himsolf roalleod the failure of the Luthoran ollianco and woo acain rorking on the camo lines as Honry.1 Hithout ancribing too mach importance to tho part playod by $n$ for councilloro in thooe nogotiotiono, re may novortholosn 800 in it a olgn that the council, which had handled e. good doci of foroign policy since Folsey's fall, ras bocoming moro lmportant in that flold ag Cromell's fall approached.

Diplomacy mas by no moans tho only point on tho council's agonda. Aflairo at Celais, for instanco, wero ofton discuogod. A represontative from that tom was heulod hoforo tho council but could roport that on the rhole the doputy and hio council had come oft riell.2 Thore rao "the Eroateot rumo" when the king and council took up a Calale proclamation, though the troublo blow ovor. 3 Tho courcil rio pregent whon tho king, secondod by lorfolk and Cromoll, declaroc his rogard for the deputy to tho combiosionors who in 1535 lad invostigatod matters at Calais, and it ras in tho council thet tho ordinencos dram up by them roro discuseod. 4 Thoy roro approved, and tho dobate turnod on tho quostion fhothor it rould bo rioor to embody thow in an act of parliamont or in a council ordinanco

1. Cl. Lorriman, 1.2561.,26411.

2. L.P. $\nabla i i .310$.

3. Ibid. 386.

4. L.P. Viii.912; ix.766. 
omanating from tho king. In 1537 Cllalo croppod up again, and Lord sandeo, the captain of Guignoo, fornonally roportod on the otato of tho tom and ita onvirono, flrot to tho king and cromsell, but aftorrardo to a full oosnion of tho council. 1

It rill bo uogful to compilo a liot of mettoro knom to have ongaged the council's attontion. The ovidonce is Bcattored throughout the otate poporo, and brought togothor horo it will indicato tho rido ocopo of the council's businooo. The council proposod to prohibit groa: acoombllos of nrmod poople, discussed the corier lands of quoon Katharino, Invostigatod the navy and 808 fortiflcations, outhorinod tho inouo of a pamphlet justifying Eonry's oocond warriage, discursod tho Eenoral council of the church nnd rolatione rith tho om peror, ras very busy conghdoring a meo0ego brought back from France by a opecial envoy, dobated and cottlod parliasontary busindss and the euccosion, corrospondod rith Reginald Polo, ras informod at once rinen a courior arrivod from tho Lotherlands even though the lottors ho brought rore for the king and Crom:ell and tho lattor rias aboont, itsolf authorioed the doopetch of moseongers, and res cailed by tho king to discuso lettero recoived from Cromell in rich tho lattor roportod diplomatic negotiations.2 Tho varied naturo of tho council's

1. I.P. xii.II. 802 .

2. L.P. vi.720,1510,1571; vii.1; viii.660,820; x.635, 1069; xiI.I.125,444,1009; xii.II.1280(nassith) xiv.i.236. 
concorns eppoaro clearly frow tho for notoo of buolnosn tranoactod, or to bo transactod, which ourvivo. In 1533 Cromioll put down somo wemorando for the council which includod novoral decisions rogarding tho troubloo in Iroland, a lottor to Lord Dacro, "the supplycrayon of tho sorgoauntt for tilo roncus", "tho byll put Agoynot my lordo darcyo for tho kyngo wanor of Rowthwoll and of the docayo of $x \times x$ plowoon, and conothor potition alleging wronglul inprisonmont and tho obbozaling of load. ${ }^{1}$ In 1537, lists of wattore put boforo tho counc1l wentionod tho defonce of Calais, Bertylck, and Carlislo; tho gaining of diplowatic Iriendghtpa by warrying off at loaot ono of the royal princessoo; tho navy; woasuroo to prosorvo tho peace at home; lottors to local magiotratos and noblowon to wako sure that they spont at loast ook0 timo in thoir om counties; an attempt to rostrict commisaions of tho poaco to wen of "worghip and rigdom"; tho council of the north; prom visiono for the king's housohold; the granting of a gonoral Ireodom in the hope that tho profits of tho soal fould mako up for all other $108000 .^{2}$

These liats opeak for thomoolvos. Tho council wos kopt Iully occupied about wany different aspocto of tho gorernmont: foreign affelro, homo affeirs, dofonco, affulrs of tho king's dependencies overseas, tho housohold, potitiono, administrativo

1. P.R.0. SP 1/76, 1.137 (L.F. Vi.551).

2. L.P. Xii.I.815; II.177. 
projocts. Thooe roro mottoro of polltical or adminlotrativo inportanco; thoro mat bo addod tho cosos docidod or diocunged before tho council, and the apponrancos ordorod of mon concornod in ouch cosoo rhich might bo political and cribinol Q8 roll 88 civil. Evon tho otato paporo oupply an Iupronolvo 11日t, and wo can only rondor what the full oxtent of such business rould appear to havo boon if ro poosoobod a comploto council regloter. 1 Reporte abound of the council'n buay-noso. In April 1536 thoy oat ovory day, diocuooing lottoro from Frinco, and in tho ond could not como to a docioion although they sat from early morning till nino or ton afnight. 2 vory ofton they woro so busy with affairs of otato, dospito dally meotingo, that they had no timo to oparo for oultora.3 Horo agein ro must notico thot wost of tho roporto of daily olttings, of mootings lesting all day, of groat activity on tho part of the council, occur towards tho ond of cromrell's rulo, 1ate in 1538 and in 1539. Thoro is, then, no quootion of tho council being pushod into tho background, or of cromoll trying

1. Cases beforo the council: L.P. Vi.818,1059; 1x.191,411; x.765,1101; xi.166,300,365; 2ii.I.152,837; II.1018, 1325; xiii.I.615,735; II.6,387,1246; IIV.I.1271; II.351; 27.56, 128; Add.1018,1030. Appoarancos bolore tho council: L.P. vi.945; vii.480,641,694; viii.43; ix.150,369,670,760; $x_{0}$ 1027; X1.158,226,696,1232; x11.I.80,782,1192; II.691,694, $817,886,1118,1134,1208,4 p p .41 ;$ xi11.I.307, 1117; II.4, 18, 110; Iit.I.358,800,1114; xण.105,252(ii), 106 .

2. L.P. $x .748,752$.

3. L.P. I.789; XI11.I.91,659,1149; II.605,703; xiv.I.381. 
to do Fithout 1t, though tho activition of tho councli rarit not load us to suppose that tho; had erostor porer than wao actually the caso. To shall dincusa cromoll's rolationo With the council lator; whot re rioh to dincovor horo in the. kind of councli thich mot durin; his ouprowacy. In tho ocopo of the mattors brought beforo it it rocomblod the future privy council rather than tho ohedory and ill-nttondod body of rolsoger timo. 1

The crisis of the pligrinage of graco ohoriod tho counc1l in greater indopendenco than it achieved in norral timoo. It was no doubt thought advisable for Cromsoll, whose wule tho robels had wade one thoir ciliel pointe of attack, to romain rethor more in the background. Far somo part of the time that the troubles ladted ho res in London, looking after tho auministrative cotailo of the fight agsinat tho pilgrimg, whilo tho king and tho councillors with hin conductod policy. Ho Fos novor unoeated, for at no timo ras ho loft uninformod of what zent on, and his advico and action rore in conotant docand. It ie, horever, oignificant that noot of the reparte from tho north rero addrosod not to the king or Cromroll but to tho council. Thus llorfolk usually uroto to "wy lordos" or "ay

1. Honry had complainod that Folsoy in tho atar chambor ourrounded hicoolf with Eoro councillora than bo allomod to the councll attendant on the king. Prof. Pollcred has apokon of the contrast botroon tho "inpreseivo attondanco at tho chancollor'o court of atar chambor and tho ocanty at tandanco on the king ubicunquo fuorit" (iiolgoy, p.110). 
vorey gode lordos of tho kyngoo moot honorablo counooll", 1 though bo wight loo wito concurrontly to cromold. 2 Fihon Paulot and xingoton ranted wonoy thoy adirodool thowsolvon to Cromell and tho council; as Crowroll rao : ot thon with tho king, tho council answorod alono, ordoring thow to apply for the coney to tho jord privy soal in London. 3 Roplino to lottore from tho various commandoro in tho slold and inotructiono to thors roro norwall: vition and signod by tho council as a 7holo. 4 Though Cromroll rias uoually ono of tho nicmatorioo and might oven, in a council lotter, wito in tho ilrnt poroon oingular, 5 the sionificant point is that tho councll actod ao a body and the conduct of businoss ins not loft to Cromoll alone. The occasion $\because$ as an unusual one, and ao has boon sald there rere sound roasono for making it e.npers that Crommoll rao oclipood; moroover, tho fact that tho wholo council oignod theoe lettors and roceived tho reporte doos not provo that pollcy did not really continuo to be in tho handa of Cromioll and Ecnry. Horever, tho fact romaino that ao oarly ao 1536 tho

1. L.P. xi.775, 825,909, 921, 1242; xii.I.319, 321,332,398, 468, 594, 651,916 .

2. Cf., o.g., L.P. xil.I.310 ioorolk to Cromoll) and 310 (Vorfolix to tho council), both writton on 2 Fobruary $\$ 537$. Ibid. 293: Norfolk riroto to Cromroll that thoro was no norro axcept rhat ho had iritton to tho king in a lottor rinich rould ilrot como to Cromsioll'n hand.

3. L.P. xi.803,823.

4. Ibid. 701,788,799,836; xii.I.291,332,333, 505, 558,636,667, 846,864 .

5. Ibid. 846 . 
councll had dovolopod to a pltch whore it could moot rogularly to decido vory vital inoueo and rao copablo of adalniotoring ito dociaiono. Ito composition vill concorn un lator; horo It vill bo onourit onco zore to romind ournolvoo that tho council of the 1530'0 rias an actiro body ihich doalt rith many aspects of tho zorornment. Unlliso Holooy, Cromsioll mado no at teapt to rule without a council. 


\section{Groproli end the Council.}

Tho question not arloos how Crom:oll roconollod hio por ponal actirity and accondancy ilth tho orintonco of a counoli that rao busily and constantly rorking on wattors of polley and adminiotration. It may firpt bo noted that ail the counc1l business rhich has boen diocorerod has contalned hardiy a tracc of inancial affairo. Tho colloction and oxpondituro of rorenue ras apparentiy not discussod in or controllod by

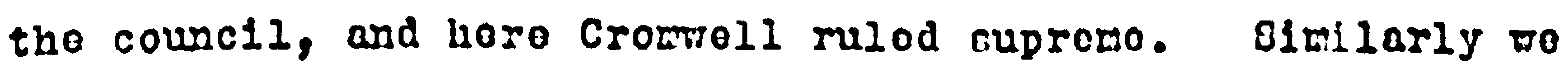
have found no oridonco that the council concorned itrolf with the supervision of the sorement socretarlate. To the bont of our knorlodgo, theoe tro branchoo of the adwiniotration werc loft ontirely to Cromell ribo thuo had a froo hand in tho tro depertmente without which no gorornment can rork. Horever, if it rere cortein thet the councll really controllod all the businese rhich came boloro it, ro ohould hero to modily conelderably our estimato of Cromsoll's supromacy. Thoro cannot be any doubt that ho rao responolble to the king, and it can be (and has been) argued that llenry did not Eiro him ouch abeolute Ireodors as Holsoy had onjoyed; ${ }^{2}$ it way bo addod that Cromroll does not oeow to hato ranted so much but was almayo careful to ehor himoelf the king's sorrant. ${ }^{2}$ Mao he also tho

1. E.E., A.F.Pollard; Henry VIII, p.350.

2. Cf., O.E., Cranser'o lotter to Henry after Crowroll's arroot (L.P. 28.770$)$. 
oortant of the council? To have ooon that ho did not doprivo It of the part it played in affalro aftor iiolooy'n fall; ro must nor soo rhothor ho allorod himoolf to bo gorornod by it or vhothor ho govornod it himoolf.

Hio contemporaries conoldorod Cromoll to bo tho chlos of the council, a titlo actualiy once beetorod on his by ono of his corrospondents. ${ }^{1}$ Somo lottoro about tho victualling of Calais shor that 88 oarly as Docomber 1533 it vas Cromoll who ras expected to echioro rocults, ovon though it rao offlcially pretonded that mattoro roro doolt wibh by tho king and counc11. 2 Then tho wayor of Ryo nont tro quarrolling partioo to the council he informod lord Rochoford, tho rardon of tho Cinaue Porte; Rochelord'o fathor, tho oarl of Niltahlro, oponed the lotter in bio oon's absonco and shorod it to tho attormey-general who advisod sonding tho partioo to Cromoll. 3 In like manner, in 1539 , a werchant who brought oomo intoronting nowo from abroad and told tho council was sont on to 800 Cromme11.4 A lottor Irom lorfolk and tho council could rooult in a reply to Cromell.5 Man the oarl of Southarpton camo to court for instructions beforo loering on comboolon for Calaio, he wrote to Cromell aoking him to be thero with tho roat of

1. P.R.O.E 36/122, 1.63 (L.P. $211 . I .685$ ), addroosod to tho "[ul oot Torshyffull lordo of tho provo oollo \& cholfo of tho kyngos consell".

2. I. P. Vil:4-6.

4. I.P. XIV.I.718.
3. LeP. V111.776.

5. L.F. V111.389. 
of the council oo that ho might bo doopatchod quickly. 1 A roport could bo addrosood to crowroll and othoro of tho counc11.2

Forelgn offetro might bo dlocusood in council, but, as wo have alroady seon, it was Cromroll who wattorod, and tho important discussiono rere fith his alono. Whon the odmiral of France arrirod on a opocial ombasoy in 1534, no momber of tho council was concorned except cromell.3 cromoll could organise tho fay in which tho councll would rocolro thols information Irov ambassadora; on ono occasion in 1536 ho told Chapuye to opoak with the king at longth aftor dinnor, and on leaving him to soe the council and oxplain hio charge to thom "agreosbly to thoir cuator".4 Tho council, it rould ooom, had eotablished a customary right to information, but wo aro ellowed to understand that Cromoll wao doing no more than bow to precedent. Ho did not wish to antagoniso tho councll by ignoring it, but ho knor and inolotod thot oorious busineso shoula be transactod in tho cbnversationo with the king and himself. In council ho rould often do woot of tho talking, 5 and ambassadors might moot the councll so80mbled at his houoo. 6 As 1ato 80 April 1540, whon tho battlo for tho control of tho council nas well under ray, sadier comounlcatad to Crowoll

1. L.P. IIV.I.596.

3. I.P. $\nabla i 1.1482$.

G. L.P. xI11.I.623,855,909.
2. L.P. 28.32 .

4. L.P. X.699.

6. L.P. XIV.I.926. 
tho king'g ordero, ao a mattor of courso, that Cromwoll wao to arrango some buginese together with tho council.1 Ho wao otill ito "cholfo". 2

Altogether, it ooome that Cromoll was ofton caroful to 8agociate tho councll with himgolf. In roporto to tho king be etresood the lact that he had not boon acting on hlo orm, 3 and lettere conveying ordore or inotructiono rore lreouently olgned by hitw and a for counclilora. 4 The councll of Calalo went go Lar as to opoak of Cromell'o lettor olgned by tho council, 5 and the description is probably accurate. The appearance of an active and gorerning council rao maintainod; but all wen kner who tho real ruler 880 under tho kfag.

Even rhen riting on hio own Cromell rould often protond to be merely communceting orders recolvod lrom king and counc11. The king, he rrote to the univeralty of oxford in 1534, mas informed of their miadeode againgt tho torm, and ho had

1. L.P. 27.468 .

2. The internal trablog in tho council had led ono oboervor as early 88 June 1539 to doubt tho usefulnoss of appoals to the king and Crompell only. Huseo wroto to Lord Liolo: "And whor your lordahlpD wrytothe that yf you wyzt como over you rold ohero tho kyngeo grace and wy lordo privy oealle that thing rherby the tome sholde eror. be the better, yn wy pore opyno on it oholde bo good that jour lordshipp ol gnelyo tho kyng of 1 t and tho councoll whull QII tho lordes ar hore." (P.R.0. 8P 3/5, I.687; L.P. XIV.I. 1144 ).

3. L.P. X17.I.516,538.

4.: L.P. XII.I.639,677,1271; II.275; I17.I.610.

5. $\overline{\mathrm{Li}} \cdot \mathrm{xII} \cdot \mathrm{I} \cdot 560$. 
beon ordered to bid thom reatoro all poroono thoy had diopooseseed. Ho added that tho council had daterminod to maks a Iinal award botween tomand form. A lottor fros tho commooary of tho uniperolty to Fitzwliliam, hisools a loading councillor, ohors that when ho and tho wayor caro boforo tho council thoy actually oam only cromoll and tho lord chancollori ${ }^{1}$ tho council which wade tho Iinal amard was in elfoct Cromoll himgelf. It ras Cromell mho askod the blohop of Ely to attend the council in the folloring tord is hio hoblth pormittod, rho informed tho sherlff of Yorkshire of a council docision to hold an inquioition poot mortem, who roportod to Chapuys in the nawo of tho king and tho councli, mho aokod tho oarl of Fatland to oxamino cortain friars and roport to "tho kingos bighnes or his counooilon, who gare instructiono to firlothooley, then on ambsey in the lov countries, by order of "his highnes by thessent of his hole Counsalin.2 Ho wroto lottoro of oumons to appear beforo tho counc1l, 3 and won poro eften told to appear before him and tho council, information of ouch orders boing given in lotterg addrosgod to Cromoll poroonally, a Lact rhich propides further eridonce of tho opocial position ho occupiod in relation to the council. 4 In ono of tho tro ourviring lottors of his to tho council, viltion in october

1. L.P. Vi1.618,903.

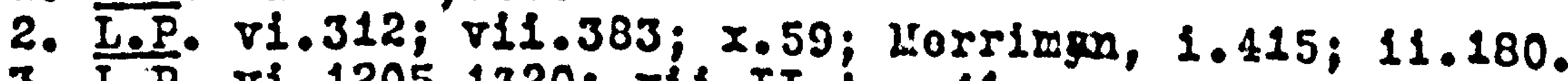

3. L.P. $\nabla 1.1205,1320 ;$;1..I.App.41.

4. L.P. $\nabla 11.1590 ; \nabla i 11.457,515,727$. 
1534 whon ho had otayod bohind in London, ho gavo inotructiono for the further examination of a ouppoood traitor and aokod for the findingo to be sent to him. 1

other people troatod him as tho hold of tho counoll awd appoalod to him if they rantod to socure or provont councll action. The mayor of York aoked thot oulto mado by oomo private persons to the king'o councll be otayed unt1l ho and his brethren could attend; the ambassador 1 ith tho omporor oncloogd a supplication which Cromoll wag to shor to tho counc11, aftermards doing as ho thought Iit; Sir John Bassoll asked him to summon before tho council somo criminals againgt whom the local megiotrater rere porerlese; a man oubpoonaed to appear before the lord chancellor and tho councli in tho otar chamber excusod himself to Crompell on a plea of 111bealth; another reminded him of his promise to bring his oult to the consideration of tho council; a lettor from Antrorp roquestod that Cromell ohor cortain parto of it to tho council; when Calais informed Cromell that the appointment of certain officialo belonged to the bailly and Ireomon of tho town, the order was confirmed by the king and council to whow Crownell mast here passed on tho information - in fact, Liolo opoke of cortifying the king by letters to tho lord privy ooel; in a diepute orer the omerohip of some confiscatod property Crom-

1. L.P. Vij.1271. Tho othor in L.P. 20.910, writton from tho To:zor after his arrest. 
roll rag appoalod to far a cortillcato erom tho councll. 1 There 10 an intoreating lottor erom Jicholao Shaxton, blobop of Sallobury, tho in June 1538 Froto to Crowroll for 80010tance againgt tho othor lordo of tho council. 2 Hlo friond, tho king's almonor, had opokon with tho king about shaston'n coming to court, tho roason for hio aboonco haring boon a caro of plegue in hio housohold. Tho king told hla to haro 3harton come after tho ond of parliamont; in tho woantiwo ho ras to attond parliament, "excopt I ror. Lorbodon by tho comsoll. And therfor, wy good lord, it sball nowo bo oponly known that I am forbedon to come at $\mathrm{y}^{\theta}$ parlicmont by tho comsoll, oxcopt that by this occasion thoy bo contont that I come thythor now agayn... I besocho your lordahip to bo $A$ mean to tho othor lordes of the liyages nost honorable comoell that I way knorre thir pleasureo horin." Thero to mach 1030 suggoetion boro. than usual that Cromoll could do rhat ho likod with tho counc1l, though ho 788 otili considerod tho right wan to modiato botroen council and supplicent. shaxton 780 of hio party, a Lact which detracto Irom the valuo of tho oridonco for hio pooition. It will bo noll to romombor thio furthor pointor to a change in tho relativo positiono of Cromboll and tho councll in 1539 .

1. L.P. Vi.904; Vi1.124,1034,1232; Vi1i.863; 1x.105; xi11.II. 161; $2 \pi \cdot 426$.

2. P.R.O. SP 1/152, I.102 (L.P. Xit.I.1157). 
lierortholoss, the point phich mattoro to that tho activo council of Cromell's timo rao vory wuch undor tho control of tho king's chlol winloter. He ras 1 to loador, 1to unoficlal hoad, evon at the time of the pilgrimage of graco whon, ao to have seon, thero was a tomporary tendoncy for him to rotiro into the background. One of tho messonsero to the robolo ras examined by thom as to whom ho had ooon about the klng, and phethor Crowrell ras otill of tho council. Ho ropllod that ho had ooen llorfolk, Oxford, Susgox, Fitzillllam, Paulot, and kingeton, but that Cromsell had not beon to court for oomo time before be loft. ${ }^{1}$ The man ras probably talking for hio I1fo, but wo knor that Crowroll was indood aboont from tho court for quite some time in tho last wonths of 1536. Horovor, thio goems to have been largely a neasure of prudence in fiom of the robelo' spocific complainto againot cromell, ${ }^{2}$ and tho real balance of porrar betroon Crompoll and the councll mas probably iftllo affectod. At any rato, in Norember 1536 Aske rroto to Darcy that Cromoll was, ot1ll or again, tho "only ruler" about tho zing, 3 and eren at tho holght of tho criolo llonry askod cromirall to hold the enroyo from tho north until tho tro of them, together with the council, had distussod tho aattor. 4 Cortainly until 1539 Crompell 583 undioputodly the keng'o chiol

1. L.P. $x i 1 . I .1013$. 3. Ibid. 1128.
2. L.P. $21.585,860$.

4. Ibid. 985-6. 
councillor, and tho councll did 1 to rorls undor hio diroction. He showed no dosiro to do fithout a counc1l - in thio ao in othor things ho way havo loarnod from Rolooy' unfortunato axample - but rorkod through a council mhich ho dominatod. Apart erom tho various rayo in rich hio loadorohip of tho council showod to outgldoro, Crowroll controllod ito buelness and agonda. Evidonco of this ourtiros in a for momoranda and recordo of mootings. Cromell notod dorm, for instanco, that he rould have to "adrertioo the lords of the councli that no more ollorance lo given to purvoyorg shon riding out than elreponce a day for him and and his horco, which is sufficiont... Thie in 1533; two joars later tho tono of his notoo 1mplleg a change in the rolationo botroen his and tho councli: "That tho porfoction of the larro rhich hath boen this two yoaro thoroughly and indifforently oxaminod by grast numbero of oago clerks of the realm may not only bo publighod to tho king's council...betweon this and next eesolon, but aloo that all thoso lawo which bhall bo thought expedient for tho good ordor of the English church may paso by let of Parliamont, and to bo used as tho King's lavo for oror within thio roalm." 2 In tho Iirst caso ho had but advioed tho council on a dotall of administration, whlle by 1535 ho ouporfisod what busineos should como bofore it and ras confidently anticipating ito dociolono.

1. I.P. V1.1609. 2. I.P. 1x.725. 
Anothor of of of hor carelul cromell rao of the councll'o buoineos is that apparontly ho kopt a privato rocord of counc12 procoedinga. On the back of a lettor datod 28 llay 1533 he wrote a list of netters under tho hoading "norembrancyo to be put into my boxe for thingeo dono in the Comsaylo". 1 Thio note ralses the queotion whother an offlcial reclotor ouch ao the "Ellesmere oxtracto" are claimod to roprosent vao cont1nued under Cromell, or whother it 700 the aboonco of ouch as regiater that induced cromrell to kaop a privato rocord.

The mast obrious ray of controlling the council ras to prepare ito agenda in dotall. For notos of that kind ourvivo, but those that do are enough to prove that crowrell Irequontly came to the council board with a numbor of pointo ohich ho rantod discussed. From rhat ro knor of hio gonoral attitudo, his wido and dotailed control of all aspocto of tho adminiotration, it sooms logitimato to infor that the for known casoo of such a preparod agenda reprosont a reasonably common practhat tice, and tho council rould usually find $1 \pm 80$ lf dobatlag matters submitted by Crorstell. In 1537, a l18t of busineos to be troated in council in Mriothooloy's hand showo ito provenence; Triothesley also wroto out a liot of the council's deciolons on that particular day. ${ }^{2}$ It therofore oeomo that the

1. P. R. 0. SP. $1 / 76,1.137$ (L.P. V1.551).

2. L.P. Xi1.I.815-6. Sim. L.P. Xi1.II.177. Tho 110t in LeP. xi1. I. 1091 is doscribod 83 council businoso in tho calonder, but it $800 \mathrm{mo}$ woro likely that tho notoo roro moant for Croamell's eyo only (c1. abore, p.280, n.1). 
council's clorical rork rao aloo handlod by Crowroll'o orm secretarial organiastion. Thore 10 a noto of "cortain rattoro to bo lald boloro tho council" in Soptombor 1539 amons the Hatflold USS, but tho calondar doos not, unfortunatoly, givo any indication of tho buglnoos concornod or from whom the note omanated. 1

By far tho beot examplo of tho mannor in rhich tho council's busineso ras preparod and doopatchod is to bo found in a numbor of paporo concornod rith a councll wooting of 2 Docomber 1533. It $\nabla 111$ bo adpioablo to go in dotall through the stagos boforo, during, and aftor tho mooting. Tho caso 10 exceptional in being 80 roll documontod, but thoro is no rosson to think that it io roally unique. Aftor all, tho counckl's agonds mast always have undorgono somo such proparation, poirhapo usually in 1080 formal dotail, and wo way 7011 boliovo that thio mooting providoo us rish a gratifyingly full vien of tho way in which Cromwoli uood tho council.

The lirst thing that happoned was that a lohs liot was drairn up by a clork, giving thoso polnto: 2

1. All biahops to bo examinod individually whothor they could Iind any oupport in "tho law of god" for oupposing that the popo had any woro authority in England than any othor

1. H.H.C., Hat1101d USS, 1.11.

2. P.R: SP 1/80, II.171-5 (L.P. VI.1487[3]). Tho clork in question ras alwoot cortainly Briothosloy, to judgo from tho vriting. 
Lorelgn blohop.

2. Tho blohops to soo to it that oormons woro proachod doclaring tho authority of tho popo to bo roid and uourpod.

3. S1milar oormone to be proachod ovory Sunday at tho Cross of 8t. Paul'o, tho biohop of London boing mado rooponolble.

4. Ald bishopo to bo ololiarly inotructod.

5. Tho noblos to ingtruct thotr housoholdo in 11 ko mannor.

6. The ohoroo and frontiors of tho roalm to bo fortiflod.

7. "Som truatlo porsons" to bo oent to Iroland, "to 800 that Domynyon ostablioshod, and also to drem and adhore towardes the king asmany of tho groto Iryooho Robollos as 10 posolblen.

8. To reform the administration of Bales 80 that poaco may bo preservod and justieo dono.

9. Tho navy to bo ororhaulod.

10. "Ordynaunces and munycyono of parre" to bo surveyod and ropairod.

11. To surrey and comploto storos of borro, arrors, cuno, gunporder, etc.

12. To oond ambasoadoro to various parto of Gormany.

13. Ambagaadora to the c1tios of tho Hanso.

14. The oamo to Furomberg and Augoburg.

15. Tho four ordors of Irlarg to proach as aforooasd. 
16. The Iriarg obsorvant to do Ilkorioo.

17. The mayor, aldermen, and common council of london, ao rell as the corporationo of othor torng, to inotruot tholr households againat the popo.

18. Afi hoads of rollglous houros to inotruct thoir convents in the saso ray.

19. Evory biohop to instruct ovory prioot in hio diocoso in tho ocme nannor.

20. "To rowombor tho morchauntoo oduonturore hauntyng tho domynyone of Braband, and to otayo thom."

21. To discuss tho housohold ostablighmont of "tho prynces Doragierg" (Ratharino of Aracon).

22. To do the oamo for "Ey Lady pryncoon (Elizaboth).

It is an improsolvo list, but its vory longth negeooto that in wany c8808 tho council rould bo woroly aokod to ondorse something, or rould delogate tho rorli to oomo individual miniotor. The first draft ras rovioed, and tho oocond araft is in a hand which io Iamiliar from many Cromollian drafto, Lor instanco parliamentary b1118. 1 It 10 probably tho band of a aignot clerk, and as Cromell, though not yot oocrotary, res at the time doputising for Gardinor, ${ }^{2}$ tho omploytiont of $e$ olgnot clork rould link his oith tho draft. Thero 18, hororor,

1. P.R.0. SP 6/3, art.21 (I.P. Vi.1487[2]).

2. Above, p.102. 
moro ovidence than this doubtful point for tho fact that ho man concerned at any reto in tho oocond otago of tho proparationo Lor this important council wooting.

Tho not draft re-arrangod tho 1 tom of tho agonda in a moro logical order, beinging pointo 15-17 formard to bo jolnod on to point 4, and putting pointo 18 and 19 to 80 to follor point 5. Tho agonda 780 thoroforo now oot out in grounod toplco: propaganda at howe to oproad the ner thoory of tho papal poaltion in England, in tho pulpit $(1-4,15-17)$ and in privato $(5,18$, 19); the getting in ordor of the roalm (6-11); ombasoloo to Gerwany (12-11); and soso indiridual pointo (20-22). Tro nor Iteme rero added: (23) tho opiritual and tomporal pooro mere to rrite a lotter to tho pope, and (24) oplos rero to bo oont into scotland.

Crovroll mont ovor thio draft, corrocting and adding to 1to various hoado in hio noot charactoriotic mannor, and thoso correctiong noro obbodiod in tho next otago of tho drafto. The blohop rero to mako up thoir mindo not only about tho popo's authority in England but alno about bio pooltion rolat180 to tho gonoral council of tho church, a point also to bo includod in thoir proaching. Tho popo, it had originally boon put, had no woro authority in England than any othor forolen bishop; Cromtoll clinchod thio point by adding "rhich 10 nothing at all". Tho Iriaro' ordoro roro not only to bo nogo- 
tlated with, but roro aloo to rocolvo "O ntrayt Comandomant" to sot forth tho now 1doad. If tho oboorvant erlaro rould not agreo to tho order, thoy ahould "bo otayod and not suffryd to pracho in No placo of tho Roalwo". Tho blahopo roro not to "toche" but to "make spocyail Comandoronttos" to tholr diocosan clergy "to procho and doclare to thoyr parochano in lykeryoo". Polnto 6 and 7 moro olaboratod with additional dotall. The envoyo to tho Gorman princos and to tho Hanoo vere to bo opociolly inotructed to "Inoercho of what Inclynacyon tho sayd prymcos \& potenttattoo bo of". Not only Katharino's housohold but Lary'o aloo was to bo oottlod. Whore, in point 23, tho scribo had opokon of "tho Popo", Crommoll put "busahope" (loaving out 'of Rowo"), and ototod tho oubjoct of the lottor rhich had provioualy boon loft undolinod ndocleryng tho rronge, Inluryer, and roupacyono' 1 royd agoynot tho kyngoo highnos \& this Roglmon. Thoso and othor corroctions ahor hor freely and fully Cromroll controllod tho councll'o agenda. Ho made wany of tho pointo auch moro dofinito and detailed, proscribed tho lines on mbich tho noblos' lottor wao to be conceived, and genorally oharponod tho tono of tho dreft, by oll rich moans ho ooverely curtallod tho councli's liborty of action.

From thio draft tho actual agonda mos drarn up.2 It 10

1. Sic.

2. B.य. Cloop.E.V1, 11.325-8 (L,P. V1.1487[1]). 
In Ralph Sadler's hand, and in 1533 sadlor Fao ot1ll no moro than Cromwoll'o confidontial clork. Tho finiohod product, therefore, came from Cromoll's offlco, ovon if nono of tho oarlier drafts can definitoly be provod to havo done oo. Thoro are sobo interesting dfferenco from tho socond draft, particularly three ner items: proclamationo pore to bo publinhod containing tho thole act of appoalo, ${ }^{1}$ and tho king's provocation and appellation from Rome to the gonoral council woro of allarly to be exhibited throughout the roals and abroad, espocially in Flandors. ${ }^{2}$ Pointo 5-11 and 17 roro baltted; thooo concornod the setting in order of the country'o dofencos and depondoncios, and tho propaganda to be opread in privato housoholdo. It may bo eupposod that the formor task ras in any 8880 being attondod to by the king's minletere and noodod no furthor discuesion in council, 3 while it way roll havo boon thought too dangorous to prese tho socond point. A council rhich 780 by no moanc united on the king's ecclesiastical policy alght not take kindly to a suggestion that its wombers ohould adrocate this pollcy in tho privacy of their homes, and any attewpt to onforce such a weaoure on all the nobility and wunlcipal officials in England could only end in failure or revolt. Tho idea nas theroforo dropped, to be replaced by tho more usual and practicable

1. 24 Henry VIII c.12.

2. Pointe 9-11 in tho numbering in the Ls.

3. All these it ems of the agonda roro recolving Cromoll's attontion in April 1534 (L.P. V11.420). 
method of propaganda by proclamationo affixod to church dooro. Fo cannot oay for cortain whothor Crompoll wao bohind those further changoo, but ro most otroga again tho fact that the agonde was writton out in his offico. It may bo concluded that if ho pas not alono roaponolblo for 1 to tormo and heade he must at any rato havo had a conoldorablo oay in thom. The copy of the rgende ahich ro posgoso has notos in hlo hand in the margin; the notes rore made aftor the council mootine, and it ia therefore cloar that bo kopt tho copy phon tho council rose. It doos not ooom likely that woro than ono copy was dram up, and it is wuch woro probablo that Crozroll ront to the council with this papor in hand and road it to tho mooting:point by point. Tho altornativo, that onough coploo roro mado to give one to oach councillor, way bo disalosed ao intringically moat improbablo. Soseone mast havo road tho agonda to the council, and ororytiling pointo to cromroll.

If our reconstruction is corroct, 80 mat inagine Cromell not only proparing tho council's buainoos but aloo oubulting It to the board. As later teotiwony ohorro, that ras the ray in which Tudor secretariod of otate actod in mootings of tho prify council. In hio account of prity council procoduro, written in tho early yoaro of the oevonteonth contury, sir Julius Caesar deklared that ono of the secrotarios had alrajo attondod the nootinge; ho Fould otand at the uppor ond of tho tablo, put 
Lormard tho buglnoos to bo dlocuoood, and nok tho councli'n opinion. ${ }^{2}$ The oocrotary'o control of counc1l bualnood 100100 brought out in the ordors for the privy councll drarn up in 1550: ho was to bring all lottoro to tho council, to chock the regieter and present it for ofgnaturo, and to tako ohnreo of all vritings ordorod bif tho council. ${ }^{2}$ It $w 80$ Eromiroll who created the principal socrotaryship of zudor timoo, and though he ras not yot socrotary in 1533 ho ras acting ao ono. In vior of contomporary: oridonco and lator practico it sooms moot reasonable to suppose him taking thio particular copy of tho agenda, probably tho only copy eror mado, to the counsil yooting, roading it out thoro and anking the councli's mind on oach succossivo point.

$\triangle$ note of tho council's docisions at thio mooting of.2 Docenber 1533 aloo surpives. It is hoadod "Acta in Consilio domini Regis $1 j^{\text {do }}$ Decerbrio", is in a clorical ocript ith additiono by lord chancollor Audeloy (ho wroto, for inotance, the last throo paragraphs), and bearo ono corroction in Cronrroll's hend. ${ }^{3}$ Audeloy had put the "castol of horfl" as tho place whore the princess bllzaboth wao to haro hor housohold, and Gromoll substitutod "Hatfolda". Ihlo lo a vinor polnt, but it proveo that cromell ront oror the rocord and chockod ito

1. B.I. Add.AS 34324, 1.239.

2. B.L. Egerton US 2603, If.33-4.

3. B.H. ClOOD.E.จ1, 1.329 (L.P. จ1.1486). 
accuracy.

The momorandurs 110 to tho pointo no thoy noro numborod in tho agenda itoolf, but in order to noid confunion wo shall horo koop our om numoration. Point 1 rao roforrod to $3 \mathrm{amp}-$ son, doan of the chapel, and Foxe, the king'n almoner, "s othor doctours", who wero to consult tho authorition and roport to the council by the ond of the rook. Naturally, "as onto tho oother Vifl Articios, dopending rpon tho oniod flrot, tho Counsall will bo advised thorof ontill tho rotourne of tho gaied anstrer." Then thoy rocolvod thoir anotor Cromoll ran after all entrusted if th the execution of tho necosoary otopo, as his woworande of January 1534 ohor. ${ }^{2}$ The throo propooalo Lor propaganda by proclamation rore comsttod to Cromioll and Audeley "to put in exocutiag fith all epode". 3 so for point 23, the lotter to the pope, Fozo ras ordorod to draft thio "according to the purport thorof", that io, according to the outlino added by Croprioll in tho oocond draft; tho councll miohod, honevor, to see firot tro lottero proviously oont to Romo, ono under Edrard I and anothor rocontly. The opios to 3cotland rore to be seon to by llorfolk and Cromtell, and as for tho ombassios to Qermany, the council advioed that tho king of Franco

1. Correctod Lrom "1x". 2. L.P. $\nabla 11.43(2)$.

3. Tho ocribo had put crowroll only, adding in a soparato phraso which probably reprosonts an aftorthought on tho council'o part, "rith the lordo Chauncellour with hym". Audoloy, not liking this, had crosood out the phraso and intorlinoatod "wy lord chencellour \&" boforo "ur cromorroli". 
bo Ilret inforrod by woano of a lottor sont to tho English ambassador rosident. Tho laot throo points, tho housoholdo of Katharine, Wary, and Elszaboth, wero docldod by tho king Tho was posoibly prosent at the meoting. Audoloy woroly notod that Honry had poroonally ordorod cortaln councliloro to attond to the businoso, "acordyng to oucho Inotrucciona ao ohalbe dovised for the samo". Honry way havo sald so at tho counc1l boord, or he may have bont rord frough (rouroll?); at any rato, tho mattor ras taken out of tho counc1l's handa. The lact that it camo bolore tho council at all ouggosto that Henry had little to do with tho draring up of the agonda, a guggestion which strongthons the oosumption of Cromell'd 0010 parentago.

Altogother the council had not dono mach, considoring what a tromendous arount rao put beforo it. It had tonderod advice, of secondary laportanco, on ono polnt. A numbor of nattors it had lelt to ito noot prominont momboro, and horo again to way notice that Crombell was oron thon, four months beforo his socrotaryship, quito the most conopicuous. Tho roally sorlous business on which it was to docido - tho att1tude to bo adoptod torardo tho church and any posolblo obotruction Irom that quartor - it had sholvod rith tho fooblo protonco that "tho doctourg" rould firat havo to diocoror tho facta of a controvoroy which had boon docidod ofght montho oarlior with 
the passing of tho act againat appoalo to Romo. Tho councli'o procrastination may havo boon duo olmply to inolfleloney or, noro dooply, to tacit oppooition; in any cano, it had not ohom itooll to bo an activo gororning body.

Nor ras that all. Tho notos which Cromroll mado in tho margin of tho agonda rovoal a littlo moro of tho viay in which tho gorernwont rag really carriod on. Tho lordo of tho counc1l had at least ohom a doolro to haro tho lottor viltton to the popo, but eren in this thoy hed boon promaturo. Cromoll noted that it 780 "not yot dono no can relbo dono boforo tho parlyament", for of couroo tho prooonco of all tho opiritual and tomporal poors was roquirod for olenaturo. Polnt 24 had boon loft to Cromell and liorfolk, and it 780 Cromoll who put dom tho dotalle of rhat had to bo dono: "for to Bond lottoros to my lordo dacro, wy lordo of llorthumborland, and Byr Thoma clyfford," the rardens of tho northern marchoo. Tho counc1l, and possibly llorfolk too, loft to him tho actual adminiotration of cortain otops rich had boon put boforo it in roady form, and rhich it had merely ondoroed. Tho enroyo to Gerwany, on tho othor hand, voro not to bo sont until a highor authority hed spokon; that mattor atood ein tho kyngos arbytromont". Hororor, a Ior rooks lator Cromell ras noting dorm that ho would have to derioo tho rarious dotallo of thoso ombroolos who was to go and what hio inotructiono woro to bo; again wo 
Boo who did tho actual rork of govornmont. 1 Point 19 10 annotatod "this is all rodo doon"; as tho point rao apparontly not discussod in council Cromstoll'n noto may haro boon mado boforo the moeting. Againgt tho laot pointo Cromrolil notod that the noceosary ordorg had boon 13guod.

If we have gone at considerablo longth into thin council meotine of 2 Decombor 1533, it hao boen bocaugo nothing 11ko the same detall can bo found for any other mooting during Cromell's supromacy. The four documonto arallablo haro onabled us to conclude that Cromoll suporvisod in dotall tho proparation of buolnoso for tho council's considoration, that even at the start of his caroor he would bo ontrusted by tho council with wuch of tho administrativo rork discusaod, and that he could afterrardo act quito on hio orn, oxcopt for hio dependence on the king. To have aloo given roasonn for bolioring that it ras he rho actually subalttod tho council's businose and thereby practically conductod ita mootingo. Hor evor, than is a conjocture and it does not mettor rory much Thother it be acceptod or not. Cromsoll's control of the council in 1533 io manifost; wo bnori that tho council continued to woet and act throughout Cromoll's caroor, and if such a measure of control can be protod at tho outbot it may

1. L.P. $\nabla 11.48(1)$. 
bo asoursod to havo boon at lonot ao comploto in lator yoaro of greator porer.

It may be rell to sumariso tho argumont as it otando at this point. Thon Cromsell camo to porror ho found a council which had rocovored from 1 to ocllpoo undor polooy, a councll of comparatively for momboro which mot ofton and handed under the king - the buainoso of tho otate. Cromoll made no oseontial chango in thio, oxcopt that ho put himoolf at tho hoad of the council, botroon it and tho king, 80 as to rulo and control it rather than do fithout it. Tho counc1l of Crommell's time was an actiro body, busy about many copocto of the government, though in fact it uoually did nothing oxcopt support the policy and mosouros put forrard by tho king and Cramoll.

There is something to shor that gorormont by council ras ono of Cromeli'o chiol conotitutional 1deao. Ho practico in diligontly kooping eliro an actire council contraotod otrongiy with that of Folooy; more than thio, it was undor his that concillar bodies taltipliod and asoumod a nor laportanco with tho ostablishmant of a council in tho poot and tho comploto ororhauling of those in tho llorth and tho marchos of Ralos. Te nust not go:Into the mattor in detail, for a diocusolon of thoso branch councilo rould tako uo too far affold. Buffico it to say that officiently oreanisod councilo undor actiro 
prosidents, staffed by a mixturo of momboro of tho contral council, local gentlomon, and trainod gorornment offlclalo, and with permanont clerks of thois om, woro Cromoll'o anorior to the sorlous adminlotrativo problomo oot by the outlying parts of the roalm. 1 Thore 10 also tho woll-known noto in his remembrances: "To appoint tho noot asourod and oubotantial gentlemen in every ohiro to bo ororn of tho king's Counc1l...", apparently rith the intention of creating a notrork of king'o councillors for policy dutios.2 Though thlo 10 a difforont 1 doa from the centrallsation of gorornont in tho bando of omall counc1ls it shoris a girllar rogard for gorornsont by thooo orrorn of the council. Cromell's thought had taken him boyond tho oomerhat crude concoption of a lonely and poroonal aocondancy, and hio practice torardo both tho contral council and 1 to branches in the marches of England shors that ho riohed to boce bio adminiotration on otall and tightly orgeniood councilo. Lt tho ocro tife, thore wes no quootion of ourrondoring hlo roal power. The brench councilo rero kopt under otrict ouperviolon, and tho central body 500 elfayo to bo diroctod by bita.

1. For thoso councile c1.: C.A.J.Skool, "Tho Councll of tho Niost",

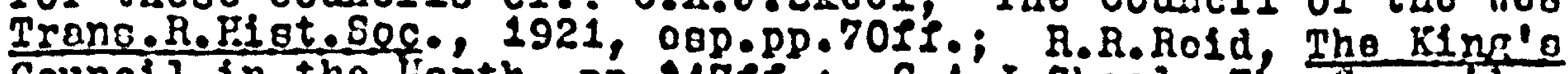
Council in the liorth, pp.247ff.; C.4.J.Ekeol, The Council In the Jarchon of Fileg, pp.651\%. For Crommoli's control cl. hio corrospondonco rith theoe counclio, nproad ovor L, ,, and noteo in his cemoranda for the ostablishmont of a council in tho north and tho ordorine of tho rioot earchoo (L,P. III.I. 1315).

2. L.P. V11.420. 
IV. The Rige of tho Privy Council.

Whon tho council mot on 10 Auguet 1540 to appoint a clork and provide for tho kooping of $n$ rogiotor, ${ }^{1}$ the prify council had definitely arrived. It wao not nor thon, for tho ontry in the record otates clearly thot "an ordro noo takon and dotermined by hio Lalosto by thadvice of his Highnoo Pryvoy Counsalll those nelies horeafter onsuo". That rea nor was tho content of that order, not the exiatonco of tho prify council, fully organised and clearly distingulohod from tho council in genoral and the othor bodies rhich had branched off from it. It rould not in any c8oo bo crodiblo that tho privy councll should havo burat upon the rorld fully grom, fithout any proIiwinary developwent, and ito beginningo havo in lact boon tracod back to at loast tho last montho of $1537 .^{2}$ A body which can only bo doscribed as tho erivy council oxiotod boloro Pagot's appointwent as clork, and wo mat now concorn ouroolvoo with inveotigating tho adolesconco of thio distinct and soparato innor council. The difficulty is that there is littlo agreemont on what constitutes the privy council. Thoro id no doubt that tho crom had habitually called upon a omaller numbor of coloctod councillore for advico on mattoro of pollcy, and that tho wholo body of men swom of the council did not form that council which

1. Nicolas, A.P.C., Vi1.3.

2. A.F.Pollard, in E.H.R., $x \times 28 i 11(1923)$, pp.431. 
wot ifth oowo regulerity for tho carrying on of tho govornment. What, thon, is tho differanco botroon a owall innor ring of tho council, such as wo sar at rork in 1532, and tho rully llodgod priry council? It has boen uaual to arold tho difflculty by reaerving the nor nawe to the orjanloation rhlch omorgod into the light of doaumonted hiotory in 1540, but that, as wo havo soen, ignores tho fact that tho priry council moot cortainly existed beforo that date. For an undorstanding of cromoll's attitudo to tho council an inrostigation of the origino of the privg council is quito essontial. It carnot havo taken ito rise later than the timo of his oupromary.

Firot then, vibat is it that difforentiates tho privy council from tho informal innor group of counclilors which wot bo neariy as old as the council 1toolf? Profosoor Pollard hao given it ao his opinion that "tho koy to tho diotinction botreen the wodioral council and tho incipiont prify council of Tudor times is the distinction botroen a council which wot only at roatminster during ters, and a council rhich not all tho year round and aat with tho king whorovor ho wight bo". 1 Th10, horever, provides no clue th tho diotinction botrioon tho incipfent and the cotabllobod privy council, botrocn the informal "inner ring" of councillors mootine rith tho king and tho fully doreloped institution. The truth ooomo to bo that tho dif-

i. L.F.Follard, Molooy, p.111. 
forenco 1108 in ono rord - organioation, e oomowhat intanglblo factor in the aboonco of oove dofinlto ordor ontabliohing tho thing organiged. Horrovor, the fact of organlabtion is bound to shor in the result, and perhape ro can find nomo pointo which will holp to track it down.

Fo nubalt that thoro aro six diotinot charactoriatico which we rust find in tho council beforo wo can call it "prify". It mast attend on the leing phorovor ho g000, it mat noot Iroquently or nearly orory day, it must bo lint tod in poroonnel, Ito cemborship mot bo Ilxed, its roris wast bo on tho dotalls of adoiniatratiro businoss as pell as on pollcy, and 1 t mast hevo at loast ono olork opocially and pormanontly apnointed. To the leot point wo wight add tho kooping of a rogloter, but It io cuite poselble to imagine a privy council without rocords and eren possibly without a clork. Tho history of tho cabinet should wake uo rary boforo re make tho kooping of rocords an essentigl point in tho organisation of the privy council, and throughout tho olxteonth contury thoro roro many meotings from which the clork ras excluded and for which no entry therofore ourvives in the roglotoro. Nor mot the othor ilve ronulroments bo pressod too logically and rigorously. Tho indubitably privy council of Auguat 1540 did not moot overy day, nor did all its membors asoomblo on orory occealon, but mootings rore Ironuent and no councillor attonded who was not in the liot 
of privy councilloro givon at tho bocluning of tho roglotor.

of thoso characterlotica, ono has alroady boon diodunood at longth. Tho rork of tho counc1l undor cromell wao man1sold, onorous, and 1wportant, though admittody it ras dono under Cromell's control. Tho councll was not noerly 00 oogential a part of tho Borernmont as appearancos rould auggoat, but control by one wan wao not incompatible with tho gonulno prify council. Miat wattoro horo is the naturo of tho bualneas transacted and not the reallty of porar. In thlo ronpect the council of the interval betroon rolooy and cromtell Iulfilled the conditiono which way be laid dorn for the prity council, and cromeli's arrifal mado no difforonco in that.

To turn to tho quostion of attondanco on tho bing. Tho Elthas Ordinances of 1526 had propidod for a poranant council of tronty members to giro tholr attondanco on tho kefng'n woot royal pergon, but by alloning for the neceobary abooncos of 811 tho woro important officors of 6 tato tho order had roducod this council ilst to a comalt too of ton, thon to a oubcomittoo of four, and finally had in doopals arrangod for tro councilloro alrays to be presont, "oxcopt tho King'o grace Elvo lyconco to any of thom of tho contrary".2 Thooo councilloro foro to

1. In the last threo rooko of suguot 1540 tho prify council wot lourteon timeo a largo gap boing lolt after 1 to inauguration on the 10th. Tho usual attendanco ras ofx councliloro out of a posolblo ninotoen, thourh goron camo fivo timoo and nino

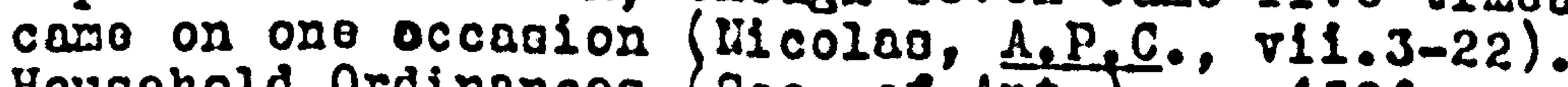

2. Housohold Ordinancos (soc. of Ant.), pp.1591. 
attend every day for the deapatch of bualneos of otate and tho hearing of petitiono. A council attonding on tho king which might congist of tro out of tho logs important councillora rao clearly no privy council, and the hopo oxproosod that if the direction was noll obsorved "tho King's hlghnesoo ohall alrayoo be rell furnished of an honourable preoonco of councelloro about his Grace, as to hio high honour doth apdortoyno" hao the Ilevour of subtlo irony. It mat not bo forgotton, too, that the rord "council" ras Iroquently uood in a colloctivo rather than corporate sonso, woaning a for councllloro rathor than an organised council, a fact for which tho many reforoncos to tho king's learned council provide sufficlont proof. Theso roro the king's legal advisers as a sroup, not by any noans a committoe of the council doaling with legal buoinese. Tho council in attondance on tho king might thoroforo bo olthor a body like the later privy council travoling about with tho king, or 8 number of councillors tho happened to bo at court. In 1526 tro such councilloro rore rockoned oufficient, though it ras hopod to have a largor number usually in attondanco. At any rato, there is no evidenco that tho Eltham Ordinances Fero carried out undor Folooy.1 Fo wuot soo whothor we can find a councll regularly in attondanco during cromoll'o rule. The privy council of 1540 attondod the king's peroon, 1. A.F.Pollard, in E.H.R., $\operatorname{xxrri1(1922),~p.359.~}$ 
for it soomo to havo wet in o difforont placo noarly ovory dey. To wust probably lmagino it travoling in tho morning and wooting in the oftornoon or ovoning, and tho ploturo of the menner in rhich the govornsont of the country rao carriod on is certalnly odd. The ovidonco for rhat happonod in the $1530^{\prime}$ a is naturally, in the absonco of roclatoro, rathor 1000 cloar. During the interval boforo Cromoll'o rloo to portor tho king appoaro ofton to havo oat in counc1l, a fact which implies that tho council at tondod on his regularly. 1 Thon tho papal nuncio ront to court to opoak rith tho king ho ras confronted by tho council ingtead.2 on tho othor hand, in June 1534 tho council ras reported to bo coming to llampton Court, rith tho "gentlomon drolling about London", in order to woot tho ambasaadoro from Lubock. 3 That doos not $100 \mathrm{k} 00$ wach like a council regularly in attondance on tho king. It is true thot the king rould atill attend counc1l nootingo, 4 and that Chapuyo could Iind the council at court, 5 but that doeo not prove that tho council ras alrayo thoro. Thor rould nor aelly do their rork at court, in tho prosonco on or off otago of Henry bimsolf, bat thoy nood not nocoosarily hare follored hit about and way rell hape boen ourimonod for opocial occaolone as in tho case of the Lubeck ambasoadoro. On an earlior

1. L,P. $1 \nabla .6738 ; \nabla .105,216,287,773,1013$.
2. Ib1d. 1633.
4. L, . $\nabla k 11.826,912$.
3. L.P. $\nabla 11.888$.
5. IbId. 189. 
occagion, a Fronch onroy had boon told that no doclal on could bo arrived at becauso tho king har not yot mado up hlat wind and tho council roro disporsod; ${ }^{1}$ ovon if this oxplanntion was only a pretext to corer up nrocrantinntion it could not havo boen mado if it had not atill boon comon onough for tho king to be without his council.

Howorer, there aro indication that thinga bogan to chango about the beginning of 1536, or at any rato $: 0$ bogin to got ovidence for a change of practice about that timc. In April 1536 the council sat orory day at Groonirich, that is at court.2 The ofidence beconos otrongor for tho folloring yoar. In April 1537 the council ras if th tho king at Groenrich, though Cromell was in London and hio coming rao airal tod boloro norrs Irom tho continent ras to bo discusood. 3 Thon the kinf norod Irom Haspton Court to Eohor in Soptorbor 1537, ho dininiohod all his attendante' company and ordored tho lordo of tho council who voro present with hin to inform Cromtioll and sudoloy to do likerise on their coming to court. 4 obviously tho council trevelled with tho icing, though not all 1 to momboro roro necosoarily at court. By oarly october, Cromoll had jolned the king at Eshor where Lord sandos oarr both thom and tho council. 5 In January 1538 tho council roo agnin oftting at aroon-

1. L.P. $\nabla, 375$.

3. I.P. xii.I.1009.

5. Ibid. 802 .
2. L.P. $x .748$.

4. L.P. xi1.II.774. 
Wich, and they roro ntill with tho kind throo $700 \mathrm{~kg}$ lator. Tho following yoar tho king again conforrod with tho lordo of tho council at Naltham whilo Cromroll rao in London. ${ }^{2}$ on tho other hand, it ras otill posolblo for tho king at Mindaor to tell somo of his councilloro to ordor othero to mooomblo in London; this lottor in itrolf, horrover, proven tho conntant attondanco on tho king of at loast a oubotantial part of tho inner council. 3

There may haro boon a council attondant on tho ling, as an organised body, at an oarlior timo; in 1529 a man triod to rotain Cromrell for the drafting of a documont domanded by tho "council attonding tho king", ard a sumons undor tho olgnot of Septeaber 1535 apoke of an appoaranco "bofor ve and our counsail attendant rpon our person, phersoouor so ohal chaunco to be". 4 The firot caso, horovor, doeo not provo tho exietenco of a regular council attendant and nay oron rofor to no woro than a for (legal) counoolloro thon in tho leing's ontourago; the other, on the othor hand, ouggeste that coso regularity had boon achiovod. Hororor, it is caot in official phrogoology and wust thorofore bo troated with nome caution. Tho attondanco of a council on the king was no doubt dosirod but ro cannot be suro that it 700 also socurod, and a sumpono boforo tho counc1l might, as no havo alroady soon, rosult in an intor-

1. L.P. Xi11.I.91,241. 2. L.P. X1V.I.236. 3.L.P. X1V.II.183. 4. $\underline{L}_{\text {, }}$ Add.666; P.R.0. SP 1/96, 11.165-6 (L,P. 1x.369). 
Fion with only ono or two counc1lioro.1 Tho orldonco alloro us only to bo roasonably cortain that thoro wao a councll rogularly attonding tho king'a pornon from 1536 onrardo, a council which follomod him rhorovor ho ront. Thoro in a ntrong ouggostion that tho organioation tightonod up about that timo, and that thoro roally rao a difforonco botwoon tho practico of tho firat half of tho docado and that of tho oocond.

Frequency of mootinge is a point that, in tho aboonco of rogiotoro, mat nocoosarily oocapo prool. Horo again, a Ior piocos of oridence cnablo us to drap a tontativo concluoion or tro, rithout boing ablo to claln that 80 havo ootabliohod a cortainty. As lato as llovombor 1535 Cranmor had to dollvor a copy of cortain articloo, which ho had dram up, to tho blghops bocauso tho council nas not oltting, ${ }^{2}$ whilo in tho yoar after wo bogin to get repoatod reforonces to froquont ooosiono. Tho council sit ovory day to diotuso lottorg brought by tho Fronch ambagaador. 3 Thoy olt dally, "so that oultoro wuat abide thoir good hour".4 Cromell cannot fulfll hio promioo to sok Audeloy for a nrit of attachment bocauso council wootingo have taxon up all his timo. 5 Tho council has boon oitting daily With foreign ambassadoro, ofton from morning t1ll night, so that no auste could bo honra. 6 In octbber 1538 \%0

1. Abovo, p.389.

3. I.P. $x_{0} 748$.

5. L.P. XiIi.I. 91.

6. Ibid. 659. Sin., Ibld. 1015,1149.
2. L,P. 1x.741.

4. Ib1d. 789. 
aro told that tho lordo ait daily in council, and a for montho lator that tho king'a counc1l alta dally but thoro 10 no noro.' Again thore is a ouggootion that tho council ontorod on a now phaso of its history about 1536, boginning at that timo to woot woro and wore ofton and rogularly. Vory intorooting aro tho surprisod reforoncos on the part of informod oboorvoro to daily nootings in 1538-9; thoy cloarly indicato thot whot wan to bocomo tho normal practico of tho prify counall pao otill somothing not and unusual.

The oarly history of tho clerk of the privy council hoo to sowo extent boen norked out by Profoooor Pollard.2 Ho camo to tho conclusion that re must distinguion botroon a nonlor and a junior clerkship of tho council, romnoratod ilth 40 marko and $£ 20$ reopectivoly, tho formor of rhich eror into tho clorkohip of (the council in) tho atar chasbor, whilo tho lattor doroloped into the clorkahip of tho privy council. Thomas Dorby ras appointod to tho junior clorkahip in January 1533.3 Tho abotract in the calendar of tho documont ristch providoo proof of his appointment himoo oororal intorooting and oignificant facts. 4 To bogin Fith, it is not a patont of appointwont, or ovon a rarrant to tho groat soal ordoring such a patont. It is a rit of privy oogl ordoring tho chancollor to $10840 \mathrm{a}$

1. L.P. xi11.II.703; xiv.I.381.

2. E.H.R., IX27il(1922), pp.3451f.

3. L.P. VI.105(24).

4. Tho original is P.R.0. C 82/664/25, givon in App.A(V). 
lottor patont addrosood to tho troaouror of tho chambor, aubhoriaing tho lattor to pay Dorby hio nalary of 220 and othor omolumonts duo to him. Tuko ras to tako a copy on hlo pooko of rarrauntoo" ao his only basis for parmont. Had Dorby posoonood a patont of appointmont, hlo oalary rould havo boon paid on production of a rirt of libernto. ${ }^{2}$ It 10 thoroforo cloar that he ras not apnointod by lotter patont. liow it 10 knosm that the senlor clork of tho council, tho clork of tho otar chambor, rao apnointod by patont, 2 whilo no patont our viveo for Paget, tho firot clork of tho prify council about Thoso position ro can hare no doubt. That ho novor had ono is strongly indictod by the lact that thoro aro no loon than throo copios of tho famous firot ontry in tho privy council rogioters, made in tho sixtoonth and oarly sorontoonth conturios, Fhich are endorsod ao tho "originalo of tho offlco of tho Clarko of tho Consolln.3 Tho clork of tho prify counc1l mas therefore apparently appointod by tho king by rord of wouth only, with tho assont of tho body risich ho ras to norvo. mis is fairly definito proof that Dorby'o clorkohip bolongod to that lino of dorolopmont rhich lod to tho clorkohip of tho privy council.

Socondly, it wuat bo notod that tho privy ooal doocriboo

1. CI. aboro, p.219, n.1.

2. CI. Edon's patent, L.P. IV.6490(1).

3. P.R.O. SP 1/162, 11.51-56. 
tho offico in ouootion as that of tho "Clarko of our Counoalli attonding vppon our poroon". To havo arcuod that a dolinito moaning attachod to that torm, though an official doolro to havo a council alrays in attondance on tho ling doos not provo tho oxtatence of ouch a council as an organiood body. It $\$ 111$ bo oafest to uso caution in thio rospoct. Undoubtodly counc1llors attonded the king and formod an innor circlo within tho largor unit, but thoro is nothing whatoror to ohow that thio was anything wore than a loose and informal group of won who attondod or failed to attend as occasion offorod and co the king's choice fell. Tho difforonce botwoon tho "councli attendent on our person" and the privy councll 1100, as wo bevo oaid, in that rather intangible point of organiogtion; it 10 tho difference betwoon on informal group and a formal institution. Novertheless, the privy council dovoloped from the council attendant, and this prify 800 proves onco noro that Derby 783 appointed, in 1533, to tho clorkship of the budding privy council. It is of the greatoot intorost that thio clorkahip had apparontly boon racant ofnce 1512, for Richard Edon is montioned as hio laot prodocooror, and ho had hold tho sonior clerkship sinco that dato. ${ }^{1}$ Tho vacancy in tho junior clorkship thus coincidos with Tolsoy's cupromacy, and Dorby'o appointment at the boginning of Cromoll's rulo and as tho

1. C1. L.P. 17.6490(1), and A.F.P01lard in E.H.R., $2 x \times 5711(1222)$, p.350, $\mathrm{n} .7$. 
consecuance of an appoal from him to Cromsoll, 1 providos an important cluo to Cromroll's attitudo to tho counc1l. It nocmo that from tho flrot he intondod to organloo tho informal "innor ring" into borothing noro inrititutional, and that ho bogan by roviving its clorkohip.

On tho other hand, it appoaro that the nppointmont hold Iittio 1mediato administrativo algnificanco. Dorby continuod to hold hie clerkship of the olgnot, rorked in the olgnot office, and ras novor for yoaro reforrod to othorrico than ao clerk of the ol mot. The only oridonco of hin rorking for tho council is contained in tro notoo of buginoon to bo trannactod rich bolong into tho nooona half of $1536 .^{2}$ Horiovor, thore ras a dovolopmont in hio caroor an clork of the councll which is of the greatoot 1mportanco to us. In Larch 1538 ho appeared in the expense accounto of the tronsuror of tho chambor as "clork of tho privy council".3 Te may doduco ilth oome confidonce that an offico doscribod in certain tormo in that vory corroct and offlcial account rould rightly be called by those torms, and thet Dorby ras indood otylod clork of tho privy council by 1538. Exactly whon "pripy" ontorod bio titlo ro cennot toll, bat 1 t wast havo boon at somo t1mo botroon 1533 and the ond of 1537. Tho dato of tho account provos nothing

1. A wonth or trio oarlier Dorby had complained to Cromell of ill-uoago and dostitution (L,p. $\nabla .1068$ ), and his appolntmont in January 1533 rag cloarly in anotror to that appoal. 2. L.P. $21.767,850(11)$. 3. L,P. X111.II, p.528. 
ad nono of Tuko's booko ourviro botroon 1531 and 1538. It thus follors that a wan rho rao doscribod no clork of tho council attendant upon our poroon in 1533 roa proporly oallod clork of the privy council by 1538. Tho inforonco is that the informal had changod into tho formal body ot oomo point botwcen thooe tro datog.

Fhilo tho oridenco for official intontiono and inotitutional dovolopmente is Ialrly otrong, it cannot bo olaimod that the crontion of a clork of the privy council rooultod in any ofidence of practical changos. Tho ocanty counctl rocorda provido no oridence of any ono clork doing council rork in those years; we have seon that Friothogloy would writo out an agonda, 1 and he wao not ono of tho many clorka of tho councll discovered by Profoseor Pollard.2 Tho otrangoot part of the wholo story lo that Dorby ras appointod oocrotary to tho counc1l in tho Foot in April 1539; 3 though ho 101t London, no aucceosor 808 appointod to him 80 clork of tho (privy) council while John luttort got hio clorkohip of tho olgnot.4 Tho clerkabip of tho olgnot wao, wo knop, an offlco roquiring

1. Abovo, p.394.

2. Pollard oays that "tho fourtoonth contury difficulty of dotormining mother cloricus de conolilo woans a clork of tho council or worely a cloric on tho council dooo not troublo uo under the Tudorg" (loc.c1t., p.351). But mould not a ourvival of that difficulty oxplain why Bodoll and Layton aro described as clerko of tho council \{1bid., p.3491. I? Fo do not know that thoy roro that, but ro do know thet thoy roro councilioro and in ordora.

3. L.P. Xiv.I.743.

4. L.P. IIV.II. $435(2)$. 
peroonal attondanco, 80 that it ooomo roooonablo to conoludo thet tho other offlco 700 a olnocuro, or at loant did not roquiro any ono opocially appolntod poroon to do 1 ta work.

No wore is hoard of tho clork of tho privy counc1l unt1 Auguet 1540. Tho eirat ontry in tho roglotor, on 81r llarris IIf colas pointod out, "alfordo noorly ao otron: prooumption that a olork of tho Council ras than appointod for tho flrot timo, es thet the Procoedinge of tho Council had not boforo been recorded", 1 and indeod tho otrango obnenco of tho clork of tho privy council Irom April 1539 ontardo can only woan that no reglotor rao kopt until Pagot'o appointwont. Dorby Wo8, then, a clork of tho councll who could proporly bo callod clerk of tho privy council, but ho did $11 t$ tlo is any rork in that capacity and could corbino tho offlco rith a clorlsahlp of tho signot which kopt him vory buay, and a oocrotaryohip rhich remored him pormanontly frow tho nolghbourhood of tho prify counc11. Pagot'o clorkohip 7as, in contraot, a roality. Noverthołose, it is of eroot of gniflcanco that tho clork of tho councll attendant camo to bo callod clork of tho privy council oowe time before tho ond of 1537.

This quostion of tho clorkohlp has ralood a problom fillob It will bo bost to diocuso boloro 70 go on to tho last and wost 1. Micolas, A.P.C., V11, D.11. 
important charactoristic of tho privy council, itn pornonnol. That problom is tho uso of tho torm "privy counc11". It lo ofton omployod by forolon ambarnadoro, but thols uno of it proveo nothing for the conotitutional ponition of tho council. Thoy vore uad to tho naso from tho prectlce of thoir orm countrios and habitualiy roforrod to tho kinc'n chlol councilloro as his privy council. Nor in mach to bo mado of tho term Then it is unod soworhat $100001 \mathrm{y}$ and frooly by Engliohmon. Horever, it in of intoroot to noto that Gardinoremployod it ao oarly ao 1532 in addrosoing Cromioll, and that in 1535 an ominont laryor might spoak of giving inforwation to "tho kyngo is his privie Counsaili". 1 Tho rattor is complicatod by tho lact that some roferenceo to tho privy council in tho Lottors and Panera reveal thomsolvos in tho original ao roforoncos to tho king'g "honorabyll Councoll".2 Nor can fo placo too wuch roIlance on a mention of tho "provy Corncoll" by $n$ roll-Inforcod man Ilke Lord Liglo'a London agont, ovon no lato as January 1537,3 or in tho fact that one of cromioll'n lottorn of 1534 is addrogsod to "my voray good lordes, by lordoo as tho latigoj most honorable prype Counco1 ", for tho addroso risg witton by a clork. ${ }^{4}$ yot a:l thooo aro pointoro to a moro comion uno of the torw.

1. L.P. V.1245; P.R.0. SP 1/91, 1.216 (L.P. V111.518).

2. E.E., L.P. V11.828; V111.954.

3. L.P. XII.I.195.

4. P.H.0. SP 1/86, 1.58 (L.P. V11.1271). 
Discusgiono of thio quodtion havo uounliy not fol lod to notice sir Robort Fingfiold'a lottor of Fobruary 2535 in willoh he clained momorship of the privy council for fourtoon yoarn. llot only tas Hingfiold a "valn and carmulous old man" who had spont his privy councillorohip at Calaln, 2 but tho orleinal of bio lottor skorio that ho wao not implying tho oxintonco of an organisod prify council of which won rioro orrorn, co tho oxtract in tho calondar makos his do. That ho actually wroto ras: "I as oon of thooso rhlch hoth ben ororno of tho kyngoo Corncell above $2 x^{\text {t1 }}$ yoryo past; \& Loyth, of hlo pryvo Cormcell above xilif yoryc I haue Contyruyd." Thio loatoo littb doubt that he was not thinking of the privy council no an organised institution, but acrely of hiecolf no ono of tho innor ring of more confidential counciliors diotinct frod tho ordinary councilloro. Sirilarly, nothing noro formal is lapliod by the oath of tho pileries of Eraco fho orioro to "azpulso all villayn blodo Irom tho and lymgeo eraco \& hio pritoy couns $\cos { }^{n} .3$

Howovor, tho nawo ras boginning to bo usod in a ray that can only be doocribod as official. In octobor 1536 tho oarl of Sussox, ono of Honry'o loading councilloro, ripolso of a lotter recolrod Irom loy lord priveooalo \& othoro of tho prify

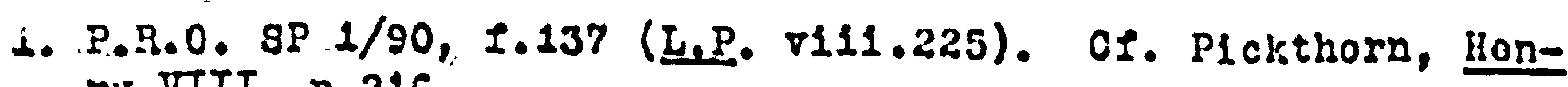
IY VIII, P.216.

2. A.F.Pollard, in E, Il.R., $2 x x+11(1924), p .45$, n.1.

3. P.R.O. SP $\left.1 / 109,1.110^{\prime}\left(\underline{L}, P_{0} .11 .87211\right\}\right)$. 
counsayll"..$^{1}$ Loro fiEnlficant ot1ll, tho king himoolf wontionod his prify council in hia annior to tho robolo' domando, 2 and a lettar from Badior of soptembor 1536, in which bo roports a conversation if th Honry, providon anothor examplo.3 The king ranted the council to asoonblo at Findoor. "And 00 , quod he, ryyto to wy lorde pryvoy ooolo and wonde him worde that lorde Admyrall is here; Mastor Comptroller and the bisohop of Heroford be horo; and pray hil also, guod ho, to cor hithor indelayedlyo; and thon, quod,be, ro ohall oono be at a poynte. And, quod ho, in caoo wy lordo Chauncolour bo nere London and all that bo thoro of tho prorge counsalle, pray wy lorde provy sealo to bring thom oilth hlm." Cloarly, to Henry tho term prity council olgniflod a diotinct body ilth cortain membors, not just a vague inner oirclo of councillors whom ho could pick at fill from largor numbers. Tho lact that the privy council ras not thon fith the king goano nothing, for thio aas during tho criglo of the pligrimage of grace then king and council rero oomotimos oeparated. Two jearo later, a proclamation Lorbado tho printins of booko "onles ppon examinacion mado by soso of his gracio Priule Counorylon. 4 surely ro aro justifled in concluding that by tho

1. P.R.0. 3P. 1/108, 1.116 (L.P. 211.727).

2. L,P. 21.957 .

3. P.R.O BP 1/106, 1.217\% (L.P. X1.501)

4. B.if. T1t.B.I, f.515 (L.P. XI11.II.848). Th10 10 a voronteenth century copy, but thoro is no reason to doubt 1:0 accuracy. Not only doos it ombody opellingo onsoloto by 
lattor part of 1538, at any rato, tho prify counc1l zan an officially recogniood inotitution. Again ro haro had to notice a cortain importanco attaching to tho yoar 1536 in connection with tho dorelopmont of the innor into tho privy council.

Thore remalns the question of the poroonnol of tho counc11. It is clear that there woro largo numbers of won of varying degroo of importanco and rarylng functlono calling themselros councilloro, with a conooquont diotinction botroon an "inner ring" and "counclillors at largo", long bolore tho privy council 803 Iinally ootabllohed. In 1533 tho "lordo of the council" comitted tho exocution of cortain astiero to fire men all of phom wore klag'o councllloro - Sampoon, Foxo, Iregonuell, Oliver, Carno - a diotlaction whlch 1aplleo that the inner circle was well developed. 1 The nazo of counclillor was bestored on locel gentlomon like 815 Edward Ouldeford of Bont and 8is Roger Tormoend of Yorkhblre, helther of whom oror attended tho council propor. ${ }^{2}$ Floher ias interrogatod in tho presence of somo wen knom to be loading eivil sorvanto though not inner councillors, but thoy rere doscribod as councilloro.3

tho timo it ras made, but it aloo in ono place montlono tho king'o counc1l, oo that thoro is no question of all releroncos to tho council haplac boen exondated by the addition of "priry". Tho proclamation 10 tho ono mblob Cromell told Bonner ras mado by tho councif) (c1. Orafton'o reforonco to Cromeril's lottor, LeP. I111.II.972).
1. L.P. $\nabla 1.1490$.
2. L.P. V11.630; xi11.II.34.

3. L.P. Vil1.867(1): Bodoll, Aldridgo, Layton, Curron. 
The chiof justice of Ireland and the lord wayor of London roro both orom of tho council, but that did not mako thom momboro of that council which wo are trying to trace.l The moot interosting and complete liot of thlo outer ring of counclllors within the contral body, though it conthing only "outer" councillors about tho court, is givon in a list of councilloro "loarnod with othor his counsol at 1argo" who walkod in procossion at the coming of snne of Cloros.2 Thoro wo find, among othere, tho 1 at offlcero of tho crom ao woll as many of the leading cifil oerpants of tho day: Potor Vannes (Latin oocrotary), Sir Richard Featon (undertroagurer of tho exohoguer), Sir John Milliams (mastor of tho jowola), sis dohn Dauncy and Richard Pollard (general ourveyoro of crom lando), 81r Brian Fuke (treasurer of the chambor), the troasuror of firot frulta, and the officers of the court of auswentationo. The diotinetion betroen tho inner councll and counclllors at 18580 ras quite definite by the ond of 1539, and tho latter by thon containod some of the king'o chlof servanto.J

1. L.P. I111.II.504; Add.1053.

2. L.P. X7.14, P.5:

3. The list of noblemen to bo oummonod to a nootins at Heotminster, dram up probably for 3 July 1536 (L, p. X1.5[1]) doos certainly not rofor to a mootins of ol thor the inner council or tho counc1l at largo. It may bo concornod al th a meoting of the fas members of tho houdo of lordo (parllament then eltting), or with a "great cmuncli" of the archalc typo, callod for Boxo formal businosB. Tho ordinary council rould not hape included all thooo poors, but rould haro includor a good many othor men not noblo. 
How definite thlo distinction was in tho oarly part of

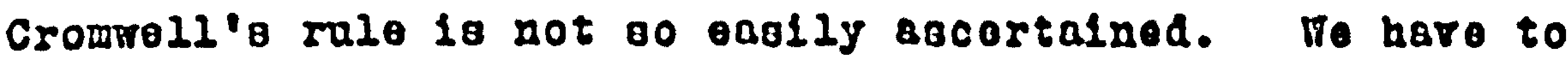
rely on abbesadorg' Ioports, and thoro aro not so wany of those. In Auguat 1533 Chapuyo me told to explain hlo business to the council; ho found them in a houpe twonty-two miles from London and ras ontortained with hasing. On that 00casion tho council consloted of Gardinor, Crowrell, and Rlohard sampoon, dean of tho chapel.1 A Lew dayo lator Chapuyo met the councll at Findsor, and this time thore woro prosent, in addition to thoso throe, the duke of suffolt, tho grost chamborlain (the oarl of orford), and othors. ${ }^{2}$ In llay 153t a council moeting was attendod by Norfolk, Exoter, Fitzallilam, Paulot, Rocheford, the blahop of Ely, and Bir Mllilam Klngaton, the captain of tho guard, Jhich l00ia woro like a full o00810n. 3 Eron more councillors zore asoomblod whon oomo rery particular buginess had to be trangactod. On 15 lay 1534 Chapuyo was callod to woet tho council at Festminstor, at ooron o'clock in the worning, in order to be givon an offlelal account of tho act of succession and to hoar complaints agalnst tho obotinsey of Katharine and Hary who refusod to take tho oath. ${ }^{4}$ Tho occagion was moant to be Improsolve; thoro pao a Latis haranguo from the almonor, Edrard Foro, and an acrimonious diocuaglon onsuod botren indifidual councliloro and tho ambasoador. For

$\begin{array}{ll}\text { 1. LeP. V1.975. } & \text { 2. Ibld. } 1018 . \\ \text { 3. E, V. V11.726. } & \text { 4. IbId. } 690 .\end{array}$


that reagon, presumably, an oxcoptionally largo number had boon brought togothor - Lourtoon councillors and "all the principel judgog". The councllloro included all the farlllar mombero of the inner ring except Gardiner, Fitrwilliam and ouffolis, axd some whose connection with the councll was moro interwittent: Cranmer, Loe of York, Audeloy, Horfolk, Exoler, Hiltshire, Cromrell, Stokesley of London, Tunatall of Durham, Goodrich of Ely, Sampson, Foxe, Paulet, and Kingoton. The vory lact that the judges rere aloo prooent indicates that the inner circle had not yet developed into an organised body. Within tho large body of mon called councliloro thoro was the cortain inner group, numbering perhaps fiftoon to twenty, but with no degree of lixity about its composition. Those aralloble, or those whow it was desired to call, rould asoosble, and the number and persons rould rary froely according to the nature and importance of the busineso. This is not jot a prify council.

The next otgge in the derelopient camo during the pllgrimage of grace. Te hare seen that an imediate conoequence of the rebellion was that crowirell retired from the centro of the stage, and that the council as a body came to tho fore. There rere also olgng of a now permanency in the councll's nembership. In his reply to the rebelo' domands Henry garo this list of his "privy council": ${ }^{1}$ Norfolk, Suffolk, Exeter,

1. L.․‥ $\times 1.957$. 
Shremsbury, 0xford, Busoex, sandoo, Fitzwllliam, Paulet, Foxo, Sampon, and Gerdiner. To thooe nameo waot bo addod, at any rate, Cranmer, Cromell, and Audeloy, oll Int1rato cauncllloro but also wen whom the robelo had olngled out for attack, and Whom it was therolore riger not to mention. Thlo councll corretponds very largely with a llot of loading councilloro which could be derived Irom oarlier eridence, but woro lmportant is what actually happoned during the otrugglo wh the north. Some of the councilloro were aboent in tho 1lold, Norfolk and Shrerabury nearly all the time, and Buffolk, Kingoton, Paulet, and Rusooll for short opello. They recolred moot of their inotructions in lottors olgned by the council as a whole, and these olgnatures roveal a councll organlood on the lines of a reotricted and flsed mewborahip and not difforent in any esoentialo from the later privy council.

The signatares show that betreon 14 0ctober 1536 and 8 April 1537 the folloring councillore wet on sixteen soparate occasions: Cromell, 0xford, Sus80x, Foxo, 8ampoon, Kingoton; Audeley, Crowrell, Sussex, Foxo; Audeloy, Cromell, Bussex, oxford, Foxe, Sumpion; Audeloy, Cromroll, Oxford, Buserer, Sandes, Foxe, Sampon; Audeley, Norfolk, Crowell, susoex, Foxe, 8ampoin; Cromell, Audeley, 0xford, Suober, sampoon, Paulet; the same with Foxe and Kingoton; suffolk, Cromell, Sussex, Foxe, Paulet, Kingoton, Rusoell; 8uffolk, Audeloy, 
Cromell, Sussex, Foxo, Sampoon, Fitzrllllam, Peulot, Rusooll; Sulfolk, Cromell, Exetor, Suooox, Foxo, Sampoon, Fitzwilliam, Paulet; Cromell, Sampg̣on, Fore, Paulet, F1troll11am, Fluegell; the sarse with Kingoton; Cranmer, Audoloy, Buffolk, Foxo, Crowwell, Paulet, Pugsell; Cromell, Sampoon, Paulot, Klngoton, Fussell; Audeloj, Suffolk, Cromwell, Boauchamp, Foxo, Sompoon, Fitzwilliam, Paulot, Kingston; Cromrell, Audoloy, Suflolk, Tunstall, Foxe, Sampon, Fitzilllam.1

Few of the nameo appear only once: Tunotall, perhape because a man of his knom conservatife opiniono was kopt aray from the centre of affairs at this juncture, Noxfolk and axeter because thoy were nearly all thece wontho engaged in Ilghting the rebels, Beauchamp pho was but beginning, to make himeolf 101t. The rare at tendance of Cranmer, Audeley, and 0xford was no doubt due to the fact that they wore the threo "Inner" councillors appointed fith a number of councilloro at largo to form a resident council in London, to attend on the queen while the troubles lasted.2 Cromroll olgned erery one of these documento, so that we may take it that ho norwally attended, deapite the evidence for his occasional aboenco from the council which was mentioned abore. All except threo of the letters are dated Irom royal palaces - Findoor, Rlchmond,

1. L.P. $21.701,788,799,885,1040,1228,1237$; X11.I.201,332,333, $505,558,636,667,846,864$.

2. L.... $x 1.580(3)$. 
Greenvich, Westminster - clear evidenco that hero we have a council attending on the king wherevor he went. The threo exceptions, two from the Rolle and one from Chriot Church (Londion), prove that the council would occaolonally meot at Cromell's house and further confirm his outstandeng pooftion, thinly disguised by the employment of an organised counoil.

We may therefore now draw up a liot of the innor council of the yeare 1536-7.

Thomas Cranmer, archbiohop of Canterbury.

Sir Thomas Audeley, lord chancellor.

Thomas Howard, duke of Jorfolk, lord treasurer.

Charles Brandon, duke of Buffolk, president of the counc1l. 1 Thoma lord Cromell, vicegerent in epirituale, losa privy seal, etc.

Henry Courtenay, marquess of Exeter.

John de Vore, oarl of oxford.

Robert Ratcliffe, earl of suseex.

Cuthbert Tunstall, bishop of Durham.

Edward Foxe, bishop of Hereford.

Richard Sampson, bishop of Chiechostor.

William lord Sandes, chamborlain of the hougohold.

Sir Filliam Fitzrilliam, lord admiral, troaguror of tho household, chancollor of tho duchy of Lancaster.

1. So degcribed several times in 1537-9: LeP. X11.II.1155; ziv.II.619(11-13,37), 780(17). 
8ir Filliam Paulot, controllor of tho houoohold and maotor of the wardo.

Sir Mililam Eingoton, Pico-chamborlain of tho housohold. sir John Rasooll.

To this liat of olztoon mon thore ouzht to bo added 0oorgo Talbot, oarl of Shroizabury, lord storiard of tho housobold, who ves alvays absent and had boen lnoluded in tho kelng'o liot of his privy council with the proviso "ahon ho way comen, and porhapo already Sir Edrard Seymour, Vlocount Boauchand, who wao only on the threshold of hlo caroor. The noot olenlfleant omisaion io that of Stephon Gardinor, blobop of pinchootor, duo to his absenco as rosidont asbasoador in Franco. Thoro io good reason to think that Crommoll had dollboratoly rld hlwoolf of his wost ablo and tenacious opponent in tho counc1l, but =0 can hardly doubt that Gardiner rould haro had to bo includod In: tho list of inner councilloro if ho had boon in England.

To therofore have hore a total of ninoteon, tho oaso nusber as that of the establiohed priry councll of Auguat 1540 . Lore important yet, if tho clorical councilloro bo romored wo ohell arrive at exactly that council rhich a docusent of about october 1537 deocribos as "to bo had at this tymo in tho klngoo most bonigne Remombrauncen: ${ }^{1}$ Audoloy, iorfolk, Suffolk, crom-

1. B.N. Tit.B.1, I.497 (L.P. Xi11.I.1). Tho dato of tho 110 ot mast bo bolore 18 octobor 1537 whon Boauchamp rao oroatod earl of Hertiord (L,P. I11.II.939). 
rell, Exotor, Shrornbury, Oxford, Bussox, Boquohamp, Sandon, Fitzwillam, Paulot, Ringoton, Rusooll. Tho mannor in whion the list is rritton dom, bracketod togethor fith "Tlie Conooill" against it in tho lort margin, horo hor dofinl to tho oogrogation of tho innor circlo had bocome by thon. Profoooor Pollard has doducod a councll for January 1540 which includoo these same men, excopt that Exotor and Shrorobury had droppod out by doath, and dingston for a roason unknotm bat boon put among tho councillors at largo. Ilo han also shom hor the porsonnel of the councll changod organically to givo tho ninotoen wen rho head the reglotor of Auguot 1510.1 Boro to havo conclustive prool that by the oocond half of 1536 the innor council had achioved that lialtation and firity of nowborahip which charactorlood the prify councll propor.

Let us asrohal our conclualono. To hevo ooon that in 1536 the follozing changes in tho counc1l appoar to hare taken place: attendance on the king bocamo regular, bootingo Gror very Lrequent, there rero "ofllcial" roforonceo to a prity council by that name, and - wost lapdrtant of all - woaborohlp becaso Ilxed and personent. Tho crlolo of tho pllgrimago of eraco revoalod tho derolopment of tho council; wootingo becomo regular, businese ras tranobctod by tho council as a mhole, councli lotters roro algnod resularly by boso of tho

1. E.H.R., $2208 i 11(1923)$, pp.431. 
ninetoon "Innor" counc1120ro. Add to thln that at oomo t1mo botzoen 1833 and 1537 Thomas Dorby, tho clork of tho Informal council attondant, bocaso clork of tho erluy council, and ro can no longer refuse to adalt tho conolusion to rhich wo aro bolng drivon. Tho privy councll wao odtabliohod an a conoclous moasure of organioation by tho oocond half of 1536; in all probablity, it ras formod oudaonly Irow olemonto dovoloped orer the lagt yoar or tro whon tho robollion in Incolnshire mado necos3ary Cromoli'o tomporary nithdramal into obscurity.

It wight bo thought that ol th tho ond of tho criolo tho provious position 880 ro-ootabliohod, and that tho priry council disappeared again. Horioror, thoro jas no chango when the robele were defoated. Though wo do not got oo many letters oignod by the council as can bo found for tho critical montho of 1536-7, 1 there are tro ouch lettoro for tho 280 t three yoaro of Crowrell's oupromary which indicato that tho privy council continued to exiot and that ito nomborahip did not change. It rould be tireoome to give any woro 113to of councillora; way. It ouffico to oay that tho lottoro aro olgaed by eloron and goton councillors rospoctively who oll bolonged to tho pripy council of $1536 .^{2}$ That thero roro wany ouch

1. The preoervation of thooo lottoro 10, in any caso, duo to a modern transcribor. Thoro aro no orlginalo among thon, but they rere copled mith groat caro and aro porfoctfy rollablo. 2. L.P. XIII.I.028; II.068. 
lettors is cloar from tho pordo of oomo of Crowroll's corroopondonts rho. stato thomoolvoo to bo anoworing lottoro writton by Cromoll and othoro of tho counc11. 1

Thero is some rathor more indiroct orldonco. In soptonber 1538 Cromroll held a councll attondod by Audoloy, Cranmor, Iungtall, and others; the aboonco of tro prify counclllora, IJorfolk and Sussex, zas romarkod upon - thoy foro at court.2 This ohors that tho prity councll ras not incopablo of oplitting up, some of its aembers attonding tho king and othorp Cromell. This is most cloarly ohorm in a lottor fron throo prity councilloro (Southampton, Tunotall, cingoton) to Crowvell, of September 1539.3 Thoy wore rith the klni who had ordered them to transalt certain of hlo flohoo to tho lord privy seal. Tho visit of the count palatine ras oxpoctod; be ras to go to Mindoor and 000 tho king, but 19 h10 businoso was "of no greato raight, than ho way on thuroday rotorno to 10ndon and thoro boo angrerd by our Coungallo. And than roo deglred to knore his pleaser shich of his Counsallo bo rold haue thero, nameng vato his my lord Chauncelons, my lordoo of Norfolch Suffolch 0xford Susoox and Borford," to which $110 t$ tho king aftor oomo thought addod Paulot ("Liotor Troasoror"). Although the king clearly thought of tho prify counc1l 80

1. E.g., L.P. X11.I.639,677,1221; II.275; I18.I.010.

2. L.P. XI1i.II.446.

3. B.ג. IIt.B.1, 1.401 (LeP. XIV.II.183). 
boing in London, oron tho won at 71ndoor bohorod $11 k 0$ a propor council. After tho king had callod thom and ohorn thom a lottor from Cromedl thoy "ront to gldroo and rod your lotteres, and conoldered tho contontos therol aanol ao our olaplo fittos could sorue vo; and that doone 800 maro our ropalro vato hio sald walooto", a dociolon bolng arritod at "aftor long conoultation". Tho prify councll wao an accompllohod Lact, but 1 to mootingo and compooitlon poro, to a cortaln extont, otill gubject to tho sing's doolroo, and it had aloo to contont with tho problow of tho groat minlotor.

There, aftor all, 10 Crosroll's placo in all thlo? It oeemg almogt as though hio oupremacy rould havo to bo oorlougly doubted If Irow 1536 bnvards thora rao an organlood prity counc1l whioh transactod businoss and gorornod England. That question has already boon anstrerod; wo osm abovo whet tho truth was about Cromroll's rolationo 1 th tho councll ofon at a time thon it had alroady boon oraanlood as the prity council. There ras a prity council, but it remalnod under hla control. In hio laot years ho had establiohod hiasolf oo 11 rmly that ho could alford to otay arry frop court, and nlo corrospondonco shorr that he no longer accoupanlod tho king on progreas. On ouch occasions oowe deaboro of tho prify councll sould bo with Henry, while othoro might be aooerblod by tho lord prify 000 . To this extent the picturo of 1536-7 nas oxcoptional: a criolo 
and the apparont oclipoo of Cromoll had biron tho councli a degroe of unity, dofinitonoos, and indopondonco which it wao not again to achloro until aftor Crowroll'o lall. If tho prify council wao a lact lrom 1536, Cromoll did hio boot to wodify thet lact to fult his om oocondnncy.

Yet Cromsoll Fao, boyond roasonablo doubt, ronponolblo lor the creation of tho prify council. Ho rao tho ann who undor tho king rulod England in tho yoara rhon tho nor inotitution Has rorked out, and nothing of that kind happonod without hio knorlodgo. To havo ohom that ho bollorod in conc1llar governmont. Tho concontration of poror and admlniotration in a contralisod body wao part of hio polley in tho marchoo of England; bo had ootabliahod a "council" to adalalotor monsotic lando, and plannod anothor for rardo' lando. Trico in his years of powor ho notod dom in hio wemoranda that bo wiohod to do somothing about tho counc1l. In Juno-July 1534 he ocribbled on the back of a letter "To remembro tho Bymb for tho establyshmont of tho Counsaylo", 1 and in 1537 wo haro another note, "Item touching tho ksag'o council". 2 It 10 tho lirot entry which 10 particularly intnrosting. Tho ootablishment of the council - that could moan only that oomo sundawental rolorn wao belas planned for tho king'o councll as

1. LeP. Add.944. Tho date 10 given by tho wontlon of a froo olection for the monastory of BIndon - CL. LeP. r11.821. 2. L.P. $211 . I I .1251(3)$. 
oarly ag 1534. That Croctroll'o plano wero wao ohom whon tho crisio of 1536 ouddonly produced tho organlood priry counc1l. That could not haro beon the rork of a mosent but mut haro reoted on preparationo, on earllor and dellborate dovelopwont, and cromzell's noto protos who was at the back of 1t. Ho himself planned and dorelopod tho councll by 'wlthdraxing $1 t$ more secret together' and by gloling it the organieation of tho prity council. He did not nood tho adrico tonderod in 1538 by Sir Philip Hoby who thought ho had found a now and uoothul pattern in the omperor'o council, for by thon tho Englioh privy cbuncil was ostabllohod. 1

On the othor hand, cromroll can hardly have falled to 000 that a fully dereloped prity council would dotract from hlo orm supremacy. Indood, ge have ooon that thero aro oleno that his rule becamo 1080 unquedtioned and 1000 unsivallod towards the ond of hlo lile. The ner prity councll, organiood and pormanent, proplded an arena for the otruajlo for poror under the crom rhich had not exloted in tho 01d, inforsal, and iluctuating "inner council". Thlo 10 not tho place to regoarao the party otruggles of Cromell's lant montho; tho orldonoo is scanty onough; in all consclonoe, and what there 10 hao boon

1. C1. L.P. I111.II.974(2), D.416, Too wach hao oomotizoo boon made of Hoby's notos. He rao puttluc dorm rhat hlo expod1tion to spain led him to bollovo rould bo nocoseary for tho bottor admialotration and dofonce of tho roalm, but thoro in no orldenco that his adrico mas takon. Ho cannot bo creditod with the peternity of tho privy councll. 
rerlerred more than opco.' Cromoll'"l fall rao ouddon, but thero had boon olgno of hlo woakenlne position for voll orer a yoar, and it was in tho oouncli that ho found lilo rivalo, not in the ophore of admlniotration. Thore ho romninod oupreme till tho ond, wo mach oo that blo fall wao dolayod by gevoral wooks because there was no ono 0100 who could get money out of parliesent and tako other noceonary otops. 2

Cromell rag, therofore, laced by a dllorma. Wo th ohod to oreate on orgailsed councll for tho bettor gorernmont of England, but ho did not vlob it to endangor hlo orn ouprownoy. Once again 70 find that dual purpose. whlch wung through 80 andch of hio adolniotration - organloation and porsonal ascondancy and onco bealn the somo kind of oolution rao adoptod. The privy councli tro organiood, Eloon a clork and rootrictod wowberohip, provided with a good deal of laportant vork, but $1 t$ was not allored to derelop into 1 to full and final fort. no regibter was kopt and Derby'o clarkaklp was at t1000 a farco; the appointment of Pagot in duguat 1540 sarkod, aftor 011, co dofinito a otop as tho rocord indicatoo. If thoro rao a council book it wes apprarontly kopt privatoly by Cromell hlmoelf, and the oxtant oerios of roglotero begino rightly aftor hlo fall. The whole organisation of tho prify councli wes rorkod

1. The bost ghort account frow tho polnt of rion of tho privy counc1l is A.F.Pollard'o in E, I.R., $2 x 2 \pi 111$ (1223), pp.401.

2. LeP. XT, $P D . x x x-x I$; Horriman, 1.2091.; PIcktborn, Honsy VIII, pD.4281. 
442

out under and by Crowroll, but hlo poroonal control and aocondancy hold it ouspondod. Imon ha hed to rotiro into tho background, 80 in 1536, or whon he dloappoarod altogothor, tho prify courcil bocamo a wanlfoot roollty. Lt othor t1500, 1to nature, 1to rork, and 1 to compotonco poro pororsally wod1fied by tho porsonality of the lord prlyy ooal who had crootod 1t but continued to koop it under hlo control co boot ho whent, and as far ao the otrongth of hio position with tho king allowed. Then that began to roaken tho privy counc1l bocaro 1mmediately woro inportent, and in tho ond Crowroll lound that he had lald out a garden in which hio rivalo could slourloh. 


\section{Chaptor 6.}

CROLWELL'S PLACE III THE IIIOTOKX OF ADLIIISTRATIOH.

Cromell mat have roallood hor tho control of tho couno1l, and of th it tho control of tho machlnory of Eoromment, veo allpping Irom his hands; whothor bo also roallood that tho organisation of the prify councll, carriod out by hicoolf, bad smoothod the path for his adveroarloo, that 10 anothor quootion. In thio norly ootabliohod body, drawn tightly togothor and acquirine a corporate oxsotonco through 1 to novol continulty of membership and Irequency of mootingo, tho oppooltion to Cromwell could gathor otrepgth. Ito varlous olovonto found horo a weeting ground - the diggruntled hatrod of losfolk and the nobles, the ambitions of the riolns een 11 ko Rlcho and Drlothesloy, the foars of the conoortative in rollgion. It rao in the prity council that thooe eroupo also fourd a loador in Gardiner - who was as ablo and urocrupuloud as Crottoll himself, and wore in accord with the agolng king'o lncroaolng ceution and desiro for the rollgion of hio youth. Lloot lapor tast of all, tho ostabliohwont of tho privy councll undorinod Cromell'g indiopenonbility, for it could soomingly oupply tho quality which had mado hit eroat and tako hlo placo whoro hitherto he hed boen unique and undlopptod. So ono but cromioll could adwinlater, until the organloation of a porwarent gororn- 
mont ouggosted that oron in this ho could bo ouporoodod.

noed meo thero of tho lord privg coal nor that ho had taught the council to Eororn ofliclontly and offoctiroly?

Thuo Cromell was coot off and wont to hio doom, but hlo place was not I12led. Matoror abbltiono $1 t$ may haro had, the council could not wake 1 tooll ouproro millo tho old king Ilvod, and rhilo his ohador, Incrooolng in bult and torror, hang over all bio elniotoro. Thoy oottlod dorn to tho todlouo routino of gorornsunt, attompting to do what ono wan had dono for soren yosro, and not waking wuch of o ouccoos at 1t. It did not take Henry long to diocoror thlo; barely ooron Eontho aftor a "raggod and boochorly Eloor" had in oo ungoodly a fashion performod tho last "ofelce" on Crowwell, 1 Honry wao caoting Crowell'o decth in tho tooth of hio council, "oaylng that upon light protexto, by faloo accuoationo, thoy mado hin put to doath tho most falthial sorrant ho oror had".2 But it ras too lato, and tho root of the rolen 10 a oad tale, lacklng both tho oomerhat oxtraragant oplondour of tho roloog joaro,

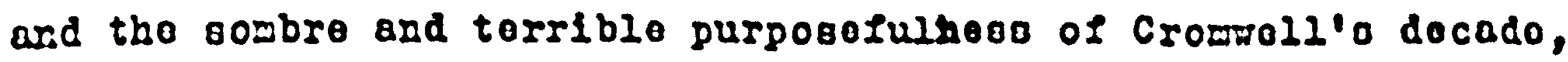
and oxomplifying at orory turn that thoro can bo no glory or greatnes, or oron a decent weabure of ouccoos, wlhout hard Fork, a oot intent, ablilty, and olflcloncy. Thoro 10 no bottor testimony to Crombll's groatnooo than tho undotakablo

1. Hall, Chronlclo, p.839. 2. I, P. 281.590. 
collapoe of tho adminiotratyon aftor hlo fall. Tho forwo and outlinos of the wachino winl ch had rorkod oo roll undor bim remalnod and woro oron addod to, but tho dfforonco nhorod whero it mattered - In tho rooult.

Let us bring togothor tho concluolono whlch havo amerged from thio otudy of ooze aopocts of crompoll'o adrinintration. In tro and a half yoaro ho roso fros noar-axtinction to ouproweporer under the cromn, and ho achlored thio by rorking blo ray up of thin the adainiotration. Ho oproad hio lafluonco by accuralating a nusber of offlcoo mhlch onablod hls to oxarclio diroct control, in particular in tho rarlouo ooctiono of tho financial and oocrotarial organioations. Ao rogardo tho forwer, ho cut short the rloo of tho chambor by waking $1 t$ ono of a number of depertaents, both bocauso bo could not oxorcloo unlimited control over a housohold offlco and bocauso ho rlohod to holp on 1ts oxfoting tondoxcios to bocoso an organlood dopertwent of otate; ho asourod hio orn froodor of actlox flrot by himself bocoming a trosourar for tho king'o wonoy and lator by adopting tho troasurer of firot frulto and tontho ao blo private paycaotor; and ho initlatod tho oyotom of rovonuo courto and in goneral incroaood tho dopartiontalfoation of tho royal financos. The oocrotarlato of tho ol gnot ond privy $00 a l$ woro furthor organised, and an attcapt ras wado in thoory to rootrict the uoe of thooo o0alo; tho privy ooal in particular 
bogan 1 to dornmard caroor which ond od with itn bocomlng woroly a suporfluous otage in an adniniotrativo procooo, whllo cromroll'o pollcy for the olgnot rao olal lar though ho did not intend to doprivo it of 1 to functiono in connoction ol th tho king'o corroopondonco. In pract1co, howovor, thio "rogular" uso of the 80010 was littlo in oridonco whllo Crompoll hlzoole held the roing of govornacht, though it at onco bocamo apparont at his fall. Lastly, ro havo ooon that Crowroll turnod tho informal inner ring of the councll into tho organiood pripy councll, though ho provonted 1to full doroloptont by tho forco of hio peroonal ralo.

Soreral times to have haid to polnt to cloar orldonco of a "dual purpose", of two linoo of pollcy sunnline through CromFell's practico in tho organioation of tho adalniotratiro wachine. To diocoperod a desiro to organioo on burocucratic lines in tho ootting up of tho rovonuo courto, tho thoorotical troatwent of tho 8oalo, tho organloation of tho prity councll. But another dosise has boon ao cloarly aarkod, tho doolro to waintain flexiblilty and lack of buroaucratic orcanloatlon oo as to preoorte crowwoll's porsonal autocracy. Organioation there ras to be, but not to the oxtont of tylng the bando of tho organioor himell. Peroonal aocondancy and a dlctatorial attitude Fe Elght haro orpoctod; organloatlonal actiritloo ard a gonuino dosiro for adalalotrativo rolora fo aleht havo 
hopod for. Fhat wo woro givon provod to bo a porploxing mixturo of tho two, tho woro cortainly truo boonuno it wot uo in ovory oopoct of Crowroll'o adalniotration rilioh wo inrootigatod. Thoro io rathor woro in thio than tho comen huwan falling to rido roughohod whon tho chanco 10 offorod, for horo io a man who doliboratoly sot obout roforming tho gorernmont and as dollboratoly put aoldo thooo roformo. Why did ho trouble at ald to paos acto of parliamont and to orcanioo machinory, whon ho did not apparontly intond to uoo thom? Tho contradiction io ronl onough, and tho oxplonation wuot rooido in tho wyotory of Cromoll'a wind and charactor, oo that it orght to thror somo light on tho poroonolity tho diocorory of which was ono of our otarting polnto.

It ought flrot to bo noticod that tho tro $11 n 08$ of policy more by no woano alraye concurront. Thoy woro oo in tho 11nancial cadiniotration fhoro tho undortatelng of a poroonal troasurerghip wont oldo by oldo with tho furthor dopartmontalloation of tho chambor, and rhoro tho ootting up of tho forwal departmont of tho augmentationo was not allonod to influonce tho informal arrangomonto for firot frulto and tontho. But thingo rere oozorihat difforont in tho other sattoro which havo boon discusood. Cromoll dror up hlo dopartwontal rulos for the Gignot offico in 1534, and tho act orbodylng hio 1doco for tho tro coals ras paosed in 1535. In oach caoo tho organloa- 
tion was followod lisodintoly by obodionco to tho ruloo and lator by an incroaling diorocard for thow. Slallarly, tho prify council ras ootabllohod by 1536 and ronchod 1 to rull devolopsont in that yoar, during tho tirso of tho northorn robellion; aftornardo thoro woro nlgno of a partinl roturn to a loss Iully devolopod orcanloation. It coom, thoroforo, that Crompoll was mast actiro in roforming tho adminintration at tho boginning of his oupromacy. Thon ho took ovor ho bot about ovorhauling the achinory of govornmont and glvins it a nor offlclency, for it had boon allorod to run tom nomorhat undor wolsey and in all probabllity otill woro in tho intorval gince the cardingl's pall. In tho couroo of this ororhauling a number of Innorations noro introducod. Horovor, onco tho organiaation had boen rorisod and tho ninlotor'n inctrumento improved it was 1000 nocosnary to adhoro to tho lottor of oach rulo; Cromele was now wero absoluto in his control and could afford to riok unauthorlood and oron arbitrary action; and for thoso reasons orcaniontlonal aotiolty, oo otrong in tho oarly thirtioo, 583 loos obrious during tho laot yoars of hlo ouproEacy.

It follors that thoro is no 1noolublo inconalotoncy in our "dual purpose". Cromsoll's elrot considoration was tho provervation and expansion of his personni control; this to thow by tho manner in which ho conductod tho gorornont - througls 
hlo private lottero and hlo privato oerranto - 0.8 woll ao by bio accumalation of off1cos and tho riers of contomporarloo who turned to hlo for ororything. Howoror, ho used blo poronal control to reform the adminlotration, and hio ldeas of reform took the ohape of buroaucratic organdoat1on. Cromoll rag, thereforo, not only a wan of groat ablilty and applicathon, but ho was also Eaotorful and roll araro of tho roallty of porror. The picturo of llonry's oorollo lackoy, which 10 oocetimeo palnted, almayo a tool and norer hincell the creftoman, can be diucarded. Hore ras a minloter of real Eroatnego Who ruled because ho concentrated hlo attentior on the rocpono of polfticel poror; he took hold of thom and wado ouro that they rere alrajo kept oharp and oorricoablo. Thero ras, horerer, anothor and wore important ofde to Cromell. Lot content with exorcieins porer and goverarcnt, he dellberately 80 t hinself to reform the adinlotration. Hlo rosk in thlo ophare (which elone hes boon our concern) proreo, es rould prove on infootigation of hio largor rork in otote and church, that bo Fas a ean of 1ceso, a practicel atateanan with a plan for the future. To hspo boon ablo to ohor that in odrinlotratiro wetterqhe put a plan into practico rhlch tho future rao to prove right and requisite.

In a recent diccuselon of the problos of polltical poror, a German historlan of political thought dellnod tho "highost 
lovel of true otatesmanohip", In particular in tho poriod of Machiavelli and Lore, in vordo which have a otrango applicability to Thoma Cromerell. "It 10 a quootion of tho socrot of truly reoponsible polltical action; of tho abtlity to think ahead, ovon while the fight 18 on, to tho ner pormanent order which is to reoult; of tho moral justification of the strusgle for porer which io dorivod from the duty to roplace an outrorn logal order by a nor and bettor one; of the ovaluation of raison d'état as a ploco of mornl roason, not woroly political cleverneso; of tho consequent oelf-rontralnt impooed on the vill to fight, oo that in the ond tho unity of tho woral consciousnese may be presorved despite all the antinomy inherent in the practicel rork of polltice." ${ }^{1}$ Me hare but discussed one, and perhape a minor, aspect of Cromroll'o rork, and re mast not clain too wuch. Certainly ro cannot ascribe to him any resy moral principleo, in the othical oenso usually givon to that term. But he lirod in an ago rhen an "outrom

1. G.Rittor, Dio Dämonio dor lacht (Stuttgart, 1947), p.207: "Es geht un das Gehoimnis wahrhaft vorantrortungoborhsoton politischen Handelns; un die Fühiglsoit, schon in Rünpien oelbst die neue Dauerordnung, die daraus folgen soll, vorauszudenken; un die sittlicho Rochtfortigung des Hachtkamp10s aus der Verpflichtung, eino veraltoto Rochtsordnung durch eine bessere neue zu ersotzen; um die Beriuhrung der staatoräson nicht als blos80 Staatoklugheit, sondero als ein itlick sittlicher Vernunft; um die Selbstboschränkung des kümplerischen Fillens, die daraus Iolgt, 80 dess ochliesolich dio Einheit des sittlichen Borrasotsoino trotz aller Antinomle der praktiach-politiachen Aufgaben erhalton bloibt." 
logal order" had cloarly brokon dorm, whon tho otrugelo of poIitico rao almoot moro nakod than 1 t had oror boon, and whon thio nakeanoss nao for tho flrot tiwo unoquirocally rocognlood by the phllosophoro of tho otato. Thlo much way bo oald that Cromroll wao no woro patchine politiclan, but a ototooman who in erorything oav cloarly whero ho rao golag and had a dofinito intention and purposo in all ho did. Hlo rolorm of tho administrative wachino rao a olenificant point in thio gonoral purposefulness.

This brings us to the question of tho placo occuplod by his administrativo rork in tho derolopmont of tho gorormment of England. The eight yoaro during phich bo vao at the hole were a vital poriod in tho country'o hiotory, in tho biotory of its church, and also of its adainiotrativo organisation. Looked at with regard to what ront before and what camo aftor, the administration is seon to havo boon influoncod eore by that line of Cromtroll's mork which hao beon doocribed as a dosire to organise bureaucratically. It was natural that tho rork of government should show olgns of a nor splrit, of groator onorcy and efficiency, when tho chiol minioter ras a wan who wado ouro of his close personal control of ovory dopartmont. Tho porsonal character of Cromell's rulo gavo to tho adminlotration that strength of purposo and rapidity of action which aro particularly noticeable whon tho 1530 's aro comparad with tho laot 
years of Henry's rolgn. But if ho had dono no woro than infuso a new opirit into an old order, thoro rould bo littlo to nay of Crommoll as an adminiotrator boyond tho fact that ho was a man of vigour who could mako othero work hardor and bottor. That aspoct of his rook died with him, and his truo grontnoos ao an administrator lay in hio roformo. Cromoll conocloubly changed and improved the machinory rhorovor ho found it nocosoary. He was a practical roformor intont on providing himgelf with the boot tool that circumstancoo roquirod and mado possible.

At the same timo, even the moot ompirical of mon mot bo influenced in his solutions to probloms not only by tho nature of his material but also by tho bend of his mind, and crourroll, as tre have soen, ohorred again and again that he had a vory definite idea of the kind of solution rhich he righod to apply. Ho aimed at contralisation; porror nas in tho last resort to reoide in him alone (under tho king, of couroo), and from hin all orders rere to flow dornmardo and outrarde through clearly defined channels. To do this he nooded a buroaucratic orcanisation. In principle ho dioliked all mothodo which omackod of the informal, though be could be very informal indeod whoro it suited his porsonal ascondancy, and he ohorod thio diolike in his tifeatront of the chamber, of tho prify soal and oignot, and of the 10000 "inner council". Crowroll 700 tho flrot 
groat modern reforter of tho adalniotration of England, tho more so because unlike llonry VII ho was only a minlotor and thereforo roluctant to roly on tho royal houoohold. Ilo could bo oatlolied only with a more pormanont and woro sully organiood rachino.

Tho adriniotration which oworged aftor Crowroll'o fall rao therofore difforent in wany rayo frow that which Crowsoll had inhoritod. Hio fall wao nocosoary to rorool tho full oxtont of hio reforto which the ohador of hlo orn orortholelag poroonality had hithorto obscured. Tho royal rovonuo nas not allotted to a number of organlood departwento, and thero wao no question any longer of an informal treasuror, dopondent on tho king plone, rocolving and expending the botter part of the money on which the otato ras ran. Tho oroction of tho courto of lirat fmits and of gonoral surfoyoro pas woroly a logical expanaion of Cromell's methodo which Cromoll himsolf hed found undesirable or unnecossary because of hlo personal rule. The later measures of draring theso departmento togothor, flrot by fusing tho courto of augnontations and of Eeneral ourvoyoro, and lator by including thom under tho umbrelle of tho roformod exchequer, did not dotract from Crowoll's rork; in a ray thoy completed it in that thoy replacod blo porsonal government by the kind of organleod wachinery on..phlch ho had taught his ouccessors to rely. 
The same derolopwont can bo ooon in tho othor branches of tho adminiotration with whlch wo havo doalt. Tho rocordo of the privy o0al havo proved to uo that tho roforwa rhl ch ho had carried out in the dopartmento of that soal and tho olgnet were allowed to como to full frultion whon ho foll; his work in this ophere, too, wos marked by tho tranaformation of tho modierally 10080 and soml-organisod reapons of tho royal vill into the buroaucratic nombers of the modorn otato. The oamo applied to the counc1li tho organloatlon of tho prify councll proper, the bagis of all future devolopsont of gorernzontal bodies, ras certainly tho noot lmportant adminlotrativo reform of Cromell's docade. It, too, almod at anking adminlotration more efficient by waking it moro centrallood and noro pormanent, and centralisation and pormanoncy are tho tro ball-marks of bureaucratic governiont.

Thile tho Dodorn otate was the rork of 1 to groat rulero, whother kings or miplotoro, it would havo boon laposolblo Ii thout an organlood buresucracy. The ner monerchy noodod a ner and different kind of servant, calarlod and falrly socure of his post, and Filling to do hio rork at tho bidding of whaterer goternment rag in porier. Henry VII bad wade a boginning when he picked bio loading alniotero from claooos which had no traditional o2 alm, to gorernwent, but tho tagk ras really a wider one and bocase particularly inportant with tho 
oclipoo of the church. Clorlco in minor ordero hod so lar oupplied tho veot rajority of tho lorior ranke of tho c1011 oorvico, but aftor tho Roformation pooooodion of any kind of orders ras no longor el thor a oufo ray to thooo appolntmonto, or nocessarily oron a rocomendation. Tho nor ototo noodod a ner civil servico, and Cromoll otopped into tho broach With that oyoton of patronage - tho patron-cliont rolationohip, and the advancoment in tho royol oervico of won who had provod themselves in tho uiniotor's sorvico - rhich in 1 to oooontialo lasted until tho adrinistrativo rovolution of tho 1830'0. To cannot hero enlargo on a subjoct if th which ro aro, otrictly sperking, not concernod, but a brlof rord coomod nocosoary in order to ohor that rhat Cromtoll bogan laotod for 300 yoaro, and also in ordor to indicate that tho buroaucratic baolo ras not overlooked for that bureaucratic superetructuro of which we have spoken at ouch length. ${ }^{1}$

Thuo Thomas Crowell, who wiohod to Eake hlo king tho autocratic mastor of a national otato in which the nationalic church rould bo but a sorrant of tho crom, being man of practice and not of theory, dotorrinod to provide tho ner monarchy with a otructuro of goternmont ouf toblo to 1 to noods.

1. Cf. the caod of ono Cromerell's "cllonto" who wao propoted to tho civil oorvice, above, p.350. For a rion on Croprell'o "letherhood" of tho patronago cyotem and modorn bureaucracy, c1. D. Uether, social Structuro in Cnrolino Enslond (0xford, 1948), p.4. Loro dotallod roooorch into this point is otili nocoosary. 
Ho realioed that thio woant contrallootion and organloation, the rosult boing buroaucracy. Ho novor sininhod hlo rork, and local govornmont, for inotanco, rowalnod larcoly unaffocted despite ouch wosouron no the ro-invicorating of tho local councilo and tho otrictor control oxorcinod oror local commlooiono. But in his rork on tho adziniotrativo machino bo mado a considerable and dotorminod boginning on that tranoforwation which has giron us tho Eodorn otato rith a.l 1 to attoncdnt adrantages and evilo. liot all his rook boro frult; tho fact that bo did not croato an autocracy auch os Richollou foundod in France (for that rould ooon to be the noaroot parallol to his intentions) was due to clrcurotances inhoront in tho country and 1 to history - particularly porhaps to tho aboonco of a otanding army, tho fact that Ellaaboth difforod in many mayo quite esoontially frow her fathor, and tho rloo of a nor and militent opirit in the socond half of tho olxtoonth contury to tako the pleco of tho olnost byzantino obodience to a difinely hedged king which charactoriood tho firot half. Uuch of hio Fork, horevor, stood tho test of timo, and no part more oo than hio refor of the adminiotration and tho ldoas undorlying that reform. 
Appondix A. TRAUSCIITS OF DOCUREITS. 


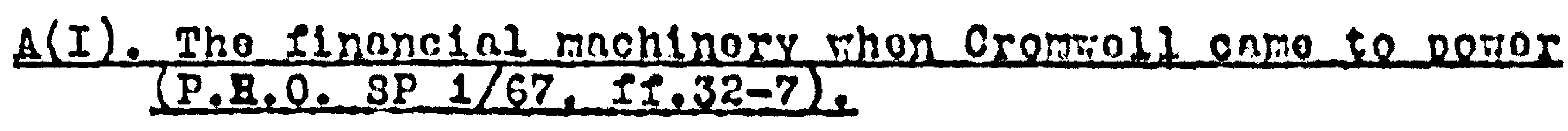

(Pagsagog botroon t...t addod by Crosmoll himooll).

I.32, a Homoriall for tho kingoo highnoo for tho rogardo of hio (ondd.) Ifinances

1.33 A Lerioriall for the Kingoo Il ghnoo, doclaring tho kymio of thinglo whorin Riolth yorolyo aoroll hlo Cortoln nouonuoo as his Casuel Rouonuos and who bo offlcore to his highnoo in that bohalf.

The thesaurer of Englondo

The Liaster of the frardes of tho lyuereyo

-

The Butlar of Englonde

The Surueyours of racacions of Busshopriches and $A B b$ Bsiog
The surueyours

Ifurat, tho yerollo Rouonuoo and proIfitoo groming of tho Kinglo Cuotureo and Suboldloo, accorptod for in hlo oxchoquero by tho custumoro of hlo portio.

Item, tho proffittco and yorol10 Rouonotro groring of bis mardoo and of thoyro Landos and Tonewontoo, accouptod boforo tho gonorall 3uruoyouro by tho laotor of tho Fardoo.

Iho Ioouoo prossittog and sumpoo of Lonoy yerolio groing to tho klas by tho surueyours of tho lelacio Lyuerolo, accouptod before his gonerall ouruoyouro.

Tho yorelio profeltoo groulas to tho king of hla Butiorago, Rocayrod and takon by tho Butlar of Englondo and accomptod bofore tho gonorall ourueyouro.

Tho yorollo profittoo and Rouonnuorioo eroing to tho king by tho ouruoyoura of tho racaclono of Bloohoprichoo 1 bbaoloo and priouro, accomptod boforo tho zonorall Suruoyourg.

The suruoyours of Tho yorollo proffltoo and Rouonuoo groring the Rostiticion yerolio to tho Iilaglo highnod for tho Roof tho temporal- otiticlon of tho Tomporaltioo of Bloohopoo ties of Busghopos Abbotis and prlouro, accomptod boforo tho abbotis and pri- conorall Suruoyouro. ours. 
The Suruoyour of the kingos rooddoo

The Clarke of the Hanaper

1.33r The Chencelor of tho duchyo of Lancastro

The Genorall Surueyouro

The Eschequer

The Exchequer
Tho Suruoyoura of tho kinglo Noddo for Fiooddo 00100 mado yorollo on thlooldo and boyondo Tront, accomptod boforo tho gonoral 3uruoyouro.

Tho Ioduon proffiton and yorollo Rouonuoo grolng to tho kine in tho offico of tho Clarko of llanapor for hlo crot soalo, for ririttos of Entoroo, Ifinoo, and othor irittos and patontoo, occompted for boforo tho gonorall suruoyouro.

Tho yorollo Iooueo Rouonuoo and proplitoo Groling to tho king by tho llocolpuouro Eonerall and particular of tho Duchio of Lancastro, accopptod boloro tho iudi tourn of hio oald Duchio.

The yorollo Ioouod prosit too and Rouanuoo Groine to tho kine by tho handoo of hio kocolpuours gonorall, partlcular, and all othor hlo officoro bolnc chargod iith hlo Landeo, bolng accoaptod bolore tho kinglo Gonerail Surucyoura; that 10 to oayo Tarmike Landoo, Sponcoro Landoo, Bucklnehama Landoo, tho Duchio of Cornorrall, tho Chasberloyn of Chootre, tho Chamborloyn of iorth and Southrialloo, and tho holo Principalito of tho oavo.

The Ifines corciarontos and rocounsaunco takon florfolctod and cocooold yorollo, Groing in the kinglo Courtoo of hls Chauncorio, tho Storrod Chambro, tho kinglo benche, and hio cortune place, obold bo stretod and accoupted for in tho oxchoquoro.

The yerello proflitos Thich oholde Erowe to tho lefne by his Exchotourg for tho proIff tes coming of Qutiarieo, [Inotrucalono] (1) and othar oxchotio of Landos tonomontos and zourabio gooddos and catalloo, sholdo bo accomptod for in tho oxchoquoro.

1. "Inotrucrions" crosood out. 
Tho Exchoquor

Tho Exchoquor

Tho Exchoquor

1.34 Tho Gonorall Surue youro

Tho Chauncolor of tho Duchy

Tho Exchoquer

Tho Exchoquor
Tho proflitton and Rouonuoo with tho profforo of hlo Jhorleflo shlch croiro vnto hio eraco of hio Countioo and floo Iformoo tol hlo Cytyoo a Tomoot yorollo acoomptod for by hio onid shorfefoo in tho Exchoquoro.

Rocounoauncoo felnoo and amorcinmonteo forfolctod and $8000001 \mathrm{~d}$ boloro hla Iuotico of 100180, Iust1000 3hovoro, Iust1000 of tho poar, Iust100n of quorum, and Iuot100 of Oyer Dotoraymor, obolde bo otrotid into tho Exchoquoro and thoro accoeptod for.

Tho yorollo proflltton groning to tho king of tho Rocounsaunceo taison and forfolotod boforo tho Thosauror Chamborlono and $\mathrm{Ba}$ rono of hio Exchoquour, of Cuotumero, Rocolpuouro, Nlnogoouro, gagoouro, Iformouro, Shoriffoo, and Exchotoura, and other ofIlcoro, accomptod in tho Exchoquoro.

Tho yorolio proffittoo sroving to tho king of Rocounoouncoo taken and forfolctod boIoro tho kingoo genorall 3uruoyouro oholdo bo Doclared and accomptod for. tand what thoy droint to at thlat

Tho yorolio proplitoo groining to tho king of Rocounsauncoo and obligaclono forfolcted, Ifines amorclamont10 $0.300301 \mathrm{~d}$ by tho kinglo Chauncolour of tho Duchlo of Lancastro Rexayming in tho oald Duchlo; and Tolde bo lesorion that thoy bo.

Obligationo for Irploymont of worchaundi803 brought into tho lloaleo, takon by Custumors of tho kinglo portoo.

Dettos Romayning rppon tho hoddod of Dynoro Cajturoro Alnogorouo (1) Gagoouro Exchotoura Shoriflio Rocolpuouro 1 formouro and othor accomptantor in tho Exchoquoro to bo oono and Doclarod. tand what yo dor at this dayot 
Tho Gonorall ouruoyouro

Tho chauncolour of tho Drachio of Lancastro

Tho Genorall gurue youro

1.347 The Generall Suruejouro

The Gonorall ouruoyouro

$\Leftrightarrow$

Tho Genorall ouruoyouro
Dottio homaynyma uppon tho hodd1o of Dyuoro partlculor nocolpuouro and othor accomptauntoo accompting boloro tho klnboo gonorall Suruoyours to bo sono and Doclared That thoy bo and rhat tho (1) aisounte to ot thlo oayo. tdor to tho kymgt

Dottoo domayning rppon tho hoddoo of Dyuoro particulor and Eonorall Rocolpuouro Bayliffoo and othor offlcoro boforo tho Chauncolour of tho Duchio of Lancaotor to bo Bone and doclarod what thoy bo and What tho (1) asounto to at thlo dayo. tdor to the Byngt

Rocounoaunced forfolctod boloro tho Cham borlon and othor tho linglo offic ofo vithin hio Countio Palantino of (2) Chootor soldo bo domaundod for is (3) oono and That thoy amounto to at tillo dayo. t807 to the kyngt

Dottoo dopondine rppon tho hoddoo of dyuoro partl culor and Conorall Rocol puouro of tho oald Countio Palontino, accomptod for and yot not pald, Foldo bo oono inat thoy asounto to at this dayo.

Rocounoaunces ffinos Ioouog and amorciaventoo forfolctod within tho principalito of Malloo, as boforo tho chamborlono of liorth and Soutlriblos and aloo within hio Chauncorto of Pombrokoohtro, Noldo bo oorlos And also tho dottos duo by any of tho accomptauntes thero to bo knorion rhat thoy bo and rhat thoy arounto to at thio dayo.

The Rocolpuoura and othor officoro of Yingio Duchie of Cornorali accomptine Lore tho genorall Suruoyoura Moldo bo anynod, inoroin it yo (4) suptoood tho klng to bo wocho dloogyrued and That dot tos thoy bo and what thoy axounto to at thio daye.

1. sic.

2. "OI" corrected Irom "and".

3. "\&" intorlinod by ocribo.

4. "yo" correctod from "rao". 
Tho Gonorall Surueyouro

Tho yorollo proplltoo grolne to tho kine of hio landoo and tonomonton within Caloo, Qulnnoo, Hamyo, Warko a Oyo, and tho Larchon of tho oamo, bocomptod boforo tho Eonorall Rocol puoura, Roldo aloo bo nono. And that dott1o do rarsayno rppon tho hoddis of tho Accomptauntoo accomptins for tho oold landoo tonomontop and othor proIfl too erorfing of tho nald landor in $\mathrm{Ca}$ 100, Qulanoo, Ilasya, Larko, Oyo, and othor tho kincoo landoo aforosald; and thot thoy arsounto to at this dayo. Thnd who bo tho dottor, so that louy might bo rado thorol 3podolyot

[tho yoroly proflyttoo eroming to tho kyat Tiso yerolio proflittoo eroiling] (1)

1.35 The Fardon \&

(2) wastoro of tho kingoo nyt

The kinger Loarnod Counsailo

1.36 The rarden and

(3) Masters of the kynges nyat"
Tho yorolio profist too croming to tho kingoo highnoo of hlo aynt within tho towro of London and othor places rithin thlo Roal=o roldo bo onquiered for and to knorse what profflttoo hath Eroron to lalo blehnoo this Six yoros pasood, rhich I thlnko do asount to a eroeto Burso of monoy.

Tho Rouonueo and yorolio profilttoo EroFine to tho kingoo biehnoo of 8tatutoo ponall, and aloo of ondoo takon rith hio highnoa or counoalio by obllgaclon, Indonturo, payment, or othorrioo, for any manor offonco or forfalcturo, Foldo bo Doclarod by abooks so that hio highnos alght be. ocortayned thorol yorolyo.

The yerkyo proffyttoo groplag to tho kymgog highnoo of hlo aynt althln tho Torro of london and othor placoo 81 th $(4)$ thio Roal=e roolde bo [0xa](5) inquoryd for and to [So] (5) knorio rhat proffyttos hatho(d) (5) Erowen to hlo highnoo thlo [ffy] (5) syx yoros pasoyd, which I thinko do soornt to A grot Suma of ionoy.

1. The tro lines cancollod in tho us.

2. 1.35 in tho hand of a difforont clork.

3. 1.36 in Cromell'o hand.

4. Sic.

5. Lettors in square brackoto crosood out. 
A(II). "Account A" a noocimon of cromold'n acceuntn

1.156 Heroaftor onouyth tho vor of tho Accompt of Thomad Cromoll Eoquiro, Aoroll of nll and ofngulor 30 moo of monoy by hym roceyrud to tho voo or ouro woot drado souoralgno lordo tho king, an of all and ofneulor paywonton by byo mado for ouro oaido soueraleno lordo and by hlo commaundozont, efromo tho floaot of oalnt ulcholl tharebangoll in tho xil11fti yoro of tho rolgno of ouro oald oouoral cono lordo tho klng vato the xrijth day of Docombro thon noxt onouyag.

\section{that 10 to oay}

Ifurnt, chargla for Arroragon of tho laot accompt of tho obid Thomas Crowmoll Eoqulro, ondld at tho oald lloaot of oaint Hicholl tharchangell Anno xxilljto Roglo lonrlcl viljui

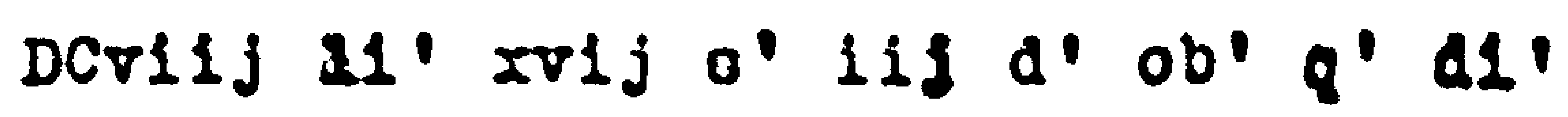

Aloo, rocoyned to tho klagoo roo by tho gald Thomao CromFell Esquire oonco tho Detorninacton of tho caldo Accompto, which was the Socundo day of Aprill inclad, into tho forooaid roijth of docombro oxclus', an by tho particulor bookos thorol oxamyid wore playnly it may apporo

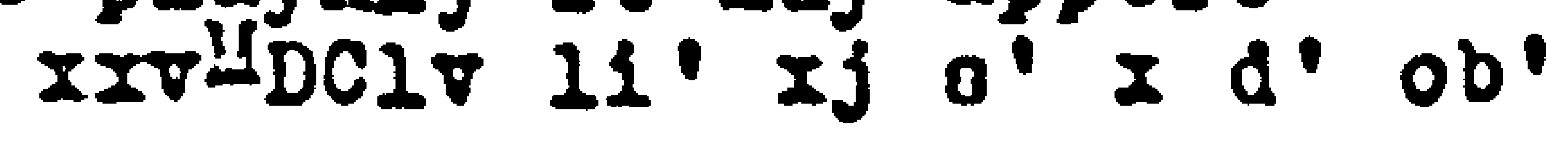

Some totell of the Rocopt rith tho Arrorageo

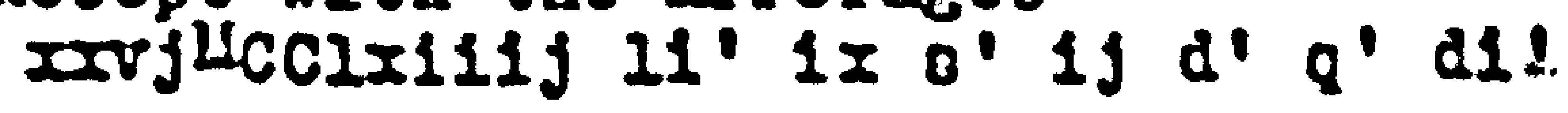

whoros

In oondry paywontes wado by tho oalde Thomas Crowrell Eoquiro, of and for tho Affalres of oure saldo oouoraleno lord tho king and by His conmoundonont, withln tho tywo aforesaid, as by tho bookoo tborol oxanynod it way moro pleynly appero

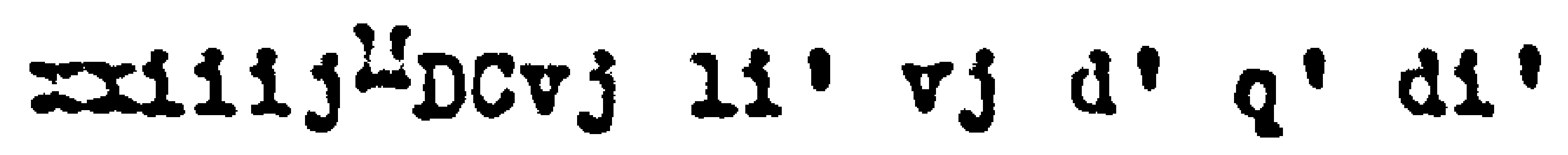

Ande co rowaynith dorro to tho klas

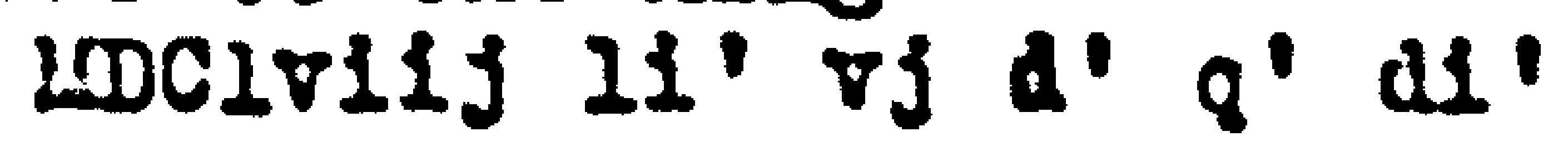

for tho whicho

1.156r Thor 18 remayning in tho Cuatody and chargo of 171111 an 
Body, soruaunto to tho oald Thomas Crommoll Eaquiro, tho oald $x \nabla i j$ th day of docoubro

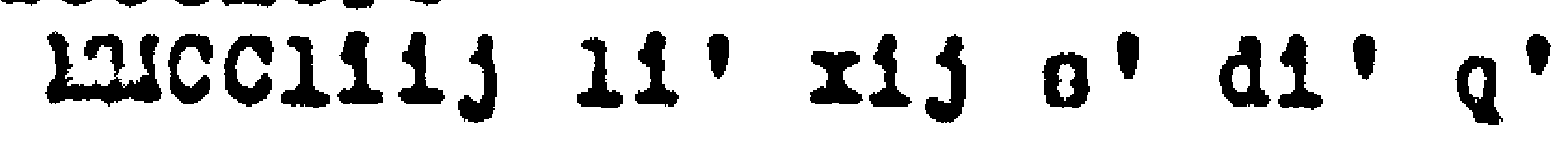

whorot

Ther 10 duo to ouro oald oouoralgno lord tho king tho forosaldo roijth day of docombro, ao io abouonaldo

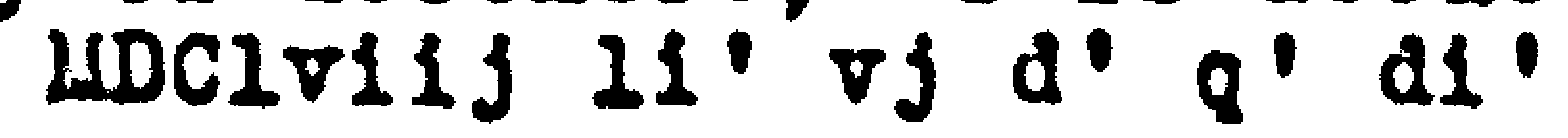

And 80 Romaynt th in tho Cuatody of tho oaldo N11110u Body in money of tho oald Thomas Cromolloo Eoquiro tho oaldo xvijth day of docombro

$$
D i 11 f^{2 x} \times \nabla 1^{\prime} x 0^{\prime} \nabla d^{\prime} \circ b^{\prime} q^{\prime}
$$

And more thor 18 lent by tho oaldo Thomao Cromoll Eoguiro of his orno wonoyo to oondry pornono, no $1 t$ apporith by the bookes thorof oxamynyd

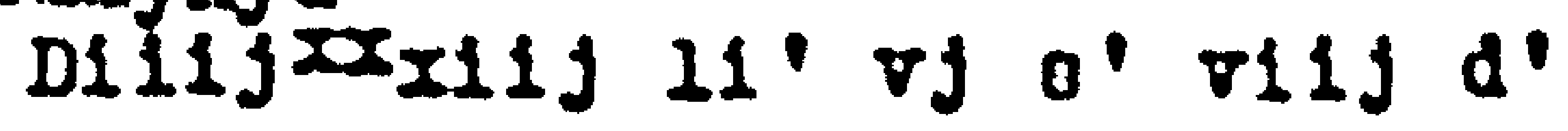

I.157 Ifymer for knyghtos Soosid by tho oold Thoma Cromoll Eoquiro to tho kinger 700 and nat paid, an 1 t apporith by tho obligaciono therol examyny, tho forooald $x \nabla 1 j$ th day of docombro

$$
\text { Lacisigxx } 11^{\prime} \nabla j 0^{\prime} \nabla 11 j d^{\prime}
$$

Ifmeo med tho (1) oald Thomao Cromoll Eaquire tith oondry persong opliftuall and tomporall to tho klngoo roo whicho be rnpalde, rith CCCC 11' Ior tho Ifyno of tho oloct Busshopp of Chootor, the oaid $281 j^{t h}$ day of Docombro

$$
x+j^{4} \mathrm{CCl} 11^{\prime} \nabla 0^{\prime} \mathrm{j} \mathrm{d}^{\prime}
$$

Heney lent to sondry poroonnes by tho kingoo comaundomont and delyuered by tho forooald Thowao Crommoll Eoquiro, within the tywo aforeoald

\section{inser $11^{\prime}$}

The some of tho opoclaltoo forfettod to the kingoo 800 by sondry porsonos for conuoying of corno, an $1 t$ opporith by obligaclons romayilas in the custody of tho oald Thowas Crompoli Esquiro the oald xrifth day of docombro

$$
100111 j^{2 x} 11^{\prime} x i 1 j 0^{\prime} 111 \mathrm{j} \mathrm{d}^{\prime}
$$


Summo of tho ffynoo and tho monoy lont with tho fortottoo Aforesald

$2811 j^{\mu} x x x j 11^{\prime} \nabla 0^{\prime} g d^{\prime}$

1.1578 (ondorood) tho accompt of ur c[rom]ro[11] 
A(III). The earlieot ouroiving warrant for payment addres30d to Crowroll (P.M.0. E $101 / 421 / 1)$.

Henry $R$

By tho king

Where 80 we vadrestande that yo hauo rocoyrod to our roo certain Somer of money of tho Rontos and Roronued of tho Inndes sumtyme apportolgnyng vato the Collogo within our Vniuergitio of Oxonford, Lato callod the Cardinall College, Wo signifyo vito you that wo haue appointed our trusty and melbiloued Maloter Milliam Treosham and Haloter William Beattog, Clerkos, to recoyre by the rayo of prost the somo of onn hundrod poundos atoriling of the aald Loney, for the payoment of tho Diottos and rater of ouche scolors, atudentes, and otipondiaryes as nor boo Redident and abldyng within tho oald Collego. Whorfore wo roll and commando you that lurthwith vpon tho olght herol, of the caid money beyag in your hander, ye not oonly delluere vnto tho oald Laiseer W1111am Tresohan and Laigter William Beattos or to olthor of theym tho oaid Some of Oon hundred poundes to thentent abourepecilied; But also that you receyvo again to our ver at tho lfoast of saint Wicholl tharchaungoll noxt comyng tho aaid Some of oon hundred poundos of the Rentes ond arrorages of suche Landes and Reuenues ag hoth been by $\nabla \theta$ Lately assigned to tho oald Collego for tho ouptentacion and mayntenmaceiol the otudentes, Scolorg, and otipondfaryes of tho' same. And these our Lettereo shalbo your gufficiont warraunt and discharge in this boholf. Yeuen vadre our 8ignet, at our Monagteryo of Cherterey,

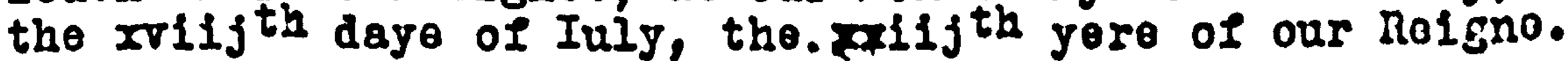

To our truaty and rolbilouod somaunt Thomas Cromitil. 


\section{A(IV) Grezwell's ordexs to the simet ossico. P. B, O. DL 43/133, II, $1-17)$.}

1.1 Adirection taken by ro, Thowao cromeroll, principall oecrotary to the klagos highneo, aeroll conoornine the atterdence of the clorkeo of tho signot as cortoyne othor thingos Ior tho ordre of tho oald off1co, Ixto dio Iully, Anno Regni Regis Honsicl octaul exrjto.

Firet, that rorothly troo of the Clorkes of tho 81enot, that is to sayo, Thomas Dorby and Filllam Pachot loyntiy as one person with Eenry Conray for his ayod in conoyderacion of hid age, one nonothe, Thowas Fryothooley and Iohn Godcalue on other Eonethe, as thoir couroov oholl from [tyme] (1) monotho to conetho com, (the oald Thomao Derby and Filliem Pacheto boeynyng thelr attordance acording to this direccion the fiyrot of duguet next onouyng), oholl give thoir Attendanco rppon the kingeo hlghneo and his gracis principall Gecrotary for tho tywo bolng; aoFell exderoring thorgollog to do tholr dution in thoxpodiction of sucho the kelnges highneo affayreo as chalbo appointede vnto ther, 28 to 000 the haule furnyechodo by them oeluos or by their Clorkeg, for tho 0880 , furthoraunce, and relif of suche porer outereo as shall reoorte to tho Corrte for Iustice, dcording to the olde ordro end custure roede hertofore in the sold oflico.

Item, thet nor of the saide Clorkos at any tyme rocoyvo receyve (2) or take, ne to his or thoir handoo, the coroy foo or Lfoos groring of any Soalo or o0aloo; but to rowyt tho recelpt of the sald floo bolonglne to tho 80 alo fully and holly to his that chalbe doputod thorrnto.

1.18 Item, that noon of tho oalde Clerkoo rithin tho court in tyme of his Lellores Eonoth intromedio hleoelf of th the ririting of any rarraunt, bill to bo olgned, or any other writing to be preoented to the lifingod Lalootio or to hlo graces roost honorable counsalll, but to loave the advauntage of all such fritingos to the other tor Clorkos that ohall then gyvo tholr attondaunce; onlos bo ohall have therunto by the linged hleghneo or hio graced princypell secretary epeciall comaundemont.

1. "tgmen" crooged out.

2. Sic. 
Item, that euery of tho Clorisos at tho ooaling of ouory warraunt, lottor, or other thing, what oo buer 1 t bo, chall entro tho same 1 th hio oon hande in to a boko to be made for that purpose; and that at ouory monothoo onde the douldent ohalbe wade and delyrorod to ouory of the Clerked his parte (1) of ouche thingoo ao haue beon passed in that monoth.

Item, [that noon ofJ (2) tho oaide Clorkes of tho signot shal not permitt or (3) ouffre any poroonne to writo in the king hauld, oonles the same bo oaruaunt to tho lordo privie seale, the principall secrotary, or to oon of tho clerkes of tho signot, or to oon of tho clerkos of tho privio Soalo.

Item, that no lettore pasoe the signot but that the oavo be firet oxamined by oon of tho clorked of tho oare, and the saide clerk, so hauing oxaminod 1t, doo write in tho neyther parte of the salde lottere for a tooticonye of his oald examination his namo.

Finally, it lo appointed that tho last dayo of ouory moneth the tro clerked phose cours ohelbe to val to the moneth foloring shall repalre to tho placo whor the principall Secretary. shalbe, or in hlo aboence to ouche othor as ehall haue the keping of the seale, and oo recoring their deuydentes as is appointed bifore; and they to entre euer their attendeunce the flrst daye of tho woneth lolowing.

1. Corrected Irom "pakto".

2. "that noon of" crooood out.

3. "or": corrected from "of". 


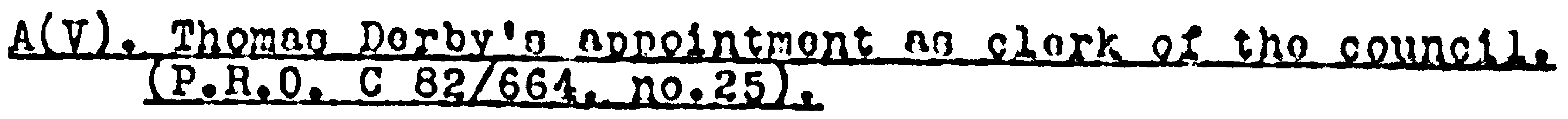

Henry tho of ght by tho graco of god KIng of England and of Ifraunco, Dofonoour of tho fol th and lord of Irland, To our truaty and right rolbilouod Counoalllour 31r Thomao Audeloy, knight, our Chouncollour, groting. To roll and comaundo you that vador our groato soalo, bolng in your koping, yo aako forth our lottoroo patontoo in manor and fourmo folowing: Honry tho olght \&c, To our truoty and right volbiloued Counoalliour olr Bryan Tuko, knight, Troao ourer of our Chambor, and to tho Ironoouror of our Chambor That horaftor ghalbo, groting. Do lato you nitt that of our graco eopociall and noro mocion and in conoldoracion of tho accoptable oerulco to vo hortoloro doon by our truoty and rolbilouod geruaunt Thomas Dorbyo, oon of tho clorkoo of your (1) olgnot, 70 haue genon and grauntod vnto him tho rowroe or office of Clarke of our Counoalll attonding vppon our poroon which Richard Eden latoly had; To hauo and to holde the oame offlce to our oald ooruaunt and hio oufflcient Doputio or his asoignoo, During bio 11f; togothor with the flee and rages of trenty poundoo by yoro, and rith all other profittoo, comoditioo, prohomynoncoo, aduantagoo and emolursonteo thorunto bolonging or in any 7100 apportoynyng, in 80 largo and anplo manor and fourso ao tho oald Richard Eden or oon $\quad$ (2) Bolous or any othor hortoforo hath enloyed and porcoirod in and for thoxerciolns of tho oald olflco; hlo oold waroo and ffoo to bo palod from tymo to tywo by tho handos of you, our Troasouror, eromo tho feast of Iydsomer last pessod, and oo quartorly During tho lif of our said soruaunt as aforo. That oxproson monclon \&c. And a transumpt of thloo our lottoroo to bo ontrid in your boke of warrauntes shalbo your ouffiont varraunt and discharge in this bohall. Youen undor our privo 30alo, at our Lanour of Gronozich, Tho xxplifth day of Ianuary Tho zxilijth yoro of our Roleno.

T. Iofforoy

(endd.) Dorby (Dolfrorod into chancory on 29 January
(533).

1. Sic.

2. Blank in LS. 


\section{Appond12 B.}

\section{BIBLIOQRAPIY.}

This biblliography contalno only manuscripto, booko, and articloo actually quoted in tho thoolo. 
B(I). Henugcript Sourcog.

\section{(a) isanuscripte at the public Rocerd ersico,}

This list gives the call number as guoted in tho thoolo with a full deacription of oach claso. Tho fleuroo in brackote aro page reforences to Guisoppl'o Guido.

C 66.......Chancery, Patont Rollo (1.3111.).

C 82....... Chancery, Marranto for tho Groat soal (1.6819.).

C 193......Chancery, Hiocollanoouo Booko, Cromn 01f1co (1.62).

DL 5...... Duchy of Lancaoter, Entry Booko of Ordoro and Docrooo

DL 12..... Dachy of Lanceator, Prify Soals and Varranto (1.333). DL 28..... Drachy of Lancastor, Varfous Accounto (1.3261.).

DL 41..... Duchy of Lancastor, Liocollanoouo Booko (1.3311.). E 36......Ezch., Troasury of Rocolpt, Wac. Booko (1.20211.). E 101......Exch., King'g Remenb., Various Accounto (1.7811.). E 135......Exch., King's Howomb., Eccloo. Documonto (1.91). E 159..... Exch., King'o Romemb., Hezoranda Rollo (1.961f.). E 163.....Exch. Eling's Romerb., Hiocollanoa of tho Exch. (1. E 164......Exch., KIng'o Rowembr., Hioc. Booko, gor100 I (1.1001.) E 323......Exch., Augrentation 0111co, Treaguror'n Accounto of the Court of Auswontations (1.161). E 336......Exch., Firot Fraito and Tontho offico, H10c. Booko

E 351..... Exch., Lord Troaguror'o Rozorb., P1Do Osf1co, Doclared Accounto (1.11811.).

E 369.....Exch.; Lord Troasuror'o Remomb., Hoc. Booko (1.1281.). 
E 404......Exch. of Reco1pt, Rarranto for Ioouod (1.1921.).

E 405..... Exch. of Rocolpt, Rollo otc. of Rocolpto and Innuoo GD 15......Elte and Dopoolto, Lanchootor Paporo (1.349). FSO 2..... Harranto for tho Prity Soal, sorton II (11.132). Req 1..... Court of Roguooto, joolso of Ordoro and Jocroos (1.271). Req 2...... Court of Roqueoto, Procoodingo (1.270). SP 1.......stato Papora, Bonry VIII (11.31.). SP 2......the same, follo volusoo (11.4). SP 3...... tho same, Liolo papers (11.4). SP 6......Thoological Tracto (1i.4). SP 60.....stato Paporo, Iroland (11.18). Fards 9... Court of Hards, Hioc. Books (1.27511.).

\section{(b) Manuscripts at tho Britinh Lusoum.}

Arundel ifs 97 (Accounts of tho Troaouror of tho Chanbor, 15371541).

Cotton uss

Caligula B.11i (otato paporo, Honry VIII).

Galba B.x (tho oamo).

Otho E.ix (paporo concorning tho navg and ohoro dofoncoo).

Thtus B.1 (otato paporo, Honry VIII).

Titus B.ir (paporo concorning financoo).

Cloopatre E.iv (paporo concorning tho wonaotorioo).

Cloopatra E.VI (paporo concorninu church alfalro). 
Egorton 482603 (H18c. hiotorical paioro, 1494-1696). Harloian us 1878 (paporo concorning cuatomo, otc.). Isrloian is 5174 (Iinancoo, Richard III - Ionry VIII). Lanodormo IIS 256 (Caosar Papora - Pranoury). Lansdorno us 168 (Caooar Paporo - Exchoquor). Lansdormo ins 171 (Caosar Papors - Trangcripto). Royel is 7.F.xiv (Gtato paporo, lionry VIII). Rojal ins ApD.89 (tho oamo). Storo ins 163 (wioc. paporo). Store is 554 (account of the troasuror of tho chambor, Lay Soppombor 1542).

Additional USS:-

4160 (miscolianoous paporo).

9835 (papero concerning tho housohold of Honry VIII). 21481 (accounto of tho troasuror of tho chambor, 1509-18). 25114 (papers, chiolly rolating to Gardinor's oabasoloo). 33376 (declaration of tho otato of tho-troasury, 1531-2). 34324 (Caesar papero).

35818 (olgnot regiotor of Sir Ralph sadlor, 1540-2). 
II. Printod Sourcon.

A cellection of Ordinanceo and Roculntione for the Govornmont of tho Roynl ilougohold, mado in aloore rolenti, ira King Edrard III to King Fillinm and Quoon linry, $30=$ cioty of Antiquar100, London 1790. $\frac{\text { Acto of tho Privy Counc1I, Od. S1r Harrfo II colao }(1540-2) \text { and }}{\text { A.I.Daoont (Irom 1542 Oniario). }}$

Erlendar ol Stato Prooro, Domantic.

$\begin{array}{ll}\cdots & \text {, Eoroign. } \\ \cdots & \text {, Sorninh. } \\ \cdots & \text {, Vonotinn. }\end{array}$

Hiotorical Lanuscripto Cosoloolon:

Sth Roport.

Hat liold Xiss.

Various Golloctions.

Lottere and Papors, Ferolm and Domootice of tho Rodgn of Henry VIII, lod. Browor, Jalrdnor, and Brod10, 18621929).

Liots of Early Chancory Procoodingo, Publlc Rocord ors1co. Lorde' Journaln.

FICOLAs sis Harrio, The Privy Puroo Eaponnon of KIng Ilonxy VIII Irom liovamber 1529 to Docombor 1532, (London, 1827).

RYIER Thomas, Foodors, (London, 1712).

SATIDERS O.T., Orders of tho High Court of Chancory, (London, 1845)

Stato Paperg of the Reim of Honry VIII, (London, 1830-52).

The Statuter of the Roalm, vol.111, (Lordon, 1817).

Trovelyan Papora, part 11, (Camdon 8oc10ty, 1863). 
III. Secondary Horko.

ALLSEBROOK N.B.J., Tho Bourt of RoQuont" in tho Rolm of El12aboth, unpubl. thoolo, London, 1936.

BALDiIIN J.F., The King'n Council in England durlng tho Judden LCor, 0xIord, 1913.

CAVEHDISH Goorge, ilfo of Tolaey, London, 1852.

COKE Sir Edrard, Tho Inotituton of the Larro of England: Part IV,

DEIAUS Robort, Filliom Imndele, rovd.ed. by R.Loroott, London, 1886.

Dictionary of National Bjesranhy, ro-100uo, 1908-9.

DIETZ F.C.2 Engligh Gorornmont Finnnce 1486-1558, Dn17. of ilinolo, studioe in the social scioncoo, ix.1920, no.3.

- The Exchoruor in Ellzaboth'n Rolgn, Sulth Collogo Studios in Hisoory, vili.2, 1923.

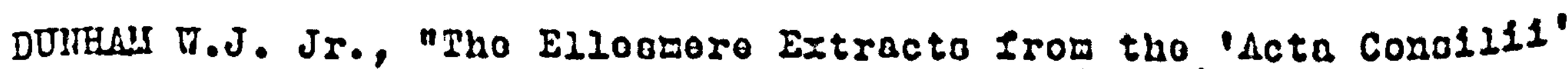
of Kine Henry VIII," E,H,R., 1Vi11(1913), PD.301-18. "Tolooy's Rulio: of tho King 'o Tholo Council," Amor.Hist.RoV:, IIII, pp.641-62.

EVArS F.H.G. (Uro.Higham), "A Hoto on tho Pro-Tudor Socrotary," Egsars in lodioval Hiotory Pronontod to T, F, Teut, (Lanchostor, 1925), pp.361-6.

Wanchostor, 1923. Tho Principal Becrotary of 8tato,

FoxE Jolun, Acta and Jonumenta, ed.Cattley, London, 1837.

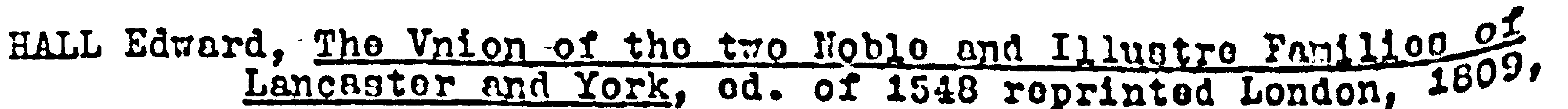
Lancastor and York, od. of 1548 roprinted London, 1809

HERBERT Lord Edrard of Chorbury, The Lifo and Rolono of Kins Henry the Elghth; London, 1672.

HIGHAII Urs.F.L.Q. (800 EVAlis F.L.Q.). 
HOLDSHORTH T.S., A Hintory of Englinh Lary, Jrd od. 1922, volo. iv, nen., 1924.

LA:BARD Villiam, Archoion, London, 1635.

LEADAM I.S., Soloct CaBoo in tho Court of Rogurontn 1497-1569, Soldon Socioty, 1898 .

LYTE Sir Honry Naxrell, Higtorlcal Noton on the Uno of tho aront Sorl in England, London, 1926.

LERRILAN R.B., Life and Lottors of Thomno Cromriold, oxsord, 1902. WOZLEY J.F., Filliam Tyndalo, S.P.C.K., London, 1937.

HETION A.P., "Tho King'o Chamber undor tho Early Tudoro," E.H.R., $2 x x i 1(1917)$, pp.348-72.

official Roturn of llambors of Parliamont, Parl.Pajors, 1878, rol.1xil, parto 1 and 2.

PICKTHORN Kennoth, Early Tudor Govornmont; V01.11: Ronry VIII, Cambridge, 1934.

POLE Reginald, Apologia ad Carolum Quintum Croonron, Eplotolarum otc. paro I, Broscia, 1744.

POLLARD A.F., "A Ohangeling Lomber of Parllamont," Bulle Inot. Hist.Resosrch, $x .20-7$.

- "Council, 8tar Chambor, and Privy Counc1l undor the Tudors," E.H.R., $2 x 271$ (1922), Pp.337-60, 516-39, Ixrvili(1923), pp.42-60. - od., "Cromirell, Thomas," Encreloprodin Brittnnica, 11th

- Factorg in Jodern Hiatory, London, 1926.

- Henry VIII, London, 1919. 1904.

Thomas Cranmer and tho Englioh Rolermation, London, - Volsey, London, 1929. 
POOLE R.L., Tho Exchoguor in tho Twoleth Contury, 0xford, 1212. READ Conyoro, yr Socrotary Folningham and tho Polley of Qunou Ellosboth, 0xfora, 1025.

REID R.R., Tho Kingin Council in tho Horth, London, 1921.

RUTHVEN J, Otray, Tho King'n Socrotary and tho gienot Q18180 in tho XV Century, Casbridgo, 1939.

SKEEL C.A.J., Tho Oounct in tho y!nrchon of raled London, 1004.

$$
\begin{aligned}
& \text { "Tho Council in tho Moot," Trana.R.M1nt,8ec., 1921, } \\
& \text { pp.62-80. }
\end{aligned}
$$

SOLERVILLE R., "Tho Duchy of Lancaotor Counc1l and Court of Duchy Chambor," Trann.Refist, Soce, 1941, pp.159-77.

STRYPE John, Ecclesiastical Horjorlain, 0xford, 1822.

THOLAS F.S., lioton on Jaterialn for the Hintory of Public Dopartmonts, London, 1846.

THORUREY I.D., "The Troaoon Logislation of Honry VIII, 1531-4," Trank.R.Hlint.80c., 1917, pp.87-123.

TouLuIl Joshua, The Hiotory of Tnunton in tho County of somornot, nor od. by J.8avago, Taunton, 1822.

TOUT T.F., Chaptorf in tho Adminintrative lliatory of lifadoral England, llaschootor, 1920-33.

VAII DYKE Paul, Renascence Portra1tg, Hor York, 1905.

Victoria County Hictory: Buckinghamohiro, Suffolk.

THITTY R.G.Hedrorth, The higtery of Iounton under the Tddern end Stuarte, unpubl.thooio, London, 1939.

FILSON J.S., The Adriniotrativo Fork of tho Lord Charcollex in the Early 17 th Contury, unpubl. thoo18, London, 1927.

TRIOTHESLEY Charloo, Chroniclo, Camdon Socioty, 1875.

FOOD Anthony à, Athones Oxonionoog, od. Bllos, London, 1813. 